\title{
ENGENHARIA DE PRODUÇÃO: PRODUTIVIDADE E COMPETITIVIDADE VOLUME X
}

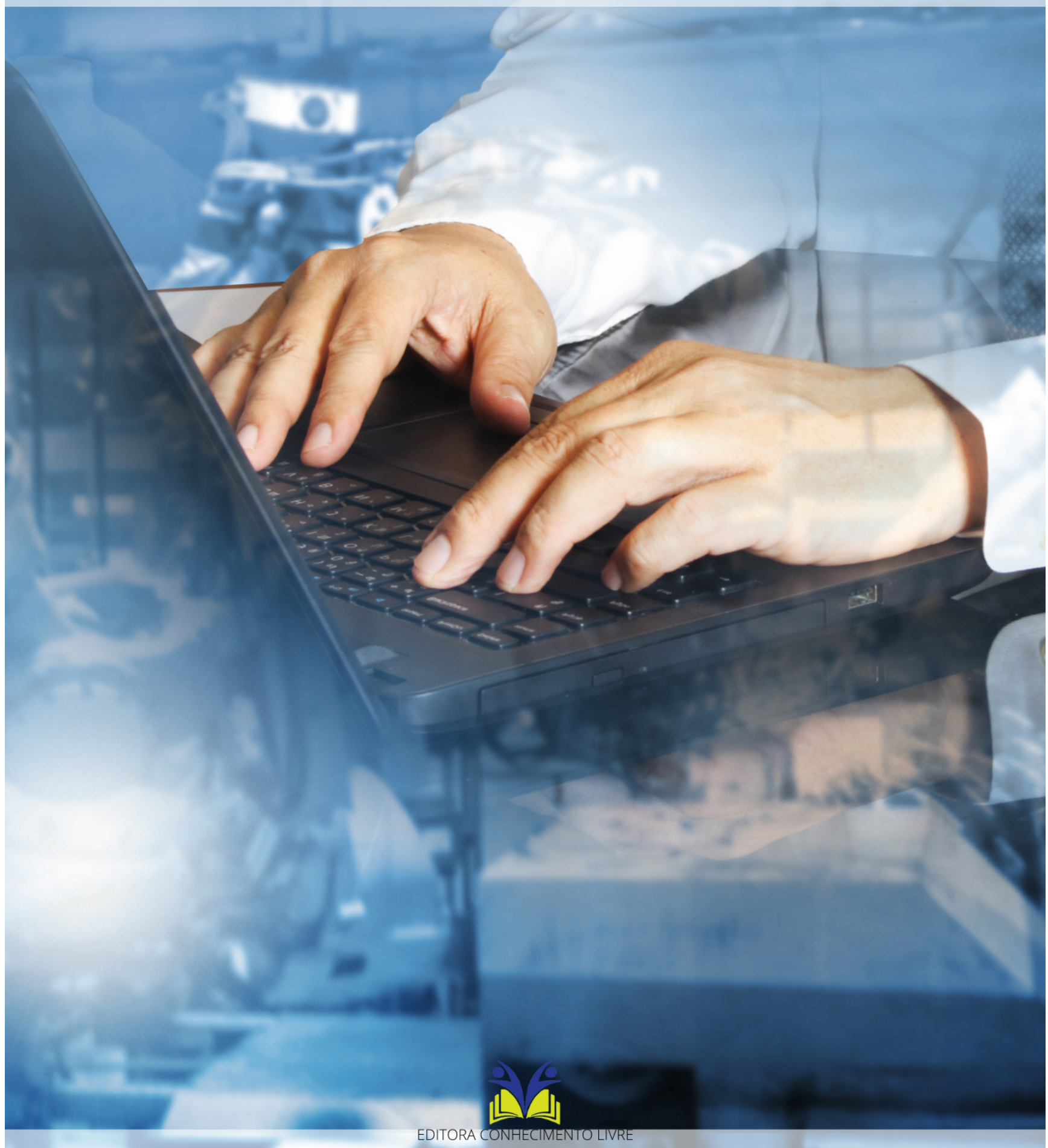


Frederico Celestino Barbosa

Engenharia de produção: produtividade e competitividade

$10^{\mathrm{a}} \mathrm{ed}$

Piracanjuba-GO

Editora Conhecimento Livre

Piracanjuba-GO 
$10^{\mathrm{a}}$ ed.

\section{Dados Internacionais de Catalogação na Publicação (CIP)}

Barbosa, Frederico Celestino
B238E Engenharia de produção: produtividade e competitividade
/ Frederico Celestino Barbosa. - Piracanjuba-GO

Editora Conhecimento Livre, 2021

190 f.: il

DOI: $10.37423 / 2021 . e d c l 284$

ISBN: 978-65-89955-32-0

Modo de acesso: World Wide Web

Incluir Bibliografia

1. projeto 2. implantação 3. operação 4. melhoria I. Barbosa, Frederico Celestino II. Título

CDU: 620

https://doi.org/10.37423/2021.edc1284

O conteúdo dos artigos e sua correção ortográfica são de responsabilidade exclusiva dos seus respectivos autores. 


\title{
EDITORA CONHECIMENTO LIVRE
}

\section{Corpo Editorial}

\author{
Dr. João Luís Ribeiro Ulhôa \\ Dra. Eyde Cristianne Saraiva-Bonatto \\ Dr. Anderson Reis de Sousa \\ MSc. Frederico Celestino Barbosa \\ MSc. Carlos Eduardo de Oliveira Gontijo
}

$\underline{\text { MSc. Plínio Ferreira Pires }}$

Editora Conhecimento Livre

Piracanjuba-GO 


\section{SUMÁRIO}

CAPÍTULO 1 6

ANÁLISE SOBRE IMPLANTAÇÃO DO SISTEMA DE MOBILIDADE NA GESTÃO DAS

OPERAÇÕES DE CONTROLE DA MANUTENÇÃO EM USINAS TERMELÉTRICAS

ANA CAROLINA SILVA DE MORAIS

GREYSIANE GONÇALVES DA SILVA

DOI 10.37423/210704425

CAPÍTULO 2

ESTUDO LOGÍSTICO DE CARGA ESPECIAL COM EXCESSO DE PESO

Alexandre Cabral da Conceição

Moisés Júlio Bernardes Cerqueira

DOI 10.37423/210704439

CAPÍTULO 3

PLANO DE BENEFÍCIOS SOCIAIS COMO FERRAMENTA DE MOTIVAÇÃO DOS

COLABORADORES DE UMA EMPRESA AUTOMOTIVA: UMA AVALIAÇÃO MULTICRITÉRIO

Aldery Silveira Júnior

Clarissa Melo Lima

Lorrane Alves Ribeiro

Lorrany Silva do Nascimento

Rafael Rabelo Nunes

DOI 10.37423/210704460

CAPÍTULO 4

INOVAÇÃO NO CONTEXTO TÊXTIL E DO VESTUÁRIO: O QUE A LITERATURA APRESENTA SOBRE O TEMA?

Marcio José Silva

Poliana da Silva Santos

DOI 10.37423/210704462

CAPÍTULO 5

AVALIAÇÃO ERGONÔMICA DO AMBIENTE CONTRUIDO: ESTUDO DO SETOR DE HEMODINÂMICA DE UM HOSPITAL UNIVERSITÁRIO À LUZ DA MEAC

Waldelourdes de Melo Souto Maior

Marilande Carvalho de Andrade Silva

Marcelo Francisco Gomes

Alaíde Farias de Almeida Filha

Vilma Maria Villarouco Santos

DOI 10.37423/210704470 
ANÁLISE DA GESTÃO DE ESTOQUES EM UMA EMPRESA GRÁFICA DIGITAL

Thaiara Oliveira da Silva

Cintia Camila de Mello Martinez

Paula Donaduzzi Rigo

Angélica Alebrant Mendes

DOI 10.37423/210704489

CAPÍTULO 7

UMA NOVA ABORDAGEM PARA INTERVENÇÕES SUSTENTÁVEIS EM PAISAGENS

HISTÓRICAS URBANAS: ENGENHARIA TERRITORIAL

Lucas Cézar Santana Ferreira

Yaeko Yamashita

Joaquim Jose Guilherme de Aragao

DOI 10.37423/210704499

CAPÍTULO 8

GESTÃO DA QUALIDADE: NORMALIZAÇÃO E CERTIFICAÇÃO

Eva Carolina Gonçalves Simões

Gabriel Borges de Lima

Giovanna de Cássia Rodrigues

Samuel Floriano Lopes de Paulo

DOI 10.37423/210704501

CAPÍTULO 9

ANÁLISE ECONÔMICO-FINANCEIRA DA SUBSTITUIÇÃO DE UM APARELHO DE

AUTOMAÇÃO EM HEMATOLOGIA EM UM LABORATÓRIO DE ANÁLISES CLÍNICAS

Bianca Michels Chaves

Denis Rasquin Rabenschlag

DOI 10.37423/210704508

CAPÍTULO 10

ANÁLISE ERGONÔMICA DE UM PRODUTO DE CONSUMO: O CASO DE UM BEBEDOURO DE MESA TIPO GELÁGUA

Marilande Carvalho de Andrade Silva

Waldelourdes de Melo Souto Maior

Alaíde Farias de Almeida Filha

Marcelo Márcio Soares

DOI 10.37423/210704523 
AVALIAÇÃO DA EFICIÊNCIA ENERGÉTICA EM EMPRESAS DO MEIO OESTE CATARINENSE Rian Lucas Franck

Cristiano Meneghini

DOI 10.37423/210704532 


\section{Capítulo 1}

\section{d.)}

ANÁLISE SOBRE IMPLANTAÇÃO DO SISTEMA DE MOBILIDADE NA GESTÃO DAS OPERAÇÕES DE CONTROLE DA MANUTENÇÃO EM USINAS TERMELÉTRICAS

ANA CAROLINA SILVA DE MORAIS

GREYSIANE GONÇALVES DA SILVA
CENTRO UNIVERSITÁRIO DO NORTEUNINORTE

CENTRO UNIVERSITÁRIO DO NORTEUNINORTE 
Resumo: A energia elétrica atualmente é fundamental para o desenvolvimento econômico e social, portanto, é de suma importância que este serviço seja prestado de modo universalizado e igualitário à sociedade. No Brasil, esse serviço vem sendo distribuído historicamente de modo desigual, desigualdade esta que se baseia na regionalidade e poder aquisitivo da população. O objetivo geral é apresentar considerações a respeito da implantação do Sistema de Mobilidade nas manutenções em usinas termelétricas, compreender o processo de inserção, identificar a importância das técnicas de manutenção corretiva, preventiva e de predição; e investigar de que modo o Sistema de Mobilidade na manutenção contribui para o aumento da confiabilidade nas informações referentes ao processo de manutenção. A metodologia utilizada para a construção deste artigo foi à pesquisa bibliográfica, onde se elaborou um levantamento de referencial teórico metodológico referente à temática em discussão para obtenção de dados já existentes, e posteriormente, analise das informações coletadas em pesquisas publicadas anteriormente, criando assim um compilado de informações de extrema importância para o conhecimento do tema aos profissionais da área. Os resultados alcançados demonstram que após a implantação do Sistema de Mobilidade na manutenção houve um aumento de $80 \%$ de produtividade; onde teve melhoras significativas nas confirmações das ordens de serviços; maior confiabilidade das informações; zero ordem impressa; redução do tempo de resposta das operações; redução de custos; maior confiabilidade nos indicadores.

Palavras chave: Usinas termelétricas, Manutenção, Confiabilidade. 


\section{INTRODUÇÃO}

A energia elétrica é o segmento de infraestrutura mais universalizado no Brasil, onde cerca de $95 \%$ da população tem acesso à energia elétrica. Contudo, mesmo com percentual de atendimento relativamente alto, o nível de atendimento varia de acordo com as características regionais do país, ou seja, regiões mais desenvolvidas econômica e socialmente, como é o caso do Sudeste e Sul do Brasil, e que também apresentam maior densidade populacional, percebem a universalização do serviço de forma mais qualitativa, enquanto as regiões Norte e Nordeste, com menor densidade populacional e quantidade elevada de pessoas com baixo poder aquisitivo não usufruem plenamente do serviço (COELHO, 2014).

Há uma tendência de aumento no numero de ligações e, consequentemente crescimento no consumo de energia elétrica no Brasil e para suprir esta demanda em evolução e evitar crises energéticas é necessária à construção de novos empreendimentos e melhoram nos sistemas de operação, controle e manutenção deste sistema.

Diante do exposto, verifica-se a importância da melhoria nos processos de manutenção em campo nas usinas termelétricas já existentes, agregando qualidade e precisão nas informações coletadas em campo e para que nos empreendimentos criados posteriormente este serviço já possa ser promovido à população de forma universalizada e igualitária em todas as regiões.

A manutenção como o conjunto de ações que permitem manter ou restabelecer um bem a um estado operacional específico ou, ainda, assegurar um serviço. Os processos de manutenção abrangem dentre outras atividades o monitoramento de maquinário. Rusticamente, o registro para controle de manutenção pode ser realizado através do preenchimento de formulários pelos técnicos responsáveis, o que dispende de muito tempo (SIQUEIRA, 2016).

A proposta deste estudo baseia-se na apresentação de um Sistema de Mobilidade que vem sendo aplicado em diversas empresas como método de simplificar o registro de manutenção, controle e monitoramento de máquinas de modo mais dinamizado e digital, que possibilite alto nível de confiabilidade nas informações e que facilite o desenvolvimento das atividades relacionadas à manutenção de maquinário.

O objetivo deste trabalho é apresentar considerações acerca do Sistema de Mobilidade nas rotinas de manutenção implantadas em usinas termelétricas brasileiras para garantir melhoria na qualidade de serviços prestados. Para tanto, seus objetivos específicos centram-se em compreender o processo de 
inserção das usinas termelétricas no Brasil; identificar a importância das técnicas de manutenção corretiva, preventiva e de predição; além de investigar de que modo o Sistema de Mobilidade na manutenção contribui para o aumento da confiabilidade nas informações referentes ao processo de manutenção das usinas termelétricas brasileiras.

\title{
2. METODOLOGIA
}

A metodologia adotada neste artigo faz referência à natureza das fontes utilizadas para a abordagem e tratamento do tema proposto. Neste sentido, o processo investigativo foi divido em duas partes, que denominamos de pré-implementação e implementação dos dados coletados.

a) Pré- implementação

Foi realizado um levantamento de referencial teórico e metodológico relacionado à temática de pesquisa. Tal levantamento baseou-se no modelo de pesquisa bibliográfica.

\begin{abstract}
A pesquisa bibliográfica é aquela que se realizam a partir do registro disponível, decorrente de pesquisas anteriores, em documentos impressos, como livros, artigos, teses, etc. Utiliza-se de dados ou categorias teóricas já trabalhados por outros pesquisadores e devidamente registrados. Os textos tornam-se fontes dos temas a serem pesquisados. O pesquisador trabalha a partir das contribuições dos autores dos estudos analíticos constantes dos textos (SEVERINO, 2007, p. 122).
\end{abstract}

Foi utilizado também o método de pesquisa documental para aprofundar o conhecimento sobre 0 tema através da busca por dados estatísticos, relatórios, dentre outras informações relevantes.

b) Implementação

Com base no material vislumbrado na fase anterior, partimos para a implementação. A última parte da estruturação metodológica deste estudo teve como objetivo a sistematização e apresentação dos resultados obtidos, portanto, realizou-se o registro do material selecionado por meio de discussão e fichamento, buscando analisar os dados/informações coletados com o intuito de desvendar os objetivos deste estudo, finalizando com a elaboração do trabalho escrito.

Este estudo de revisão bibliográfica propõe desenvolver um referencial teórico acerca da importância dos serviços de manutenção em termelétricas para garantir o melhoramento na qualidade de serviços. Tendo isso em mente, foram avaliados os índices de manutenção das UTE's, após a implantação do Sistema de Mobilidade no local, mostrando-se como sendo este recurso importante no campo de atuação da engenharia de produção da instituição numa forma de otimização de todos os recursos produtivos. 


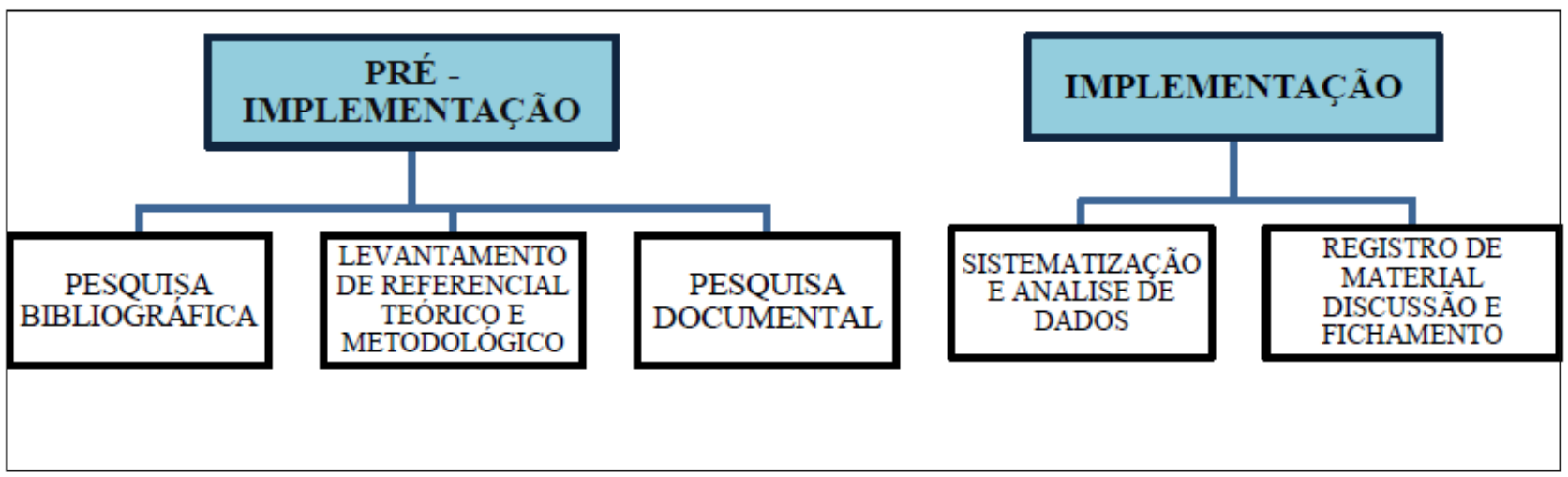

Figura 1: Metodologia utilizada para construção do artigo

\section{O SURGIMENTO DAS USINAS TERMELÉTRICAS NO BRASIL}

Historicamente, a geração de energia elétrica no Brasil difere-se de grande parte do mundo, pois é predominantemente hidráulica, devido ao largo potencial hidráulico presente no país. Foi a partir da década de 60 que a energia hidráulica ganhou impulso no país através da construção de grandes aproveitamentos hidrelétricos, com fortes investimentos estatais. Além disso, mesmo cientes do alto custo de investimento na fase de implementação da energia hidráulica, o Brasil priorizou a geração hidrelétrica como uma opção estratégica em virtude das crises do petróleo de 1973 e 1979 prioridade à geração hidrelétrica (COELHO, 2014).

Com base nos dados apresentados pela Empresa de Pesquisa Energética (EPE) no ano de 2013 nas décadas de 70, 80 e 90 houve significativa expansão da geração de energia hidroelétrica, com evolução da capacidade instalada de 13,72 GW para 24,24 GW de 1974 até 1979 (acréscimo de 76,68 \%), de 27,65 GW para 44,80 GW na década de 80 (acréscimo de 62,03\%) e de 45,56 GW para 59,00 GW (acréscimo de 29,5\%), conforme demostra a Figura 2. 


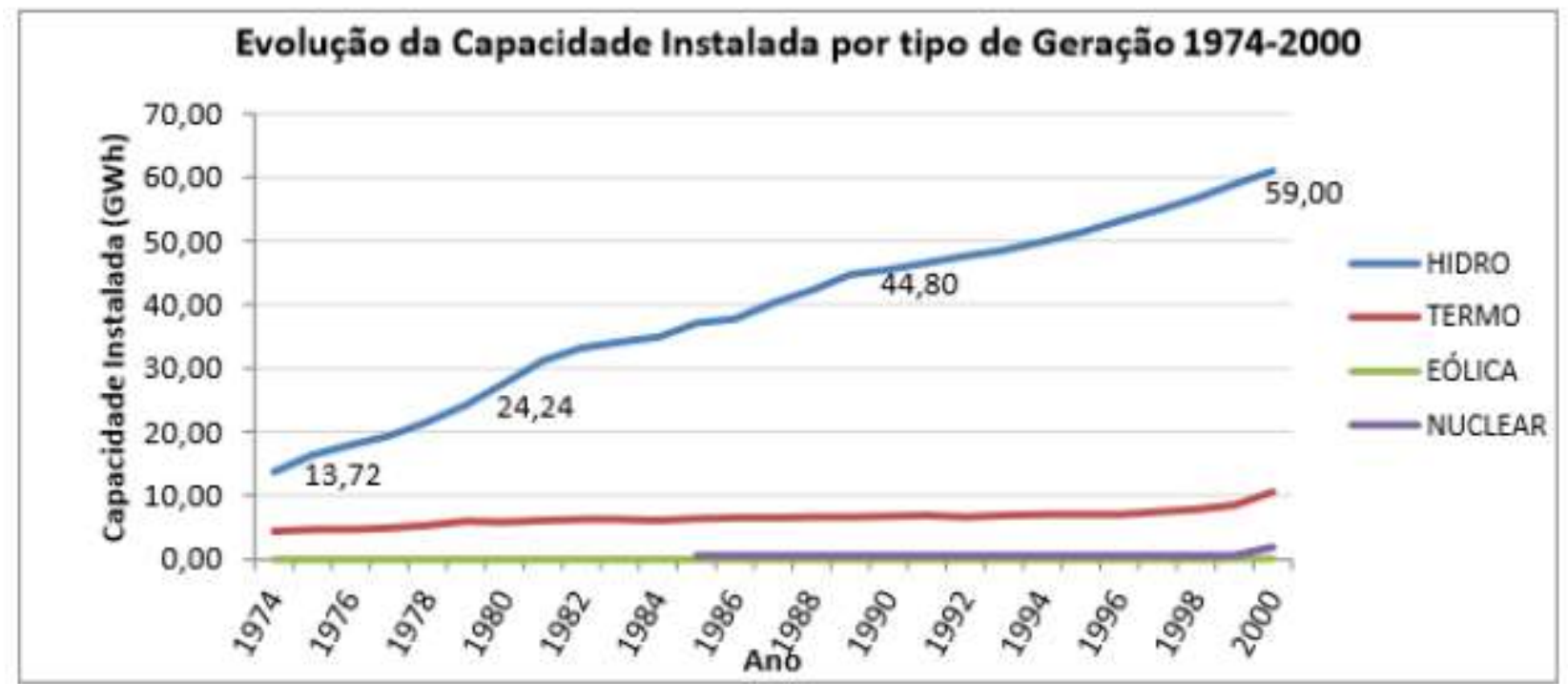

Figura 2: Evolução da capacidade instalada por tipo de geração de energia nos anos de 1974 à 2000 Percebe-se a predominancia da geração hidrolétrica em relação aos demais tipos de fontes, chegando a representar até $87,4 \%$ na década de 90 da capacidade instalada no país. Foi somente a ártir da década de 90 que a participação da energia hidráulica na matriz brasileira começou a decair, já que outras formas de geração, como no caso da termelétrica, ganharam maior visibilidade e importancia estratégica tendo em vista o cenário de crise e racionamento de energia elétrica que se instaurou no ano de 2001 (EPE, 2013).

Foi com a incidência da crise de energia elétrica de 2001, e subsequentemente expansão termelétrica que ocorreu a reforma do setor na década de 90 . Até a reforma, os investimentos e controle desse setor eram de responsabilidade do Estado que possuia o controle da geração transmissão e distribuição de energia (LEME, 2010).

A referida reforma do setor de energia elétrica acompanhou a tendência já estabelecida nos países ocidentais ainda na década de 90 propunha que o Estado tivesse maior participação na porção politica e de regulamentação do setor, transferindo as funções de investimento e operação dos empreendimentos para a iniciativa privada. Esta nova organização, de acordo com Coelho (p. 4, 2014) "tornaria o setor mais horizontal, com geradores independentes, distribuidores independentes e transmissão mista".

A partir de 1993, o mesmo autor aponta que houveram processos de reforma e promulgação de leis que eliminaram o sistema anterior de tarifas elétricas uniformizadas para todo o Brasil, fazendo com 
que os custos à população passassem a ser condizentes com os custos de geração de energia para cada concessionária.

Além disso, foi criado pela Lei no 9.478, de 6 de Agosto de 1997, o Conselho Nacional de Política Energética - CNPE e em 1999, duas portarias do Ministério de Minas Energia - MME, Portaria no 150 de 10 de Maio de 1999 e Portaria no 485 de 16 de Dezembro de 1999, criaram o Comitê Coordenador do Planejamento da Expansão dos Sistemas Elétricos - CCPE (COELHO, 2014, p. 6).

As alterações geradas por este processo podem ser percebidas na Tabela 1 que demonstra a organização do setor elétrico no final da década de 90 e início dos anos 2000.

\begin{tabular}{|c|c|}
\hline \multicolumn{2}{|c|}{ AGENTES REGULADORES E FISCALIZADORES } \\
\hline $\begin{array}{c}\text { ANEEL - Agência Nacional de } \\
\text { Energia Elétrica }\end{array}$ & $\begin{array}{l}\text { Regular e fiscalizar a produção, transmissão, } \\
\text { distribuição e comercialização de energia elétrica } \\
\text { sob as diretrizes estatais. }\end{array}$ \\
\hline $\begin{array}{l}\text { ANP - Agência Nacional do } \\
\text { Petróleo }\end{array}$ & $\begin{array}{l}\text { Regulação, contratação e fiscalização das } \\
\text { atividades econômicas da indústria de petróleo de } \\
\text { acordo com os interesses do País. }\end{array}$ \\
\hline \multicolumn{2}{|c|}{ AGENTES DE PLANEJAMENTO } \\
\hline $\begin{array}{l}\text { CNPE - Conselho Nacional de } \\
\text { Política Energética }\end{array}$ & $\begin{array}{l}\text { Formulação de políticas e diretrizes para a } \\
\text { promoção do aproveitamento racional dos } \\
\text { recursos assegurando o suprimento de insumos. }\end{array}$ \\
\hline $\begin{array}{l}\text { CCPE - Comitê Coordenador do } \\
\text { Planejamento da Expansão dos } \\
\text { Sistemas elétricos }\end{array}$ & $\begin{array}{l}\text { Planejamento da expansão do Sistema elétrico - } \\
\text { substituto do GCPS. }\end{array}$ \\
\hline \multicolumn{2}{|c|}{ AGENTES DE OPERAÇÃO E COMERCIALIZAÇÃO } \\
\hline $\begin{array}{l}\text { NOS - Operador Nacional do } \\
\text { Sistema Elétrico }\end{array}$ & $\begin{array}{l}\text { Responsável pela coordenação e controle de } \\
\text { operações das instalações de geração e } \\
\text { transmissão elétrica nos Sistemas brasileiros. }\end{array}$ \\
\hline
\end{tabular}

Tabela 1: Instituições responsáveis peo Setor Elétrico no Brasil até o ano de 2002

Fonte: COELHO, 2014

Esta nova forma organizacional refletiram imediatamente nos Estados, criando uma onde de privatizações das companhias estatais de energia elétrica e que tinham como objetivo obter o 
equilibrio do balanço de pagamentos dos governos. Com isso, Leme (2010) demonstra que a real intenção deveria ser basicamente para solucionar a crise eminente, o que não foi o caso, e mesmo com a onda de privatizações neste setor, os investimentos para o aumento da capacidade instalada ocorreram de modo desacelerado e inferior à necessidade.

O Plano Decenal 1999/2008, realizado pela Centrais Elétricas Brasileiras S.A ELETROBRÁS, indicava que haveria um déficit de energia elétrica até 2006, se fossem mantidas as taxas históricas de crescimento da demanda sempre superiores ao PIB, o incremento da população e reduções de investimentos públicos na implantação de novas fontes geradoras (XAVIER, 2004 apud COELHO, 2014, p. 7).

Foi criado o Programa Prioritário de Termeletricidade - PPT pelo Decreto Federal 3.371 de 24 de fevereiro de 2000 na tentativa de fazer frente a eminente crise e resolver o provável problema de escassez de energia elétrica e criar incentivos ao setor privado para construir usinas termoelétricas a gás natural, com suprimentos de gás a preços subsidiados pela PETROBRÁS e com financiamento especial do Banco Nacional de Desenvolvimento Econômico e Social - BNDES (EPE, 2013).

Com essa iniciativa, foram criadas uitas Usinas Termoelétricas a Gás Natural, conforme mostrado na Tabela 2. 


\begin{tabular}{|c|c|c|c|c|c|}
\hline USINA & EMPRESA & COMBUSTIVEL & UF & ESTÁGIO & POTEN(MW) \\
\hline W. Arjona & GERASUL & Gás Natural & MS & Operação & 120 \\
\hline W. Arjona (Ampl.) & GERASUL & Gás Natural & MS & Operação & 63 \\
\hline Canoas & PETROBRAS & Gás Natural & RS & Operação & 160 \\
\hline Eletrobolt & $\begin{array}{l}\text { SOC. FLUM. } \\
\text { FTDA }\end{array}$ & Gás Natural & $\mathrm{RJ}$ & Operação & 350 \\
\hline Juiz de Fora & $\begin{array}{c}\text { JUZ DE FORA } \\
\text { S/A }\end{array}$ & Gás Natural & MG & Operação & 103 \\
\hline Macaé Merchant & EL PASO & Gás Natural & RJ & Operação & 870 \\
\hline Termobahia & $\begin{array}{l}\text { TERMOBAHIA } \\
\text { LTDA }\end{array}$ & Gás Natural & $\mathrm{BA}$ & Construção & 190 \\
\hline Termoceará & $\begin{array}{l}\text { TERMOCEARA } \\
\text { LTDA }\end{array}$ & Gás Natural & $\mathrm{CE}$ & Operação & 220 \\
\hline Fafen & PETROBRAS & Gás Natural & $\mathrm{BA}$ & Operação & 54 \\
\hline Ibirité & $\begin{array}{l}\text { IBIRITERMO } \\
\text { S/A }\end{array}$ & Gás Natural & MG & Operação & 240 \\
\hline Termopernambuco & $\begin{array}{c}\text { TERMOPER } \\
\text { S/A }\end{array}$ & Gás Natural & $\mathrm{PE}$ & Construção & 500 \\
\hline Araucária & $\begin{array}{l}\text { U.G.E. ARAUC: } \\
\text { LTDA }\end{array}$ & Gás Natural & PR & Operação & 480 \\
\hline Nova Piratininga & PETROBRÁS & Gás Natural & $\mathrm{SP}$ & Construção & 400 \\
\hline Norte Fluminense & $\begin{array}{l}\text { FLUMINENSE } \\
\text { S/A }\end{array}$ & Gás Natural & $\mathrm{RJ}$ & Construção & 778 \\
\hline Três Lagoas & PETROBRÁS & Gás Natural & MG & Construção & 240 \\
\hline Camaçari & CHESF & Gás Natural & $\mathrm{BA}$ & Operação & 350 \\
\hline Termorio & $\begin{array}{c}\text { TERMORIO } \\
\text { S/A }\end{array}$ & Gás Natural & $\mathrm{RJ}$ & Construção & 1036 \\
\hline Fortaleza & CGT FORT. S/A & Gás Natural & $C E$ & Construção & 307 \\
\hline Corumbá & $\begin{array}{l}\text { TERMOCOR. } \\
\text { LTDA }\end{array}$ & Gás Natural & MS & Construção & 90 \\
\hline
\end{tabular}

Tabela 2: Usinas à Gás Natual criadas com subsidios do PPT em operação ou contrução no pepríodo de Maio de 2003. Fonte: COELHO, 2014

Apesar desta iniciativa, os investimentos demonstraram-se insuficientes e no período de 2000 e 2001 ouve um agravamento na situação devido à escassez de chuvas e baixa nos reservatórios das hidrelétricas. Mediante tal cenário, o governo foi forçado a estabelecer

diversas medidas com intuito de buscar alternativas para solucionar o problema. Em março de 2001, iniciou o programa de racionamento, criando também, em 22 de maio de 2001, a Comissão de Análise do Sistema Hidrotérmico de Energia Elétrica e, através da Medida Provisória no 2.198-5, de 24 de Agosto de 2001, instituiu-se a Câmara de Gestão da Crise de Energia (CGCE) (LEME, 2010). 
De março de 2001 a fevereiro 2002, período de racionamento, diversos mecanismos de redução de consumo foram implementados, gerando reduções significativas na demanda tanto industrial, quanto residencial. A demanda por energia elétrica foi reduzida em relação aos anos anteriores na média de $7.000 \mathrm{MWh} /$ mês, representando uma redução de $15 \%$ da demanda mensal média de 2001. Em função do racionamento, era necessário verificar as causas da crise e propor soluções que corrigissem os erros do sistema, sendo essas as atribuições da Comissão de Análise do Sistema Hidrotérmico de Energia Elétrica e da Câmara de Gestão da Crise de Energia que, por sua vez, identificou diversas causas para esse desequilíbrio (COELHO, 2014), destacam-se:

A hidrologia desfavorável precipitou uma crise que só poderia ocorrer, com a
severidade que ocorreu, devido à interveniência de outros fatores; O aumento
do consumo de energia correspondeu aos valores previstos e não teve qualquer
influência na crise de suprimento; Houve desequilíbrio entre oferta e demanda
na partida da implementação do novo modelo para o Setor; A não
implementação de obras responde por quase dois terços da energia não
aportada, sendo o fator predominante para a ocorrência da crise de
suprimento; Houve falhas no processo de transição do modelo anterior - que
identificou a necessidade de novos investimentos nos estudos de planejamento
de expansão - para o novo modelo setorial; A regulação não se caracterizou por
regras estáveis, claras e concisas de forma a criar um ambiente de credibilidade
que tivesse propiciado o investimento contemplando, ao mesmo tempo, o
interesse do consumidor; O fator principal para o insucesso das iniciativas
governamentais para amenizar a crise, em particular o PPT, foi à ineficácia da
gestão intragovernamental. Houve falhas de percepção da real gravidade do
problema e de coordenação, comunicação e controle (COELHO, 2014, p. 10-11).

O novo modelo do setor elétrico possuía falhas e limitações, implicando na necessidade de sua reavaliação e na redução no ritmo das privatizações e com isso, o CGCE, no inicio de 2002, publicou um pacote com 18 propostas de mudanças profundas em todas as áreas do setor: geração, transmissão, distribuição e comercialização da energia elétrica. A continuidade do PPT fazia parte do novo modelo, com estímulos a geração termoelétrica, em especial a geração a partir do gás natural (LEME, 2010).

Esses fatos contribuíram significativamente para uma maior diversificação da matriz de energia elétrica brasileira. Essa evolução pós 2001 fez com que a geração termoelétrica ganhasse mais importância na matriz de geração de energia elétrica no Brasil, tendo a sua participação percentual, em termos de capacidade instalada, aumentada de 14,8 \% em 2001 para 27,6\% em 2012 (EPE, 2013). Em contra partida a participação da energia hidroelétrica, historicamente predominante, sofreu redução. 
A participação das termelétricas na matriz de geração de energia elétrica brasileira aumentou consideravelmente e em dezembro de 2013 chegou a 28,71\% da capacidade brasileira. Como o sistema brasileiro é predominantemente hidroelétrico, as usinas térmicas funcionam como energia de reserva, podendo inclusive ficar grandes períodos sem gerar energia. As variações da geração dessas térmicas se dão em função de diversos fatores, que vai desde situações climáticas adversas, custo maior da energia elétrica e ainda aumento da demanda de energia, seja ele em períodos diários pontuais ou em sazonalidades maiores, como se pode verificar a Tabela 3 (COELHO, 2014).

\begin{tabular}{lllll}
\hline \multicolumn{5}{c}{ EMPREENDIMENTOS EM OPERAÇÃO } \\
\hline Tipo & Quantidade & $\begin{array}{l}\text { Potência Outorgada } \\
(\mathrm{kW})\end{array}$ & $\begin{array}{l}\text { Potência } \\
\text { Fiscalizada } \\
(\mathrm{kW})\end{array}$ & $\mathbf{0}$ \\
\hline CGH & 433 & 264.289 & 265.495 & $\mathbf{0 , 2 1}$ \\
EOL & 100 & 2.229 .565 & 2.201 .769 & $\mathbf{1 , 7 5}$ \\
PCH & 464 & 4.643 .316 & 4.604 .296 & $\mathbf{3 , 6 5}$ \\
UFV & 45 & 8.923 & 4.923 & $\mathbf{0}$ \\
UHE & 194 & 86.713 .255 & 80.860 .124 & $\mathbf{6 4 , 1}$ \\
UTE & $\mathbf{1 . 7 7 9}$ & $\mathbf{3 8 . 1 0 4 . 6 8 8}$ & $\mathbf{3 6 . 2 2 2 . 1 5 8}$ & $\mathbf{2 8 , 7 1}$ \\
UTN & 2 & 1.990 .000 & 1.990 .000 & $\mathbf{1 , 5 8}$ \\
Total & $\mathbf{3 . 0 2 5}$ & $\mathbf{1 3 3 . 9 5 4 . 0 3 6}$ & $\mathbf{1 2 6 . 1 4 8 . 7 6 5}$ & $\mathbf{1 0 0}$ \\
\hline
\end{tabular}

Tabela 3: Matriz de geração de energia - Dezembro de 2013

Fonte: COELHO, 2014

As Usinas termelétricas (UTE's), na qual a energia elétrica é produzida a partir de energia química contida em um combustível, sobretudo o gás natural, a máquina que realiza essa transformação deve ser confiável e se manter com elevada eficiência e disponibilidade. Os equipamentos capazes de realizar essa conversão são: motores a diesel e turbinas a gás. As turbinas a gás são utilizadas nas grandes termelétricas, devido a alta eficiência, confiabilidade e produtividade (SIQUEIRA, 2016).

Em termos de perspectivas futuras, o Plano Decenal de Expansão de Energia 2021, elaborado pela EPE, prevê, que até 2021, a expansão da capacidade instalada do sistema hidrotérmico brasileiro será de 65.910 MW, partindo de aproximadamente $116 \mathrm{GW}$ em dezembro de 2011 para cerca de $182 \mathrm{GW}$ no final de 2021, representando um acréscimo de 57\% na oferta de eletricidade disponível no Sistema Interligado Nacional - SIN durante esse período. 
O constante aumento do uso de turbinas a gás na geração de energia, oriunda da diversificação da matriz energética e aumento necessário da produção energética do país, inspira cada vez mais o estudo de técnicas de diagnóstico de falha, de maneira a manter as grandes disponibilidade e eficiência que esses motores apresentam. Para isso existem procedimentos de análise, dentro as quais, podemos citar: análise de desempenho, análise de óleos e partículas, análise de vibração e análise da vida útil. A união dessas técnicas possibilita uma assertividade elevada na gestão de manutenção desses equipamentos (SIQUEIRA, 2016).

\section{SISTEMA DE MOBILIDADE NAS USINAS TERMELÉTRICAS}

A Manutenção é umas das áreas que mais vem sendo desenvolvida na indústria, devido à ligação direta desta atividade com a qualidade dos serviços ofertados em qualquer instituição. Neste sentido, Siqueira (2016) aponta que é imprescindível maior conscientização da relação entre manutenção e qualidade do produto, maior pressão para se conseguir alta disponibilidade e confiabilidade da instalação, ao mesmo tempo em que se busca a redução de custos. Exigindo assim novas posturas e habilidades das pessoas envolvidas na manutenção, desde gerentes, passando pelos engenheiros, até os operadores.

Quando se fala em manutenção deve-se levar em consideração que intervenções no equipamento podem causar danos graves quando são realizadas de modo exacerbado ou incorreto, entretanto, pouca manutenção acarreta na ineficiência do sistema. Desta forma é necessário manter o equipamento com certo grau de confiabilidade, disponibilidade e eficiência.

Logo, é imprescindível que uma organização possua estudos que possibilitem ou facilitem a predição de falhas e que realizem a otimização da eficiência dos ativos, sobretudo as termelétricas, atingindo assim o mais alto nível de confiabilidade, com o menor investimento em componentes e mão - de obra. A falta de processos bem estruturados de identificação e predição de falhas é frequente nas organizações. Em consequência deste fato a empresa não consegue manter os custos de operação minimizados, resultando assim na baixa competitividade, redução da segurança do ativo e aumento do impacto ambiental. O estabelecimento de critérios e a implementação de técnicas a serem adotadas torna-se um fator primordial no desempenho e disponibilidade global dos equipamentos (Seixas, 2008).

Este artigo tratar de três tipos de manutenção: a manutenção corretiva, manutenção preventiva e manutenção preditiva. 
a) Manutenção corretiva

De acordo com Siqueira (2016) a manutenção corretiva trata-se da correção ou reparo de um equipamento para restauração de seu desempenho original, podendo ser caracterizada como uma atitude curativa e que pode ocorrer de duas formas: através do monitoramento dos parâmetros de operação e falha inesperada. O mesmo autor ressalta que este tipo de manutenção deve ser evitado, pois acarreta prejuízos na produção, podendo causar grandes danos no maquinário. No entanto, quando este tipo de manutenção é feita de modo planejado, os custos são menores e para tanto, é necessária a realização de monitoramento de parâmetros operacionais.

b) Manutenção preventiva

Este tipo de manutenção visa à correção de defeitos. De acordo com Kardec et. al. (2009) trata-se da atuação de forma a reduzir u evitar falhas ou quedas de desempenho que segue um plano elaborado previamente para manter o equipamento e suas instalações em estado adequado de produção.

c) Manutenção preditiva

Também conhecida como técnica de manutenção sob condição ou manutenção com base no estado do equipamento possibilita a garantia da qualidade de serviço, baseando-se na aplicação sistêmica de técnicas de análise por meio de supervisão centralizada ou de amostragem para redução das atividades de manutenção preventiva e corretiva não planejada. Esta forma de manutenção permite parar o maquinário no momento ideal para a manutenção e minimiza intervenções e aumenta a disponibilidade. Mostra-se como a forma mais adequada, pois reduz paradas no equipamento, o que incidiria na redução do lucro da organização (SEIXAS, 2008).

O Sistema de Mobilidade utilizado nas usinas termelétricas tem mostrado um melhoramento no registro das ações. Este Sistema de dispositivo móvel possibilita ao usuário do recurso apropriação de informações relativas ao módulo PM (plant maintenance) do Sistema SAP ${ }^{\circledR}$, funcionando como uma importante ferramenta para maximizar os resultados promovidos pelo uso do módulo PM e agregando qualidade e precisão nas informações coletadas em campo. O fluxo do Sistema pode ser verificado na Figura 3. 


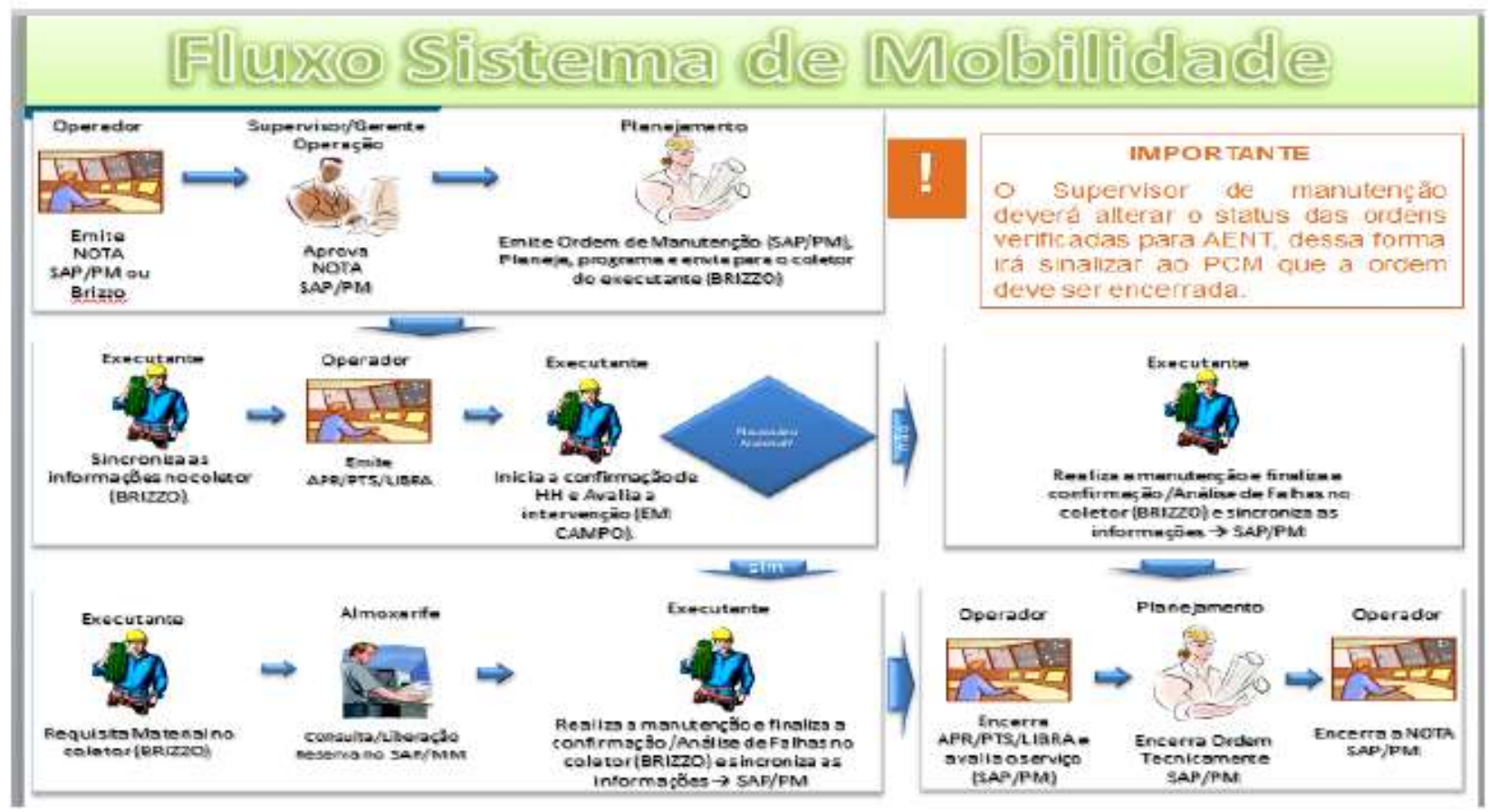

Figura 3: Fluxo do Sistema de Mobilidade aplicado nas termelétricas

Fonte: SIGGA, 2017

Por meio do cadastro de informações no sistema o operador emite uma nota de ordem ao supervisor ou gerente de operação que aprova a nota, o que possibilita uma emissão de nota de manutenção planejada ao coletor do executante no proprio sistema. O exeutante após receber a nota deve sincronizar as informações no sistema e o operador responde com a emissão de APR/PTS/LIBRA para o executante que devverá iniciar a confirmação de HH e avaliar se há necessidade de intervenção em campo, caso nao seja necessário material, o executante realiza a manutenção e finaliza confirmação, além de analisar se há falhas $n$ coletor e sincronizar as novas informações no via SAP/PM. Se for necessária a emissão de material o executante da manutenção deve requisitar material no sistema ao almoxarife, que por sua vez libra a reserva de material via SAP/PM ao executante que então poderá realizar a manutenção e confirma-la no sistema. Finalmente o operador irá encerrar APR/PTS/LIBRA e avaliar o serviço (SAP/PM).

Dentre os beneficios do uso deste Sistema Mobilidade podem ser citados:

Agilidade no atendimento de chamados; eliminação da necessidade de digitadores para entrada de dados; possibilita a captura de fotos, anexo de documentos, coordenadas GPS e asinaturas, reduz deslocamentos, aperfeiçoa tempo e mão de obra para mais tarefas ao dia; facilita o registro e consulta de dados em tablet e smartphones; aumenta a confiabilidade e precisão das informações, alem da produtividade da equipe de manutenção; permite o controle do desempenho e das atividades da equipe (SIGGA, 2017). 
A manutenção deve ser tratada como parte indispensável em uma organização e, de acordo com Siqueira (2016), quando se trata das informações quanto a este processo deve-se ter um alto grau de confiabilidade e repetibilidade são, sem sombra de dúvidas, essenciais, o modelo deve permitir a fácil verificação, para se assegurar o funcionamento correto.

\begin{tabular}{|c|c|c|c|c|c|c|c|c|c|c|c|c|c|c|c|c|c|c|}
\hline \multicolumn{19}{|c|}{ Indicadores de desempenho da Manutenção - Maio/2017 } \\
\hline \multicolumn{19}{|c|}{ Período - 01 a 31 de Maio } \\
\hline UTE & ICPM $[(x)$ & Mera & PEPMhh (\%) & Meta & BCIG (dla) & Meta & \begin{tabular}{|l|} 
PFODM $(\chi)$ \\
\end{tabular} & Mera: & CPLANR & Mera & NDISPH & Whera: & OIFM $[x]$ & Meta & BCLG-MEC & Mera & $210-1$ & Theta \\
\hline $\mathrm{xxx}$ & $82 \%$ & \multirow{2}{*}{$75 \%$} & $80 \%$ & \multirow{2}{*}{$70 \%$} & 4 & \multirow{2}{*}{21} & $62 \%$ & \multirow{2}{*}{$60 \%$} & $95 \%$ & & $87 \%$ & & $10 \%$ & \multirow{2}{*}{$x \times x$} & 4 & & 4 & \multirow{2}{*}{21} \\
\hline$x x x x$ & $85 \%$ & & $81 \%$ & & 4 & & $60 \% 6$ & & $95 \%$ & & $84 \mathrm{~K}$ & & $111 \%$ & & 4 & & 4 & \\
\hline Total BRT & $83 \%$ & 75 & $74 \%$ & 70\% & 4 & 21 & $57 \%$ & $60 \%$ & $95 \%$ & $x x x$ & $85 \%$ & $50 \%$ & 1056 & $x \mathrm{xx}$ & 4 & 21 & 4 & 21 \\
\hline
\end{tabular}

\begin{tabular}{|c|c|c|c|}
\hline ICPM & İndice de Cumprimeto dos Planos de Manutenção & PLANDISPHh & Percent de horos de manut plenej em reloção ao Hh disponive \\
\hline PEPMHh & Percentual de Eficácia dos Planos de Manutencão & OIFM & Ordens impedidas por falta de material \\
\hline BACKLOG & Registro do Passado / Acúmulo de trabal ho Pendente & BCLG MEC & Backlog acumulado Mecânica \\
\hline PRODM & Produtividade da Manutenç̃o & BCLG ELET & Backlog acumulado Elétrica e Instrumentaşa \\
\hline EXECPLANHh & líndice de Execuçẫo de Serviço Planejado & & \\
\hline
\end{tabular}

Figura 4: Indicadores de desempenho da manutenção de duas usinas Termeletricas no (AM) que já implantaram o Sistema de Mobilidade - Maio de 2017

Na Figura 4 pode-se perceber que no período de maio de 2017 os indicadores de manutenção demonstram o grande percentual de alcance das metas propostas. Este controle tornou-se possível somente após o Sistema de Mobilidade que permitiu o registro das informações de forma mais confiável, organizada e precisa. Antes da implantação do Sistema de Mobilidade os registros eram feitos manualmente de modo impreciso onde obteve despesas e aumento de custo.

\section{CONSIDERAÇÕES FINAIS}

A energia elétrica é necessidade fundamental para o crescimento e desenvolvimento social e econômico no país. Nas décadas de 70, 80 e 90 a distribuição de serviço era feita por meio de usinas hidráulicas por motivos estratégicos. Esse cenário só começou a modificar-se no fim da década de 90, principalmente com a reforma de 2001 um processo de privatização dos serviços elétricos.

As usinas termelétricas passaram a aumentar consideravelmente a partir de dezembro de 2013 e funcionam principalmente como energia reserva e diversificam a matriz energética do país, além de aumentar sua produção energética de maneira que possa manter a disponibilidade e eficiência dos serviços.

No entanto, para que a prestação deste serviço seja realizada de modo qualitativo, é necessário que as empresas prestadoras mantenham um controle da produção por meio de técnicas de manutenção. As 
UTE's que utilizam o Sistema de Mobilidade possuem um controle de manutenção baseado nos modelos de manutenção corretiva, preventiva e preditiva, controlado via sistema de gerenciamento de manutenção móvel.

Este sistema possibilita o despacho eletrônico de ordens, integração com SAP/PM, recursos móveis, redução de deslocamento, controle de desempenho das equipes, registro confiável às informações se tornam mais precisas devido aos recursos móveis que o próprio sistema disponibiliza, bem como redução de custos e mão de obra.

A implantação deste sistema tem se mostrado satisfatória nas usinas termelétricas, pois possibilita o aumento da confiabilidade nas informações acerca dos processos de manutenção, além de agilizar tais processos, o que possibilita a melhoria na prestação de serviço à sociedade. 


\section{REFERÊNCIAS}

Brasil. Decreto Federal no 3.371 de 24 de fevereiro de 2000. Institui, no âmbito do Ministério de Minas e Energia, o Programa Prioritário de Termeletricidade, e dá outras providências. Publicado no Diário Oficial da União - D.O.U. de 25.2.2000.

Brasil. Lei Federal no 8.631, de 04 de março de 1993. Dispõe sobre a fixação dos níveis das tarifas para o serviço público de energia elétrica, extingue o regime de remuneração garantida e dá outras providências. Publicado no Diário Oficial da União - D.O.U. de 29.1.1993.

Brasil. Lei no 9.427, de 26 de Dezembro de 1996. Institui a Agência Nacional de Energia Elétrica ANEEL, disciplina o regime das concessões de serviços públicos de energia elétrica e dá outras providências. Publicado no Diário Oficial da União - D.O.U. de 27.12.1996.

Brasil. Lei $n$ 0 9.478, de 6 de Agosto de 1997. Dispõe sobre a política energética nacional, as atividades relativas ao monopólio do petróleo, institui o Conselho Nacional de Política Energética e a Agência Nacional do Petróleo e dá outras providências. Publicado no Diário Oficial da União - D.O.U. de 7.8.1997.

Brasil. Lei no 9.648 de 27 de Maio de 1998. Altera dispositivos das Leis no 3.890-A, de 25 de abril de 1961, no 8.666, de 21 de junho de 1993, no 8.987, de 13 de fevereiro de 1995, no 9.074, de 7 de julho de 1995, no 9.427, de 26 de dezembro de 1996, e autoriza o Poder Executivo a promover a reestruturação da Centrais Elétricas Brasileiras - ELETROBRÁS e de suas subsidiárias e dá outras providências. Publicado no Diário Oficial da União - D.O.U. de 28.5.1998.

Brasil. Medida Provisória no 2.198-5, de 24 de Agosto de 2001. Cria e instala a Câmara de Gestão da Crise de Energia Elétrica, do Conselho de Governo, estabelece diretrizes para programas de enfrentamento da crise de energia elétrica e dá outras providências. Publicado no Diário Oficial da União - D.O.U. de 27.8.2001.

COELHO, S.O. Avaliação das Emissões atmosféricas das Principais Termelétricas Brasileiras a Gás Natural - Ano Base 2013. Universidade Federal de Juiz de Fora - Curso de Engenharia Sanitária e Ambiental - Juiz de Fora, 2014. Disponível em:

http://www.ufjf.br/engsanitariaeambiental/files/2014/02/TFC-SILAS-FINAL.pdf Aceso em: 10 de set. de 2017.

Empresa de Pesquisa Energética - EPE. Balanço Energético Nacional 2013: Ano base 2012. Empresa de Pesquisa Energética. Rio de Janeiro: EPE, 2013.

GIL, Antônio Carlos. Como elaborar projetos de pesquisa/Antonio Carlos Gil. - 6. Ed. - São Paulo: Atlas, 2010.

KARDEC, A., NASCIF, J. Manutenção: Função Estratégica. 3 ed., Rio de Janeiro: Qualtymark, 2009.

LEME, A. A. O Setor Elétrico e a América Latina: Argentina, Brasil e México em Abordagem Preliminar. Revista de Estudos e Pesquisas sobre as Américas, v. 7, no 2, Brasília, 2010.

SEIXAS, E.S. Determinação do Intervalo Ótimo para Manutenção Preventiva, Preditiva e Detectiva. Reliasoft Brasil, 2008. 
SEVERINO, Antônio Joaquim, 1941 - Metodologia do Trabalho Científico - 23 ed. ver. E atual.- São Paulo: Cortez, 2007.

SIGGA-MOBILE TECHNOLOGIES. C2017. Website: http://sigga.com.br/sigga-brizzo.php Acesso em: 9 de set. de 2017.

SIQUEIRA, H.B. Oportunidade Ótima de Manutenção em Turbina a Gás em Termelétricas. Henrique Bastos Siqueira -2016, 83 p. Disponível em: http://www.ufjf.br/mecanica/files/2016/07/TCCII.pdf . Acesso em 09 de set. de 2017. 


\section{Capítulo 2}

do:

\section{ESTUDO LOGÍSTICO DE CARGA ESPECIAL COM EXCESSO DE PESO}

Alexandre Cabral da Conceição

Moisés Júlio Bernardes Cerqueira
Fatec (Baixada Santista)

Fatec(Baixada Santista) 
Resumo:Este artigo tem o objetivo de apresentar a relevância do conhecimento documental para a execução do transporte de carga indivisível com excesso de peso. Um bom conhecimento trás a facilidade para contratação de empresas capacitadas em termos de recursos materiais e humanos para o transporte da carga em segurança e com custos reduzidos para a entrega no destino final, o conhecimento das legislações ajuda na pratica segura do transporte e para a contratação de batedores para a escolta do transporte, usar as sinalizações adequadas para este tipo de carga, as pesagens permitidas em cada via, os tipos de transportes a serem utilizados, entre outras especificações essenciais para garantir a segurança da carga, dos motoristas e de todos envolvidos na transposição da carga. Por se tratar de um assunto pouco abordado,tantos os clientes como as empresas responsáveis que prestam este serviço,da mais simples utilizados para a elaboração deste artigo foram pesquisas bibliográficas relacionadas ao assunto para melhor exemplificar carga dimensionada,quanto a mais complexa que são as superdimensionadas, como no nosso artigo aborda ,devem estar atentos aos requisitos básicos para o transporte para evitar perdas. Os métodos a abordagem apresentada.

Palavras chave: Carga indivisível, Documentação, Normas, Transporte logístico. 


\section{INTRODUÇÃO}

A carga especial é uma carga que requer maior atenção, especialmente nas competências de logística e transporte. Por definição carga especiais são aquelas que não se enquadram nas resoluções 12/98 e 68/98 do CONTRAN• neste artigo trataremos de cargas com excesso de peso.

Por este motivo a gestão logística, dos fabricantes e clientes precisam definir uma logística compatível com as necessidades e disponibilidade. O custo é um fator que vem determinando a escolha de um modal ou outro nas operações. Sendo tal evidencia indiscutível o modal rodoviário é o mais utilizado, porém é o modal que possui deficiências que precisam de reparações para se tornar um transporte mais seguro e eficaz.

Focado no transporte de carga especial é apresentado neste artigo o transporte de carga especial com excesso de peso, mais objetivamente, definições, legislação, documentos necessários e normas a serem seguidas para o transporte.

Os transportes de carga especial com excesso de peso alem de equipamentos especiais, requer conhecimentos pertinentes, conhecimento da legislação necessária e da infraestrutura disponível.

Dentro do que está sendo apresentado, tem-se por objetivo expressar a importância do conhecimento do transporte e o cumprimento das exigências em relação ao seu transporte, ao cumprimento das leis que autorizam seu transporte, alem de assegurar um transporte seguro e com a agilidade possível ao transporte e seus procedimentos requeridos.

Segundo (ABBOTT, 2011), para uma nação ser economicamente competitiva é imperativo que sua infraestrutura de transporte proveja a questão da segurança aliada à rápida e eficiente movimentação de mercadorias e de pessoas. Esta visão convergente dos especialistas é compartilhada também junto à academia.

\section{METODOLOGIA}

A metodologia adotada foi à pesquisa exploratória e qualitativa. De acordo com (Collis; Hussey, 2005) é um tipo de pesquisa cujo principal objetivo é o fornecimento de critérios para contextualizar a situação-problema enfrentada pelo pesquisador e gerar embasamento para sua compreensão. Onde a escolha deste método justifica-se pela falta de informações claras sobre a logística de transporte de carga especial. 
Para a coleta de dados foi utilizada a pesquisa bibliográfica, com informações obtidas através do site da CODESP (Companhia Docas do Estado de São Paulo, 2016), CET (Companhia de Engenharia de Trafego, 2016), bem como informações de matérias de sites de empresas especializadas no transporte de Cargas especiais que se constitui do pensamento de diversos autores sobre o assunto, a partir de material já publicado, basicamente de livros, artigos de periódicos e, atualmente, de informações disponibilizadas na internet.

Segundo (Gil, 2006), sua principal vantagem é possibilitar ao investigador a cobertura de uma gama de acontecimentos muito mais ampla do que aquela que poderia pesquisar diretamente.

Para o Estudo de caso foi realizada observação direta das operações no Porto de Santos.

\section{LOGÍSTICA}

Segundo (CSCMP, 2010.p.2), Council of Supply Chain Management Profissionals, logística é o processo de planejar, executar e controlar o fluxo e armazenagem de forma eficaz e eficiente em termos de tempo, qualidade e custos de matérias-primas, materiais em elaboração, produtos acabados e serviços, cobrindo desde o ponto de origem até o ponto de consumo, com o objetivo de atender aos requisitos do consumidor.

Inicialmente a logística foi utilizada na área militar, para definir as regiões e estratégias de guerra, de modo a combinar da forma mais eficiente, quanto a tempo e custo e com os recursos disponíveis realizar o deslocamento das tropas e supri-las com armamento, munição e alimentação durante trajeto, expondo-as o mínimo possível ao inimigo. (BOWERSOX; CLOSS, 1996).

Observa-se que muitas são as definições, propostas para a logística, sendo que cada aspecto considerado como parte integrante do conceito, historicamente já representou sua definição, sendo propostas os seguintes sinônimos para o termo logístico: distribuição física, logística de distribuição, administração de materiais, administração da cadeia de abastecimento, todos estes termos referiamse a mesma definição da administração do fluxo de produtos do ponto de origem ao ponto de consumo.

Cada vez mais precisamos entender como gestores, é que as condições do mercado, vão solicitar muitas estratégias, mas uma solução que cumpra o seu propósito que é o menor custo e curto prazo para satisfação dos clientes e na lucratividade da empresa como um todo, ganhando uma vantagem competitiva no mercado. 


\section{CARGAS ESPECIAIS}

Segundo o Conselho Nacional de Transito (Contran), cargas especiais são aquelas que não se enquadram nas resoluções 12/98 e 68/98 do CONTRAN. Neste projeto será estudado os casos de excesso de peso.

\footnotetext{
Resolução no. 12/98 regula os limites de peso e dimensões para veículos que transitem por vias terrestres.

Resolução no. 68/98 regula os requisitos de segurança necessários à circulação de combinações de veículos de carga.
}

A carga de projeto ou heavy-lift (outro nome pelo qual as cargas especiais são conhecidas) é qualquer tipo de carga pesada ou volumosa, que em razão de suas dimensões ou tonelagem, não pode ser transportada em container, exigindo, portanto equipamentos, carretas, trens, navios ou aeronaves especiais como partes e peças de usinas, transformadores, reatores, caldeiras, vagões, torres, guindastes, geradores, pás eólicas e outros equipamentos de grandes dimensões. (Silveira, 2009)

Conforme o Departamento Nacional de Infraestrutura de Transporte (DNIT), segundo a resolução no. 11/04 do órgão, carga indivisível é a carga unitária, representada por única peça estrutural ou por conjunto de peças fixadas por rebitagem, solda ou outro processo, para fins de utilização, direta como peça acabada ou ainda materiais, implementos, partes estruturais, maquina ou partes de maquinas e equipamentos, cujas dimensões e/ou peso excedam os limites fixados pelo Contran. (DNIT,2013)

Segundo o Departamento de Estradas de Rodagem (DER): “Carga indivisível é a carga constituída por uma única peça, maquina, equipamentos ou conjunto estrutural, ou ainda parte pré-montada destes elementos".

Outra definição do DER: "Carga indivisível unitizada é a carga constituída de mais de uma unidade indivisível arranjada e acondicionada de modo a possibilitar a movimentação e o transporte como uma única unidade".

No contexto geral ao se falar em cargas especiais, imagina-se os transtornos e as dificuldades, mas hoje nas bibliografias voltada aos transportes todas as informações sobre este tipo de transporte e quando aprofundado o estudo, vemos que existem normas especificas segundo o CONTRAN, DNIT, DER, para o transporte em rodovias, para evitar tais transtornos: Documentação da carga e veiculo Transportador, certas limitações a peso, altura, comprimento, veículos específicos, são alguns itens que ajudam a evitar problemas e danos, ao, meio ambiente, aos seres vivos, a carga e ao transportador caso ocorra algum problema no transporte. 


\subsection{LEGISLAÇÃO}

Conforme a Agência Nacional de Transporte Terrestre (ANTT, 2014), o transporte de cargas especiais nas rodovias está regulamentado pela lei no. 6.813, de 10 de julho e 1980, observada nas disposições no código de transito brasileiro.

A lei no. 10.233 de 5 de junho de 2001, onde constitui a esfera da ANTT, que define os padrões e técnicas relativas às operações do transporte terrestre de carga especial.

1) Portaria no. 23/1996 do DER-SP (AUTOBAN / VIA OESTE)

2) Resolução no. 11/2005 do DNIT refere-se à (NOVA DUTRA / RODOANEL)

3) Normas ABNT, com ênfase na NBR8681/2003.

\subsection{DEFINIÇÕES}

Para a concessão de autorização especial de transito (AET) para os veículos ou combinações de veículos no transporte da carga especial, a secretaria dos transportes DER define alguns termos, que não se enquadra nos limites estabelecidos pelo CONTRAN, que devem ser considerados:

1) Carga nas Partes Externas é a carga que ultrapassa os limites físicos da carroceria do veículo, quanto a sua largura ou ao seu cumprimento, exceto os equipamentos integrados a veículo especial.

2) Escolta Credenciada é o veículo destinado a acompanhamento de transportes excepcionais em peso e/ou dimensões, previstos na portaria SUP/DER-026,23/05/1985 e suas alterações, ou a que vier a sucedê-la.

3) Estudo de Viabilidade (E.V) é o estudo prévio da capacidade, portanto das obras de artes especiais (OAE'S), sendo elas obras que estão na transposição da carga especial, como pontes elevadas, viadutos, passarelas e etc.), existentes ao longo de determinado itinerário, para fins de viabilização ou não da passagem de conjunto transportador acima de determinados limites.

4) Excesso de Dimensões é a parcela das dimensões do conjunto (Comprimento, Largura, Altura e Balanço traseiro).

5) Excesso de Peso é a parcela do peso de um eixo e/ou conjunto de eixos.

6) Veículo para Acompanhamento de Operações Especiais é aquele próprio do DER (UBA) ou da concessionária da rodovia destinado ao acompanhamento das operações especiais para o transporte de cargas excepcionais. 
7) Veículo Especial é aquele constituído com características de construção especial, destinado ao transporte de carga indivisível e excedente em peso e/ou dimensão incluindo-se entre esses os reboques e semirreboques dotados de mais de três eixos com qualquer tipo de suspensão, assim como aquele dotado de equipamentos para prestação de serviços especializados, que se configurem com carga permanente, tais como: Guindastes ou assemelhado.

\subsection{DOCUMENTAÇÕES NECESSÁRIAS}

A solicitação de transporte de Carga indivisível deve conter:

1) Declaração do fabricante informando o peso do equipamento transportado de acordo com o item 1.02.01 da portaria $n=23 / 1996$, informando ainda a impossibilidade de fracionar a carga transportada;

2) Croquis do conjunto transportador carregado, atendendo ao disposto na respectiva legislação, devidamente assinado por engenheiro responsável pela montagem do equipamento, contendo:

a) CMT (Capacidade Máxima de Tração) de cada cavalo

b) Números de eixos

c) Distância entre eixos

d) Peso de cada eixo

e) Quantidade de pneumáticos de cada eixo

f) Dimensões de peça transportada

g) Dimensões do conjunto transportador

h) Indicação de pescoço hidráulico e demais dispositivos relevantes

i) Variação de altura permitida pelo equipamento utilizado

j) Raio de curvatura mínima do conjunto transportador.

3) Descrição do percurso a ser vencido, contendo:

a) Rodovia

b) $\mathrm{Km}$ inicial e $\mathrm{Km}$ final e respectiva pista de cada trecho

c) eventuais manobras a serem realizadas

4) Declaração do DER-SP de que a configuração se enquadra em seus critérios quando houver excessos de peso nos casos previstos na portaria. A portaria 23/1996 do DER-SP dispõe: 
"Os limites do item 3.02 somente poderão ser excedidos nos casos previstos no item 3.03 devendo-se neste caso apresentar ainda declaração do DER-SP afirmando que os excessos se enquadram em seus critérios".

As demais legislações não permitem tais excessos, portando deverão ser seguidos os limites previstos em cada legislação.

1) Estudo de Viabilidade nos casos previstos.

a) Fotocópias de ART recolhida pela empresa responsável

b) Descrição do conjunto transportador a ser viabilizado (veículos tratores e tracionados);

c) Descrição do percurso a ser realizado pelo transporte;

d) Vistoria das obras de arte a serem transpostas pelo conjunto transportador;

e) Analise Estrutural das Obras de Arte Transpostas;

f) Para a transposição da rodovia, deve ser previsto: acompanhamento técnico, pesagem e instrumentações;

g) Apresentação de planilha e conclusão da verificação realizada comparando a relação entre os esforços de projeto e do carregamento especial de acordo com os critérios de aprovação;

h) Emissão de laudo de acompanhamento à luz do acompanhamento realizado, dos dados referentes à pesagem, ocorrências durante a realização do transporte e da instrumentação devem finalizar e concluir a eficácia (ou não) da realização do transporte em condições adequadas.

\section{2) Condições de Transposição}

O conjunto transportador somente poderá transpor as obras:

a) Quando estas estiverem desimpedidas de demais veículos,

b) No eixo longitudinal das superestruturas, exceto indicação do projetista analisada no estudo de viabilidade;

c) Com velocidade moderada de $5 \mathrm{~km} / \mathrm{h}$ sem frear ou acelerar

d) Após a transposição do conjunto transportador, o trafego deverá ser liberado de forma lenta e gradual, de modo a evitar a ocorrência de congestionamento sobre as estruturas.

e) No caso de ventos fortes, o transporte deverá ser interrompido. 
O sistema que cuida da gestão da carga indivisível é o Sistema de Gerenciamento e Autorização Especial de Transito - SIAET.

Este é um sistema informatizado de prestação de serviços que ocorre por meio de internet, desenvolvido para solicitação, analise e expedição de Autorização Especial de Transito-AET, fornecendo-as diretamente pela internet ou agilizando o processo de cargas especiais que necessitam de estudo de viabilidade para a logística de transportes. O SIAET está disponível em todo território nacional desde 2006, um ano após sua implantação em 2005, disponível no site do DNIT.

O SIAET oferece aos usuários uma operação simples:

a) Assistência técnica e suporte operacional na manutenção dos cadastros de restrições físicas e operacionais;

b) Assistência técnica e suporte operacional na ampliação da sistemática informatizada para avaliação e emissão de autorização especial;

c) Ajustamento nas rotinas e procedimentos;

d) No sistema foi estabelecida uma classificação para cada resolução do Conselho Nacional de Trânsito, com prazo certo e valido para cada viagem, conforme artigo 101 da Lei no 9503, de 23 de setembro de 1997 do Código de Transito Brasileiro.

\section{TRANSPORTE DE ROTOR}

O transporte de cargas especiais permite a locomoção de peças que não cabem em caminhões regulares. Por este motivo necessita de autorizações especiais como AET (Autorização Especial de Transito, por apresentarem dimensões e peso acima do estabelecido pelo código de transito brasileiro, por exemplo: Carros, Pás eólicas, geradores, reatores, rotores e etc.

Estas cargas podem tirar a fluidez do transito, interferindo no sistema de trafego da cidade, o transito da carga especial é feito em horários alternativos.

Um dos problemas do transporte da carga especial é o impacto no transito urbano tendo a necessidade da realização de operações em horários específicos.

No caso dos rotores, precisam ser atendidos alguns requisitos para viabilizar a adoção desta fonte de energia e assim gerar ganhos sustentáveis na matriz energética nacional, observa-se que somente o modal rodoviário não será suficiente para atender a demanda que se apresenta com o crescimento de uso desta fonte matriz energética. 
O rotor é o elemento básico da turbina. Turbina é um equipamento construído para captar e converter energia mecânica e térmica contida em um fluido, em trabalho de eixo.

As turbinas hidráulicas são projetadas para transformar a energia hidráulica (a energia de pressão e a energia cinética) de um fluxo de água, em energia mecânica, o rotor é uma parte deste equipamento, o rotor é uma roda que conta com paletas, hélices, laminas ou cubos colocados ao redor de sua circunferência, de forma que o fluido em movimento produza ema força tangencial que impulsiona a roda, fazendo-a girar, essa energia mecânica é transferida através de um eixo para movimentar um motor que no caso é a turbina, a turbina converte em energia de uma corrente de água, vapor d'agua, ou gás, movimentando um compressor, um gerador elétrico ou uma hélice. Atualmente a maior parte da energia elétrica um dial é produzido com o uso de geradores movidos por turbinas.

A operação de rotor é registrada por um documento denominado Discharge notes (Notas de Descarga) que constitui o documento do navio no ato da carga, para a descarga da mercadoria, que sigam instruções específicas, considerando as condições locais e portuárias.

O rotor deste estudo é fabricado no Brasil, na cidade de Araraquara e transportado no modal rodoviário inicialmente até o porto de Santos onde é feito o carregamento em navio, modal aquaviário com destino a Pará, onde será desembarcada e transportada para a Usina de Belo Monte.

Para esta operação é necessário à contratação de empresa especializada em cargas individuais, que possui carretas especiais e a partir disto a carga é levada até o cliente final em horários pré- definidos.

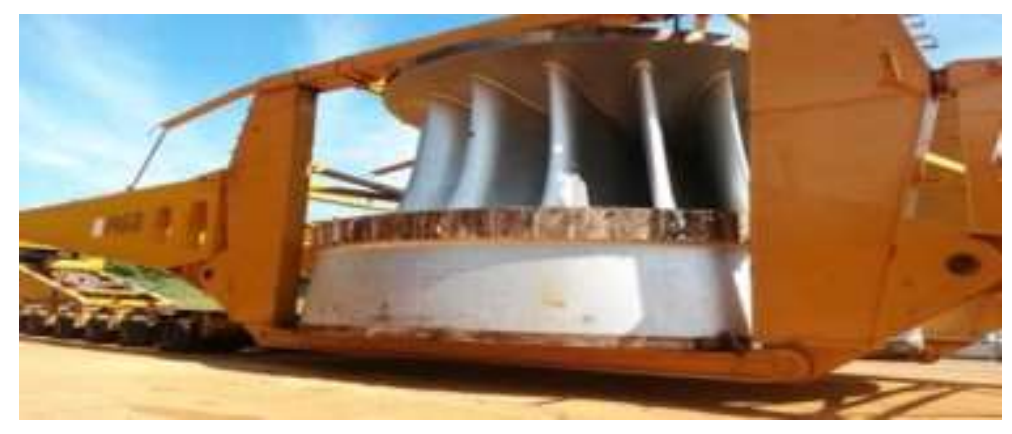

Figura 1 - Transporte de rotor

\section{VEÍCULOS E EQUIPAMENTOS NECESSÁRIOS}

Os principais tipos de veículos usados no transporte rodoviário de cargas especial são os caminhões, as carretas e as plataformas que satisfaçam as necessidades dos clientes em capacidade de carga e compatíveis com as regulamentações especificas. 
Esses veículos, ou combinações de veículos utilizados no transporte de carga indivisível devem se enquadrar nos limites de peso e dimensões definidas pela resolução no. 2264/81 do Conselho de Administração do DNIT.

As cargas consideradas especiais necessitam segundo a resolução no. 11 do DNIT capitulo 2 seções I, artigo 5:

\begin{abstract}
"O transporte de carga indivisível / projeto deverá ser efetuado em Veículos, adequados que efetuado em veículos, adequados que apresentem estruturas, estado de conservação e potência motora compatível com a força da tração a ser desenvolvida, assim como uma configuração de eixos de forma que a distribuição de pesos brutos por eixo não exceda os limites máximos permitidos nesta resolução, observada rigorosamente às especificações do fabricante e ou de órgão certificador competente reconhecido pelo INMETRO (Instituto Nacional de Metrologia)."
\end{abstract}

\title{
6. SINALIZAÇÕES DOS VEÍCULOS EM GERAL
}

Os veículos, combinações de veículos ou veículos especiais, cujas dimensões com ou sem carga que excedam os limites estabelecidos para transito normal, serão sinalizados com placas especiais de advertência. Existem três modelos diferentes.

a) Placa de Sinalização para caso de largura excedente;

b) Placa de Sinalização Traseira para o caso de Comprimento Excedente;

c) Placa de Sinalização Traseira para os casos de largura e comprimento;

As placas dever ser metálicas e revestidas com película refletiva, com faixas na largura de $15 \mathrm{~cm}$ medidas na horizontal, inclinadas de 45 graus da direita para a esquerda e de cima para baixo, nas cores pretas e laranja, tendo ao centro retângulo de dois $\mathrm{cm}$ por $25 \mathrm{~cm}$, ou $1 \mathrm{~m}$ por $50 \mathrm{~cm}$, na cor branca com inscrições em letras e números na cor preta, de $10 \mathrm{~m}$ e $15 \mathrm{~cm}$ de altura.

O Conselho Nacional de Trânsito (CONTRAN), no uso da competência que lhe confere o artigo 12, inciso I, da lei no 9.503, de 23 de setembro de 1997, que instituiu o Código de Trânsito Brasileiro e nos termos do disposto no Decreto no 4.711, de 29 de maio de 2003, que trata da coordenação do Sistema Nacional de Trânsito (SNT);

Considerando o disposto nos artigos 99, 101, 231 incisos IV, V, VI VII e X, 237 e 327 do Código de Trânsito Brasileiro (CTB) e no artigo 30 da Convenção sobre Trânsito Viário, promulgada pelo Decreto no 86.714, de 10 de dezembro de 1981, da qual o Brasil é signatário, considera que os veículos com 
dimensões excedentes aos limites fixados pelo CONTRAN para circularem em via pública devem possuir sinalização especial de advertência.

\section{O PORTO DE SANTOS}

O porto de Santos tem uma extensão de cais de 15.960 metros e área útil total de 7,8 milhões de metros quadrados, conta com 55 terminais marítimos e retro portuário de 65 berços de atracação dos quais 14 são de terminais privados. Da totalidade 10 destina-se para carga geral e 2 de multiuso (Suco cítrico a granel, roll-on / roll-off e container).

O porto de Santos vem sofrendo transformação para a melhoria continua, para o escoamento das cargas por ele embarcado/desembarcado. O terminal de carga geral na sua maior parte encontra-se instalados na Alamoa e Saboó facilitando a entrada/saída de cargas superdimensionada.

Através de convenio firmado entre o governo do Estado de São Paulo e a Codesp tendo como intervenientes a Prefeitura de Santos, a SEP/PR, a DERSA desenvolvimento Rodoviário S.A, vem desenvolvendo um conjunto de projetos viários, estes projetos contempla a região de acesso ao porto e a cidade de Santos, desde o casqueiro até a nossa Senhora de Fátima, compostos por viadutos de acesso e a saída da via Anchieta, bem como a readequação de traçados da própria via Anchieta e suas marginais. Essas intervenções trarão direta e indiretamente, benefícios ao porto, eliminando-se, por exemplo, o cruzamento em nível dessa via com a Avenida Martins fontes.

\section{A CARGA ESPECIAL NO PORTO DE SANTOS}

Para o transporte da carga especial, este é o ponto crítico na entrada do porto de Santos, uma vez que as vias são sinuosas, e em área Urbana, no que diz respeito à legislação de transito na cidade de Santos referente à entrada ou saída de cargas superdimensionadas é regulada pelo decreto no. 6.987 de 08 de dezembro de 2014.

A maior preocupação consiste na entrada da cidade de Santos devido aos cruzamentos com vias de acesso da via Anchieta com as vias da área urbana que interligam as cidades de São Vicente e Cubatão. Para a operação a estrada é fechada a outros veículos, a operação de transporte nesta estrada deverá ser realizada entre os horários de 00h00min e 05h00min horas, que constitui o horário de menor movimento nesta estrada, após chegar a Santos as carretas seguem para o porto, onde é feita a descarga e carregamento em navio. 
Neste tramite envolve as autoridades relativas ao transporte e fiscalização do porto Como a Guarda Portuária, CET, para o acompanhamento com comboio até o berço de embarque. No embarque da carga são utilizados alguns equipamentos que podem ser fixos, ou móveis, como Guindaste, Portainer, Pranchas e Mafi, além dos trabalhadores solicitados ao OGMO (Órgão Gestor de Mão de Obra) e ao Sindicato dos Estivadores, como uma operação complexa necessita-se de uma quantidade de 15 trabalhadores para a operação ou manobras da carga para o embarque/descarga do navio, são também utilizados os funcionários dos terminais portuários, para a realização deste embarque /descarga.

Utilizam-se muitos recursos como, por exemplo: Cabos de aço, Fitas de tecidos lonado, Cordas, correntes, cada um com suas finalidades para embarque em navios Cargueiros, nos casos de embarques em navios roll-on/roll-off usa-se as pranchas e as maquinas Mafi.

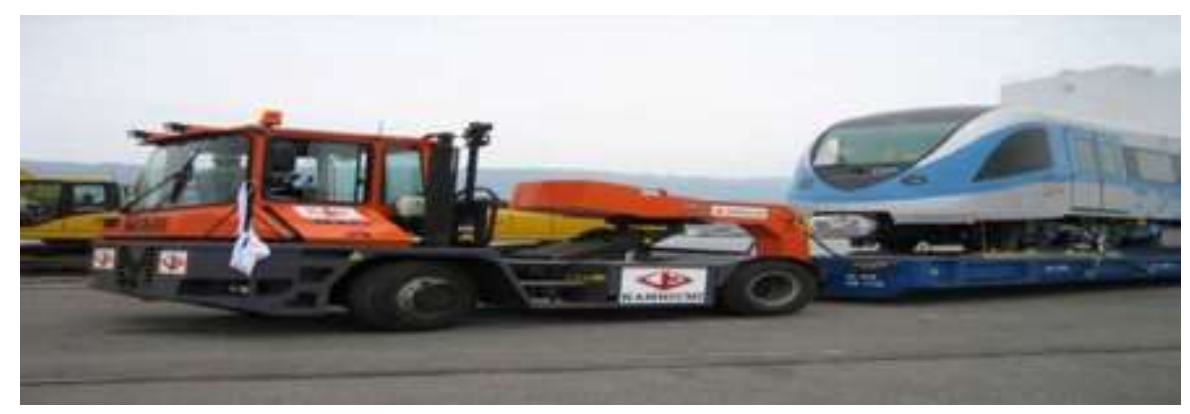

Figura 10 - Veículo tracionado Mafi e Prancha

\section{CONCLUSÃO}

Com a crescente demanda no seguimento de transporte de cargas especiais conclui-se que é fundamental o conhecimento do processo logístico e o conhecimento da legislação vigente, relacionado a esta categoria de transporte. Observa-se que no caso das cargas indivisíveis a logística precisa considerar os recursos e o conjunto de elementos que caracterizam o transporte deste tipo de carga especifica, controlando o tempo e custo, que devem estar embasados nas minuciosas informações a respeito da carga a se transportar.

Foram adotadas neste projeto as teorias pertinentes à logística, logística de transporte de cargas indivisíveis, cargas de projeto e a abordagem da sustentabilidade e uma introdução sobre a fonte de energia hidrelétrica com os aspectos relevantes, para o estudo da logística realizada no transporte de logística de projeto. Além de minimizar os impactos causados em transito urbano, a gestão logística 
no transporte de carga especial, mostrou-se de extrema importância nas análises de transporte diminuindo o tempo que influi negativamente, o custo de operação.

Outra relevância são os órgãos reguladores e os equipamentos de movimentação para que possam ser viabilizadas as operações em conformidade com as legislações e a logística estabelecida em relação ao transporte da carga. Além de todo o conhecimento documental para a efetivação do transporte, constatou-se o empenho do governo Federal, governo Estadual e governo Municipal em manter o porto de Santos, dentre os maiores portos da América Latina, para dar escoamento com maior praticidade e seguro.

É relevante no processo o uso de tecnologia em equipamentos de movimentação, como os guindastes e caminhões, a importância do SIAET é pela emissão da AET para que possam ser viabilizadas as operações em conformidade com as legislações e desta forma a logística possa ser estabelecida em relação às necessidades especiais do transporte e com isso possa evoluir para ampliação devido à demanda, a exemplo o rotor (parte estrutural de turbinas usadas em usinas hidrelétricas que são as mais usadas em geração de energia) 


\section{REFERÊNCIAS}

ABBOTT, Paul Scott, Infrastructure - A Priority for Future Competitiveness, AAPA Seaports Magazine, 2011, disponível em:

<http://www.aapa- ports.org/Publications/SeaportsDetail.cfm?ltemNumber=18152\#seaportsarticle6 $>$ Acesso em 12 mar.2016;

ANTT. 2016. Disponível em: < http://www.antt.gov.br/ > Acesso em 21 mar.2016;

CAMPOS, Luís; RISSARDO, ANTONIO R. Tipos de Transportes Especiais de Carga. Disponível em: < http://www.cetsp.com.br/media/20533/nt114.pdf> Acesso em 02 mar.2016;

CET SANTOS. 2016. Disponível em:< http://www.cetsantos.com.br/ > Acesso em 26 mar.2016;

CODESP. 2016. Disponível em: < http://www.portodesantos.com.br/tarifasDoPorto.php > Acesso em: 25 mar.2016;

CONTRAN Resolução n‥ 484 de 07 de maio de 2014 Altera a Resolução CONTRAN no 168 de 14 de dezembro de 2004, que estabelece normas e procedimentos para a formação de condutores de veículos automotores e elétricos, disponível em:

< http://www.denatran.gov.br/download/Resolucoes/Resolucao4842014.pdf > Acesso em: 16 mar. 2016;

CONTRAN. Conselho Nacional de Transito. Diretoria Executiva Resolução 520, de 29 de janeiro de 2015, estabelece os requisitos mínimos, Dimensões de Carga Superiores aos limites, disponível em: < http://www.denatran.gov.br/download/Resolucoes/Resolucao5202015.pdf>Acesso em 07 mar.2016;

COUNCIL OF SUPPLY CHAIN MANAGEMENT PROFESSIONALS. Disponível em: < http://cscmp.org/

> Acesso em: 24 mar.2016;

DER Secretária dos Transportes Departamento de Estradas de Rodagem, Superintendência, Norma para concessão de Autorização Especial de Transito para veículos ou combinação de veículos. Disponível em:

< http://200.144.30.104/der/portarias/webportarias/Anexo/029-10-1.PDF> Acesso em 15 mar.2016;

DNIT. Autorização especial de transito - AET. Disponível em:

< http://www.dnit.gov.br/rodovias/operacoes- rodoviarias/sistema-de-gere. -Espec. - transito-Aet. > Acesso em 18 mar.2016;

DNIT. Departamento Nacional de Infraestrutura de Transporte. Diretoria Executiva Resolução №. 11; publicada no D.O. U em 25 de outubro de 2004, retificada em 04/01/2005 e 16/06/2005. Disponível em: < http://www1.dnit.gov.br/aplweb/sis_siaet/download/resolucao11-04-retificada_DNIT.pdf > Acesso em 07 mar.2016; 
FILHO, Armando Oscar Cabana. Logística: Novos Modelos. 2. Ed Rio de Janeiro; Qualitymark, 2001. Disponível em:

<https://books.google.com.br/books?id=Ba2MgcYAdSoC\&pg=PA242\&dq=FILHO,+Armando+Oscar+C avanha.

+Log\%C3\%ADstica:+Novos+Modelos.+2.+ed.+Rio+de+Janeiro:+Qualitymark,+2001;\&hl=ptBR\&sa $=X \& v e d=0 a h U K E w j D m P v \_2 f P L A h U K G J A K H c 0 g D v c Q 6 A E I N T A A \# v=$ onepage \&q=FILHO\%2C\%20 Armando\%20Oscar\%20Cavanha.\%20Log\%C3\%ADstica\%3A\%20Novos\%20Modelos.\%202.\%20ed.\%20 Rio\% 20de\%20Janeiro\%3A\%20Qualitymark\%2C\%202001\%3B\&f=false > Acesso em 23 mar.2016;

FLANA O que é carga de projeto ou indivisível ou especial. Disponível em:

< http://www.flana.com.br/index. php?option=com_content\&view=article\&id=78: > Acesso em 09 mar.2016;

FLANA.Definição de Carga de Projeto Indivisível ou Especial.Disponível em:

<http://www.flana.com.br/index.php?option=com_content\&view=article\&id=78:0-que-e-carga-deprojeto-ou-indivisivel-ou-especial-ou-excepcional-ou excedente\&catid=1:noticias\&ltemid=13>Acesso em 03 mar.2016;

GUIA DO TRC Roteirizarão. Disponível em:< http://www.guiadotrc.com.br/logis/rotograma.asp > Acesso em 12 mar.2016;

GUIA DO TRC. Como Fazer Dimensionamento Correto de Veículos para Transporte de Cargas Especiais.

Disponível em:< http://www.guiadotrc.com.br/noticias/noticiaid.asp?id=29602> Acesso em 01 mar.2016;

MARTINS, Ricardo Silveira; CAIXETA-FILHO, José Vicente (org.). Gestão Logística do Transporte de Cargas. São Paulo: Atlas, 2007, Disponível em:

<https://books.google.com.br/books?id=Lf1EbDKLKNwC\&pg=PA157\&dq=MARTINS,+Ricardo+Silveira ;+CAIXETAFILHO,+Jos\%C3\%A9+Vicente+(org.).+Gest\%C3\%A3o+Log\%C3\%ADstica+do+Transporte+de+ Cargas.+S\%C3\%A3o+Paulo:+Atlas, $+2007 \&$ hl=ptBR\&sa=X\&ved=0ahUKEwig7p6y2_PLAhXGGJAKHfPHC yMQ6AEINDAA\#v=onepage\&q=MARTINS\%2C\%20Ricardo\%20Silveira\%3B\%20CAIXETAFILHO\%2C\%20J os\%C3\%A9\%20Vicente\%20(org.).\%20Gest\%C3\%A30\%20Log\%C3\%ADstica\%20do\%20Transporte\%20d e\%20Cargas.\%20S\%C3\%A30\%20Paulo\%3A\%20Atlas\%2C\%202007\&f=false > Acesso em 21 mar.2016;

SAET Serviço de Autorização Especial de Transito. Disponível em:

< http://www.derba.ba.gov.br/portal/servaet> Acesso em 07 mar. 2016;

SANTOS, Josival Novaes dos. Evolução Logística no Brasil. 2007. Disponível em:

< http://www.administradores.com.br/artigos/marketing/evolucao-logistica-no-brasil/13574/ > Acesso em 21 mar.2016; 
SILVA, Renata; KARKOTLI, Gilson (Org.). Manual de metodologia científica do USJ 2011-1. São José: Centro Universitário Municipal de São José - USJ, mar. 2011. Disponível em: < http://usj.edu.br/wpcontent/uploads/2015/04/Manual_Metodologia_USJ_MAR_2011_1.pdf > Acesso em 11 mar.2016;

TRANSPORTE PESADO O Transporte de Cargas Indivisíveis. Disponível em:

< http://www.transportepesado.com.br/transporte-de-carga-indivisiveis/ > Acesso em 01 mar.2016; 


\section{Capítulo 3}

\section{do) \\ PLANO DE BENEFÍCIOS SOCIAIS COMO FERRAMENTA DE MOTIVAÇÃO DOS COLABORADORES DE UMA EMPRESA AUTOMOTIVA: UMA AVALIAÇÃO MULTICRITÉRIO}

Aldery Silveira Júnior

Clarissa Melo Lima

Lorrane Alves Ribeiro

Lorrany Silva do Nascimento

Rafael Rabelo Nunes
Universidade de Brasília

Universidade de Brasília

Universidade de Brasília

Universidade de Brasília

Universidade de Brasília 
Resumo: O advento da globalização proporcionou a criação de fatores de negociação com foco no capital humano, o qual consiste em um dos principais recursos empresariais para elevar o potencial competitivo. A criação do plano de benefícios sociais possibilitou a implementação de ações estratégicas no ambiente organizacional e maior qualidade de vida no trabalho. $O$ trabalho desenvolvido teve por objetivo realizar uma avaliação multicritério do plano de benefícios sociais de uma empresa automotiva enquanto ferramenta de motivação, na percepção de seus colaboradores. Para tanto, desenvolveu-se um modelo de avaliação pautado na metodologia multicritério de apoio à decisão (MCDA), que norteou a pesquisa de campo e a tabulação e análise dos dados. Os dados foram tratados pelo software Hiview3. Após a tabulação e aferição dos resultados, testou-se a robustez do modelo por meio de análise de sensibilidade. A pesquisa constatou que os colaboradores da empresa analisada, de modo geral, estão satisfeitos com os benefícios que lhes são oferecidos, contudo, existem melhorias que devem ser desenvolvidas e aplicadas.

Palavras-chave: plano de benefícios sociais, ambiente organizacional, metodologia multicritério de apoio à decisão, concessionária automotiva. 


\section{INTRODUÇÃO}

O avanço da globalização e as constantes mudanças ocorridas no setor automobilístico, as organizações desse segmento tendem a criarem estratégias para reterem seus colaboradores, a partir do incremento da melhoria da qualidade de vida no trabalho, de modo que a remuneração salarial passa a não ser a única compensação ofertada, mas também os serviços e benefícios sociais, que geram vantagens para a organização e para os colaboradores.

Com o intuito de humanizar as relações de trabalho, os gestores devem programar uma visão sistêmica quanto ao diferencial competitivo que está vinculado às pessoas. Deve-se traçar o perfil dos colaboradores, compreender suas necessidades e demandas específicas, de forma a propiciar um ambiente favorável para proporcionar a motivação dos colaboradores, interferindo diretamente no comportamento humano nas organizações.

Percebe-se que os colaboradores passam a ter um maior nível de desempenho dentro de suas atividades quando ocorre a valorização do capital humano. Com a oferta de condições adequadas que auxiliem no alinhamento dos objetivos pessoais e profissionais com os objetivos organizacionais, possibilita-se a eficácia no reconhecimento do potencial de cada colaborador.

Ao implementar um plano de benefícios sociais se tem por objetivo complementar o salário fixo, atender as necessidades específicas dos colaboradores e da organização e, dessa forma, impactar no desenvolvimento operacional. Sendo de fundamental importância analisar o nível de satisfação dos colaboradores, pois a inserção de um plano de benefícios sociais apresenta-se como uma forma estratégica de desenvolvimento, remuneração e capacitação.

Dentro deste contexto, o presente trabalho tem por objetivo realizar a avaliação do plano de benefícios sociais de uma empresa do setor automotivo, como ferramenta de motivação dos colaboradores. Para tanto, foi utilizada a metodologia multicritério de apoio à decisão (MCDA), com a construção de um modelo de avaliação desenvolvido especificamente para essa finalidade. Definiu-se o problema, identificou- se os limites da análise e demais fatores envolvidos no processo, de modo a possibilitar a constatação do grau de satisfação dos colaboradores da empresa com o plano de benefícios, bem como a identificação da ocorrência de problemas, culminando com a apresentação de alternativas para melhorar a concessão de benefícios e mitigar possíveis níveis de insatisfação e desmotivação. 
O trabalho está estruturado em cinco itens: introdução, com uma sucinta descrição do tema da pesquisa; referencial teórico, abordando os principais temas que embasaram teoricamente a pesquisa; metodologia de pesquisa, com enfoque para o modelo multicritério desenvolvido para o tratamento e análise dos dados da pesquisa; análise dos resultados, onde são apresentados os dados resultantes da pesquisa e as respectivas analises; por fim, as considerações finais resultantes da pesquisa aplicada.

\section{REFERENCIAL TEÓRICO}

Abordar-se-á, de forma an passant, sobre os seguintes tópicos: Plano de benefícios sociais; Responsabilidade social corporativa; Motivação no ambiente de trabalho; e Metodologia multicritério de apoio à decisão.

\subsection{PLANO DE BENEFÍCIOS SOCIAIS}

Mediante a gradativa conscientização com a responsabilidade social por parte do ramo empresarial, as organizações passaram a aderir aos planos de benefícios sociais como forma de complementar os salários, alinhando-se os objetivos organizacionais com os dos colaboradores. Dessa forma, benefícios são considerados como um diferencial estratégico e competitivo no mercado.

Segundo Gaulke e Nicoleti (2007, p. 02), “o salário pago em relação ao cargo ocupado constitui somente uma parcela do pacote de compensações que as organizações costumam oferecer a seus funcionários". Dessa forma, infere-se que os benefícios constituem uma parte considerável da remuneração total, proporcionando vantagens e conveniências com o intuito de impactar de forma positiva o bem estar dos colaboradores.

Tendo em vista que a oferta de benefícios impacta de forma direta na produtividade e comportamento dos colaboradores, bem como em sua percepção quanto ao cargo ocupado, deve-se levar em conta os diferentes perfis de forma a satisfazer as necessidades existentes. Portanto, é necessária a diferenciação dos benefícios para que os mesmos possam ser utilizados como ferramenta de motivação e não se tornem fonte de insatisfação (CLARO; PROFETA, 2018).

Para Wood Jr. e Picarelli Filho (2004), os benefícios respondem por parte considerável da remuneração total, influenciando no poder de decisão e aceitação de ofertas de emprego, representando um importante auxílio ao colaborador no âmbito econômico por oferecer segurança financeira adicional, 
bem como facilitar o acesso aos serviços básicos e atividades sociais de cunho recreativo e educacional.

Os benefícios podem ser divididos em compulsórios e espontâneos. Os benefícios sociais compulsórios são exigidos pela legislação trabalhista ou previdenciária com o intuito de cumprir acordos com sindicatos ou normas legais previamente estabelecidas. Quanto aos benefícios sociais espontâneos, são oferecidos mediante o objetivo de satisfazer as necessidades dos colaboradores, tornando atrativo e competitivo o perfil da remuneração no mercado de trabalho (MARRAS, 2009).

As técnicas de administração, principalmente as referentes aos sistemas de remuneração, foram modificadas e atualizadas para proporcionar a satisfação dos colaboradores, passando a fazer parte da Responsabilidade Social Corporativa das organizações, provocando um aumento na personalização das ações empresariais com foco nos distintos perfis existentes em no ambiente de trabalho.

\subsection{RESPONSABILIDADE SOCIAL CORPORATIVA}

A responsabilidade social da empresa pode ser concebida como auxílio na regulação jurídica ao obedecer às normas judicialmente cabíveis. Contudo, também pode ser utilizada como propagação do bem-estar social, onde, a princípio, inferia a percepção de filantropia, mas com o passar das décadas, tornou-se uma forma de dar ênfase na transformação dos recursos econômicos em benefícios sociais e nas vantagens ocasionadas pela gestão social.

De acordo com Moura et al (2004), as empresas passaram a assumir as responsabilidades sociais pelos problemas decorrentes da atividade empresarial própria, apesar de sua orientação essencial para o lucro, tomaram consciência de que são capazes de promover o bem-estar dos seus colaboradores através de programas de assistência, cuidados inerentes á segurança e higiene no trabalho.

A responsabilidade social corporativa para os colaboradores significa vantagens salariais, auxilio educacional de forma a aumentar as probabilidades de formação, acesso aos benefícios sociais, proporcionando incentivos que apresentam por objetivo tornar os colaboradores socialmente responsáveis (SEBASTIÃO, 2009).

O modelo de gestão orientado pela responsabilidade social corporativa tem por objetivo promover os direitos humanos, onde se envolvem aspectos como sustentabilidade e governança, tendo indicadores como o respeito às gerações futuras, participação dos gestores, liderança social, e por fim, o comprometimento ético que causa impactos positivos na qualidade de vida dos colaboradores e de seus familiares (ALBUQUERQUE, 2009). 
Dessa forma, cabe ressaltar que a responsabilidade social resume-se ao exercício da cidadania corporativa que, quando alinhada com o planejamento estratégico, torna-se uma forma de reforçar a imagem da empresa para os seus colaboradores. Tal responsabilidade está vinculada aos valores e à ética com os quais a empresa desenvolve suas atividades no mercado, lida com os agentes envolvidos na cadeia de negócios e corrobora para a sustentabilidade no contexto organizacional.

\subsection{MOTIVAÇÃO NO AMBIENTE DE TRABALHO}

A motivação humana resulta de estudos contínuos que apresentam por objetivo compreender como se pode criar cenários propícios para desenvolver atividades de forma saudável. Sendo assim, no atual cenário organizacional reconhece-se que as mensurações das necessidades e comportamentos individuais não podem ser padronizadas, buscando-se formas gradativas de fazer com que os colaboradores se sintam importantes, através da satisfação ocasionada pelo reconhecimento advindo do trabalho e, com isso, se sintam parte do grupo social.

Em períodos próximos ao atual, uma parte dos adeptos da administração científica de Taylor iniciaram a propagação da ideia de que os indivíduos não escolhiam os empregos por suas características, mas sim pela remuneração prometida. Dessa forma, encontra-se o primeiro fator motivacional dentro das empresas. Contudo, a motivação não garante o desempenho, onde deve-se fornecer o ambiente adequado para que exista o impulso interior por parte do colaborador para alcançar os objetivos. (GREGOLIN; PATZLAFF; PATZLAFF, 2011).

De acordo com Castro (2004, p. 86), “o processo motivacional individual busca a manutenção do equilíbrio, sendo que a energia usada para este, vem da capacidade de cada um em se auto motivar, a qual é desenvolvida ao longo do tempo". Tal afirmação implica na necessidade de as empresas de terem colaboradores comprometidos e motivados de forma a agregar valor para suas qualidades profissionais. De acordo com Claro e Profeta (2018, p. 119):

o aspecto motivacional é composto por fatores de abrangências diversas e que os mais perenes são aqueles que se originam no próprio indivíduo. Por outro lado, existem fatores motivacionais que podem ser estimulados por meio de ações objetivas da organização, na forma de disponibilização de benefícios tangíveis e imediatos, que causem diferenciação entre as organizações enquanto opções de local de trabalho, empregadoras e retentoras de talentos.

Dessa forma, o capital humano caracteriza-se como uma parte importante do sucesso das empresas, passando de um insumo para um recurso que deve ser administrado, possibilitando ações com foco no potencial humano e execução de processos que auxiliem na compreensão do comportamento dos 
colaboradores de forma a satisfazer suas necessidades por intermédio de orientações motivacionais intrínsecas e extrínsecas.

\subsection{METODOLOGIA MULTICRITÉRIO DE APOIO Á DECISÃO}

A concepção e solução de problemas de decisão possuem um grande impacto dentro do ambiente empresarial, pois em diversos contextos, é necessário que se faça a avaliação de um ambiente complexo, que sejam implementadas decisões utilizando- se de múltiplos critérios e aspectos derivados desse ambiente, definindo como legítimos os problemas e métodos da área a ser estudada. Nada mais natural que se baseie em uma metodologia multicritério de apoio à decisão a fim de se obter sucesso no processo decisório e otimizar variáveis.

Um processo de apoio à decisão caracteriza-se como um processo de interação com uma situação problemática, no qual tem-se por objetivo a construção de uma estrutura partilhada entre os decisores, sendo assim, atividades de apoio à decisão devem ser suportadas em modelos formalizados, com o intuito de se elaborar recomendações que respondam o mais claramente possível ás questões levantadas pelos decisores no decorrer de um processo de decisão (BANA; COSTA, 1995).

A metodologia multicritério não apresenta o objetivo de conceber apenas uma solução viável, mas sim, viabilizar a concepção de alternativas ideais que podem ser adotadas para a resolução de um problema. Para Silveira Jr. (2018, p. 60) a metodologia multicritério de apoio á decisão define-se como:

uma metodologia voltada para analisar situações complexas - a partir de um conjunto de indicadores quantitativos e qualitativos distintos, incluindo indicadores financeiros, físicos, de insumos, de processos, de produtos e de resultados -, que pode ser utilizada tanto para apoio à decisão quanto como um conjunto de técnicas analíticas.

Segundo Ensslin et al (2001, p. 145), a metodologia multicritério é realizada por meio de três fases básicas: "i. a estruturação do contexto decisório; ii. a construção de um modelo de avaliação de alternativas/ações; e iii. a formulação de recomendações para os cursos de ações mais satisfatórias". A utilização dessa metodologia fornece, ao seu final, informações para subsidiar a tomada de decisão dos responsáveis que a devem fazer de forma estruturada e clara, a fim de se escolher as alternativas que melhor contribuem para a empresa como um todo.

Em síntese, no que se refere a aplicabilidade o método multicritério de apoio a decisão pode ser utilizada com eficácia tanto no apoio ao processo decisório, quanto na realização da análise e avaliação de decisões previamente tomadas e que envolvam situações complexas, por vezes, conflitantes. Determinando-se se os objetivos de uma decisão foram ou não atingidos (SILVEIRA JR., 2018). 
Diante do exposto, a metodologia multicritério é ideal para modelos que consideram mais de um aspecto e avaliam ações de acordo com um conjunto determinado de critérios, onde pode-se contemplar a resolução de problemas e propostas para implementar soluções, sendo ainda utilizado quando o tomador de decisão utiliza seu conhecimento e poder de julgamento com o intuito de desenvolver e implementar melhorias na avaliação geral.

\section{METODOLOGIA DE PESQUISA}

O instrumento de pesquisa consistiu em um modelo multicritério de avaliação, que no caso deste estudo, seguiu as premissas propostas por Ensslin et al (2001). Inicialmente, definiu-se o rótulo do modelo como: "Plano de benefícios sociais como ferramenta de motivação dos colaboradores de uma empresa automotiva: uma avaliação multicritério". Em sequência, identificou-se os atores envolvidos nos processos de avaliação, a saber: agidos, decisores e facilitadores.

Como resultado das reflexões iniciais sobre o rótulo, ocorreu uma estruturação hierárquica baseada nos planos de benefícios oferecidos pela empresa. Em seguida, realizou-se a identificação dos elementos de avaliação, denominados como critérios ou Pontos de Vistas Fundamentais (PVFs), os quais foram validados pelos decisores, constituindo-se, assim na família de PVFs do modelo. Estes, devido a complexidade dos mesmos, foram decompostos em Pontos de Vistas Elementares (PVEs), quando necessário, constituindo-se, assim, a estrutura básica do modelo multicritério de decisão, conforme apresentada a seguir:

\section{a) PVF 1 - Plano de benefícios assistenciais}

- PVE 1.1 - Seguro de vida em grupo

- PVE 1.2 - Plano de assistência médico-hospitalar e odontológica

- PVE 1.3 - Reembolso de medicamentos

- PVE 1.4 - Assistência financeira

b) PVF 2 - Plano de benefícios educacionais

c) PFV 3 - Plano de benefícios supletivos

- PVE 3.1 - Fornecimento de vale refeição

- PVE 3.2 - Fornecimento de cesta básica

- PVE 3.3 - Estacionamento privativo

- PVE 3.4 - Participação nos lucros e resultados

- PVE 3.5 - Vale transporte ou vale combustível 
No passo seguinte, definiu-se os descritores dos critérios de avaliação, que corresponde ao conjunto de níveis de impacto destinado a medir a performances das ações potenciais. Os descritores utilizados foram comuns para todos os critérios de avaliação. Vide detalhamento no Quadro 1.

Quadro 1 - Descritores dos critérios de avaliação

\begin{tabular}{|c|c|}
\hline Nivel de Impacto & Descritor \\
\hline N5 & Muito satisfeito \\
\hline N4 & Satisfeito \\
\hline N3 & Indiferente \\
\hline N2 & Insatisfeito \\
\hline N1 & Muito insatisfeito \\
\hline
\end{tabular}

Fonte: Autores

Posteriormente, quantificou-se a performance das ações potenciais que resultaram nas funções de valor, atividade realizada com o apoio do método Measuring Attractiveness by a Categorical Based Evaluation Technique (Macbeth), que utiliza a programação linear para determinar as funções de valor que melhor representem os julgamentos semânticos dos decisores. Dessa forma, a partir dos parâmetros definidos pelos decisores, foram construídas matrizes de julgamento semântico, uma para cada PVE. A título de exemplo, apresenta-se na Figura 1, a matriz de julgamento semântico do PVE 1.1 - Seguro de vida em grupo.

Figura 1 - Matriz semântica do PVE 1.1 - Seguro de Vida em Grupo

\begin{tabular}{|c|c|c|c|c|c|c|c|}
\hline \multicolumn{6}{|c|}{ ofs Macbeth : PVE 1.1 - SVG } & - & $\square$ \\
\hline & N5 & N4 & N3 & N2 & N1 & $\begin{array}{l}\text { Current } \\
\text { scale }\end{array}$ & extreme \\
\hline N5 & no & weak-mod & moderate & v. strong & strg-vstr & 100 & V. strong \\
\hline N4 & & no & mod-strg & strong & strong & 73 & strong \\
\hline N3 & & & no & mod-strg & mod-strg & 53 & moderate \\
\hline N2 & & & & no & moderate & 20 & woak \\
\hline N1 & & & & & no & 0 & very weak \\
\hline \multirow{2}{*}{\multicolumn{8}{|c|}{ Consistent judgements }} \\
\hline & & & & & & & \\
\hline 핑 & & 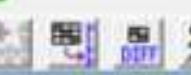 & Fis & & & & \\
\hline
\end{tabular}

Fonte: Macbeth 
Na sequência, ao finalizar o modelo, determinou-se, em conjunto com os decisores, as taxas de substituição (pesos) dos critérios e subcritérios, conforme demonstrado na Figura 2, que apresenta a estrutura arborescente do modelo desenvolvido.

Figura 2 - Árvore de Valor

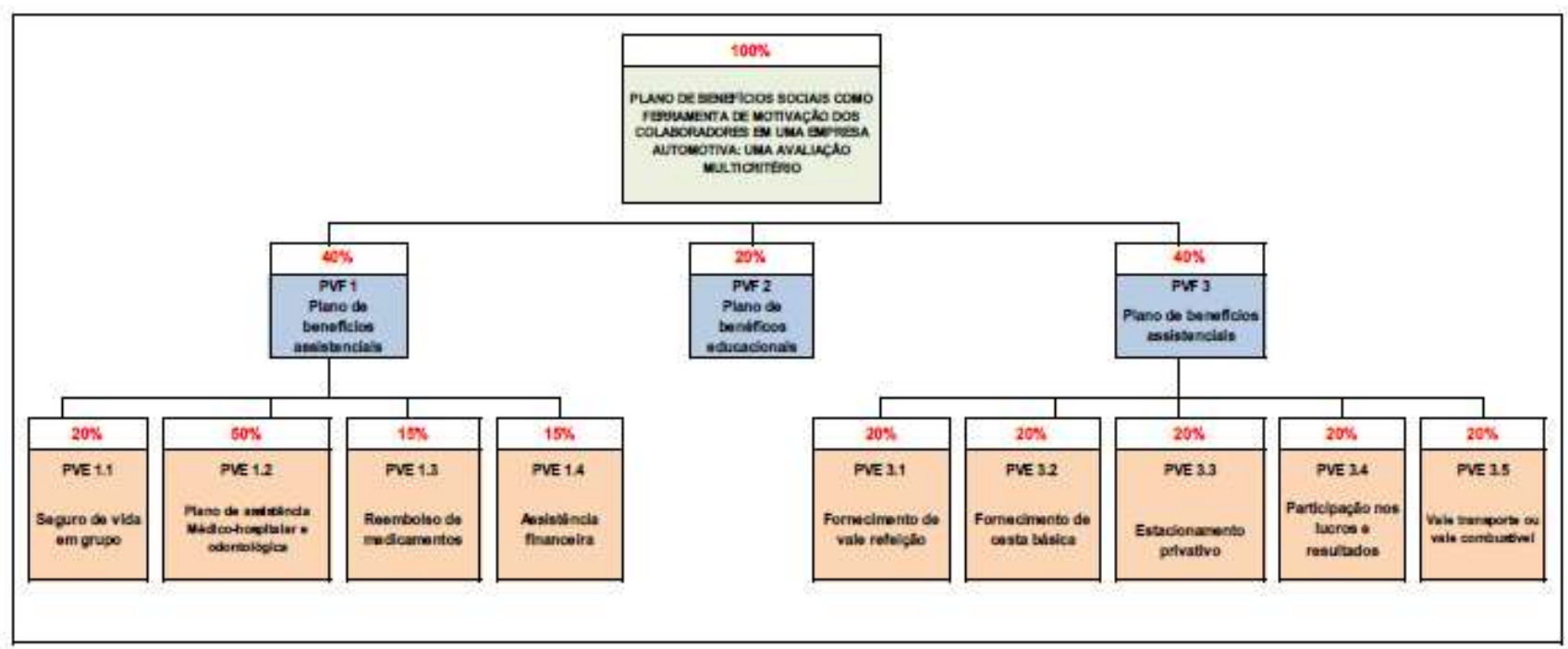

Fonte: Autores

Diante dos objetivos propostos, a pesquisa realizada classifica-se, que tange aos fins, como aplicada, descritiva e exploratória; quanto aos meios, caracteriza-se como pesquisa bibliográfica, pesquisa de campo e estudo de caso. Na visão metodológica, no tocante á abordagem da pesquisa, a mesma utilizou-se de métodos qualitativos e quantitativos.

Após a conclusão do modelo, elaborou-se o questionário a ser utilizado na pesquisa de campo, valendo-se, para tanto, dos subcritérios e do critério 2 para dar origem as perguntas, cujo os descritores constituíram-se nas alternativas de respostas.

\section{APRESENTAÇÃO E ANÁLISE DOS RESULTADOS}

Realizou-se a pesquisa de campo no período de 23 a 26 de outubro de 2018, de forma presencial com todos os 42 colaboradores lotados no escritório da empresa analisada, mediante a aplicação do questionário. Os resultados foram tratados pelo aplicativo Hievew3, a partir das premissas e parâmetros definidos pelos decisores, constantes do modelo de avaliação. Apresenta-se na Quadro 2 o resumo do resultado das avaliações dos PVFs e global. 
Quadro 2 - Resultados das avaliações

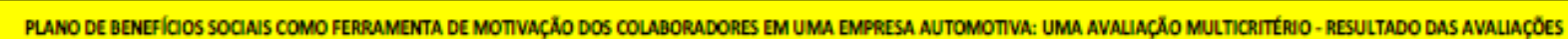

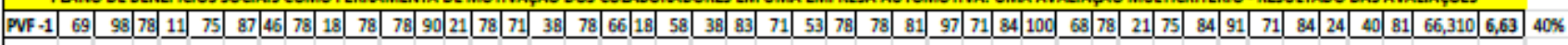

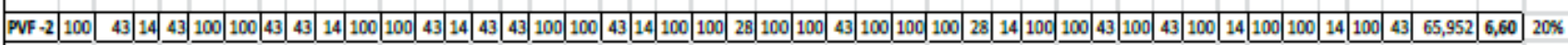

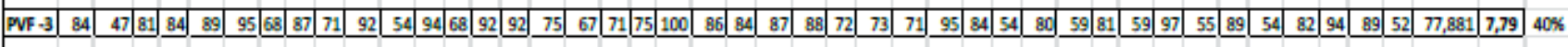

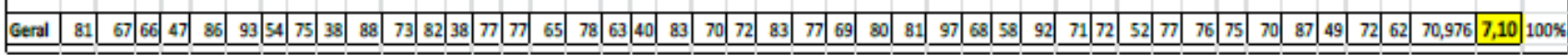

\section{Fonte: Autores}

As respostas dos colaboradores, após serem tabuladas e tratadas pelo software Hiview3, constituíramse nos insumos para propiciar o cálculo das avaliações quantitativas de cada PVF e, a partir das notas atribuídas a estes, calculou-se a nota referente á avaliação global.

Para o cálculo da avaliação quantitativa dos critérios (PVFs), avaliações parciais, definiu-se a seguinte fórmula de agregação aditiva (adaptada de Ensslin et al., 2001):$$
\mathbf{A}(\mathrm{PVF})=\sum_{j=1}^{n}\left[\sum_{i=1}^{m} p i .(F V i E j)\right]
$$

Onde:

- $\mathbf{A}(P V F)=$ avaliação do PVF;

- $p \boldsymbol{i}=$ taxa de substituição (peso) do PVE $\boldsymbol{i}$;

- $($ FViE $j)=$ função de valor do Entrevistado $\boldsymbol{j}$ impactada no PVE $\boldsymbol{i}$;

- $\boldsymbol{m}=42$ (número de entrevistados);

- $\boldsymbol{n}$ = número de subcritérios (PVE).

Tal equação está submetida às seguintes restrições:

- o somatório das taxas de substituição deve ser igual a $100(p 1+p 2+\ldots+p n=100 \%)$;

- o valor das taxas de substituição deve ser maior do que zero e menor do que $100(0<$ pi $<100$, para $i=1,2, \ldots n) ;$

Para o cálculo da avaliação global (nota final), definiu-se a fórmula de agregação aditiva indicada a seguir, adaptada de Ensslin et al., (2001):

$$
\mathrm{AG}=\sum_{i=1}^{n} x i \cdot y i P V F
$$

Onde: 
- AG = avaliação global;

- yi (PVF) = pontuação parcial do PVF $\boldsymbol{j}$

- $x \boldsymbol{i}$ = taxa de substituição dos critérios 1, 2 e 3 (PVFs);

- $\boldsymbol{n}=3$ (número de PVFs);

Tal equação está submetida às seguintes restrições:

- o somatório das taxas de substituição dos PVFs deve ser igual a 100 (y1 + y2 + y3 = 100\%);

- o valor das taxas de substituição deve ser maior do que zero e menor do que $100(0<$ yi < 100, para $\boldsymbol{i}=1,2$ e 3 ).

A avaliação global do plano de benefícios, sob a ótica dos colaboradores, atingiu a nota final de 7,10 numa escala de 0 a 10. Pode-se considerar como uma nota satisfatória, mas que poderia ser maior, em virtude dos investimentos e inovações realizados pela empresa no que se refere a remuneração indireta. As justificativas para essa avaliação são apresentadas nas análises a seguir.

No PVF 1 - Plano de benefícios assistenciais, que possui peso de 40\%, analisou-se quatro Pontos de Vistas Elementares: Seguro de vida em grupo, Plano de assistência médico-hospitalar e odontológica, Reembolso de medicamentos e Assistência financeira. A avaliação final desse PVF atingiu a pontuação de 6,63. A Figura 3 apresenta as pontuações ponderadas dos Entrevistado em relação a cada PVE.

Figura 3 - Pontuações ponderadas do PVF 1 - Plano de benefícios assistenciais

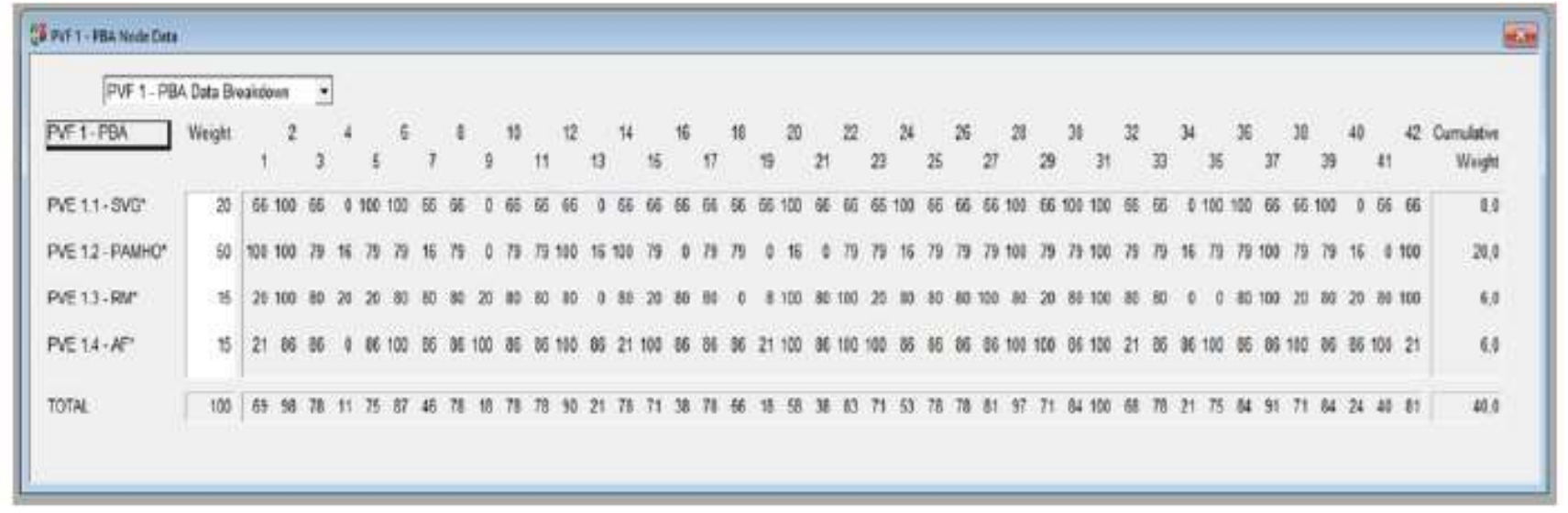

Fonte: Hievew3

Dentre os possíveis motivos para essa nota não ter recebido 10, destacam-se a necessidade de atualização dos benefícios de acordo com as faixas etárias, bem como, os colaboradores levantaram aspectos negativos com relação à operadora responsável pelo plano de assistência médica, alegando 
que estão ocorrendo falhas quanto às marcações de consultas e principalmente de exames. Insta salientar as inconsistências quanto às porcentagens dos valores de medicamentos reembolsados, resultantes das diferenças de percentuais de reembolso entre os níveis hierárquicos.

Quanto ao PVF 2 - Plano de benefícios educacionais, com peso de $20 \%$, não está desmembrado em PVEs e sua pontuação final foi 6,60, a menor entre os critérios, o que não demonstra uma insatisfação generalizada por parte dos colaboradores, mas reflete o descontentamento por uma parcela deles com esse plano específico de benefícios.

Tal avaliação, de acordo com as entrevistas realizadas, é proveniente da falta de mapeamento das reais necessidades dos colaboradores. As avaliações negativas que impactaram a pontuação final do PVF foram provenientes do fato de que alguns colaboradores haviam realizado anteriormente o curso oferecido ou não tinham interesse em realizá-lo, e dessa forma, desejam a oferta de novas opções. Bem como, apresentaram dúvidas quanto á concessão do benefício no que se refere à participação da empresa nos custos monetários desse benefício, o que demonstra um ruído na comunicação interna.

No que se refere ao PVF 3 - Plano de benefícios supletivos, com peso de $40 \%$, considerou-se para fins de avaliação, cinco Pontos de Vistas Elementares: Fornecimento de vale refeição, Fornecimento de cesta básica, Estacionamento privativo, Participação nos lucros e resultados e Vale transporte ou vale combustível. Este foi o critério melhor avaliado, recebeu a pontuação 7,79, para uma escala de 0 a

10. Apresenta-se na Figura 4 as pontuações ponderados dos Entrevistados em todos os PVEs deste critério.

Figura 4 - Pontuações ponderadas do PVF 3 - Plano de benefícios supletivos

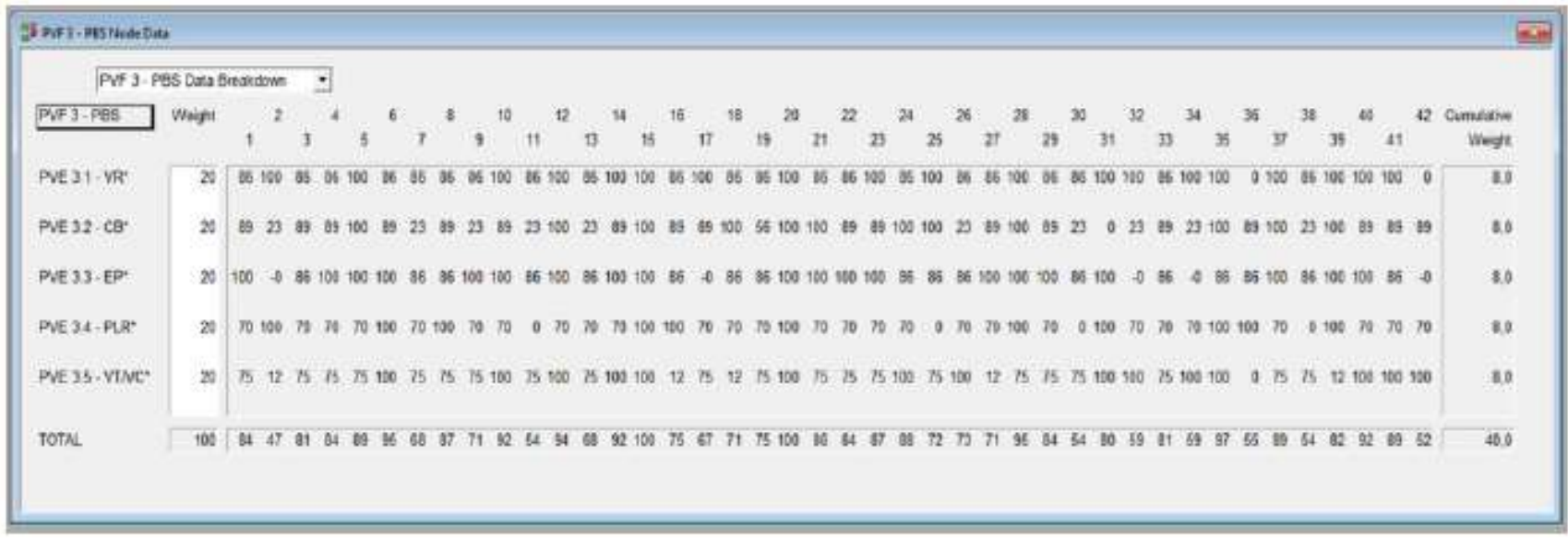

Fonte: Hievew3 
A pontuação final obtida pelo PVF 3 reflete o esforços desenvolvidos pela empresa para melhorar a qualidade de vida dos colaboradores. Pode-se expor uma série de variáveis que induziram os entrevistados a impactarem essa avaliação, dentre elas está a recente reestruturação do plano de benefícios supletivos, que após uma pesquisa de satisfação, a empresa formalizou novos contratos com fornecedores que ofertam uma melhor qualidade nos serviços e produtos, propiciando atualização dos valores dos benefícios e, com isso, se adequaram aos avanços econômicos e às preferências mercadológicas específicas dos colaboradores.

Contudo, existem alternativas de melhorias que devem ser implementadas, pois os colaboradores alegaram que ainda existem atualizações a serem realizadas de forma a personalizar os benefícios de acordo com os seus perfis socioeconômicos. Como exemplo, cabe inferir o não atendimento das demandas de alguns colaborados que residem longe do escritório e que dispendem uma quantidade maior de recursos financeiros para se locomoverem.

Outro fator de insatisfação identificado nas entrevistas consiste na alteração da cartela de produtos que compõem a cesta básica, o que ocasionou um aumento considerável no valor da taxa cobrada por esse benefício na folha de pagamento. Nos demais PVEs, foram levantadas algumas avaliações negativas que resultam de necessidades pessoais e financeiras de alguns colaboradores, as quais devem ser compreendidas pela empresa para não ocasionar desmotivação de colaboradores.

Nota-se, por fim, que as notas auferidas em todos os critérios foram superiores ao mínimo aceitável, que seria 5,0. Embora as notas demonstrem que existem melhorias que devem ser implementadas para alcançar a satisfação de uma maior quantidade de colaboradores, nenhum critério foi criticamente avaliado ou demonstrou uma insatisfação generalizada, mas a empresa deve ter atenção quanto a personalização dos benefícios de acordo com a faixa etária e com as necessidades reais dos colaboradores.

Por fim, apresenta-se, para fins de demonstração, o Gráfico da Figura 5 com a participação de cada PVE na avaliação global, de acordo com os pesos dos mesmos e com as pontuações impactadas em função das respostas dos participantes da pesquisa.

Figura 5 - Participação de cada PVE no resultado global 


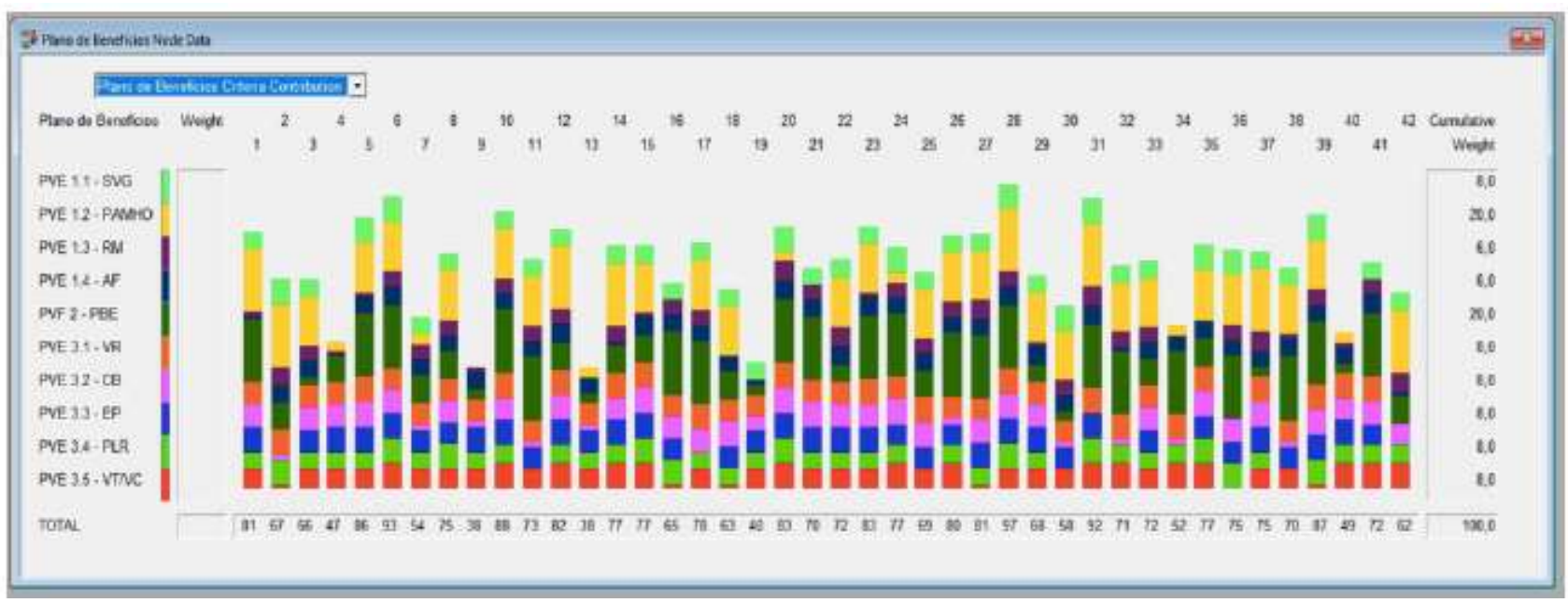

Fonte: Hievew3

Em seguida, comentar-se-á sobre a análise de sensibilidade aplicada ao modelo.

\section{ANÁLISE DE SENSIBILIDADE}

O modelo de avaliação, apesar de ter sido concebido com esmero e dedicação por parte dos decisores, testou-se a robustez do modelo por meio de análise de sensibilidade.

Após a realização do tratamento dos dados levantados na pesquisa de campo e do cálculo das avaliações dos critérios e global, precedeu-se a análise de sensibilidade do modelo multicritério de avaliação a partir de uma variação de $10 \%$ para mais e para menos nos pesos de cada um dos PVFs e recalculou-se as avaliações. Para ajustar os pesos dos demais quando se modificou o peso de um determinado critério, utilizou-se a fórmula proposta por Ensslin et al (2001), indicada a seguir:

$$
p n^{\prime}=\frac{p n \cdot\left(1-p i^{\prime}\right)}{(1-p i)}
$$

Onde:

- $\quad \mathrm{pi}=$ taxa de substituição (peso) original do critério i;

- $\quad$ pi '= taxa de substituição (peso) modificada do critério i;

- $\quad \mathrm{pn}=$ taxa de substituição (peso) original do critério $\mathrm{n}$;

- $\quad p n^{\prime}=$ taxa de substituição (peso) modificada do critério $n$.

Apresenta-se na Figura 6 um gráfico com a posição das ações potenciais na linha de corte da taxa de substituição original de 40\% do PVF 1 - Plano de benefícios assistenciais. 
Figura 6 - Posição das ações na linha de corte de 40\% do PVF1

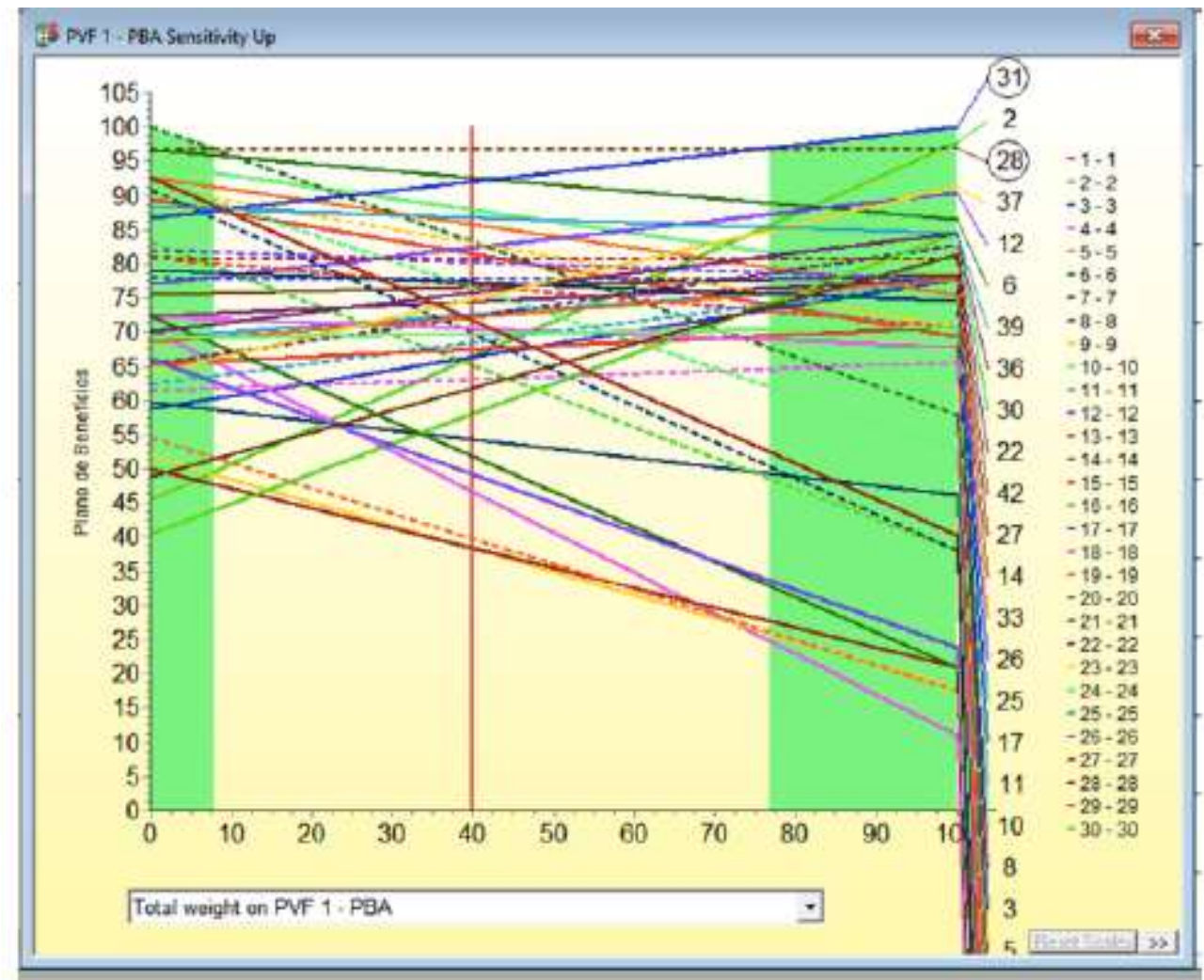

Fonte: Hiview3

No gráfico da Figura 7, evidencia-se que uma variação de mais $10 \%$ na taxa de substituição do PVF 1 não acarretou alterações na posição das ações potenciais na linha de corte correspondente a 44\%.

Figura 7 - Posição das ações na linha de corte de 44\% do PVF1

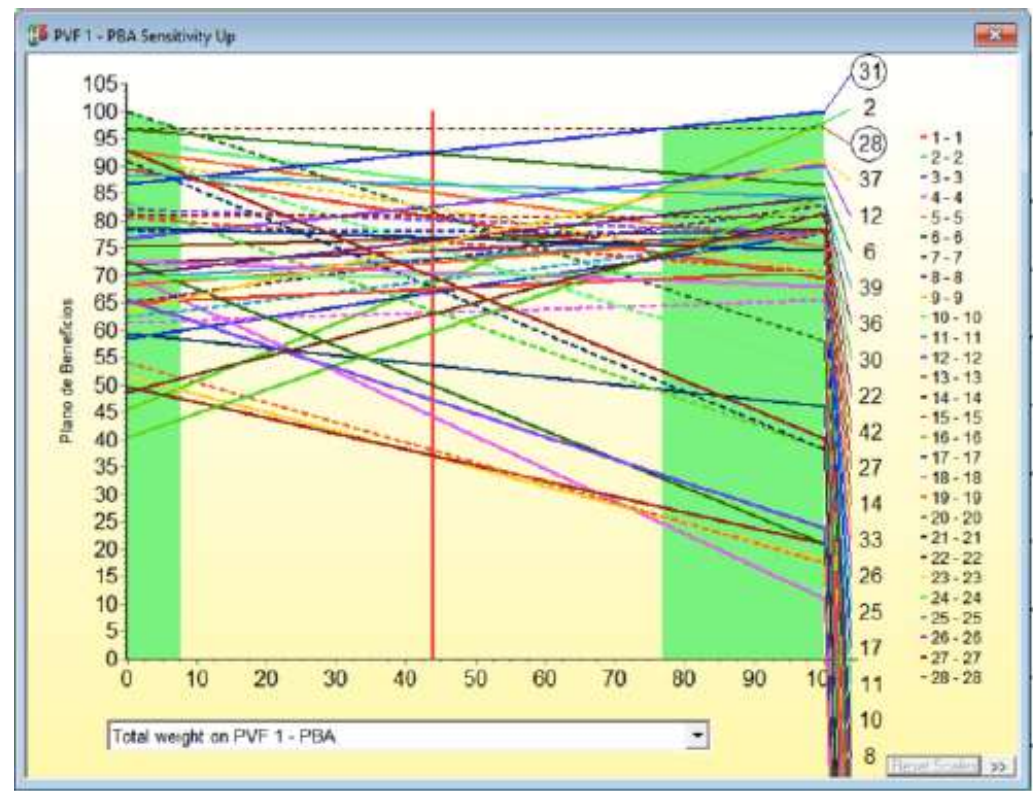

Fonte: Hiview3 
Por outro lado, o Gráfico da Figura 8, demonstra que também não houve modificação na posição das ações potenciais na linha de corte de $36 \%$, relativa á variação de $10 \%$ para menos na taxa de substituição do PVF 1.

Figura 8 - Posição na linha de corte de 36\% do PVF1

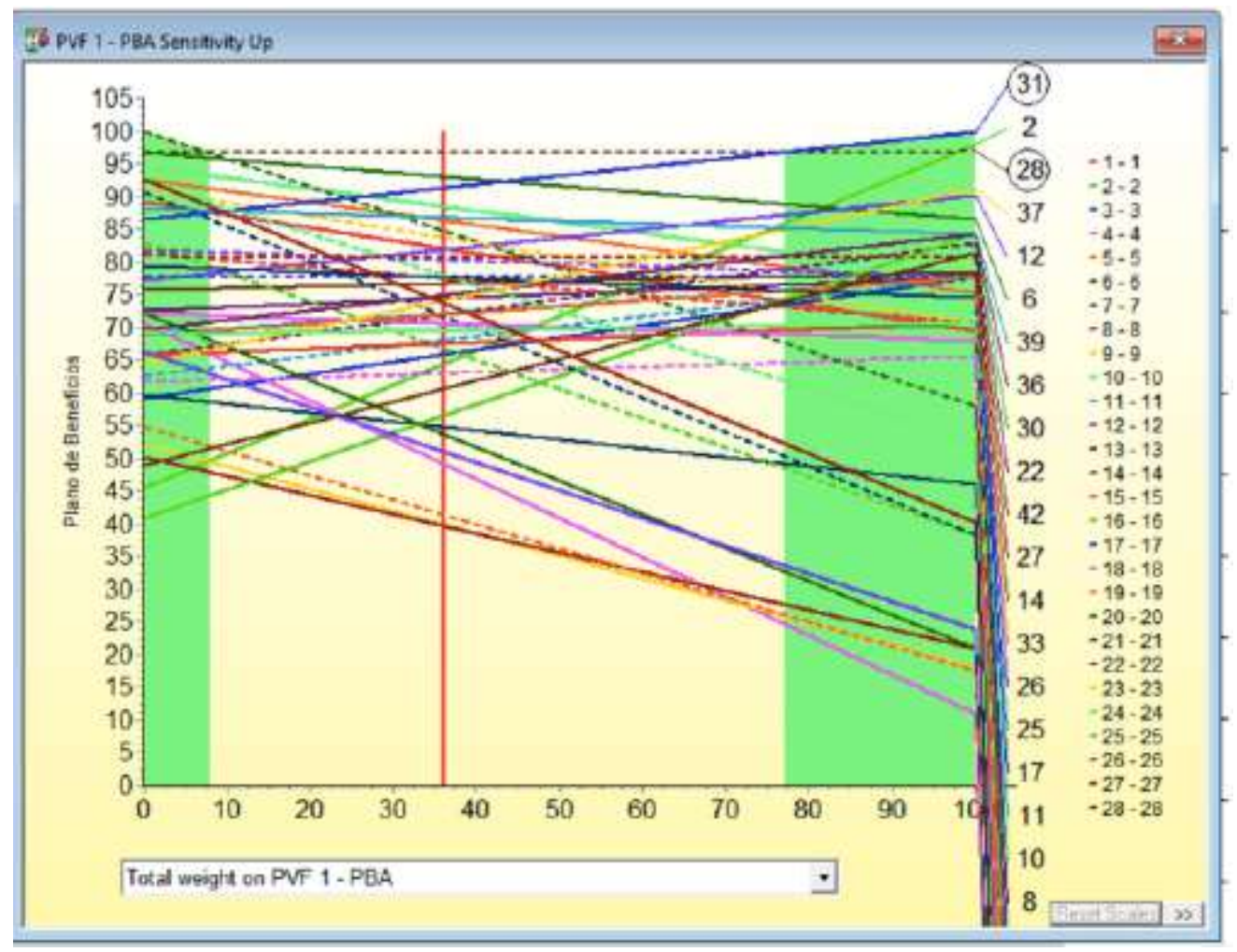

Fonte: Hiview3

O teste realizado com o PVF1, com a modificação de $10 \%$ para mais e para menos na taxa de substituição, foi replicado nos outros dois PVFs e, em nenhum caso, houve modificação na posição das ações em relação às linhas de corte, o que evidencia que o modelo é robusto e, por conseguinte, as avaliações calculadas são fidedignas.

\section{CONCLUSÃO}

O estudo realizado teve por objetivo avaliar o grau de satisfação dos colabores de uma empresa automotiva com o plano de benefícios da empresa. Para tanto foi desenvolvido um modelo multicritério de avaliação, o qual se mostrou aderente aos propósitos do que se pretendia pesquisar. A avaliação global do plano de benefícios sociais da empresa estudada atingiu a nota 7,10, o que reflete uma satisfação boa por parte dos colaboradores com o plano. Para a empresa, foi uma resposta 
satisfatória às estratégias de remuneração indireta que que estão sendo implementadas, com finalidade última de motivar os colaboradores e alinhá-los aos objetivos organizacionais.

De forma geral, os colaboradores estão satisfeitos com o plano de benefícios sociais. Analisando-se de forma macro, os resultados das avaliações foram medianos quando considerado o alto investimento realizado em benefícios sociais, mas satisfatórios para a realidade da empresa que até cinco anos atrás quase não despendia tempo e recursos com remuneração indireta dos colaboradores. No entanto cabe uma análise individual de cada critério com o intuito de identificar alternativas de melhorias para preenchimento de possíveis lacunas.

O PVF1 - Plano de benefícios assistenciais recebeu a nota de 6,63, que apesar de não demonstrar uma insatisfação generalizada, evidencia que alguns benefícios, como o plano médico-hospitalar e odontológico, não estão atendendo aos diferentes perfis de colaboradores. Constatou-se tanto colaboradores com altos índices de satisfação, quanto insatisfações por não terem suas necessidades atendidas.

Para solucionar tal situação, recomenda-se que a empresa busque novas opções de fornecedores ou planos personalizados por faixa etária e que atendam às necessidades de todos os colaboradores.

O PVF 2 - Plano de benefícios educacionais foi avaliado com a nota de 6,60, que reflete as consequências da implantação de benefícios sem um estudo prévio sobre as reais necessidades dos colaboradores. Dessa forma, a empresa despende recursos financeiros com estratégias que não alcançam os níveis esperados de satisfação por parte dos colaboradores e os fizeram levantar questionamentos que impactam negativamente no clima organizacional.

Recomenda-se que sejam realizados estudos para identificar as reais necessidades dos colaboradores, no que concerne aos benefícios educacionais, a fim de que sejam efetuadas parcerias com instituições educacionais de nível superior, pois alguns colaboradores possuem formação somente até o ensino médio, e a maioria dos que possuem ensino superior demonstraram querer realizar cursos de pósgraduação.

O compromisso da empresa com a satisfação dos colaboradores refletiu-se na nota auferida ao PVF 3 - Plano de benefícios supletivos, o qual embora necessite alterações e adequações que devem ser executadas com brevidade, apresentou a melhor avaliação dentre os três PVFs, alcançando a pontuação 7,79. Esta nota evidencia que esse benefício contribui para o crescimento e fortalecimento empresarial, haja vista que o bem-estar dos colaboradores está vinculado ao sucesso da empresa. 
Contudo, recomenda-se ajustes nos valores do vale transporte e do vale combustível, fins satisfazendo adequadamente às demandas dos colaboradores que moram em locais mais distantes da empresa, de modo a evitar possíveis absenteísmos, descumprimentos dos horários da jornada de trabalho e até mesmo rotatividade. $\mathrm{O}$ incremento de melhoria neste benefício demonstrará o empenho da empresa em satisfazer as reais necessidades dos seus colaboradores.

Diante do exposto, conclui-se que os objetivos da pesquisa foram atingidos, pois foi construído um modelo multicritério de avaliação do plano de benefícios sociais, com apoio de uma equipe de decisores da própria empresa pesquisada, além de ter sido devidamente implementado e se ter conseguido mensurar o grau de satisfação dos colaboradores em relação aos benefícios oferecidos pela empresa. 


\section{REFERENCIAS}

ALBUQUERQUE, J. L. Gestão ambiental e responsabilidade social: conceitos, ferramentas e aplicações. 6. ed. São Paulo: Atlas, 2009.

BANA e COSTA, C.A. Processo de apoio à decisão: problemáticas, actores e acções. Apostila do Curso Metodologias Multicritério de Apoio à Decisão. ENE/UFSC. Florianópolis, 1995

CASTRO, A. P. Manual de gestão de pessoas e equipes: Estratégias e tendências. São Paulo: Editora Gente, 2004.

CLARO, J. A. C. S.; PROFETA, Rogério Augusto. Programas de benefícios sociais para profissionais brasileiros como forma de reter talentos: um estudo exploratório. Brazilian Journal of Management / Revista de Administração da UFSM, v. 11 (1), p. 117-153, 2018

ENSSLIN, L.; MONTIBELLER, G; NORONHA, S. Apoio à Decisão - metodologia para estruturação de problemas e avaliação multicritério para alternativas. Florianópolis:Insular, 2001.

GAULKE, C. N.; NICOLETI, G. G. Benefícios: usado como fator motivacional pela empresa Karsten S/A no setor tecelagem II 10 turno. Revista Interdisciplinar Científica Aplicada, Blumenau, v. 1, n. 2, p. 115, 1으 sem. 2007

GRegolin, M. R. P.; PATZlafF, A. C.; PATZlafF, P. M. G. Motivação para o trabalho e o comportamento humano nas organizações. Emancipação, Ponta Grossa,v.11,n. 1,p.5971,2011.Disponívelem:<http://www.revistas2.uepg.br/index.php/emancipacao/article/viewArticle/7 57>. Acesso em: 30 out. 2018.

MARRAS, J. P. Administração de Recursos Humanos: do Operacional ao Estratégico. São Paulo: Saraiva, 2009

MOURA, R., COELHO, V., MOURA, K., RAPOSO, R., BRITES, R., CARDIM, J.

(2004). Responsabilidade social das empresas: emprego e formação profissional. S. I.: MundiServiços LDA

SEBASTIÃO, S. P. (2009). Comunicação estratégica. As relações públicas. Lisboa: Guide- Artes Gráficas.

SILVEIRA JR., Aldery. Cabotagem brasileira: uma abordagem multicritério. Curitiba: Appris, 2018.

WOOD JR., T.; PICARELLI FILHO, V. Remuneração estratégica: a nova vantagem competitiva. 3. ed. São Paulo: Atlas, 2004 


\section{Capítulo 4}

\section{d.)}

\section{INOVAÇÃO NO CONTEXTO TÊXTIL E DO VESTUÁRIO: O QUE A LITERATURA APRESENTA SOBRE O TEMA?}

Marcio José Silva

Poliana da Silva Santos
Universidade Estadual de Maringá

Universidade Estadual de Maringá 
Resumo: O objetivo desta pesquisa foi o de investigar sobre os diferentes aspectos de inovação encontrados no contexto têxtil e vestuário. Isso foi feito por meio de uma análise sistemática de literatura. $O$ estudo priorizou as publicações que tratam diretamente sobre a inovação nesse contexto. Considerando que a inovação pode ser relacionada à tecnologia, melhoria de processos ou atividades em benefício dos usuários, isso foi levado em consideração para a análise. Após a seleção dos materiais encontrados, realizou-se a apresentação de tais publicações, seus objetivos e gaps teóricos para futuras pesquisas nesse contexto. Descobriu-se que há pesquisas em dois grandes grupos, um ligado a apenas investigação da inovação e outro com a aplicação da inovação em si. Conclui-se que a inovação nesse contexto é algo relativamente novo no Brasil, que caminha para a proposta de soluções em questões de processos de produção e melhoria de produtos e há possibilidades de se explorar a inovação até mesmo pelo sentido de produtos e processos mais sustentáveis.

Palavras-chave: Inovação; Indústria Têxtil; Indústria do Vestuário. 


\section{INTRODUÇÃO}

O setor têxtil e de vestuário possui grande importância pelo ponto de vista econômico do Brasil, isso se dá principalmente por sua grande contribuição na geração de emprego e renda. De acordo com dados consolidados pela Associação Brasileira das Indústrias Têxteis e de Confecção (ABIT, 2019), o setor é o segundo maior empregador da indústria de transformação. A cadeia produtiva têxtil/vestuário é composta por processos que vão desde a produção da fibra até a confecção do produto.

A indústria têxtil é a responsável pela criação dos têxteis que serão empregados na confecção de diferentes produtos, como os de vestuário. Já a do vestuário pela confecção dos tecidos nesses produtos e, é caracterizada por fatores como ênfase em processos criativos, amplo mix de produtos, grande necessidade e disposição de matérias-primas, curto ciclo produtivo e de produtos e pela interferência das tendências de moda (FINARDI; SILVA; RADOS, 2016; SILVA et al., 2018).

Nesse contexto, esse setor necessita de estratégias que visem alinhar tanto sua estrutura produtiva quanto novas técnicas, no sentido de desenvolvimento de produto. Inserido em um contexto altamente competitivo a inovação, de produtos e processos, passa a ser a chave para a sustentabilidade dessas empresas no mercado. De acordo com Balestrin e Verschoore (2010), a inovação abrange determinados fatores como recursos tecnológicos, realização de atividades por meio de projetos, verificação das necessidades do mercado, integração das equipes de trabalho e cooperação entre diversos envolvidos.

Percebe-se que a atenção dada a inovação, no que se refere a produtos, é vista com maior ênfase na literatura, no entanto de acordo com Ashok, Narula e Martinez-Noya (2016) a inovação também se associa a processos, criação de um novo método de produção, melhoria de determinada atividade, ou ações que visem a melhora significativa e transmita valor para os usuários. Para Oliveira e Epaminondas (2014), a inovação e o conhecimento são fatores que contribuem para o sucesso das empresas que atuam no setor têxtil e de vestuário.

O setor têxtil/vestuário é acrescido ainda da necessidade de melhoria no que se refere a seus modos de produção, garantindo produções mais enxutas e que criem impactos menos diretos ao ecossistema. Uma coleção de vestuário é desenvolvida em torno de 20 a 40 semanas, dependendo do tipo de comercialização, isso gera a necessidade de rápida tomada de decisões, grande quantidade de resíduos, diferentes envolvidos nos processos e a necessidade de alinhar os produtos desenvolvidos 
às tendências de moda atuais (SEN, 2008; KACHBA; HATAKEYAMA, 2015; SILVA, 2017; SILVA et. al., 2018). Diante do contexto apresentado este trabalho busca responder ao seguinte problema de pesquisa: Quais aspectos de inovação são encontrados no contexto têxtil e de vestuário, na área acadêmica e no ambiente organizacional?

\section{INOVAÇÃO COMO ESTRATÉGIA DE DESENVOLVIMENTO DE PRODUTOS}

A inovação é essencial para as estratégias de desenvolvimento das empresas, sendo o diferencial para sua sobrevivência e, em si é considerada a transformação de algo em algo novo (FEITOSA et al., 2014). Para que a inovação se concretize são necessários estudos e pesquisas para averiguar as necessidades da empresa, para então a formação de um novo produto ou serviço. Para que isso ocorra é necessário uma vasta concentração de informações, pesquisas de mercado, observações do ambiente e a percepção de que a inovação vai além de fatores internos à empresa, pois envolve tecnologias e novos materiais, criando novas possibilidades por meio da junção dos conhecimentos (FEITOSA et al., 2014; BRITTO; KITAZAWA, PEPECE, 2019).

Um processo que leva a inovação consiste em implementar um produto ou serviço novo ou melhorado, isso pode ser feito na empresa como um todo ou em áreas específicas (FREIRE, 2015; BALESTRIN; VERSCHOORE, 2010). Trata-se de um processo de várias etapas transformando ideias em produtos, serviços ou processos com a finalidade de se diferenciar no mercado (BUCHELE et al., 2017). No entanto para que esse processo se torne possível é necessário a realização de algumas etapas, dentre elas: diagnóstico do problema; realização da pesquisa; desenvolvimento dos produtos e comercialização; não sendo necessárias estar nesta sequência, mas sim todas serem realizadas (FEITOSA et al., 2014; BRITTO; KITAZAWA, PEPECE, 2019).

Para Oliveira e Epaminondas (2014) a inovação ocorre nas empresas por meio dos colaboradores que possuem capacidades e habilidades para criar algo que será comercializado. Isso é feito por meio de ideias inovadoras, consideradas como atividade individual, enquanto a inovação uma ação coletiva. As empresas identificam as aberturas no mercado por meio de seus conhecimentos, tecnológico e de mercado com o objetivo de gerar novos produtos com grande resultado (REICHERT; CAMBOIM; ZAWISLAK, 2015).

O Fórum de Inovação, consórcio de organizações da Escola de Administração de Empresas de São Paulo da Fundação Getúlio Vargas (FGV- EAESP), difere a inovação em quatro vertentes, sendo elas: inovação de produtos e serviços; inovação de processos; inovação de negócios e; inovação em gestão 
(TORRES; SILVA, 2014). Existe também as inovações ecológicas ou as eco inovações que podem ser diferenciadas em três processos, dentre eles, eco-processos, co-produtos e eco-design, sendo classificados como tecnologias sustentáveis, métodos de produção diferenciados, novas técnicas de produção, com potencial de gerar uma produção mais limpa e um consumo mais sustentável (BRASIL et al., 2016).

Diante disso é possível entender que inovação é um processo criativo, no qual se transforma algo já existente em algo novo, através de processos manuais e tecnológicos. Para que ela seja executada é necessário alguns estudos e pesquisas, transformando ideias em serviços e produtos. Ressaltando que a inovação é primordial para o crescimento das empresas que objetivam o aumento de lucro e venda de produtos.

\subsection{IMPORTÂNCIA DA INOVAÇÃO E SEUS ASPECTOS NO CONTEXTO DA INDÚSTRIA TÊXTIL E DO VESTUÁRIO}

Inovação vem sendo tema de pesquisas em diferentes áreas, principalmente por sua importância no que se refere a estratégias entre empresas. É considerada crucial para o seu desenvolvimento, visto que o mercado se tornou muito competitivo e os clientes cada vez mais exigentes (BUCHELE et al., 2017). Em virtude da globalização dos negócios a inovação se tornou de extrema importância para o desenvolvimento tecnológico e para a competitividade em virtude da grande concorrência dos setores (FEITOSA et al., 2014).

Segundo Freire (2015) as organizações inovadoras são capazes de obter um grande desempenho por meio de seu conhecimento, experiência e desempenho tecnológico, criando assim produtos e serviços, que divergem dos já existentes no mercado, a partir da recombinação de ideias antigas com novas ideias. Nesse sentido Britto, Kitazawa e Pepece (2019), salientam que muito do que as empresas buscam se diferenciar está relacionado a expectativa dos consumidores em relação a itens de tecnologia. A inovação não é uma estratégia apenas de grandes empresas, mas sim pode ser utilizada por pequenas e médias pelo fato de ela contribuir para seu desenvolvimento, expansão e aumentar a lucratividade (SILVA NÉTO; TEIXEIRA, 2014).

Um dos principais motivos que levam as empresas a buscarem pela inovação é o de se diferenciarem no mercado. Isso se dá devido a vasta competitividade e concorrência de produtos, bens e serviços. A sobrevivência de uma empresa está intimamente ligada ao que ela tem de diferente a ofertar de seus concorrentes (BRITTO; KITAZAWA, PEPECE, 2019). De modo geral as empresas que mais ganham 
espaço são as que se utilizam da inovação em todos os seus âmbitos (CARMONA; PARISOTTO, 2017). A inovação deve, ainda, ser promovida e estimulada entre os colaboradores de uma empresa.

Uma das estratégias para a inovação é o aprofundamento do conhecimento. Novas ideias são estimuladas para que a organização aumente a capacidade de criatividade e identifique as possibilidades no mercado. Para isso é necessário o domínio de vertentes específicas do mercado, levando em consideração a eficiência e eficácia atuante de uma organização (PADILHA et al., 2016). Nesse sentido outra estratégia importante são os estudos do mercado potencial, invenção ou concepção do produto básico, projeto detalhado e teste, reprojeto e produção, distribuição e comercialização.

A inovação faz parte de um conjunto de ações criada por pesquisas e interações entre as organizações e os gestores. Nesse sentido uma estratégia para a inovação é a comunicação com os fornecedores e clientes, averiguando a falta e o espaço para a implementação do novo no mercado, o engajamento da equipe com comprometimento e treinamento, desde o processo criativo, seleção de materiais, escolha de fornecedores e design, integrando a equipe para a produção de novos métodos e visões para a inovação (CARMONA; PARISOTTO, 2017; BRITTO; KITAZAWA, PEPECE, 2019). Isso pode ser feito tanto por meio de uma comunicação interna eficiente, como pelo uso de instrumentos adequados de transmissão da informação.

Contudo encontra-se algumas dificuldades para a inovação como o pouco conhecimento técnico, a dependência de fornecedores, pouco investimento em tecnologia, materiais desatualizados e funcionários desqualificados (SILVA NÉTO; TEIXEIRA, 2014). A necessidade de inovar vem principalmente da exigência dos consumidores e da necessidade das empresas se sustentarem no mercado. Esse fator contribui para que a empresa desenvolva suas capacidades.

As empresas inovadoras alcançam mais lucros que as empresas não inovadoras (SILVA NÉTO, 2014). O desempenho inovador de organizações têxteis pode ser avaliado pelo custo e eficiência de seus produtos, com a melhoria do processo da fabricação obtendo assim uma qualidade superior (PADILHA et al., 2016). Sendo assim, espera-se que, quanto maior o nível de inovação das empresas, mais lucros serão alcançados por elas.

No contexto têxtil e do vestuário ela se mostra importante uma vez que esse setor é composto por uma grande fragmentação de processos e cadeia de fornecimento dispersa (SILVA et al., 2018). A inovação em si propõe o envolvimento de pessoas, e estímulo por parte dos gestores. Pode ser 
altamente associada ao desenvolvimento de produtos, como no caso da indústria têxtil e do vestuário, e ou a melhoria de processos com vistas à competitividade (CARMONA, PARISOTTO, 2017).

\subsection{BREVE CONTEXTO DA INDÚSTRIA TÊXTIL E DE VESTUÁRIO}

Em termos de gestão a cadeia produtiva têxtil e de vestuário pode ser considerada uma das mais organizadas. Isso se deve ao fato de que ela é extensa e composta por diferentes etapas produtivas. Da produção das fibras, passando pela tecelagem, até que o produto esteja disponível para o consumidor final, há ainda os processos de transporte e produção (KACHBA: HATAKEYAMA, 2015). Apesar da cadeia têxtil estar ligada a produção das fibras, tecelagem e acabamento dos tecidos e a do vestuário realizar a produção do produto em si, ambas se convergem, podendo até mesmo serem consideradas como pertencentes à mesma cadeia produtiva (ABIT, 2019).

Essa convergência se dá já que a primeira, supre a demanda gerada pela segunda - que é a que propriamente idealiza e produz os itens de vestuário - tornando isso uma indústria complexa e competitiva (BRANDÃO, 2012). O setor têxtil e de vestuário compõe uma grande parcela da indústria mundial, no Brasil ela é considerada a segunda maior da indústria de transformação. Por meio de seus produtos agrega valor cultural, social e econômico a alguns países e regiões, contribuindo para a formação e desenvolvimento local ou regional (ABIT, 2019).

A competitividade do setor está relacionada ao tempo, já que ambas são influenciadas pelas tendências de moda, que em geral são delineadas sobre as estações climáticas (SILVA et al., 2018). Isso contribui para uma indústria caracterizada por ênfase em processos criativos, necessidade de um amplo mix de produtos, diversidade de matérias-primas e curto ciclo produtivo e de produção (FINARDI; SILVA; RADOS, 2016; SILVA et al., 2018). Desse modo esse tipo de indústria necessita buscar alternativas no que se refere a melhoria de produtos e processos.

Considerando que o tempo de produção de uma coleção de vestuário é em torno de 20 a 40 semanas, dependendo do tipo de comercialização, que o processo de seleção de materiais deve ser muito antes do início do desenvolvimento (em média um ano antes), ambas as indústrias necessitam de processos enxutos, melhoria no desenvolvimento de produtos e decisões rápidas e acertáveis para lidar com o tempo de produção e com a competitividade do setor (SEN, 2008; KACHBA; HATAKEYAMA, 2015; SILVA, 2017; SILVA et. al., 2018). 
Deste modo observa-se que no contexto têxtil e de vestuário a inovação é uma importante ferramenta que pode contribuir para a melhoria nos processos de produção, no desenvolvimento de produtos, na tomada de decisões, já que ela está também ligada a melhoria de algo que já vem sendo feito.

\section{METODOLOGIA}

Esta pesquisa quanto à forma de abordagem do problema é qualitativa, já que está fundamentada em aspectos teóricos e o instrumento de coleta não resulta em índices estatísticos e ou numéricos. Quanto ao tipo é exploratória, já que teve como objetivo proporcionar a verificação de aspectos, por meio de revisão bibliográfica tornando o problema de pesquisa mais visível (GIL, 2010; MARCONI; LAKATOS, 2014). Como técnica para a coleta de dados foi utilizado a revisão sistemática de literatura, que teve como objetivo encontrar na literatura disponível publicações com relevância científica sobre o assunto aqui estudado.

Para isso foram selecionadas as bases de busca científica Periódicos Capes (PT/ING) e Scopus - (ING), por serem fontes com alto teor de publicações científicas. A partir da escolha das bases, foi selecionado quatro termos para busca sendo: Inovação + vestuário; Inovação + têxtil; Innovation + clothing e; Innovation + textile. A seleção dos artigos foi feita a partir de temas relacionados à pesquisa e disponibilizados na integra. Os artigos distantes ao tema não foram utilizados. Após essa seleção foise compactando as informações relevantes para a pesquisa, em seguida iniciou-se a junção das informações para o encontro do objetivo aqui proposto. O Quadro 1 mostra a quantidade de artigos encontrados por base de busca e por indicador de pesquisa. Como recorte temporal a pesquisa foi limitada a encontrar publicações entre 2014 e 2019.

Quadro 1: Quantidade de publicações encontradas por base de pesquisa.

\begin{tabular}{|c|c|c|c|}
\hline Base de Busca & Indicador de Pesquisa & $\begin{array}{l}\text { Quantidade de Publicações } \\
\text { Encontradas }\end{array}$ & $\begin{array}{l}\text { Quantidade de } \\
\text { Publicações Utilizadas }\end{array}$ \\
\hline \multirow{2}{*}{$\begin{array}{l}\text { Periódicos } \\
\text { Capes (PT/ING) }\end{array}$} & $\begin{array}{l}\text { Inovação + vestuário } \\
\text { Innovation + clothing }\end{array}$ & 87 & 3 \\
\hline & $\begin{array}{l}\text { Inovação + têxtil } \\
\text { Innovation + textile }\end{array}$ & 113 & 11 \\
\hline \multirow{2}{*}{ Scopus - (ING) } & Innovation + clothing & 106 & 1 \\
\hline & Innovation + textile & 10 & 2 \\
\hline
\end{tabular}

Fonte: A partir dos dados da pesquisa (2019). 
Para além dos aspectos teóricos, verificou-se por meio de uma análise posterior a verificação do Quadro 1, produtos e ou processos inovadores existentes no contexto do vestuário, propriamente dito, que já estão sendo implantados em empresas do setor. A análise foi por meio on-line utilizandose da base de busca Google.

\section{APRESENTAÇÃO DOS RESULTADOS}

Para compor os resultados desta pesquisa, a análise sistemática de literatura priorizou os trabalhos que tratam sobre algum aspecto de inovação no contexto têxtil e de vestuário. Assim os trabalhos selecionados apresentam-se no Quadro 2.

Quadro 2: Relação das publicações encontradas por autor e título.

\begin{tabular}{|c|c|}
\hline Autor & Título \\
\hline Feitosa et al., (2014). & $\begin{array}{l}\text { Desenvolvimento e adoção da inovação em uma microempresa de confecções localizada } \\
\text { em Campina Grande - PB }\end{array}$ \\
\hline Bragança et al., (2016). & Marketing, criatividade e inovação em unidades de informação. \\
\hline $\begin{array}{l}\text { Silva Néto e Teixeira } \\
\text { (2014). }\end{array}$ & $\begin{array}{l}\text { Inovação de Micro e Pequenas Empresas: Mensuração do Grau de inovação de empresas } \\
\text { Participantes do Projeto Agentes Locais de inovação. }\end{array}$ \\
\hline Klein et al., (2016). & $\begin{array}{l}\text { Capacidade de aprendizagem organizacional e desempenho inovador: Percepção dos } \\
\text { atores de uma empresa. }\end{array}$ \\
\hline $\begin{array}{l}\text { Oliveira e Epaminondas } \\
\text { (2014). }\end{array}$ & $\begin{array}{l}\text { Conhecimento, inovação e estratégia competitiva: um estudo no setor atacadista da } \\
\text { moda. }\end{array}$ \\
\hline Torres e Silva (2014). & A inovação nas empresas de Caruaru-PE. \\
\hline Kim et al., (2018). & $\begin{array}{l}\text { Thermally insulating, fire-retardant, smokeless and flexible polyvinylidene fluoride } \\
\text { nanofibers filled with silica aerogels. }\end{array}$ \\
\hline $\begin{array}{l}\text { Bloomfield e Borstrock } \\
\text { (2018). }\end{array}$ & Modeclix The additively manufactured adaptable textile. \\
\hline Mohammad e An (2018). & Efficient Dyeing Mechanism of Cotton/Polyester Blend Knitted Fabric. \\
\hline $\begin{array}{l}\text { Reichert, Camboim e } \\
\text { Zawislak (2015). }\end{array}$ & Capacidades e trajetórias de inovação de empresas Brasileiras. \\
\hline $\begin{array}{l}\text { Thorne, Thorne e Albor } \\
\text { (2017). }\end{array}$ & Inovação, Indústrias Cultural e Desenvolvimento Local \\
\hline $\begin{array}{l}\text { Grisales, Restrepo e Alonso } \\
\text { (2015). }\end{array}$ & $\begin{array}{l}\text { Modelo para gestionar el conocimiento en el sector textil de Medellín, empleando } \\
\text { dinámica de sistemas }\end{array}$ \\
\hline Oliveira et al., (2016). & $\begin{array}{l}\text { As relações entre eco-inovacões e o impacto na performance empresarial: uma pesquisa } \\
\text { empírica na indústria têxtil brasileira }\end{array}$ \\
\hline
\end{tabular}




\begin{tabular}{|l|l|}
\hline Maia, Alves e Leão, (2014). & $\begin{array}{l}\text { Perspectivas individuais sobre a necessidade de mudança: estudo de caso na Indústria } \\
\text { Têxtil e do Vestuário Portuguesa. }\end{array}$ \\
\hline $\begin{array}{l}\text { Carmona e Parisotto } \\
\text { (2017). }\end{array}$ & $\begin{array}{l}\text { Capacidades dinâmicas e inovação } \\
\text { colaborativa: estudo de caso no setor têxtil catarinense. }\end{array}$ \\
\hline $\begin{array}{l}\text { Bukahari, Cueto e Ponce } \\
\text { (2018). }\end{array}$ & Developing a national programme for textiles and clothing recovery. \\
\hline $\begin{array}{l}\text { Britto, Kitazawa e Pepece } \\
\text { (2019). }\end{array}$ & O uso da nanotecnologia na indústria têxtil para inovar na moda gestante. \\
\hline
\end{tabular}

Fonte: A partir dos dados da pesquisa (2019).

O Quadro 2 apresenta os 16 artigos que possuem relação ao escopo desta pesquisa, estando eles diretamente ligados a inovação no contexto têxtil e do vestuário. Nota-se que as publicações são apresentadas entre os anos de 2013 e 2018. De acordo com os títulos, observa-se diferentes perspectivas de pesquisa tanto na indústria têxtil quanto na de vestuário. Também foi possível verificar uma grande quantidade de publicações em português e que esses estudos intencionam investigações no próprio País, a partir de elementos já existentes nos ambientes investigados. Como as publicações de Silva Néto e Teixeira (2014), que mensuram o grau de inovação nas micro e pequenas empresas, e de Reichert, Camboim e Zawislak, (2015) que identificam as capacidades de inovação em empresas brasileiras.

A partir disso com a finalidade de averiguar o que a literatura vem tratando como aspectos de inovação no setor têxtil e de vestuário, analisou-se os objetivos de pesquisa dos artigos encontrados. Os resultados são apresentados no Quadro 3.

Quadro 3: Relação das publicações encontradas por autor e objetivo.

\begin{tabular}{|l|l|}
\hline Autor / Ano & Objetivo de Pesquisa \\
\hline $\begin{array}{l}\text { Feitosa et al., } \\
\text { (2014). }\end{array}$ & $\begin{array}{l}\text { Verificar os processos de desenvolvimento e adoção da inovação em uma microempresa de } \\
\text { confeç̃ões masculinas infantis, situada em Campina Grande, Paraíba, evidenciando as etapas do } \\
\text { processo de desenvolvimento e adoção da inovação. }\end{array}$ \\
\hline $\begin{array}{l}\text { Bragança et al., } \\
\text { (2016). }\end{array}$ & $\begin{array}{l}\text { Apresentar os conceitos de marketing, criatividade e inovação aplicados ao mundo dos arquivos, } \\
\text { estabelecendo um diálogo entre as áreas de conhecimento, numa vertente de aprendizagem e } \\
\text { intercâmbio de saberes, que viabilize a construção de novos conhecimentos e a adoção novas } \\
\text { práticas de gestão em unidades de informação. }\end{array}$ \\
\hline $\begin{array}{l}\text { Silva Néto e } \\
\text { Teixeira (2014). }\end{array}$ & \begin{tabular}{l} 
Mensurar o grau de inovação de micro e pequenas empresas sergipanas. \\
\hline Klein et al., (2016).
\end{tabular} \\
$\begin{array}{l}\text { Verificar como a capacidade de aprendizagem organizacional afeta o desempenho inovador em } \\
\text { uma empresa têxtil. }\end{array}$ \\
\hline
\end{tabular}




\begin{tabular}{|c|c|}
\hline $\begin{array}{l}\text { Oliveira e } \\
\text { Epaminondas } \\
\text { (2014). }\end{array}$ & $\begin{array}{l}\text { Descrever como o conhecimento, inovação e estratégias competitivas são tratados no contexto } \\
\text { das organizações do setor atacadista da moda mineira }\end{array}$ \\
\hline $\begin{array}{l}\text { Torres e Silva } \\
\text { (2014). }\end{array}$ & $\begin{array}{l}\text { Colher evidências empíricas da percepção dos empreendedores do município de Caruaru-PE } \\
\text { sobre inovação. }\end{array}$ \\
\hline Kim et al., (2018). & $\begin{array}{l}\text { Propor um processo de electrospinning para fabricar sílica aerogel-fi nano polímero, modificando } \\
\text { o processo química gel para a síntese de aerogel de sílica. }\end{array}$ \\
\hline $\begin{array}{l}\text { Bloomfield e } \\
\text { Borstrock (2018). }\end{array}$ & $\begin{array}{l}\text { Abordar os desafios através da combinação de ambas as técnicas de construção tradicionais, com } \\
\text { tecnologias avançadas de manufatura. }\end{array}$ \\
\hline $\begin{array}{l}\text { Mohammad e An } \\
\text { (2018). }\end{array}$ & $\begin{array}{l}\text { Descobrir um processo de tingimento alternativa para reduzir o consumo de água, o tempo de } \\
\text { processo e o custo de produção substituindo processo de tingimento convencional. }\end{array}$ \\
\hline $\begin{array}{l}\text { Reichert, Camboim } \\
\text { e Zawislak (2015). }\end{array}$ & $\begin{array}{l}\text { Identificar as capacidades de inovação de empresas industriais brasileiras e, com isso, explicitar } \\
\text { suas trajetórias de inovação. }\end{array}$ \\
\hline $\begin{array}{l}\text { Thorne, Thorne e } \\
\text { Albor (2017). }\end{array}$ & $\begin{array}{l}\text { Este artigo analisa o setor têxtil e de vestuário e o potencial cultural da cidade de Barranquilla, } \\
\text { para a promoção de um sistema de moda baseado em uma proposta de valor de produtos com } \\
\text { identidade territorial. }\end{array}$ \\
\hline $\begin{array}{l}\text { Grisales, Restrepo } \\
\text { e Alonso (2015). }\end{array}$ & $\begin{array}{l}\text { Avaliar a relação de causalidade entre a gestão do conhecimento e as capacidades de inovação } \\
\text { tecnológica, e efeito desta relação sobre os resultados operacionais do setor têxtil na cidade de } \\
\text { Medellín. }\end{array}$ \\
\hline $\begin{array}{l}\text { Oliveira et al., } \\
\text { (2016). }\end{array}$ & $\begin{array}{l}\text { Investigar as inter-relações entre três tipos de ecoinovação (processo, produto, organizacional) e } \\
\text { o seu impacto na performance empresarial. Com o estudo no setor têxtil que amplia a discussão } \\
\text { sobre a interdependência das relações coevolutivas entre os diferentes tipos de ecoinovacão. }\end{array}$ \\
\hline $\begin{array}{l}\text { Maia, Alves e Leão, } \\
\text { (2014). }\end{array}$ & $\begin{array}{l}\text { Perceber de uma forma individual a necessidade de mudança e as suas causas, em um estudo de } \\
\text { caso na Indústria Têxtil e do Vestuário. }\end{array}$ \\
\hline $\begin{array}{l}\text { Carmona e } \\
\text { Parisotto (2017). }\end{array}$ & $\begin{array}{l}\text { Investigar como se desenvolvem as capacidades dinâmicas e a inovação colaborativa na } \\
\text { manufatura de têxteis. }\end{array}$ \\
\hline $\begin{array}{l}\text { Bukahari, Cueto e } \\
\text { Ponce (2018). }\end{array}$ & $\begin{array}{l}\text { Examinar o programa nacional francês para a gestão de têxteis e vestuário pós-consumo através } \\
\text { de um estudo de caso. }\end{array}$ \\
\hline $\begin{array}{l}\text { Britto, Kitazawa e } \\
\text { Pepece (2019). }\end{array}$ & $\begin{array}{l}\text { Entender a forma como o uso da nanotecnologia associada à moda ajudou uma empresa do setor } \\
\text { têxtil a inovar e atender uma demanda dos consumidores. }\end{array}$ \\
\hline
\end{tabular}

Fonte: A partir dos dados da pesquisa (2019).

Ao analisar os objetivos apresentados no Quadro 3, percebeu-se a divisão de dois grupos. O primeiro e que apresenta o maior número de publicações (14) está ligado a ideia de investigação ou averiguação. Isso pode sugerir que a inovação no contexto têxtil e de vestuário ainda é algo relativamente novo e que ainda há a busca por melhor entendê-la nesse contexto. Outro grupo, menor com apenas duas publicações, está relacionado a propostas de inovação. O que a área acadêmica vem realizando, com base no que se observa no Quadro 3, é explorando esse ambiente para então apontar o que já vem sendo realizado. 
Observa-se no artigo de Kim et al., (2018) a proposta de um processo tecnológico para o desenvolvimento de um tecido derivado de nano polímero e no artigo de Mohammad e An (2018), que aborda um processo que reduz o consumo de água. Esses trabalhos apresentam resultados importantes no que se trata de inovação. Kim et al., (2018), apresentam, ainda, a viabilidade da implantação de produtos em aerogel de sílica para o uso no dia a dia. Mohammad e An (2018) resultam em um material com boa solidez e propriedades ligadas a usabilidade aceitáveis.

Ainda de acordo com o Quadro 3 há relevância no artigo de Silva Néto e Teixeira (2014), que concluiram o baixo grau de inovação nas empresas Sergipanas. O artigo de artigo de Oliveira e Epaminondas (2014), que demonstra que no setor têxtil e de vestuário existem as imitações criativas, no entanto há espaço para o desenvolvimento de produtos e processos inovadores. Autores como Alves e Leão (2014) e Thorme, Thorme e Albor (2017), discorrem sobre a importância da inovação. Kim et al., (2018), Bloomfield e Borstrock (2018) e Mohammad e An (2018), mostram a temática de novas fibras feitas de nanopolímeros.

A partir da análise desses grupos e dos trabalhos presentes em cada um deles observou-se alguns pontos que vêm sendo tratados pela indústria têxtil e de vestuário no que se trata de conceito de inovação. O primeiro é a mistura de matérias-primas e o desenvolvimento de produtos exclusivos (OLIVEIRA; EPAMINONDAS, 2014). Um exemplo disso é o nanopolímero, material chamado de Modeclix específico para as inovações tecnológicas na indústria têxtil, o material é aplicado no vestuário como isolante térmico. Sua superfície varia sendo utilizado também em aplicações aeroespaciais como isolamento térmico para sondas espaciais (KIM et al., 2018).

Esse material foi produzido utilizando polímeros como a poliamida e possui como característica a falta de flexibilidade sendo limitado para algumas funções específicas. Estudos estão sendo feitos para viabilizar esse têxtil na busca de ser utilizado futuramente em luvas, sapatos entre outras peças do vestuário, por meio de técnicas de condução e aplicação de outras tecnologias (KIM et al., 2018). Ele pode ser impresso em folhas têxteis e tingido, criando assim maior versatilidade para o vestuário e acessórios de moda.

O Modeclix está interligado à fatores econômicos no que diz respeito ao ciclo de vida dos produtos, contribuindo para que uma peça do vestuário se readapte à novas peças (BLOOMFIELD; BORSTROCK, 2018). O material envolve a necessidade de reduzir os recursos de produção, extensão do produto e sua vida útil, apresentando assim uma inovação em impressão 3D, atendendo a práticas de produção sustentável, com economia circular (BLOOMFIELD; BORSTROCK, 2018) 
Um dos principais desafios da produção desse material é o tamanho das máquinas para impressão. Para solucionar isso, ao criar um produto de vestuário em tamanho real, é necessário adequar o tamanho das máquinas, o que possibilitaria uma produção em maior escala. As primeiras peças foram criadas em tamanho reduzido e sem costura. Elas podem ser totalmente personalizadas, removendo ou adicionando partes e se adaptando ao corpo, de acordo com comprimento altura e largura. Em geral são tingidos com corantes próprios para sintéticos, os mesmos disponíveis nas indústrias (BLOOMFIELD; BORSTROCK, 2018).

Kim et al., (2018) apresenta outro material que trata de inovação, um tecido de carvão ativado, que possui alta taxa de absorção, estabilidade, flexibilidade. Esse têxtil tem sido comercializado principalmente para armas nucleares, biológicas e roupa de proteção química. Alguns materiais foram utilizados como precursores desta fibra, como: rayon de viscose, de acetato, e poliacrilonitrilo. Atualmente algumas peças de vestuário de proteção já foram produzidas utilizando os tecidos de carbono, que contém um adesivo polímero e sobreposto por outra camada de tecido não tecido juntados por uma técnica de fusão (KIM et al., 2018).

O custo para a produção desse tecido ainda é alto e alguns estudos ocorrem na tentativa de o aliar a outras fibras celulósicas para a formação de tecidos com efeito de seda artificial e de viscose. Sendo eles desenvolvidos por meio de estabilização térmica e carbonização. Nesse processo o material se torna inerente à chama e pode ser aplicado em produtos como meias, lenços, capuzes, máscaras, entre outras (KIM et al., 2018). Britto, Kitazawa e Pepece (2019), apresentam os resultados de uma investigação sobre o uso da nanotecnologia em produtos de vestuário direcionados a gestantes. 0 produto possui ação repelente ao mosquito transmissor de doenças como a dengue e zika vírus.

Em virtude da problemática do consumo elevado, e que vai ao encontro da inovação de processos, foi desenvolvido pela empresa Toyota no final da Segunda Guerra Mundial um programa de ferramentas e técnicas para gestão de processos de eliminação de todas as atividades que não acrescentam valor e culminem em desperdícios denominado de Lean Production (LP). Esse programa vem sendo utilizado pela indústria têxtil no sentido de melhoria nos processos de produção resultando na inovação de processos e produtos.

A implantação desse programa implica na mudança de mentalidade, responsabilidade e competência de todos os envolvidos. Os projetos LP concentram-se na eliminação ou redução de atividades que um cliente final não paga: retrabalho, inspeção, inventário, filas ou tempo de espera, transporte de 
materiais ou produtos, movimento excessivos e outras etapas do processo sem valor acrescentado (MAIA; ALVES; LEÃO, 2014).

Apesar de o que se encontrou até aqui se mostrar como elementos de inovação, isso se mostra como mais concreto na possibilidade de novos materiais têxteis e, ou no desenvolvimento de processos que buscam minimizar atividades, processos e recursos. Deste modo houve um aprofundamento na pesquisa para encontrar, possibilidades ou existência de ações inovadoras, no contexto do vestuário propriamente dito.

\subsection{POSSIBILIDADES DE INOVAÇÃO NO CONTEXTO DO VESTUÁRIO}

Em se tratando de inovação no vestuário esta pesquisa encontrou uma linha de produtos com preceitos sustentáveis, desenvolvida pela empresa A Casa Rosa. Trata-se de produtos produzidos com materiais desfibrados - retalhos desfiados e transformados em uma nova malha íntegra. A produção dessa linha economiza em torno de $80 \%$ da água necessária para o processo de produção e tinturaria. Os produtos são feitos sob encomenda, já que se trata de um processo altamente complexo e exclusivo (CARMONA; PARISOTTO, 2017).

Outro fator de inovação encontrado é o da política extensiva de responsabilidade do produtor (EPR), que é direcionada para melhorar o setor de resíduos têxteis para os produtores de moda de modo a adotar o eco-design para práticas de reciclagem. Isso contribui para as empresas se tornarem responsáveis pela reciclagem ou eliminação adequada dos seus produtos. As empresas de vestuário coletam roupas já utilizadas e dão um voucher de desconto para o consumidor (BUKHARI; CALLEGO; CUETO, 2018).

Algumas das roupas recolhidas são doadas, outras vendidas em aplicativos virtuais, e as demais destinadas para empresas de reciclagem. Todos os itens escolhidos são cadastrados, registrados e classificados antes das doações ou vendas. Em seguida, os materiais são classificados e armazenados, estando prontos para serem despachados (BUKHARI, CALLEGO, CUETO, 2018). Isso contribui para que o nível de descarte de peças do vestuário, seja minimizado.

Propriamente no sentido de produto, tem-se a empresa Megadose, localizada no estado do Paraná, que utilizou um produto têxtil com nanotecnologia chamado de linha Care. Isso fez com que o produto em si além de sua função prática (vestir) se aproximasse mais de seus consumidores por oferecer um efeito tecnológico - ação repelente contra o mosquito transmissor de doenças como a dengue e o zika vírus (BRITTO; KITAZAWA; PEPECE, 2019). 
Observa-se que alguns aspectos de inovação encontrados no contexto da indústria têxtil e na indústria do vestuário estão ligados a produtos e serviços que possuem preceitos sustentáveis, e que se adequam a processos para utilização de recursos naturais. Visto que a inovação faz com que estas empresas que a utilizam se destaquem no mercado, através de suas estratégias, visão, criatividade e processos.

\section{CONCLUSÃO}

Diante da pesquisa aqui apresentada observou-se que a inovação trata de um conjunto de ações, práticas e teóricas, que visam a melhoria de algo já existente ou que crie valor para os envolvidos. $\mathrm{O}$ contexto têxtil e de vestuário é reconhecido por sua importância estratégica no contexto econômico brasileiro, no entanto trata-se de um setor altamente competitivo onde a inovação apesar de necessária, ainda é tida como algo não muito presente no cotidiano dessas empresas.

A análise sistemática de literatura possibilitou verificar junto à literatura da área o que vem sendo discutido sobre essa temática. Primeiramente é possível afirmar que o que vem sendo discutido pelo âmbito científico está concentrado em dois grupos: um ligado a apenas a investigação da inovação e outro com a aplicação da inovação em si. Isso mostra que possivelmente o conceito de inovação nessas indústrias é tido como algo novo, ainda motivado pela sua compreensão.

Em análise a esses dois grupos tem-se como destaque o uso da mistura de nanopolímeros e a fibra de poliamida, que resultou em um tecido chamado Modeclix. Esse material vem sendo utilizado em roupas, como isolante térmico e, em projetos aeroespaciais. Nesse mesmo sentido mostra-se como relevante o desenvolvimento de um tecido de carvão ativado, de alta taxa de absorção, estabilidade e flexibilidade, que vem sendo utilizado em armas nucleares, biológicas e em roupas de proteção química. E por último um aspecto ligado à sustentabilidade, visto que os processos de desenvolvimento têxteis consomem grandes quantidades de água e energia. Desenvolvido pela empresa Toyota no final da segunda guerra mundial, um programa de ferramentas e técnicas para gestão de processos de eliminação de processos que não acrescentam valor e desperdícios chamado LP, vem sendo utilizado para melhoria dos processos têxteis.

Em avanço aos resultados encontrados verificou-se especificamente no contexto do vestuário o que vem sendo tratado quando se fala em inovação. Encontrou-se uma linha de produtos com preceitos sustentáveis, produzidos com materiais desfibrados que resultam em um novo tecido. Observou-se, também, um aspecto de inovação interligado a preceitos sustentáveis, que é a política extensiva de 
responsabilidade do produtor (EPR) que está diretamente ligada à utilização dos resíduos têxteis e a preocupação com seu descarte. E o uso da nanotecnologia em produtos de vestuário para gestantes.

Após a realização da pesquisa, conclui-se que há gaps práticos e teóricos no que se trata de inovação no contexto da indústria têxtil e de vestuário no Brasil, como a utilização de tingimentos $100 \%$ ecológicos e a inexistência de utilização de novas fibras, principalmente advindas de produtos naturais, com polpas de frutas ou bagaços. Por fim o objetivo da pesquisa foi atendido em investigar sobre os diferentes aspectos de inovação encontrados no contexto têxtil e vestuário, identificando que há possibilidades em pesquisas teóricas e práticas na busca por novos processos e produtos inovadores. 


\section{REFERÊNCIAS}

ASHOK, M.; NARULA, R.; MARTINEZ-NOYA, A. How do collaboration and investments in knowledge management affect process innovation in services? Journal of Knowledge Management, Sonning Commom, v. 20, n.5, p. 1004-1024, 2016.

ASSOCIAÇÃO BRASILEIRA DAS INDÚSTRIAS TÊXTEIS E DE VESTUÁRIO (ABIT). Perfil do Setor: Dados gerais do setor atualizados em 2019, referentes ao ano de 2018. Disponível em: <http://www.abit.org.br/cont/perfil-do-setor> Acesso em 15/08/2019.

BALESTRIN, A.; VARGAS, L. M.; FAYARD, P. Knowledge creation in small-firm network. Journal of Knowledge Management, v. 12, n. 2, p. 94-106, 2008.

BLOOMFIELD, M; BORSTROCK, S. Modeclix. The additively manufactured adaptable textile. Materials Today Communications, v. 16. p. 212-216, 2018.

BRASIL, M. V. de O.; ABREU, M. C. S; FILHO, J. C. L. da S., LEOCÁDIO, A. L. Relationship between ecoinnovations and the impact on business performance: an empirical survey research on the Brazilian textile industry. Revista de Administração, São Paulo, v. 51 n.3, p. 276-287, 2016.

BRANDÃO. C. A indústria brasileira de têxteis-vestuário: uma análise da competitividade, no contexto atual. Campinas, 2012. Revista ModaPalavra e-Periódico, v. 8, n.15, 2015.

BRITTO, L. R. G. D.; KITAZAWA, H. M.; PEPECE, O. M. C. O uso da nanotecnologia na indústria têxtil para inovar na moda gestante. Revista Brasileira de Gestão e Inovação, Caxias do Sul, v. 6, n. 2, p. 168193, 2019.

BUCHELE, G. T. et al. Características da adoção de métodos, técnicas e ferramentas para inovação em organizações catarinenses. Navus, [s/l], v. 7, n. 3, p. 104-112, 2017.

BUKHARI, M. A. CALLEGO, R. C.; CUETO, E. P. Developing a national programme for textiles and clothing recovery. Waste Management \& Research, v. 36, n. 4, p. 321-331, 2018.

CARMONA, L. J. De M.; PARISOTTO, I. R. dos S. Capacidades dinâmicas e inovação colaborativa: estudo de caso no setor têxtil catarinense. Revista Ibero-Americana de Estrategia, vol. 16, n. 4, 2017.

FEITOSA, M. J. da S.; SANTOS, R. da S.; BEZERRA, V. H. B.; NOGUEIRA, J. M. Desenvolvimento e adoção da inovação em uma microempresa de confecções localizada em Campina Grande - PB. Revista Geintec, São Cristóvão, v. 4, n. 3, 2014.

FINARDI, C.; SILVA, E. L. D.; RADOS, G. J. V. O fluxo da informação no processo de design de moda: uma análise aplicada em pequenas empresas de confecção da grande Florianópolis - Santa Catarina. Perspectivas em Gestão \& Conhecimento, João Pessoa, v. 6, n. 2, p. 134-152, jul/dez 2016.

FUJITA, R.; JORENTE, M. A Indústria Têxtil no Brasil: uma perspectiva histórica e cultural. São Paulo, 2015. Moda Palavra, v. 8, n. 15, 2015.

FREIRE, O. B. De L. Marketing, criatividade e inovação em unidades de informação. Revista Brasileira de Marketing, v. 15, n. 2, 2016.

GIL, A. C. Como Elaborar Projetos de Pesquisa. 5ạ. Ed. São Paulo: Atlas, 2010. 
KACHBA, Y. R.; HATAKEYAMA, K. Competence for Product Development Management in Clothing Firms. International Association for Management of Technology. IAMOT, p. 1863-1876, 2015. Disponível em: <http://www.iamot2015.com/2015proceedings/documents/P253.pdf>. Acesso em: 25 agosto 2018.

KIM, Y.; KIMB, H; JOA, S. Um; KIMC, S. Y; YANGB, B.J; CHOB, J; LEEA, S; CHAB, Ji E. Thermally insulating, fire-retardant, smokeless and flexible polyvinylidene fluoride nanofibers filled with silica aerogels. Chemical Engineering Journal, v. 351, p. 473-481, 2018.

MAIA, L. C.; ALVES, A.; LEÃO, C. P. Perspectivas individuais sobre a necessidade de mudança: estudo de caso na Indústria Têxtil e do Vestuário Portuguesa. RISTI, Porto, n. 2, p. 115-127, 2014.

MACCHION, L.; MORETTO, A.; CANIATO, F.; CARIDI, M.; DANESE, P.; VINELLI, A. Production and supply network strategies within the fashion industry. International Journal of Production Economics, Amsterdam, v. 150, p. 1012-1019, Sept. 2014.

MARCONI, M. D. A; LAKATOS, E. M. Fundamentos de Metodologia Científica. 6ạ ed. São Paulo: Atlas, 2006.

NÉTO, A. T. S.; TEIXEIRA, R. M. Inovação de micro e pequenas empresas: mensuração do grau de inovação de empresas participantes do Projeto Agentes Locais de Inovação. Brazilian Business Review, v. 11, n. 4, p. 1-29, 2014.

OLIVEIRA, P. H. D.; EPAMINONDAS, M. E. R. Conhecimento, Inovação e Estratégia competitiva: um estudo no setor atacadista da moda. Revista Eletrônica de Estratégia \& Negócios, Florianópolis, v. 7, n. 1, p. 82-104, 2014.

PADILHA, C. K.; WOJAHN, R. M.; GOMES, G.; MACHADO, D. Del P. N. Capacidade de aprendizagem organizacional e desempenho inovador: Percepção dos atores de uma empresa têxtil. Race, Joaçaba, v. 15, n. 1, p. 327-350, jan./abr. 2016.

REICHERT, F. M.; CAMBOIM, G. F.; ZAWISLAK, Paulo Antônio. Capacidades e trajetórias de inovação de empresas brasileiras. RAM, Rev. Adm. Mackenzie, São Paulo, v.16, n.5, p. 161-194, 2015.

SEN, A. The US Fashion Industry: A supply chain review. Int. J. Production Economics, [s.I], p. 571 593, 2008.

SILVA, M. J. A Gestão do Conhecimento no processo de compras de matérias-primas e complementos em uma empresa do setor de moda e vestuário da região Noroeste do Paraná. 128 f. (Dissertação Mestrado) - Programa de Pós-Graduação em Gestão do Conhecimento nas Organizações. Centro Universitário de Maringá. Maringá, 2017.

SILVA, M. J.; MENEGASSI, C. H. M.; SARTORI, R.; TENÓRIO, N. Knowledge management within the fashion and clothing industry: an investigation into the purchase processes within a company. International Journal of Development Research, [s/l], v. 08, n. 03, p. 19739-19743, Mar. 2018.

SILVA NÉTO, A. T.; TEIXEIRA, R. M. Inovação de Micro e Pequenas Empresas: Mensuração do Grau de Inovação. Brazilian Business Review, Vitória, v. 11, n. 4, p. 1-29, 2014.

TORRES, L.F.; SILVA, F. C.L. A inovação nas empresas de Caruaru-PE. Anais do III SINGEP e II S2IS - São Paulo, 2014. 


\section{Capítulo 5}

d.)

\section{AVALIAÇÃO ERGONÔMICA DO AMBIENTE CONTRUIDO: ESTUDO DO SETOR DE HEMODINÂMICA DE UM HOSPITAL UNIVERSITÁRIO À LUZ DA MEAC}

Waldelourdes de Melo Souto Maior

Marilande Carvalho de Andrade Silva

Marcelo Francisco Gomes

Alaíde Farias de Almeida Filha

Vilma Maria Villarouco Santos
Universidade Federal de Pernambuco

Universidade Federal de Pernambuco

Universidade Federal de Pernambuco

Universidade Federal de Pernambuco

Universidade Federal de Pernambuco 
Resumo: Estudo realizado na Hemodinâmica de um Hospital Universitário, utilizando a Metodologia Ergonômica para o Ambiente Construído (MEAC), proposta por Villarouco (2008), visando um diagnóstico de adequação do espaço aos seus usuários. Os resultados mostraram as reais necessidades de ajustes para o ambiente atender às demandas, a fim de alcançar os objetivos da Ergonomia.

Palavras-chave: Ergonomia, Hemodinâmica, Ergonomia do ambiente construído. 


\section{INTRODUÇÃO}

A hemodinâmica tem como principal atividade, a prestação de atendimento ao diagnóstico e terapia através da realização de exames por meio da radiologia endocardiovascular, recorrendo a cateteres e injeções de contraste, nos procedimentos como angioplastias, cateterismos, drenagens e embolizações terapêuticas. Procedimentos que são invasivos, não cirúrgicos e contribuem para um diagnóstico exato e indicação do tratamento mais adequado. A Hemodinâmica requer profissionais especializados e capacitados, onde o espaço físico é dotado de equipamentos, materiais e instalações de alta complexidade e tecnologia avançada.

Sob a ênfase da ergonomia do ambiente construído, os olhares se voltam para o ambiente físico e seu espectro analisa os diversos fatores que envolvem esse ambiente e sua influência no desempenho das atividades exercidas pelos seus usuários. Esta análise ultrapassa os limites da observação pura sobre a edificação em si, mas envolve fatores como dimensionamento, organização, layout, acessibilidade, iluminação, conforto térmico, cores, sensações percebidas, e outros condicionantes físicos que tenham influência sobre o trabalhador (VILLAROUCO, 2011).

O presente estudo foi realizado com o objetivo de avaliar o ambiente do serviço de Hemodinâmica de um Hospital Universitário na cidade do Recife -Pernambuco do ponto de vista ergonômico, a partir da Metodologia Ergonômica para o Ambiente Construído (MEAC), proposta por Villarouco (2008), que desenvolve uma abordagem ergonômica a fim de entender, avaliar, e modificar o ambiente e a interação continua com seu usuário.

\section{METODOLOGIA}

Trata-se de uma pesquisa exploratória e qualitativa, de cunho descritivo. A população usuária do local que participou da avaliação do ambiente foi constituída por 11 profissionais de enfermagem, de um universo de 25 que trabalha na hemodinâmica. A pesquisa foi realizada de julho a agosto de 2016.

A MEAC é desenvolvida por etapas agrupadas em cinco etapas gerais, sendo as três primeiras de avaliações físicas do ambiente, a quarta de entendimento da percepção do usuário sobre o espaço usado, está no bloco perceptivo, para finalmente, na etapa cinco, ter-se o diagnóstico e as recomendações:

Etapa 1 -Análise Global do Ambiente: nesta primeira etapa foi realizada pesquisa no local escolhido, inicialmente com observação assistemática, walkthrough, registro fotográfico e entrevista com os usuários; 
Etapa 2 -Identificação da Configuração Ambiental: onde foram levantados e registrados dados referentes ao ambiente físico, postos de trabalho, condições de temperatura, ventilação, iluminação, aspectos construtivos, de acessibilidade e de segurança. As medições foram feitas durante o turno de trabalho;

Etapa 3 -Avaliação do Ambiente em Uso: a partir da observação, os dados coletados foram representados em mapofluxogramas;

Etapa 4 -Percepção Ambiental do Usuário: esta etapa contemplou a análise das entrevistas e demonstrou as expectativas e impressões dos usuários do ambiente. A representação gráfica foi através da ferramenta Constelação de Atributos, idealizada por Moles (1968);

Etapa 5 -Por fim, com base na análise dos dados, foram tecidos o diagnóstico e indicada as recomendações e proposição de mudanças para atender às principais necessidades e insatisfações dos usuários.

\section{ANÁLISE ERGONÔMICA}

\subsection{ETAPA 1: ANÁLISE GLOBAL DO AMBIENTE}

O Hospital Universitário foi fundado em 1979, está localizado na cidade do Recife -PE. O setor de Hemodinâmica fica no 2 o andar do prédio do ambulatório, numa área construída de $296 \mathrm{~m}^{2}$ dividido em 26 ambientes e 10 postos de trabalho, é um setor fechado de acesso restrito, e proporciona à equipe multiprofissional a realização de exames de imagens através de radiação ionizante.

A Hemodinâmica funciona de segunda a sexta-feira das 7:00 as 19:00 h, com 38 profissionais (médicos, anestesistas, enfermeiros, técnicos e auxiliares de enfermagem, maqueiros, técnicos de radiologia, técnicos administrativos e auxiliares de serviços gerais). O ambiente é limpo, todavia apresenta má conservação, a iluminação é precária, o mobiliário e os equipamentos são antigos, a acústica é boa e a temperatura varia de acordo com cada ambiente.

Na sala de recuperação a equipe de enfermagem faz uma entrevista prévia com o paciente e/ou acompanhante, verifica os sinais vitais, punciona acesso venoso periférico, verifica glicemia capilar periférica, realiza tricotomia do local, e checa os exames laboratorial e de imagens. Quando o paciente retorna do exame, são aferidos os sinais vitais, faz-se o curativo, orienta o paciente quanto ao repouso, e ele só é liberado após avaliação do anestesista. O local é bem iluminado, limpo e climatizado, possui seis camas automáticas, suportes para soro, lixeiras, cadeiras plásticas para os acompanhantes, dois 
monitores cardíacos (antigos), carro de urgência, bomba de infusão de soro, aparelho de eletrocardiograma e de coagulação, uma escada tipo hospitalar, prateleiras com materiais descartáveis e rede de gases, porém não existe pia para a higienização das mãos, apenas um dispensador de álcool gel e não existe local para a equipe de enfermagem ficar acomodada.

Segue normas específicas como a Portaria № 453 de 02/06/98 do Ministério da Saúde que estabelece requisitos de proteção radiológica e controle de qualidade para radiologia médica, odontológica e intervencionista; a NR 32, que estabelece as diretrizes para proteção à saúde dos trabalhadores nos serviços de saúde; e a RDC 50 de 2002 da Agência Nacional de Vigilância Sanitária (ANVISA), que dispõe sobre o regulamento técnico para planejamento, programação, elaboração e avaliação de projetos físicos de estabelecimentos assistenciais de saúde.

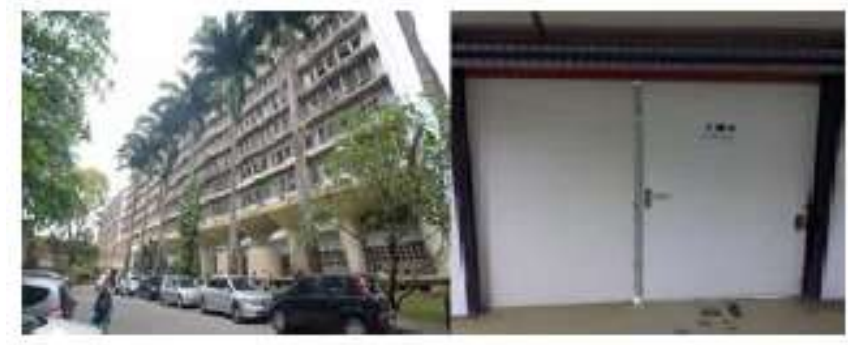

A figura 1 mostra uma vista externa do Hospital e a porta de acesso ao setor de Hemodinâmica. Fonte: arquivo dos pesquisadores

A edificação é de $296 \mathrm{~m}^{2}$ de área construída, piso em placas vinílicas claras, paredes revestidas com chumbo (nas salas de exames), pintura acrílica semi-brilho de cor clara e teto com forro removível branco. Possui 26 (vinte e seis) ambientes: entrada, recepção, posto de enfermagem/farmácia, primeiro corredor, sala de recuperação, sala de exames (desativada), consultório médico, sala administrativa, lavabo (desativado), sala de guarda roupas, sala de chefia de enfermagem, vestiário e WC dos pacientes, sala de exames, segundo corredor, sala de comando/lavabo, sala de força, sala de gravação de exames, sala de estar médico, sala de vestiário e WC para os médicos, copa/vestiário de enfermagem, WC de enfermagem, sala de suporte para aventais de chumbo e expurgo geral.

Após realização das visitas numa perspectiva de uma abordagem macro no setor de Hemodinâmica, observamos que o ambiente é limpo, todavia apresenta uma má conservação, a iluminação é precária, o mobiliário e os equipamentos são antigos, a acústica é boa e a temperatura ambiental varia de acordo com cada ambiente.

\section{Etapa 2: Identificação da Configuração Ambiental}


Nesta etapa são identificadas as condições físico-ambientais do Ambiente e todos os dados são coletados. Adquirimos a planta baixa do setor (desatualizada), vários ambientes foram modificados.

A análise realizada contemplou três ambientes: posto de enfermagem, sala de recuperação e sala de exames. No posto de enfermagem existe um balcão de fórmica (antigo) com gavetas, duas cadeiras giratórias, dois armários e uma pequena sala onde se guarda as medicações e os materiais descartáveis. É neste local onde se faz a admissão dos pacientes pela equipe de enfermagem, orientando-os a trocar de roupa, pesar e medir.

Na sala de exames todas as paredes tem proteção de chumbo, é bem iluminada, limpa e climatizada, tem um angiógrafo (antigo), armários e balcões em formica (antigos), negatoscópio, foco de luz (de teto), suportes de soro, carro de anestesia, monitor cardíaco, bomba de infusão de soro e bomba injetora de contraste, duas cadeiras, escada tipo hospitalar, rede de gases, duas mesas de fórmicas grandes (antigas). A sinalização indicando "equipamento em funcionamento" na entrada da sala não funciona e não tem sonorizador.

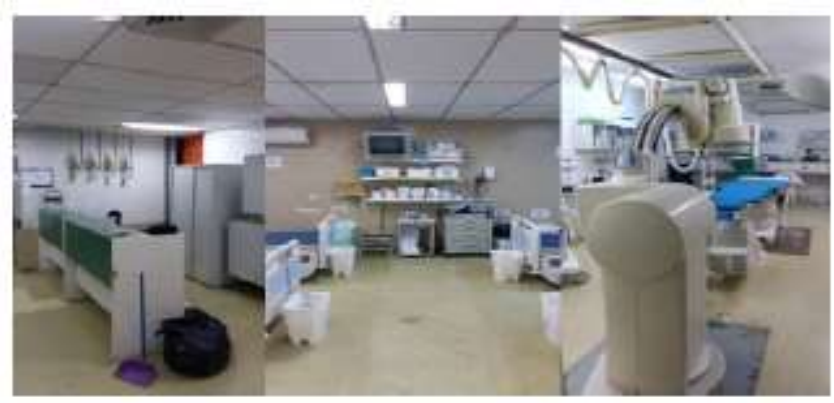

Figura 2. Posto de enfermagem, sala de recuperação e sala de exames

Fonte: Arquivo dos pesquisadores

PLANTA BAIXA DA HEMODINÂMICA

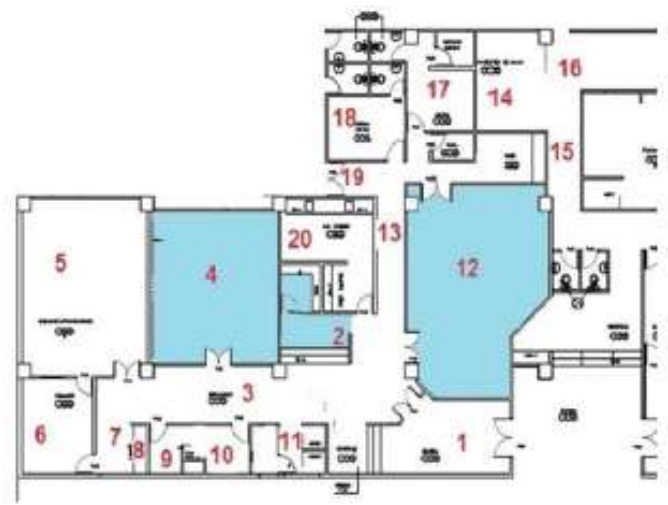

Figura 3. Planta baixa da hemodinâmica 


\section{Entrada/Recepção}

2. Posto de enf./farmácia

3. Primeiro corredor

4. Sala de recuperação

5. Sala de exame desativada

6. Consultório médico

7. Sala do administrativo

8. Lavabo desativado

9. Sala de guardar roupas

10. Sala/chefia enfermagem

11. Vestiário e WC p/pacientes

12. Sala de Exames

13. Segundo corredor

14. Sala de comando/lavabo

15. Sala de força

16. Sala de gravação

17. Estar/vestiário/WC médicos

18. Copa/vestiário/WC de enfermagem

19. Sala de suporte para aventais

20. Expurgo

\section{ACESSIBILIDADE E DESENHO UNIVERSAL}

A Norma Técnica utilizada para o parâmetro de avaliação dos aspectos de acessibilidade foi NBR 9050/2015 e também vimos alguns aspectos no que diz respeito à segurança, observando que o serviço não tem rota de fuga e que os extintores de incêndio estão sem sinalização e com acessos obstruídos. 
O acesso ao setor de Hemodinâmica pode ser por escadas, rampas (observamos uma rampa sem corrimão) e elevadores com sinalização visual e sonora. A acessibilidade é comprometida apenas ao vestiário e WC para os pacientes devido a porta que mede $78,5 \mathrm{~cm}$ de largura, não atendendo a especificação exigida pela legislação NBR 9050/2015 que é de $80 \mathrm{~cm}$ de largura e também não existe barras de apoio nem na vestiária e nem no WC dos mesmos.

\section{AVALIAÇÃO DO CONFORTO LUMÍNICO}

A iluminação artificial é formada por luminárias para lâmpadas fluorescentes de $40 \mathrm{~W}$ e permanecem acesas durante toda a manhã e tarde, a noite é desligada pelo último funcionário que sai. O nível de iluminância foi medido com o aplicativo Lux Meter, para celular, os dados estão descritos no quadro a seguir e os resultados foram comparados com os níveis indicados pela norma NBR 5413/1992. Esta norma embora tenha sido revogada em 2013, para efeitos de avaliação ergonômica continua vigente, amparada pela Nota Técnica 224 de 2014 do Ministério do Trabalho e Emprego.

\begin{tabular}{|l|c|c|c|}
\hline AMBIENTE & PONTO & $\begin{array}{c}\text { MED } \\
\text { (lux) } \\
08: 00 h\end{array}$ & $\begin{array}{c}\text { NBR } \\
\mathbf{5 4 1 3} \\
\text { (lux) }\end{array}$ \\
\hline Posto de Enfermagem & 3 & 140,00 & 150 \\
\hline Sala de Recuperação & 5 & 110,00 & 150 \\
\hline Sala de Exames & 15 & 250,00 & 300 \\
\hline
\end{tabular}

Tabela 1. Quadro com dados da medição do conforto lumínico

Observamos que nos três ambientes escolhidos para o estudo, a iluminação estava não conforme com a norma, provavelmente, devido a várias lâmpadas que se apresentavam queimadas.

\section{AVALIAÇÃO DO CONFORTO ACÚSTICO}

As condições de conforto acústico foram analisadas a partir das medições do ruído interno, a fim de averiguar se os resultados estariam compatíveis com os índices considerados aceitáveis pela NBR 10152 (ABNT 2000). Os pontos analisados foram os mesmos para o conforto lumínico. O nível de ruído foi medido com o aplicativo Sound Meter para celular, os dados estão descritos no quadro a segui. 


\begin{tabular}{|l|c|c|l|}
\hline & PONTO & $\begin{array}{l}\text { MED } \\
\text { (dB) } \\
08: 00 h\end{array}$ & $\begin{array}{l}\text { NBR } \\
\mathbf{1 0 1 5 2} \\
\text { (dB) }\end{array}$ \\
\hline Posto de Enfermagem & 3 & $83 \mathrm{~dB}$ & 35 a 45 \\
\hline Sala de Recuperação & 5 & $95 \mathrm{~dB}$ & 35 a 45 \\
\hline Sala de Exames & 15 & $88 \mathrm{~dB}$ & 35 a 45 \\
\hline
\end{tabular}

Tabela 2. Quadro com dados da medição do conforto acústico

Observamos que nos três ambientes escolhidos para o estudo, a acústica estava também não conforme com a norma, provavelmente, devido ao grande fluxo de pessoas circulando no ambiente e equipamentos em funcionamento.

\section{AVALIAÇÃO DO CONFORTO TÉRMICO}

A NR 17 Sugere variação de $20^{\circ} \mathrm{C}$ a $23^{\circ} \mathrm{C}$. Na sala do administrativo possui um condicionador de ar split de marca yang de 1.800 btu's, na sala de recuperação um split maxiflex de 30.000 btu's, na sala de exames, dois splits um rheem de 8.000 btu's e um springer maxiflex de 30.000 btu's, na sala de força tem dois splint, um Elgin de 3.000 btu's e outro de 1.800 btu's e na sala de gravação um Split yang de 1.800 btu's. O nível de temperatura foi medido com um aparelho TERMO ANEMÔMETRO DIGITAL MDA-II, os dados estão descritos no quadro a seguir.

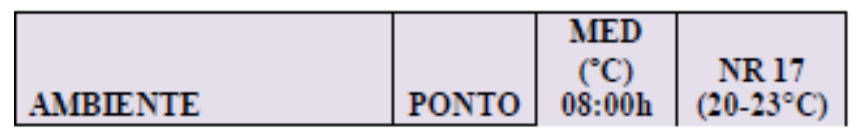

\begin{tabular}{|l|c|c|c|}
\cline { 3 - 4 } Posto de Enfermagem & 3 & $26.0^{\circ} \mathrm{C}$ & $20-23^{\circ} \mathrm{C}$ \\
\hline Sala de Recuperação & 5 & $23,6^{\circ} \mathrm{C}$ & $20-23^{\circ} \mathrm{C}$ \\
\hline Sala de Exames & 15 & $19,5^{\circ} \mathrm{C}$ & $20-23^{\circ} \mathrm{C}$ \\
\hline
\end{tabular}

Tabela 3. Quadro com dados da medição do conforto térmico

Observamos no que diz respeito à temperatura, que os três ambientes estão não conformes em relação com a norma, e que na sala de exames os equipamentos precisam trabalhar em ambiente extremamente frio, evitando danos aos mesmos. 


\subsubsection{AVALIAÇÃO DO AMBIENTE EM USO}

\section{AVALIAÇÃO DO AMBIENTE EM USO NO DESEMPENHO DE SUAS ATIVIDADES:}

Nesta etapa podemos avaliar a eficiência da edificação e seus espaços para o desenvolvimento dos procedimentos realizados na Hemodinâmica.

\section{Fluxograma}

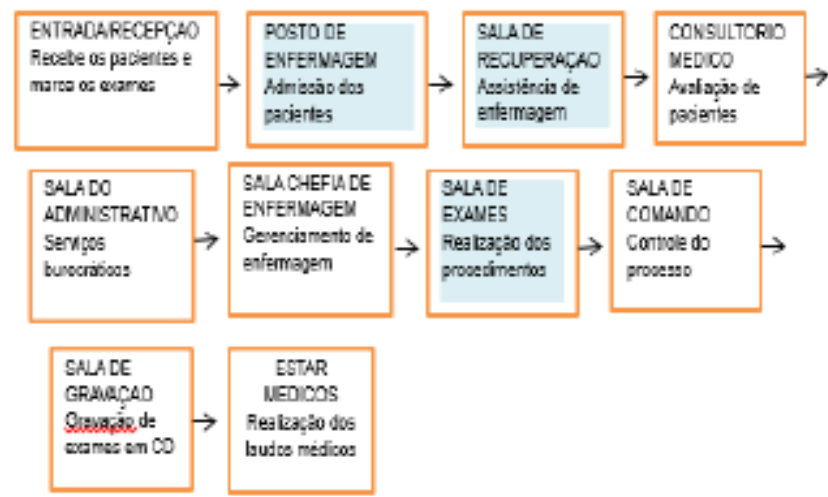

Figura 4. Fluxograma dos postos de trabalho e suas atividades

Na figura acima, esquematizamos os diferentes postos de trabalho que compõem o setor de Hemodinâmica, descrevendo as funções exercidas para o cumprimento dos procedimentos realizados.

POSTO DE ENFERMAGEM: Local onde recebemos os pacientes e acompanhantes com as fichas para breve entrevista e troca de roupas, disponibilizado um balcão grande em fórmica com gavetas, três cadeiras pretas giratórias e reguláveis, material de escritório, um telefone de ramal e dois armários grandes (antigos) de fórmica.

SALA DE RECUPERAÇÃO: Local onde se faz o pré e pós exames, no pré: os pacientes ficam deitados de roupa trocada, já foram pesados e medidos, a enfermagem verifica os sinais vitais, punciona um acesso venoso periférico, realiza tricotomia e faz a glicemia capilar periférica, os mesmo permanecem em dieta zero antes do exame e seus acompanhantes sentados em cadeiras ao lado da cama. No pós: os pacientes retornam para o mesmo leito, a enfermeira realiza o curativo, libera dieta e ficam em repouso de acordo com o procedimento realizado e só são liberados após avaliação do anestesista. A mobília é composta de seis camas automáticas, seis cadeiras plásticas para acompanhantes, seis suportes de soro, duas escadas tipo hospitalar (antigas) pintadas, dois biombos, três prateleiras com os monitores cardíacos (antigos), uma rede de gases em cada leito com ar comprimido, oxigênio e vácuo, um aparelho de eletrocardiógrafo, um carrinho de emergência com 
desfibrilador, medicações e materiais descartáveis, um compressor mecânico, uma TV (antiga), duas prateleiras com soros e materiais descartáveis, um condicionador de ar e dez lixeiras sem tampa para (lixo contaminado, lixo comum, frascos de soros vazios e restos alimentares) e uma caixa para descarte de materiais pérfuro-cortantes. E quando superlotado, duas macas ficam no corredor dentro da sala de recuperação dificultando a acessibilidade. Observamos a falta de uma pia para higienização das mãos, em desacordo com a RDC 50.

SALA DE EXAMES: Local para realização dos exames. Todas as paredes com proteção de chumbo como preconiza a legislação, a iluminação aparentemente boa, mesmo faltando algumas lâmpadas, ambiente limpo e climatizado por dois condicionadores de ar, o piso precisando ser trocado, com um angiógrafo (antigo), armários e balcões em fórmica (antigos), negatoscópio, foco de teto, suporte de soros, carro de anestesia, monitor cardíaco, bomba de infusão de soro, uma bomba injetora de contraste, duas cadeiras, escada tipo hospitalar, rede de gases, duas mesas de formicas grandes (antigas), dois quadros brancos. A sinalização indicando equipamento em funcionamento na entrada da sala não funciona e não tem sonorizador dentro da sala para comunicação com a sala de comando na parte externa.

\section{AVALIAÇÃO ANTROPOMÉTRICA}

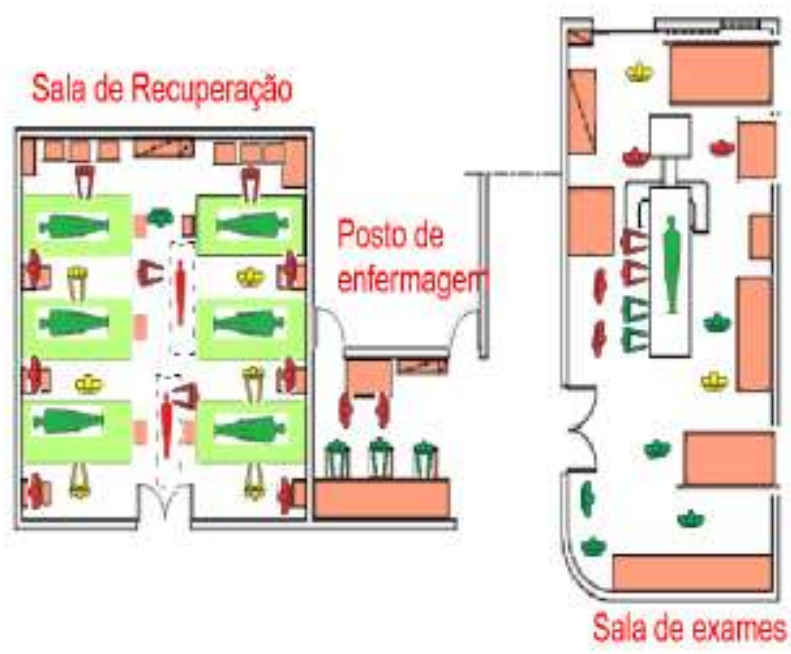

Figura 5. Avaliação Antropométrica

O layout da sala de recuperação nos permite identificar que a circulação de pessoas torna se dificultada pelo elevado número de usuários. A sala, nos mostra que pela sua finalidade, deveria estar melhor disposta quanto ao mobiliário, bem como maior restrição de usuários circulantes. Os pontos críticos observados são o corredor e a lateral dos leitos dos pacientes. Um dos problemas de maior 
importância ergonômica deve se à falta de espaço para colocação de macas, tendo em vista que muitos procedimentos acontecem num curto período de tempo, causando desconforto aos próximos pacientes que estão à espera do seu procedimento. Outro ponto de não conformidade foi o posto de enfermagem, o qual além de mal estruturado, possui pouco espaço e falta de cadeiras para os profissionais e a existência de armários na parede, dificultando a circulação dos usuários no posto de enfermagem. No tocante à sala de exames, observa se amplitude do espaço, bem como variação de possibilidades de acomodação do mobiliário. Os espaços entre os profissionais podem ser melhorados, diminuindo o número dos mesmos no momento de cada procedimento.

\subsection{ETAPA 4: PERCEPÇÃO AMBIENTAL DO USUÁRIO}

De acordo com Villarouco (2008), um ponto importante da avaliação do ambiente construído é a percepção do usuário, por ser o elemento que mais sofre com todas as sensações que o ambiente pode gerar.

Assim, foi aplicada a Constelação de Atributos, ferramenta idealizada por Moles em 1968 e que permite a compreensão da consciência psicológica do usuário frente ao espaço que ocupa. Esta representação gráfica é composta por um núcleo que representa o objeto de estudo e por "estrelas" que representam os atributos especiais. A distância entre o atributo e o núcleo, chamada de distância psicológica, determina o grau de importância de cada atributo, além de auxiliar no conhecimento da percepção do usuário em relação ao ambiente (VASCONCELOS; VILLAROUCO; SOARES, 2009).

Para a construção do gráfico da Constelação de Atributos foram realizadas duas perguntas, propiciando a análise de duas esferas do ambiente construído: uma para a conceituação do Serviço de Hemodinâmica Imaginário (Ideal), com associação de ideias voltadas para as características espontâneas, e outra que define o serviço de Hemodinâmica Real, com associação de ideias a partir de características induzidas.

Segundo Vasconcelos; Villarouco; Soares (2010), ao analisarmos o grau de aproximação e/ou afastamento das variáveis nas constelações dos atributos, percebe-se que aqueles elementos mais próximos do centro, onde está representado o objeto de estudo, exercem uma relação mais direta para explicar o fenômeno de percepção e adaptação do espaço. Os que estão mais afastados demonstram o fenômeno observado com menor propriedade. 


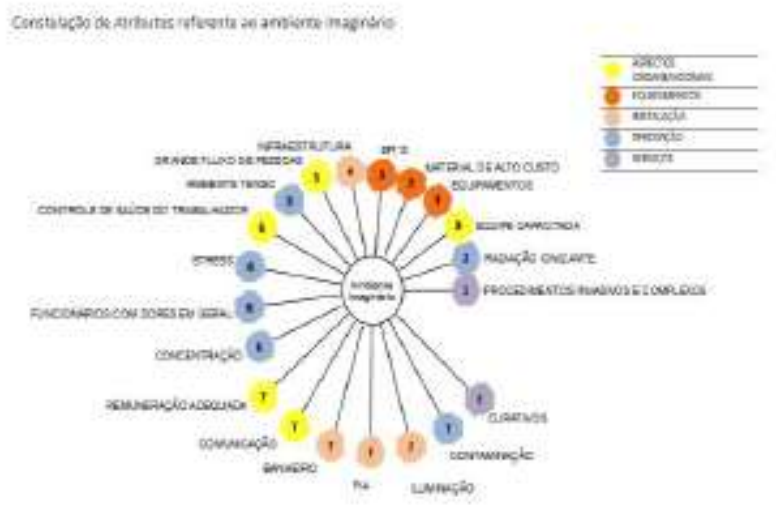

Figura 6. Constelação de atributos Hemodinâmica IDEAL

A constelação de atributos IDEAL é baseada na pergunta que pede respostas relacionadas à expectativa de uso de um ambiente imaginário, identificando aspectos que o usuário deseja, ou seja, um ambiente considerado ideal e que o satisfaça em diversos sentidos. Já a constelação de atributos REAL é baseada na pergunta que requer respostas de cunho objetivo, onde o entrevistado irá falar sobre o ambiente que está frequentando, opinando através de uma visão real.

Importante salientar na avaliação da constelação de atributos para a Hemodinâmica Ideal que os profissionais de enfermagem demonstraram a percepção de um ambiente bem estruturado e organizado, que reflete em um melhor atendimento ao usuário no que diz respeito à realização dos procedimentos invasivos e complexos, assim como, a questão da segurança na proteção contra a radiação ionizante. Estes fatores de maior expressão apontam para uma grande importância dada aos atributos relativos aos aspectos organizacionais, os quais estão diretamente ligados à qualidade do trabalho prestado e satisfação dos profissionais.

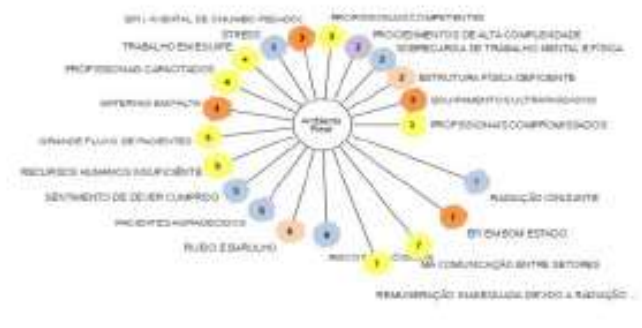

Figura 7. Constelação de atributos Hemodinâmica REAL 
$\mathrm{Na}$ avaliação do mapa da constelação de atributos para o ambiente Real, observa-se que os profissionais de enfermagem da hemodinâmica são compromissados, percebem uma sobrecarga de trabalho mental e física, realizam procedimentos de alta complexidade, mesmo com uma estrutura física deficiente, o que deveria contribuir negativamente para a realização de suas atividades. Esses fatores são de relevante importância não apenas para avaliação da satisfação dos usuários, bem como das instalações físicas. Em relação aos fatores organizacionais, estes aparecem em grande número de citações, principalmente quanto à comunicação entre setores. Fatores como estes deverão ser repassados à direção desta unidade no sentido de otimizar o trabalho realizado e melhorar a satisfação dos usuários que fazem parte desta unidade.

Apesar de se ter por finalidade na Constelação de Atributos, obter a percepção dos usuários quanto ao ambiente, ao espaço físico, o que se percebe é que, quando o trabalho e seus condicionantes exercem uma grande influência e preocupação aos trabalhadores, estes não conseguem se ater ao objeto questionado na aplicação da ferramenta. Isto está aqui demonstrado, quando grandes partes das respostas não se referem ao ambiente físico investigado.

\subsection{ETAPA 5: DIAGNÓSTICO ERGONÔMICO DO AMBIENTE E RECOMENDAÇÕES}

De um modo geral, com intuito de eliminar ou diminuir os problemas identificados, e portanto melhorar o desenvolvimento das atividades no trabalho e a satisfação dos usuários, construiu-se o quadro abaixo com os respectivos diagnósticos e as recomendações que deverão ser realizadas a curto, médio e longo prazo, a partir dos problemas identificados pela percepção dos pesquisadores e usuários, além dos dados levantados pelas entrevistas, medições, observações e questionários. 


\begin{tabular}{|l|l|}
\hline DIAGNOSTICOS & RECOMENDAÇÓES \\
\hline $\begin{array}{l}\text { Sala de Exames sem áudio } \\
\text { e com a Lâmpada de } \\
\text { sinalização visual } \\
\text { "queimada". }\end{array}$ & $\begin{array}{l}\text { Instalar sonorizador dentro } \\
\text { da sala de exames e trocar a } \\
\text { lâmpada de sinalização } \\
\text { visual. }\end{array}$ \\
\hline $\begin{array}{l}\text { Extintores sem sinalização } \\
\text { e com acesso obstruido. }\end{array}$ & $\begin{array}{l}\text { Sinalizar adequadamente os } \\
\text { extintores e liberar o acesso } \\
\text { aos mesmos. }\end{array}$ \\
\hline $\begin{array}{l}\text { Copa e vestiário juntos, e } \\
\text { WC único para ambos os } \\
\text { gêneros de profissionais. }\end{array}$ & $\begin{array}{l}\text { Separar a copa do vestiário e } \\
\text { do WC dos funcionários, e } \\
\text { providenciar WC separados. }\end{array}$ \\
\hline $\begin{array}{l}\text { Sala de recuperação sem } \\
\text { pia para higienização das } \\
\text { mãos. }\end{array}$ & $\begin{array}{l}\text { Instalação de uma pia para } \\
\text { higienização das mãos na } \\
\text { sala de recuperação. }\end{array}$ \\
\hline $\begin{array}{l}\text { WC dos pacientes sem } \\
\text { barra de segurança. }\end{array}$ & $\begin{array}{l}\text { Instalação de barra de } \\
\text { segurança no WC dos } \\
\text { pacientes. }\end{array}$ \\
\hline $\begin{array}{l}\text { Vestiário dos pacientes } \\
\text { com porta medindo } 78,5 \\
\text { cm. }\end{array}$ & $\begin{array}{l}\text { Ampliar a porta do vestiário } \\
\text { dos pacientes. }\end{array}$ \\
\hline $\begin{array}{l}\text { Grande fluxo de pessoas na } \\
\text { sala de recuperação. }\end{array}$ & $\begin{array}{l}\text { Minimizar a entrada de } \\
\text { acompanhantes na sala de } \\
\text { recuperação. }\end{array}$ \\
\hline $\begin{array}{l}\text { Leitos da sala de } \\
\text { recuperação sem } \\
\text { divisórias. }\end{array}$ & $\begin{array}{l}\text { Instalar divisórias nos leitos } \\
\text { da sala de recuperação. }\end{array}$ \\
\hline $\begin{array}{l}\text { Mobiliários e } \\
\text { equipamentos antigos e } \\
\text { ultrapassados. }\end{array}$ & $\begin{array}{l}\text { Aquisição de mobiliários e } \\
\text { equipamentos novos e } \\
\text { adequados. }\end{array}$ \\
\hline $\begin{array}{l}\text { Armários de parede } \\
\text { prejudicando o fluxo dos } \\
\text { profissionais no posto de } \\
\text { enfermagem. }\end{array}$ & $\begin{array}{l}\text { Retirar os armários de parede } \\
\text { do posto de enfermagem. }\end{array}$ \\
\hline RH insuficiente. & Redimensionamento de RH. \\
\hline $\begin{array}{l}\text { Falha na comunicação } \\
\text { entre setores. }\end{array}$ & $\begin{array}{l}\text { Criar protocolos de } \\
\text { comunicação entre setores. }\end{array}$ \\
\hline $\begin{array}{l}\text { Aventais de chumbo muito } \\
\text { pesado. }\end{array}$ & $\begin{array}{l}\text { Aquisição de aventais de } \\
\text { chumbo mais leves. }\end{array}$ \\
\hline
\end{tabular}

Tabela 4. Quadro com diagnósticos e recomendações

Foi percebido, através da análise do ambiente, que a Hemodinâmica atende às necessidades a que se propõe. Por sua dimensão teria um potencial para uma maior produtividade se fossem feitos os ajustes necessários. A sala de procedimentos foi considerada bem estruturada fisicamente e respeita quase sempre ao preconizado para as variáveis ambientais e de conforto, necessitando apenas de modernização e revisão de mobiliários existentes bem como a aquisição de equipamentos novos. Em relação ao conforto do ambiente, percebe-se que, pelo alto número de usuários, elevam-se os ruídos e a temperatura. O layout apresenta alguns pontos críticos, por se tratar de um hospital escola, a circulação de pessoas é maior que o normal, necessitando de mais espaços ou redução do número de pessoas que transitam durante os procedimentos. Os usuários relatam alguns problemas relacionados à iluminação. Para esta variável é importante destacar que a iluminação da sala de procedimentos 
obedece aos parâmetros. A alta temperatura foi destacada por alguns dos entrevistados, que se dá também pelo número elevado de pessoas circulando. Os três postos de trabalho avaliados foram identificados pela equipe como razoáveis. Os materiais utilizados nos acabamentos destas três unidades atendem às normas específicas, permitindo boa limpeza e evitando maiores riscos de infecção. Em relação a sala de recuperação, necessita de melhor adequação, tais como minimizar a presença de acompanhantes e colocação de pia para higienização das mãos. O posto de enfermagem apresenta dificuldade de circulação devido aos armários afixados na parede, que poderiam ser retirados, facilitando a circulação dos usuários. A sala de procedimentos, por ter um aumento do número de profissionais de acordo com o tipo de exame e também de acordo com as variáveis antropométricas do profissionais, não apresenta muitas possibilidades de mudanças.

\section{CONCLUSÃO}

Como parte da atividade da Disciplina de Ergonomia do Ambiente Construído, dentro do programa de Mestrado Profissional de Ergonomia da UFPE, essa atividade veio com o incentivo de inserir os mestrandos em um cenário de avaliação prática no campo da metodologia de análise ergonômica.

Esta pesquisa possibilitou avaliar o ambiente do serviço de Hemodinâmica através da MEAC, e após o estudo verificou-se a necessidade de algumas intervenções, foi proposto recomendações que deverão ser realizadas a curto, médio e em longo prazo.

Os resultados comprovam que a Ergonomia pode contribuir de forma positiva para a melhoria da qualidade de vida dos profissionais de enfermagem e da assistência prestada aos pacientes usuários do ambiente em estudo. 


\section{REFERÊNCIAS}

ASSOCIAÇÃO BRASILEIRA DE NORMAS TÉCNICAS. NBR 10152: níveis de ruído para conforto acústico. Rio de Janeiro, 2000.

ASSOCIAÇÃO BRASILEIRA DE NORMAS TÉCNICAS. NBR 9050 -Acessibilidade a edificações, mobiliário espaços e equipamento urbanos. Rio de Janeiro, 2015.

ASSOCIAÇÃO BRASILEIRA DE NORMAS TÉCNICAS. NBR 5413: iluminância de interiores. Rio de Janeiro, 1992. 13 p.BRASIL. Ministério do Trabalho e Emprego. NR 17 -Ergonomia. Brasília: 2007.

GUIMARÃES, Lia Buarque de Macedo. Introdução à ergonomia. In: Guimarães, Lia Buarque de Macedo. Ergonomia de Processo, volume 1. Porto Alegre, FEENG/UFRGS. 2004.

MOLES, A. Sociodinâmica de La cultura. Barcelona: Editora Gustavo Gili, 1968.

MONT`ALVÃO, C.; VILLAROUCO, V. Um Novo Olhar para o Projeto: a ergonomia no ambiente construído -Teresópolis: 2AB, 2011.

VASCONCELOS, C.F.; VILLAROUCO, V.; SOARES, M. M. Avaliação ergonômica do ambiente construído: estudo de caso de uma biblioteca universitária. Ação ergonômica, v.4.p. 5-25, 2009.

VILLAROUCO, V.; ANDRETO, L. F. M. Avaliando desempenho de espaços de trabalho sob o enfoque da ergonomia do ambiente construído. Produção, v. 18, n. 3, p. 523-539, 2008.

VILLAROUCO, V. FALCÃO E VASCONCELOS; SOARES M.M. Contribuição da psicologia ambiental na análise ergonômica do ambiente construído. Ação Ergonômica. V. 5, n. 3, dez/2010. 


\section{d.)}

\section{Capítulo 6}

\section{ANÁLISE DA GESTÃO DE ESTOQUES EM UMA EMPRESA GRÁFICA DIGITAL}

Thaiara Oliveira da Silva

Cintia Camila de Mello Martinez

Paula Donaduzzi Rigo

Angélica Alebrant Mendes
Universidade Federal de Santa Maria

Universidade Federal de Santa Maria

Universidade Federal de Santa Maria

Universidade Federal do $A B C$ 
Resumo: Devido a necessidade de as empresas organizarem seus estoques, com foco em otimização de área destinada e dos custos de compra e manutenção, o trabalho tem por objetivo calcular o lote econômico de cada produto selecionado como importante em uma empresa do ramo de gráfica digital localizada em Santa Maria - RS. Metodologicamente, a importância desses produtos foi dada pelo método da curva $A B C$ e após foi calculado o lote econômico para as classes $A$ e $B$, para que os custos relacionados aos estoques desses produtos sejam reduzidos. Desse modo, foi analisada a produção dos carros chefes da empresa: impressão e encadernação. Ao término deste estudo foi constado que o proprietário realiza as compras bem próximas ao que foi apontado pelo cálculo do lote econômico de compra, tendo apenas um produto com diferença significativa de seis semanas.

Palavras-chave: Gráfica digital. Curva ABC. Lote econômico de compra. 


\section{INTRODUÇÃO}

Segundo Borges, Campos e Borges (2010) para se ter uma maior vantagem competitiva as empresas buscam a otimização de todos os processos dentro da organização, o que demanda um gerenciamento da qualidade em todas as etapas do processo produtivo. Ainda segundo o autor, um gerenciamento de estoque adequado e bem sucedido faz com que haja uma redução de custos e garante estoques nos níveis de segurança ideais para atender a demanda.

Dessa forma, as empresas têm a necessidade de um gerenciamento de estoques efetivo que faça com que elas não armazenem tanto estoque, que acarretará em custos elevados, e que ao mesmo tempo possuam as matérias-primas necessárias para atender aos pedidos de seus clientes. Por esse motivo as empresas precisam buscar formas de estudar e gerenciar os seus estoques e para isso, no entender de Santoro e Freire (2008), há muito tempo tem-se utilizado modelos matemáticos para o auxílio da manutenção dos estoques, sendo que, em 1915, foi publicado o primeiro estudo sobre lote econômico.

À vista disso, o objetivo geral do trabalho é calcular o lote econômico de compra para uma empresa do ramo de gráfica digital da cidade de Santa Maria - RS. E tem como objetivo específico realizar o método da curva $A B C$, que segundo Pereira (2016) identifica os produtos que devem ter atenção dentro da empresa através da sua importância relativa. Inicialmente identificam-se os principais produtos que apresentam os maiores custos associados à demanda e ao valor de compra para a empresa e por fim realiza-se o cálculo do lote econômico de compra.

A partir desse cenário, o problema do estudo se caracteriza por a empresa não apresentar um controle de seus estoques, o que concentra toda as decisões sobre compra nas mãos do proprietário, causando fragilidades na rotina da empresa nos possíveis dias em que este responsável não se encontra na empresa, deixando os colaboradores sem o conhecimento necessário sobre qual o momento certo de colocação do pedido e em que quantidade comprar. Nesse impasse esses colaboradores podem vir a comprar quantidades inadequadas e aumentar os custos associados ao estoque. Além disso, não é comprovado que as quantidades e o período de compra utilizado hoje pela empresa é aquele que apresenta os menores custos.

Este trabalho se apresenta dividido em cinco seções. Logo após a introdução encontra-se a seção dois que trata do referencial teórico que conduziu esse estudo. Sequencialmente, na terceira seção é apresentada a metodologia utilizada. Enquanto que na quarta seção, constam os resultados e 
discussão acerca dos cálculos da Curva $A B C$ e do lote econômico de compra. E a quinta e última seção, remete as considerações finais e as sugestões de futoros estudos.

\section{REFERENCIAL TEÓRICO}

\subsection{EMPRESA GRÁFICA DIGITAL}

O setor gráfico apresenta grande importância no cenário econômico brasileiro, pois além de ser muito diversificada para atender a vários setores da economia ela também, na última análise, oferecia cerca de duzentos mil empregos diretos (SMA, 2003). As empresas gráficas digitais somam um total de 20.295 empresas, sendo que $88 \%$ são consideradas micro e pequenas empresas, e o faturamento do ano de 2008 deste setor foi de R\$23,1 bilhões (SEBRAE, 2009).

A mesma pesquisa feita pelo SEBRAE (2009) aponta que os tipos de produtos mais produzidos pelas gráficas são as impressões $(67,2 \%)$ e quanto às classificações das empresas, essas seguem uma proporção de:

a) Gráfica comercial com $98,2 \%$;

b) Gráfica religiosa com 0,7\%;

c) Gráfica sindical com 0,6\%; e

d) Gráfica pública com $0,5 \%$.

Diante disso, o alto volume de produção destas empresas se dá através do uso de insumos (folhas e tonners de tintas) que necessitam de análises quanto à disponibilidade, custos de manutenção e custos de colocação de pedidos.

\subsection{GESTÃO DE ESTOQUES}

A gestão de estoques é uma função essencial para a logística integrada, e tem como objetivo garantir o nível de serviço desejado pela empresa utilizando o mínimo de recursos, ou seja, com o mínimo custo logístico total (GARCIA et al., 2006). Em vista disso, a gestão de estoques engloba o planejamento do estoque, o controle e sua retroalimentação em relação ao planejamento. Dessa forma, a gestão de estoques inclui a função de compras, de acompanhamento, gestão de armazenagem, Planejamento e Controle da Produção (PCP) e gestão da distribuição física dos insumos (CHING, 2010).

Diante desse cenário, é necessário identificar metodologias para apoiar a gestão de estoque. Uma delas é a Curva ABC, que para Paoleschi (2014) é muito utilizada na administração de estoques, 
principalmente como um parâmetro para informar a necessidade de adquirir matérias-primas muito importantes para o estoque da empresa analisada. A curva $A B C$ divide os materiais em três grandes grupos levando em consideração os seus custos e quantidades, sendo que a classe A comporta os itens de valor de demanda alta, classe B valor de demanda médio e classe C valor de demanda baixo (SILVA, 2014).

Por conseguinte, tem-se o Modelo Econômico de Compra (LEC). Na concepção de Rogers, Ribeiro e Rogers (2004) o LEC é utilizado para determinar a quantidade ideal de recursos que se deve aplicar nos itens estocados, que nas palavras de Ferreira e Guerreiro (2013) é a quantidade de itens comprados que minimizam o custo total anual em estoque. O Lote econômico de compra pode ser calculado através da Fórmula 1 apontada pelo autor Wanke (2011).

$$
Q^{*}=\sqrt{\frac{2 * D * C T R}{i * C a q}}
$$

Onde:

$Q^{*}$ : tamanho de lote;

D: consumo de unidades ao ano;

CTR: custo de ressuprimento ou custo de colocação de pedido [R\$];

Caq: custo unitário de aquisição [R\$]; e

i: taxa de manutenção do estoque.

E para calcular o número de pedidos, Rogers, Ribeiro e Rogers (2004) apontam a Fórmula 2.

$$
N=\frac{D}{Q^{*}}
$$

Onde:

$\mathrm{N}$ : número de pedidos a se fazer ao ano;

D: é a demanda anual; e

Q*: é o tamanho de lote ideal. 
Através da Fórmula 1 é obtido a quantidade ideal de compra, sendo que cada item estudado possui um lote economico de compra associado ao seu custo de ressuprimento e seu custo de aquisição. $\mathrm{E}$ a Fórmula 2 aponta o número de pedidos do período de um ano, levando em consideração o resultado da Fórmula 1 e a demanda anual do item.

\section{METODOLOGIA}

A presente pesquisa foi aplicada em uma empresa do ramo gráfica digital que atua em Santa Maria a mais de 20 anos. A empresa iniciou com o ramo de encadernações de trabalhos acadêmicos e de livros fiscais e ao longo do tempo agregou o ramo de presentes e papelaria. Atualmente, a empresa optou por focar em seu carro chefe, que é o serviço de impressão seguido da encadernação e para complementar seus serviços, ela também oferece a formatação de trabalhos científicos aos seus clientes.

O processo escolhido para análise é o de impressão e encadernação, pois este além de ser o carro chefe da empresa, representa a totalidade dos insumos adquiridos pela mesma. O processo inicia com a impressão do trabalho requerido, após isso ocorre a furação lateral de todas as folhas juntas, na sequencia, as folhas são costuradas, é colocada a contra capa e no final ocorre o refile, processo dedicado a retirada dos excessos em torno do trabalho e considerado como a etapa final (Figura 1).

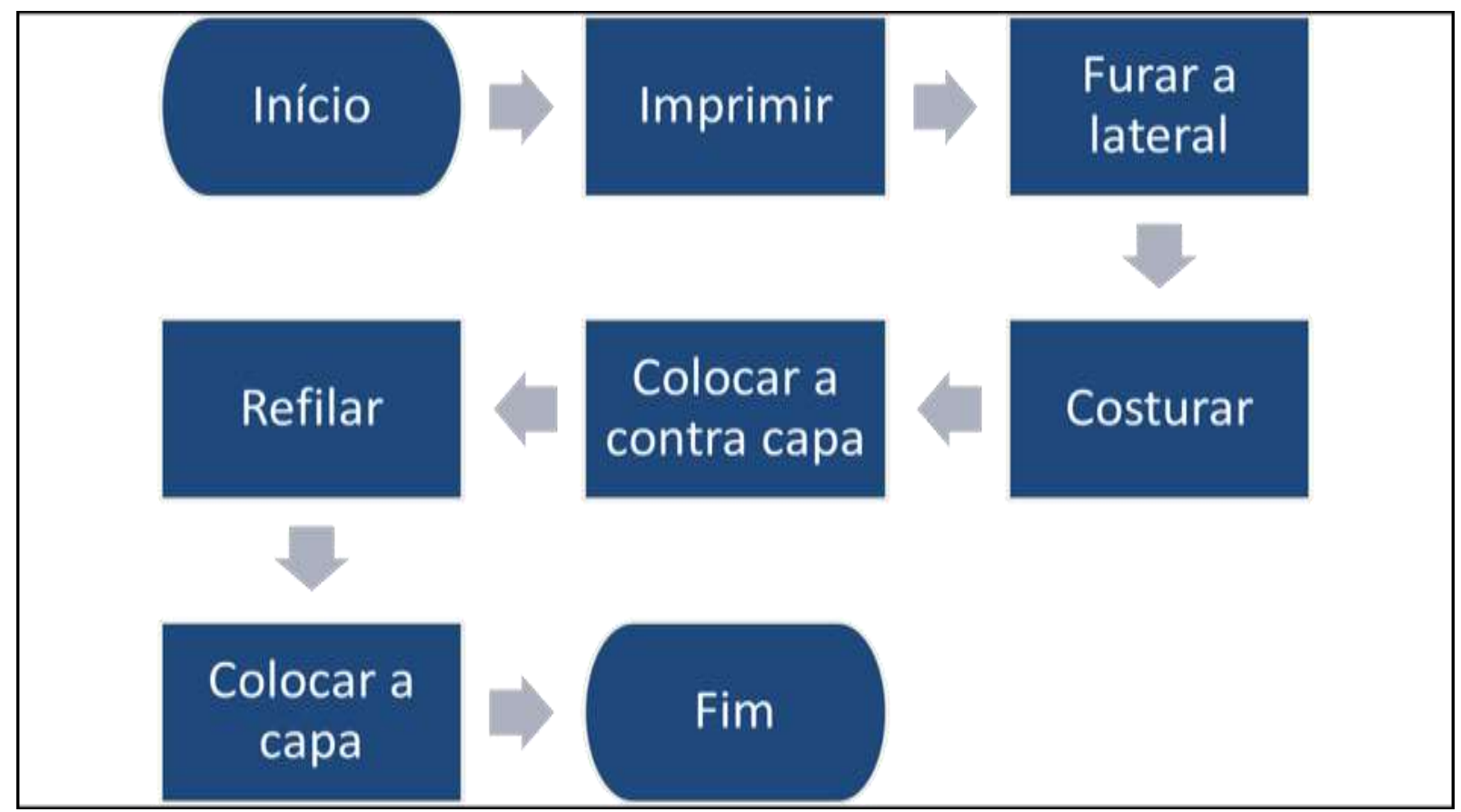

Figura 1 - Fluxograma do processo de impressão e encadernação 
Para a realização do processo descrito na Figura 1, tem-se como uma preocupação do proprietário a melhor gestão do estoque gerado pelos insumos. Em vista disso, objetiva-se através da curva $A B C$ selecionar quais os produtos mais importantes para a empresa, quanto à quantidade e/ou valor agregado e que representam o maior impacto caso não estejam disponíveis no estoque. Além disso, identificar através do cálculo do lote econômico qual o tamanho ideal do lote dos produtos mais importantes e em que momento o pedido deve ser realizado.

As etapas que foram utilizadas para auxiliar no sequenciamento lógico do estudo estão descritas a seguir:

Etapa 1 - Revisão bibliográfica. Compreender por meio da pesquisa o contexto do trabalho, no que se refere à realidade das empresas do setor gráfico, proporção no mercado, representatividade e descrição do processo. E ainda, a importância da gestão do estoque através da curva $A B C$ atrelada à analise do lote econômico.

Etapa 2 - Levantamento dos dados de compra da empresa. Através da entrevista com o proprietário da empresa foram obtidos os dados de compra de insumos da mesma, elencando dados como tipo de produto, quantidade mensal de compra, valor individual e total, porcentagem total e acumulada.

Etapa 3 - Análise dos dados. Os dados foram preenchidos em planilha eletrônica (Microsoft Excel) e analisados pelo grupo de estudo. O intuito dessa etapa é discutir sobre qual a melhor forma de proceder com a análise, no que se refere a classificação correta dos insumos na curva $A B C$ e a sugestão de melhorias significativas para a empresa, trazendo retorno positivo para o processo analisado.

Etapa 4 - Realização da curva $A B C$ para os produtos da empresa. Estabeleceram-se quais os itens mais importantes para a empresa e realizou-se o cálculo de lote econômico para os mesmos. Tornando viável um controle mais apurado dos principais produtos em estoque, capaz de reduzir os custos e manter o um nível de serviço adequado.

Etapa 5 - Sugestão de melhoria. Através da análise dos métodos aplicados, apresentar à empresa uma sugestão de compra com o tamanho de lote ideal para os itens críticos selecionados e o número certo de pedidos realizados ao ano, capaz de diminuir o custo associado ao estoque. 


\section{RESULTADOS}

Através da análise organizacional da cadeia de suprimentos da empresa, apresentada na Figura 2, foi possível estruturar o relacionamento de fornecedores e clientes para com a empresa e cada um deles em dois níveis da cadeia.

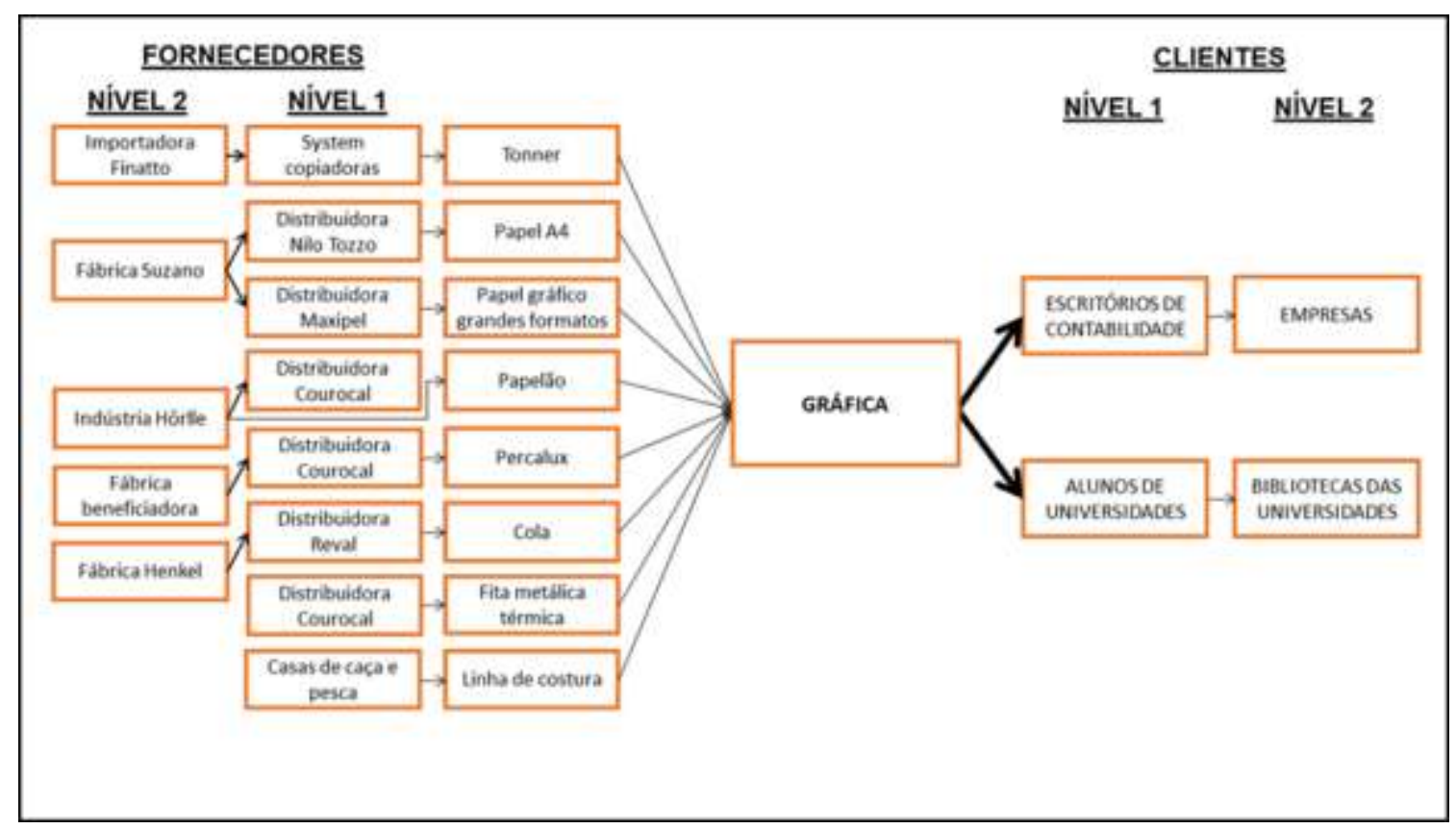

Figura 2 - Cadeia de suprimentos da Gráfica

A análise dos fornecedores resultou em uma lista de insumos necessários para a rotina da empresa (Figura 2). Essa lista é composta por oito itens que serão utilizados para o processo de impressão e encadernação. A partir da lista, foram coletados os custos unitários de aquisição de cada item e a quantidade anual consumida historicamente pela empresa, estas informações estão demonstradas na Tabela 1. A coluna "Total" é dada pela multiplicação entre a quantidade de itens pedidos anualmente e valor individual de cada um deles, através dessa coluna foi elaborado o Gráfico de Pareto.

\begin{tabular}{lccccc}
\hline Produto & Qtde & Valor do item & Total & Porcentagem & Classificação \\
\hline Tonner Cores & 36 & $\mathrm{R} \$ 570,00$ & $\mathrm{R} \$ 20.520,00$ & $30,18 \%$ & \\
Tonner Preto & 72 & $\mathrm{R} \$ 230,00$ & $\mathrm{R} \$ 16.560,00$ & $24,35 \%$ & $\mathrm{~A}$ \\
\hline Papel A4 pct. com 500fls & 540 & $\mathrm{R} \$ 17,40$ & $\mathrm{R} \$ 9.396,00$ & $13,82 \%$ & \\
Papel gráfico grandes formatos & 72 & $\mathrm{R} \$ 125,00$ & $\mathrm{R} \$ 9.000,00$ & $13,24 \%$ & $\mathrm{~B}$ \\
Percalux & 32,4 & $\mathrm{R} \$ 247,50$ & $\mathrm{R} \$ 8.019,00$ & $11,79 \%$ & \\
\hline Cola (litros) & 144 & $\mathrm{R} \$ 15,60$ & $\mathrm{R} \$ 2.246,40$ & $3,30 \%$ & \\
Papelão 1,00x0,80m & 600 & $\mathrm{R} \$ 2,75$ & $\mathrm{R} \$ 1.650,00$ & $2,43 \%$ & $\mathrm{C}$ \\
Fita metálica térmica & 6 & $\mathrm{R} \$ 92,00$ & $\mathrm{R} \$ 552,00$ & $0,81 \%$ & \\
Linha de costura & 3,6 & $\mathrm{R} \$ 15,40$ & $\mathrm{R} \$ 55,44$ & $0,08 \%$ & \\
\hline
\end{tabular}




\section{Tabela 1 - Tabela da curva ABC \\ Fonte: Elaborado pelos autores}

Ressalta-se ainda que a periodicidade de compra utilizada atualmente pela empresa é mensal, tendo como número de pedidos realizados ao ano (N) o valor igual a 12. Sendo assim, todos os insumos da empresa são pedidos na mesma data, sem se analisarem questões como o espaço que o item ocupa no estoque, o custo de manutenção do mesmo e ainda os custos associados diretamente com a aquisição do item, como o custo de colocação do pedido e o valor do item em si.

A representatividade, em porcentagem, para cada um dos produtos pertencentes ao processo de impressão e encadernação, assim como a classificação definida para cada um deles, é observado na Tabela 1. A classificação em A, B e C foi obtida através da análise dos dados de quantidade de compra e preço unitário dos insumos utilizados para o processo selecionado. Os dados também foram representados no gráfico de Pareto (Figura 3) para melhorar a compreensão no que se refere representatividade de cada item isolado.

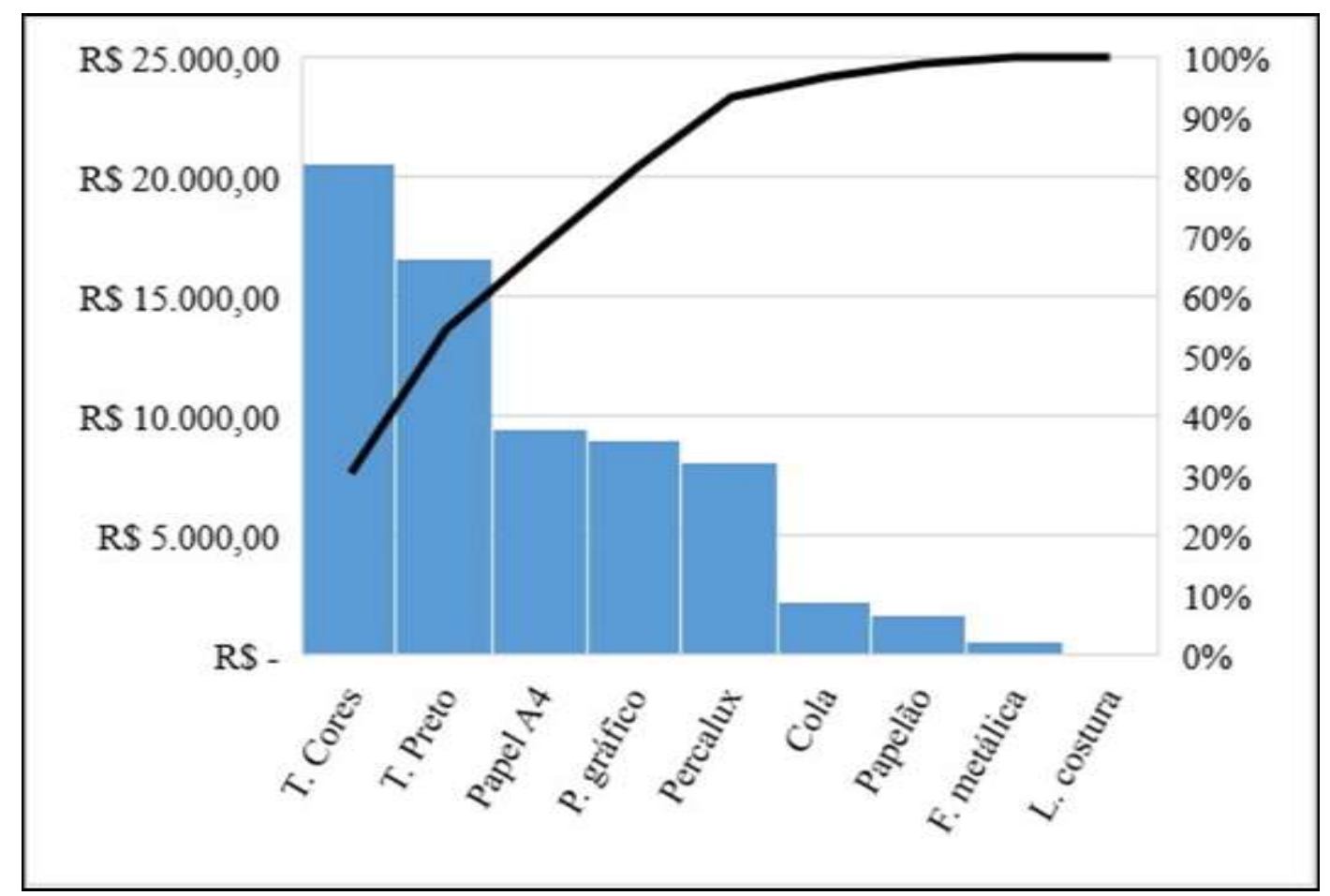

Figura 3-Gráfico de Pareto da curva $A B C$

Após a análise da Tabela 1 juntamente com a Figura 3, nota-se que os dois primeiros itens representam $54,5 \%$ do total de compras da empresa e são classificados como os itens A. Na sequência, os três próximos itens representam $38,8 \%$ do total de compras e foram classificados como $B$, os quatro itens restantes representam $6,62 \%$ e classificam-se como $C$. 
Observa-se que os itens A e B, quando analisados juntos, são responsáveis por 93,38\% do custo total de estoque, logo, é possível caracteriza-los como sendo os itens críticos ou ainda os mais importantes para serem analisados. Em vista disso, o lote econômico de compra foi calculado para esses cinco itens, participantes do segmento $A$ e $B$, conforme a tabela 2.

\begin{tabular}{lcccccc}
\hline \multicolumn{1}{c}{ Produtos } & D & CTR & i & Caq & Q* & N \\
\hline Toner colorido & 36 & $\mathrm{R} \$ 11,40$ & 0,16 & $\mathrm{R} \$ 570,00$ & 3,04 & 11,86 \\
Toner preto & 72 & $\mathrm{R} \$ 9,20$ & 0,16 & $\mathrm{R} \$ 230,00$ & 6,07 & 11,86 \\
Papel A4 pct. Com 500 fls & 540 & $\mathrm{R} \$ 2,50$ & 0,17 & $\mathrm{R} \$ 17,40$ & 29,94 & 18,03 \\
Papel gráfico grande formatos & 72 & $\mathrm{R} \$ 11,25$ & 0,29 & $\mathrm{R} \$ 125,00$ & 6,70 & 10,74 \\
Percalux & 32,4 & $\mathrm{R} \$ 32,18$ & 0,23 & $\mathrm{R} \$ 247,50$ & 6,11 & 5,31 \\
\hline
\end{tabular}

Tabela 2 - Lote econômico de compra

Fonte: Elaborado pelos autores

Através da análise da Tabela 2 onde estão exibidos os valores das variáveis que compõem o cálculo do lote econômico de compra $\left(Q^{*}\right)$ e o número de pedidos a se fazer ao ano $(N)$, ressalta-se que o valor de i foi estipulado levando em consideração o custo do aluguel da empresa e qual a porcentagem que o estoque de cada um dos itens representa quanto a espaço e custo. Em vista disso, os resultados obtidos para os valores de lote econômico apresentam alterações pertinentes para três dos cinco itens analisados.

Para os dois primeiros itens, participantes da classe $A$, nota-se que a empresa já realiza o seu pedido com o tamanho de lote econômico de compra obtido no cálculo. A Tabela 3 apresenta a comparação entre os valores de $Q^{*}$ e $N$ utilizados atualmente pela empresa e os propostos pelo estudo.

\begin{tabular}{lcccc}
\hline \multicolumn{1}{c}{ Itens } & Gestão de estoque atual & \multicolumn{2}{c}{ Gestão de estoque proposta } \\
\hline Tonner Cores & $\mathbf{Q}^{*}$ & $\mathbf{N}$ & $\mathbf{Q}^{*}$ & $\mathbf{N}$ \\
Tonner Preto & 3 & 12 & 3 & 12 \\
Papel A4 pct. com 500fls & 6 & 12 & 6 & 12 \\
Papel gráfico grandes formatos & 45 & 12 & 30 & 18 \\
Percalux & 6 & 12 & 7 & 11 \\
\hline
\end{tabular}

Tabela 3 - Gestão de estoque

Fonte: Elaborado pelos autores

Observa-se que os itens participantes da classe $B$, apresentam como resultado do lote econômico de compra um valor diferente ao que é praticado pela empresa. Para o pacote de papel A4 com 500 folhas o pedido deve ser realizado a cada três semanas com uma quantidade de 30 unidades, para o papel 
gráfico grandes formatos deve-se pedir sete unidades a cada cinco semanas e para o percalux sugerese que um pedido de sete unidades seja realizado a cada dez semanas, sendo está última sugestão a que mais se distância do que é praticado pela empresa atualmente.

\section{CONSIDERAÇÕES FINAIS}

Com a aplicação do método $A B C$ foi possível identificar os insumos mais importantes para uma empresa do ramo de gráfica digital em Santa Maria - RS e calcular o lote econômico de compra para esses itens. Tendo como premissa a importância de se gerir estoques e realizar os pedidos de compra em quantidades adequadas e com a periodicidade certa, o estudo favoreceu aos autores sugerir melhorias significativas para e empresa.

Dessa forma, para sanar o custo atrelado a má gestão de estoque foi comparada a frequência e o tamanho dos pedidos realizados atualmente pela empresa com o tamanho do lote econômico. Nesse sentido, observou-se que para os dois primeiros itens analisados, o cálculo aponta como lote econômico de compra o valor que já é adotado pela empresa, para os dois itens subsequentes o resultado não foi significativo, ficando muito próximo do adotado pela empresa. Entretanto, o último item, que é o percalux, a sugestão foi significativa, onde o tamanho do lote passaria de três unidades para dez unidades e a frequência passaria de quatro a dez semanas.

Somado a essa mehoria, através deste estudo o poder de decisão de compra, que antes era concentrado no proprietário, passa a ser de conhecimento de todos os colaboradores da empresa. Deixando a organização com maior autonomia e automatizando o sistema de compras sem o risco de aumentar os custos com compras equivocadas.

O trabalho aponta lacunas para estudos futuros, tanto na área de custos quanto na área de gestão física do estoque, tais como: (1) a ampliação do estudo para os demais produtos da empresa; (2) o uso de mais dados históricos da empresa; (3) estudo mais aprofundado das alternativas de compra, podendo ser estudado de forma mais profunda os fornecedores da empresa. 


\section{REFERÊNCIAS}

CHING, H. Y. Gestão de estoques na cadeia de logística integrada - Supply Chain. 4. ed. São Paulo: Atlas, 2010.

FERREIRA, R.; GUERREIRO, K. M. S. Política de estoque: um estudo de caso na empresa X. Revista Global Manager Acadêmica, v. 2, n. 2, 2013.

GARCIA, E. S.; REIS, L. M. T. V.; MACHADO, L. R.; FERREIRA FILHO, V. J. M. Gestão de estoques: otimizando a logística e a cadeia de suprimentos. Rio de Janeiro: e-papers, 2006.

PAOLESCHI, B. Almoxarifado e gestão de estoques. 2. ed. São Paulo: Editora Érica, 2014.

PEREIRA, M. O uso da curva $A B C$ nas empresas. Disponível em:

<http://www.ivansantos.com.br/ousoABC.pdf> Acesso em: 03 de julho de 2016.

ROGERS, P.; RIBEIRO, K. C. S.; ROGERS, D. Avaliando o risco na gestão financeira de estoques. In: SIMPÓSIO DE ADMINISTRAÇÃO DA PRODUÇÃO, LOGÍSTICA E OPERAÇÕES INTERNACIONAIS, 4. Anais... São Paulo: SIMPOI, 2004.

SANTORO; M. C.; FREIRE, G. Análise comparativa entre modelos de estoque. Revista Produção, v. 18, n. 1, p. 89-98, Jan./Abr. 2008.

SEBRAE. Serviço Brasileiro de Apoio ás Micros e Pequenas Empresas. Estudo setorial da indústria gráfica no Brasil. São Paulo: ABIGRAF, 2009. Disponível em:

<http://www.setorgrafico.org.br/enquadramento_sindical/Estudo\%20Setorial\%20da\%20Ind\%C3\%B Astria\%20Gr\%C3\%A1fica\%20no\%20Brasil-Sebrae.pdf>. Acesso em 2 de junho de 2016.

SILVA, R. P. A contribuição da curva abc para a composição das políticas de estoques. In: SIMPÓSIO DE ENGENHARIA DE PRODUÇÃO, 21. Anais... São Paulo: SIMPEP, 2014.

SMA. (org). Secretaria do Estado do Meio Ambiente. Guia técnico ambiental da indústria gráfica. São Paulo: ABIGRAF, 2009. Disponível em: <file:///D:/Downloads/guia_ambiental_

setorgrafico1.pdf>. Acesso em 2 de junho de 2016.

WANKE, P. Gestão de estoques na cadeia de suprimentos. 3. ed. São Paulo: Atlas, 2011. 


\section{Capítulo 7}

UMA NOVA ABORDAGEM PARA INTERVENÇÕES SUSTENTÁVEIS EM PAISAGENS HISTÓRICAS URBANAS: ENGENHARIA TERRITORIAL

Lucas Cézar Santana Ferreira

Yaeko Yamashita

Joaquim Jose Guilherme de Aragao
Universidade de Brasília

Universidade de Brasília

Universidade de Brasília 
Resumo: O artigo foca em uma nova abordagem para o financiamento de projetos de intervenção em paisagens históricas urbanas. Cultural e historicamente relevantes para as cidades, essas áreas sofrem uma desvalorização devido ao crescimento e as novas dinâmicas territoriais que surgem. Por décadas, o planejamento desenvolveu e implementou propostas intervencionistas de reciclagem desses espaços, muitas vezes em prol do desenvolvimento sustentável. Baseadas em recomendações específicas e oficiais de diversos órgãos internacionais e federativos, os projetos sempre estimularam uma economia turística. Todavia, essa visão provoca um crescimento fragmentado, de fluxo fiscal insustentável e descontínuo, retornando essas áreas ao contexto original. Através da metodologia sistêmica da Engenharia Territorial (ET), e do conceito da Economia Criativa, explorou-se as cadeias de valor no território, e seus elos de negócios, dentro do entendimento de elaboração de um Programa Territorial. Composto por projetos produtivos, complementares, de infraestruturas e integrativos, o Programa apresenta uma complexidade e diversidade de setores e atividades criativas que podem fornecer robustez aos projetos de intervenção nessas áreas. Contabilizou-se cerca de 200 negó-cios entre produção de bens e serviços criativos que podem ser geridos na área de in-tervenção. Concluiuse que é necessária uma Empresa de Desenvolvimento Territorial, como novo agente gerenciador do programa territorial.

Palavras-Chave: Paisagens históricas urbanas; Intervenção urbana; Engenharia Terri-torial; Economia Criativa. 


\section{INTRODUÇÃO}

A reestruturação produtiva de espaços urbanos degradados tornou-se ação comum para o alcance ao desenvolvimento sustentável. Repensar sobre um ambiente desvalorizado e induzi-lo a novas ocupações e usos é uma forma de reciclá-lo, reaproveitando os recursos do espaço já construído e garantindo sua sobrevivência para as gerações futuras (Bezerra, 2018). O Relatório de Brundtland (1987) já considerava que as ações sobre áreas históricas, auxiliaria no progresso sustentável em que novos usos seriam dados a prédios abandonados, os protegendo de demolições ou reconstruções. Anos depois, a Agenda 2030 fomentou que a coesão de comunidades de assentamento humanos deveria estimular inovação e empregos, considerando essa uma discussão a ser tratada melhor na Nova Agenda Urbana (Nações Unidas, 2015).

A Nova Agenda Urbana, resultante da Conferência de Quito em 2017, considerou a importância do planejamento urbano de promover a renovação, regeneração e retrofit-ting das áreas urbanas degradadas ou desvalorizadas como uma ação provedora de integração desses espaços ao restante da cidade, evitando marginalização e expansões desordenadas (Nações Unidas, 2017). Repletos de significados e identidades, os centros ou conjuntos históricos são exemplos de ambientes que precisam dessas intervenções.

Sob esta perspectiva, o planejamento urbano vem há décadas aplicando intervenções nessas áreas por meio de requalificações, revitalizações e/ou renovações urbanas. Na tentativa de preservar e resguardar essas áreas nas dinâmicas urbanas, essas abordagens, por mais que se diferenciem em conceito, recaem em uma execução de projetos urbanos focados no crescimento econômico turístico. Harvey $(2006 ;$ 2014) e Soja (2008) discutem criticamente como que a reestruturação de centros antigos, por exemplo, têm se pautado em uma exploração do capitalismo e têm gerado exclusão e desigualdades sociais. Os projetos de intervenção urbana nesses contextos parecem seguir um processo cíclico em que a questão econômica permanece incipiente e discrepante à realidade local. Indaga-se então quais instrumentos o planejamento urbano pode se utilizar para transformação dessas áreas em prol de sua sustentabilidade?

A pesquisa busca uma nova abordagem que pode emergir a respeito da implementação das intervenções em paisagens históricas urbanas, enfatizando a esfera econômica regional para a garantia da sua sustentabilidade. Assim, um Programa Territorial de Intervenção em Paisagens Históricas Urbanas, desenvolvido sob viés sistemático da Engenharia Territorial (ET), que explora as cadeias de valor do território, gerando rendas locais, garantiria a sustentabilidade do patrimônio 
histórico por meio dos seus negócios. Acredita-se que caso houvesse foco em um desenvolvimento econômico endógeno, onde reconhece-se as potencialidades e oportunidades daquele território, poder-se-ia provocar o setor privado para realizar tais intervenções. É característico a exaustão do poder público em gerenciar essas áreas, havendo grande dispêndio de energia e dinheiro, assim como de empresas privadas que não alcançam o retorno econômico pretendidos, levando novamente a sua degradação.

Intenciona-se refletir sobre a dinâmica fragmentada entre a teoria e a prática das ações de intervenção das paisagens históricas urbanas, principalmente no que concerne à sua viabilização financeira, econômica, social e fiscal. A pesquisa tem como objeto de estudo a viabilização de uma intervenção das paisagens históricas urbanas por meio da exploração das potencialidades econômicas do território, através da atração de investimentos e negócios inseridos dentro de uma cadeia de valor integrada à intervenção pretendida.

$\mathrm{O}$ artigo, inicialmente, discute os conceitos históricos sobre os tipos de abordagens recorrentes aos projetos de intervenção no recorte urbano tratado; depois analisa o aparato documental teórico e específico ao tema de intervenções produzido pelas principais instituições que recomendam e orientam as ações nessas áreas. Nesse momento, esclarece-se o quanto que as abordagens dos projetos, independentemente de sua categoria, se amparam em uma exploração turística. Em seguida, apresentam-se apontamentos para uma abordagem alternativa que dê luz a problematização econômica dessas áreas. Indica-se o conceito de Economia Criativa como um setor robusto e complexo que cresce e já existe no território; e fundamenta-se a Engenharia Territorial como uma metodologia sistêmica e propositiva que direciona novas formas de financiamentos aos projetos urbanos, sob a visão de exploração de cadeias de valor. Discorre-se, posteriormente, sobre a coalizão desses dois elementos visualizando-se como que os setores criativos, tanto de produção quanto de serviços, podem ser capazes de induzir e atrair novos investimentos para as paisagens históricas urbanas provocando sustentabilidade e dinamização.

\section{OS CONCEITOS SOBRE INTERVENÇÕES URBANAS}

Reconhece-se a importância de conjuntos históricos desde meados do século passado onde inúmeras políticas de intervenção urbana foram implantadas para propiciar uma melhor qualidade desses espaços. Ao longo dos anos as políticas para melhoria dos espaços e áreas centrais foram mudando, e receberam diferentes nomenclaturas e enfoques. Na tabela 1, apresentam-se os principais tipos de 
abordagens e suas principais características encontradas na literatura de Medeiros (2015), Vargas e Castilho (2009) e Lawrence, Turgut e Kellet (2012).

Tabela 1: Principais abordagens de intervenção urbana e suas características.

\begin{tabular}{|c|c|}
\hline Tipo de abordagem & Características principais \\
\hline Renovação Urbana & $\begin{array}{l}\text { - Difundido no período entre anos } 50 \text { até os anos } 70 \text { do século passado } \\
\text { na Europa; } \\
\text { - Prática da reconstrução do pós-guerra, a demolição de quarteirões } \\
\text { para a construção de novos espaços; } \\
\text { - Ficou marcada pela gentrificação, com a grande expulsão da } \\
\text { comunidade de baixa renda; } \\
\text { - Transforma e renova as estruturas antigas alinhando-as a dinâmicas } \\
\text { sociais da época, utilizando-se por vezes do conceito de revitalização, } \\
\text { onde pouco dá-se ênfase às esferas sociais e ambientais. }\end{array}$ \\
\hline Preservação Urbana & $\begin{array}{l}\text { - Ocorreu entre } 1970 \text { até } 1990 \text {; } \\
\text { - Ressalta a importância da preservação e restauração dos edifícios } \\
\text { históricos, o período também foi cheio de normatizações que visavam } \\
\text { salvaguardar os centros. }\end{array}$ \\
\hline Reinvenção Urbana & $\begin{array}{l}\text { - Difundida entre } 1980 \text { e } 2000 \text {; } \\
\text { - Foi utilizada devido a implantação de um modo de produção mais } \\
\text { flexível, onde a ascensão da informática e dos meios de comunicação o } \\
\text { território acabou se tornando uma mercadoria a ser consumida, e a } \\
\text { globalização mudou a imagem das cidades. }\end{array}$ \\
\hline Regeneração Urbana & $\begin{array}{l}\text { - Terminologia preocupada com a conservação e preservação de } \\
\text { edifícios e lugares, preocupada com a integração da participação social } \\
\text { e o meio-ambiente. }\end{array}$ \\
\hline $\begin{array}{l}\text { Reciclagem/Reutilização } \\
\text { Urbana }\end{array}$ & $\begin{array}{l}\text { - Busca a permanência da estrutura urbana existente independente da } \\
\text { alteração de sua função, considerando assim um novo clico de vida de } \\
\text { determinada área }\end{array}$ \\
\hline Revitalização Urbana & $\begin{array}{l}\text { - Interferência em um espaço urbano considerado deteriorado social, } \\
\text { econômico e culturalmente, com foco na dimensão material e } \\
\text { econômica, visando a melhoria do espaço e permitindo que ele gere } \\
\text { renda e consumo }\end{array}$ \\
\hline Requalificação Urbana & $\begin{array}{l}\text { - Soma os aspectos da revitalização, com o caráter social e ambiental, } \\
\text { além de abranger parcerias entre a iniciativa pública e privada. } \\
\text { - Tem visão multidisciplinar de estratégias e ações amplas, não só de } \\
\text { preservação histórica; } \\
\text { - Objetiva um futuro físico, econômico e social de grande impacto na } \\
\text { vida das pessoas, nas tradições locais e na qualidade de vida. }\end{array}$ \\
\hline
\end{tabular}

Fonte: elaboração própria.

O propósito de exposição dessas terminologias aqui é para evidenciar que independente dos processos de intervenção urbana, sua maioria passa por um processo de ascensão e declínio, retomando aos aspectos de desvalorização do espaço urbano com o passar dos anos. Acserald (2009) discorre como que essa desvalorização pode estar associada a uma despolitização desses espaços que 
por receberem gestões urbanas preocupadas apenas em atender uma demanda hegemônica global, caracterizada pelo consumo turístico, deslegitima as relações socioculturais originais.

Harvey (2014) analisa que a insistência dessas ações urbanas em áreas de contexto histórico, ou de cidades antigas, quase sempre reverberam a criação de nichos mercadológicos, passando por um boom imobiliário, voltados para o consumo e para a vivência de experiências culturais. $O$ autor destaca que a espetacularização desses espaços está muito mais preocupada com a competição entre as cidades globais, que disputam turistas, do que com o direito à cidade para os cidadãos ou às importâncias de outros aspectos relevantes a dinâmica urbana.

A escolha do tipo de abordagem das conceituações de intervenção urbana pode inferir diretamente na objetivação do projeto. Apesar da abordagem de requalificação urbana, ser comumente escolhida como tipo de intervenção nos centros, devido à multiplicidade de fatores contemplados, essa por si só não garante a efetividade da transformação no meio urbano, e nem sempre é adequada. Entendese nessa postura que, o tipo de abordagem adotado nos projetos de intervenção, devam ser compatíveis com o diagnóstico de problemas e necessidades, e com o prognóstico desejado. Adotarse-á nesta investigação o termo "intervenção urbana" como o mais genérico e coerente para projetos dessa categoria.

Em sua maioria essas novas transformações do meio urbano seguem documentos oficiais, produtos de congressos e convenções mundiais que criam e corroboram conceitos fundamentais para a correta e mais apropriada intervenção no território. Essas diretrizes são decorrentes de teorias que dão suporte ao caráter estrutural e paisagístico das edificações dos conjuntos históricos, mas pouco se aprofundam no contexto regional, menos ainda na dinâmica econômico-financeira dos projetos a serem executados.

\section{AS LACUNAS NAS RECOMENDAÇÕES OFICIAIS}

Os documentos existentes que orientam a realização das intervenções urbanas nestes centros históricos apresentam muitas vezes apenas diretrizes e estratégias gerais de como tais devem ser feitas. A Organização das Nações Unidas para a Educação, a Ciência e a Cultura - UNESCO é a representante em nível mundial da salvaguarda dos patrimônios culturais, incluindo das paisagens históricas urbanas. Suas reuniões com representantes de cada região do mundo produzem manuais de referências, recomendações e relatórios identificando amplos objetivos para a preservação e conservação dos conjuntos listados (Unesco, 2011). 
Em sua maioria, são expostos itens orientados para as restaurações das edificações ou conjuntos históricos em conformidade às cartas patrimoniais. Observa-se nestes uma grande preocupação com os aspectos estéticos da preservação e conservação das edificações históricas, mas um tom generalista quanto ao crescimento econômico das regiões às quais pertencem. Apenas às vezes, são levantadas recomendações quanto ao reconhecimento da dinâmica sócio espacial existente, defendendo-se uma economia regional, adaptada aos sítios e a população local.

Em 2011, por exemplo, a Conferência Geral de Paris gerou recomendações quanto a paisagens históricas urbanas tangendo a abordagem econômica a um instrumento financeiro:

“... os quais devem visar o reforço das capacidades e o apoio a um desenvolvimento inovador e gerador de receitas, alicerçado na tradição. Para além do financiamento público e dos fundos provenientes de organismos internacionais, os instrumentos financeiros devem ser utilizados de forma eficaz para fomentar o investimento privado em nível local. O microcrédito e outras formas flexíveis de financiamento destinadas a apoiar as empresas locais, assim como diferentes modelos de parcerias, são igualmente determinantes para que a abordagem da paisagem histórica urbana seja financeiramente sustentável (Unesco, 2011, p. 6)."

“... os quais devem visar o reforço das capacidades e o apoio a um desenvolvimento inovador e gerador de receitas, alicerçado na tradição. Para além do financiamento público e dos fundos provenientes de organismos internacionais, os instrumentos financeiros devem ser utilizados de forma eficaz para fomentar o investimento privado em nível local. O microcrédito e outras formas flexíveis de financiamento destinadas a apoiar as empresas locais, assim como diferentes modelos de parcerias, são igualmente determinantes para que a abordagem da paisagem histórica urbana seja financeiramente sustentável (Unesco, 2011, p. 6)."

Instrumentos como Incentivos Fiscais e Financeiros, que subsidiam a implantação de empreendimentos culturais e de serviços vinculados ao turismo; a Concessão Especial para fins de moradia, que pretende promover a permanência da população local; o Direito de Superfície, aplicado através da Lei da Contrapartida, desde que haja a autorização do IPHAC e do IPHAN já estão sendo utilizados na área central (Brasil, 2008, p. 70).

Atualmente, o programa de reabilitação da área do Pelourinho, se encontra em nova etapa, de abordagem mais ampla, integrada a dinâmica de toda a cidade e com aspectos mais contundentes a solução dos conflitos de moradia (PROJETO, 2014). Ainda assim, em meio ao dispêndio de energia para elaboração e execução das propostas, perpetuasse as parcerias público-privadas assinaladas na região com grandes gastos públicos sem retorno fiscal. 
Diante da hegemonia instaurada, a reformulação estética das paisagens históricas provoca certa vitalidade, impulsionados pelo turismo predatório - vide a argumentação de Harvey (2006; 2014) -, mas logo decaem à ociosidade urbana e à decadência econômica. Neste, recai, novamente, ao setor público a execução de grande parte dos projetos de intervenção, e mesmo quando são realizados em parceria com o setor privado, há um saldo negativo para todos os agentes - sem garantia de retorno, seja econômico ou social. É um processo cíclico que se esgota e inicia-se repetidamente.

Ficando assim, evidente a necessidade de uma abordagem mais eficiente com sustentabilidade econômica e continuidade da dinâmica das paisagens históricas urbanas, questiona-se de que maneira as mesmas possam ser intervindas em que o setor privado seja responsável por sua implementação e possa fomentar a dinamização e continuidade das funcionalidades na região?

\section{APONTAMENTOS PARA UMA NOVA ABORDAGEM ECONÔMICA}

Propõe-se que a realização das intervenções em paisagens históricas pode ser feita pelo setor privado, quando quase todos os Estados se encontram em crise financeira, no instante em que se há domínio e conhecimento das cadeias de valor do território, tornando-o mais atrativo. A abordagem da Engenharia Territorial permite o alcance a sustentabilidade econômica e eficiência sistêmica, apoiada no entendimento da Economia Criativa.

Nesta seção são apresentadas as discussões que fundamentam a proposta do estudo a Engenharia Territorial e a Economia Criativa.

\subsection{A ECONOMIA CRIATIVA NAS PAISAGENS HISTÓRICAS URBANAS}

Nessas regiões, devido ao conjunto histórico-cultural e as atividades ali desempenhadas, pode ser propício a presença de uma economia baseada em valores culturais. Denominada de Economia Criativa, essa categoria foca na criatividade e inovação e apresenta diversos setores como artes, mídias e criações funcionais que se relacionam entre si através da fruição e do lazer. Baseado nisto, a investigação busca intervir nesses contextos de maneira a valorizar seus aspectos históricos e econômicos.

Economias e indústrias culturais foram recentemente descritas como economias criativas. Criatividade é o conceito básico que combina cultura com ciência, tecnologia e economia. Os conceitos de criatividade econômica, criatividade tecnológica e criatividade artística/cultural, que são tratados separadamente uns dos outros, passam a ser considerados sob o título de economia criativa. A 
interação multifacetada e obrigatória entre esses fenômenos leva ao surgimento de criações contemporâneas. Assim, tenta-se aumentar a qualidade comercial, enfatizando a dimensão criatividade da cultura.

Castells (2005) afirma que essa nova economia é moldada nos setores de tecnologia da informação e finanças, que oferecem um modelo de empreendedorismo em desenvolvimento, produzindo inovações. Além do uso efetivo do conhecimento, economia do conhecimento; incentiva o empreendedorismo e a criação de uma comunidade de pessoas talentosas, flexíveis e criativas (Uçkan, 2006).

A nova economia, segundo Hartley (2005), oferece oportunidades para culturas e iniciativas locais, ao mesmo tempo em que permite iniciativas independentes de infraestrutura e espaço, baseadas em preferências de estilo de vida, como a indústria de jogos digitais. O autor afirma que, por causa dessa linha de desenvolvimento, os círculos acadêmicos e os governos se concentram nas indústrias criativas. De uma perspectiva política econômica, afirma-se que as indústrias criativas se tornaram significativas apenas nas políticas da sociedade da informação (Garnham, 2005).

As economias criativas contribuem para o desenvolvimento econômico sustentável dos países. A legislação da Conferência das Nações Unidas sobre Comércio e Desenvolvimento - UNCTAD (2012) trata especificamente dos países em desenvolvimento para fazer um desenvolvimento econômico sustentável com seus próprios tesouros culturais. A fim de alcançar e gerenciar os desenvolvimentos no campo da economia ou setores culturais, é necessário primeiro fornecer um banco de dados estatísticos e uma nova estruturação administrativa e acadêmica.

Para este fim, a UNCTAD (2012) produz dados digitais sob 9 títulos principais: patrimônio cultural, impressão e literatura, música, artes cênicas, mídia de auditório, mídia audiovisual, atividades socioculturais, esportes e jogos, meio ambiente e natureza, identificando cinco interseções de produção cultural na forma de criação, produção, distribuição, consumo e conservação.

Embora a conexão entre patrimônio e turismo cultural seja bastante arraigada, é inédito avaliar juntos no contexto da indústria cultural. Pode-se dizer que as convenções do Patrimônio Cultural da UNESCO da década de 1970 desempenharam um papel importante no estabelecimento dessa conexão. Assim como, a Convenção sobre Patrimônio Cultural Imaterial, que se difundiu desde o início dos anos 2000 que prevê o fortalecimento e a eficácia do turismo cultural. 
O Comitê Europeu Econômico e Social (2006) aponta que a cultura para todos os países é o motor do turismo. A partir desse entendimento, já foram realizadas intervenções em paisagens históricas que alinham ambos os setores, inclusive focalizados na Economia Criativa.

O estudo de Jesus (2017) identificou que em Lisboa e no Rio de Janeiro, projetos de renovações urbanas já foram implementados com viés de desenvolvimento da economia criativa, mas que não houve um resultado positivo para o contexto local. Conforme o autor, os projetos careceram de aspectos que abordassem a integração territorial, assim como afastou estímulos para o engajamento da população com as atividades dos setores criativos.

Mundialmente, diversos agrupamentos da economia criativa são criados, sempre de acordo com a existência e a exigência do mercado econômico em cada país. Na União Europeia, por exemplo, há a distinção de setores culturais e criativos, dos quais competem atividades industriais (como cinema e vídeo, televisão e rádio, videogames e música, livros e impressões) e não industriais - produção baseada em propriedade intelectual, uso da criatividade, representação (como arquitetura, publicidade, design de moda, gráfico, interiores).

No Brasil, a Federação das Indústrias do Estado do Rio de Janeiro - FIRJAN (2019) apontou que a participação das indústrias criativas no PIB do país representa 2,61\% em 2017, um valor praticamente estável ao longo de quatro anos. Em São Paulo, Rio de Janeiro e no Distrito Federal, essa porcentagem ultrapassa mais de 3\%. Esse é um indicativo de que as empresas estão cada vez mais voltadas para a inovação e demandando trabalhadores criativos. Vale ressaltar que os 3 estados citados possuem áreas consideradas paisagens históricas urbanas delimitadas em suas capitais e demais cidades do interior, o que já antecipa a importância desse setor para a economia local.

\subsection{A ABORDAGEM DA ENGENHARIA TERRITORIAL}

Impulsionados pela crescente crítica e desenvolvimento de projetos de grande infraestrutura, Aragão et al (2008) exploram um conjunto de aspectos jurídicos, financeiros, políticos e projetuais que corroboram a visão fragmentada existente desde a concepção e operação desses investimentos. Principalmente, em seus termos econômicos os autores defendem um crescimento capitalizado voltado precisamente a "sua parcela capturável pelo Poder Público, que seria a via mais consequente de avaliação e de financiamento, até porque contrapõe ao encargo coletivo de todos os contribuintes um retorno de que essa coletividade, de uma forma ou outra, irá se beneficiar, que é o crescimento" (p. 02). 
Esse cenário analítico, debruça-se sobre a abordagem de Causalidade Circular Cumulativa (CCC), desenvolvida por Myrdal (1972), Kapp (1976) e O’Hara (2009), como uma metodologia teórica de visão integradora, cujo princípios entendem um ciclo virtuoso de fatos que desencadeiam outros fatos, de forma cumulativa e motora. Correlacionando-se ao crescimento econômico, os autores fundamentam a Engenharia Territorial que propõe, sistematicamente, um processo espiral de acumulação que atende desde uma conjunção de atores, seus recursos e seus projetos passando por diferentes estágios até o empoderamento estimulador para transformações sociais (Aragão, 2016).

Os estudos de Bracarense (2017) e Freitas (2018) são exemplos de análises e discussões pragmáticas que aplicaram a abordagem da Engenharia Territorial. Sob um complexo de problemas geográficos, econômicos, institucionais e financeiros dos projetos de infraestruturas nos setores hidroviários e ferroviários, as autoras utilizaram-se do quadro sistêmico de campos de ação da ET para propor soluções integradoras. O quadro compõe-se por:

a) programas integrados de investimento em infraestrutura e produção de bens e serviços, assim como de serviços públicos, onde na Figura 1 é denominado de Programa Territorial;

b) fluxos econômicos a produzir e se controlar por meio dos investimentos, geração de renda e de fluxos logísticos e arrecadação fiscal; e

c) uma série de subcampos de políticas indispensáveis para colocar em marcha esse programa enquanto "acelerador". Tais políticas visarão a criação do ambiente institucional, político, cultural e inovação tecnológica para a introdução de programas territoriais na nossa cultura.

A Figura 1 representa o complexo de elementos do sistema de solução. Esse complexo dá fundamento a uma nova engenharia, denominada de Engenharia Territorial, cujo objetivo é a concepção, implantação e a gestão dos programas territoriais onde ganhos de eficiência sistêmica e eficácia são produzidos pela junção de projetos públicos e/ou privados tanto no setor de infraestruturas, quanto na produção de bens e serviços levando a sustentabilidade econômica do negócio. 
Figura 1: Elementos constituintes da Engenharia Territorial, seus resultados e requisitos de mudanças.

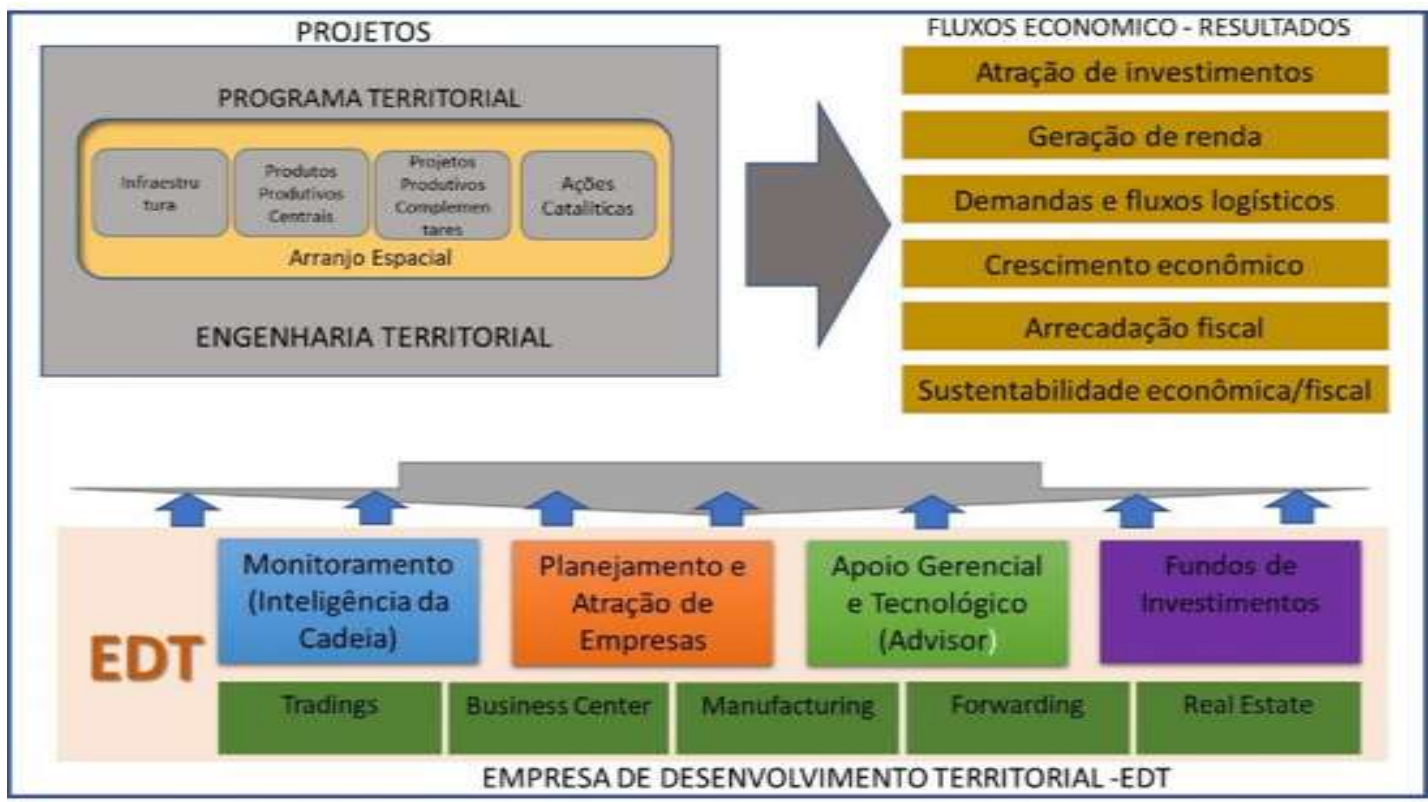

Fonte: adaptado de Aragão, 2008; Aragão et al (2016).

A concepção se baseia na busca da eficiência sistêmica adotando na configuração dos projetos produtivos, a cadeia de valor estratégico de um segmento. Uma cadeia de valor representa o conjunto de atividades desempenhadas por uma organização, desde as relações com os fornecedores e ciclos de produção e de venda até à fase da distribuição final - ver figura 2.

Figura 2: cadeia de valor desenvolvida por Porter.

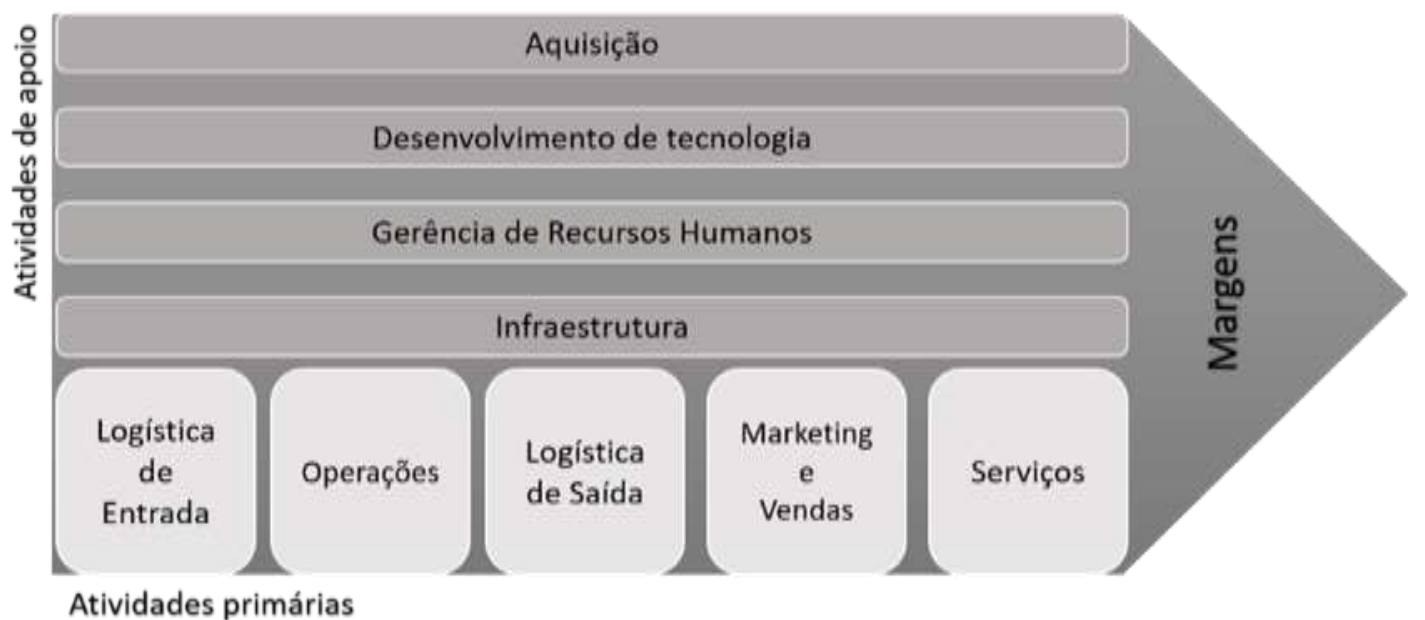

Fonte: adaptado de Porter, 1985.

Para Porter (1985), essa organização permite a melhoria do planejamento estratégico das empresas, onde se identificam aqueles processos de atividades - sejam primárias, sejam de apoio - que não estão 
gerando valor e pode-se potencializar aqueles que estão. Dessa maneira, a geração de valor ao longo das atividades que a empresa realiza pode estabelecer uma vantagem competitiva em comparação a seus rivais. A exploração desses elos e suas atribuições possibilita a visualização de um leque de agentes que estão envolvidos em determinado segmento de atividades, permitindo articulações e interações proveitosas

A implementação compreende a coordenação e o comando geral das mais diversas atividades durante as fases de concepção e execução do programa, como a realização dos estudos, o detalhamento dos projetos e do programa. Seu teste e avaliação com relação aos requisitos estabelecidos, a realização de eventos de discussão, aprovação e institucionalização do programa.

\section{PROGRAMA TERRITORIAL}

O que se espera com o Programa Territorial, por meio da integração de todas as ações, é um resultado sinergético em termos de crescimento de renda que seja suficiente para financiar o próprio empreendimento. Esses programas introduzem na economia um processo de fundamental reorganização do capital, procurando superar a fragmentação das iniciativas dos setores público e privado, assim como produzir ganhos de eficiência sistêmica em escala local, regional ou mesmo nacional. Assim, a Engenharia Territorial, por meio do seu Programa Territorial, busca sustentabilidade econômica gerando impacto econômico, social e ambiental através da atração de investimentos e da geração de renda mediante investimentos privados.

O capitalismo brasileiro enfrenta suas deficiências entre outras a baixa inovação, fragmentação nas suas políticas, nos seus empreendimentos e nos interesses econômicos reinantes. A fragmentação das políticas, nas quais sempre perceberam uma visão micro de potencialidade do território, provocou uma grande dependência do financiamento estatal para suas execuções, desvalorizando inclusive o capital humano, gerando pouca produtividade.

O Programa Territorial por sua vez se caracteriza por um conjunto integrado de intervenções com função de dinamizar o planejamento estratégico e de viabilizar projetos. Esses são concebidos tomando-se como base as diretrizes ambientais, urbanas, sociais e econômicas já regulamentadas nas legislações e planos federais ou estaduais ou municipais, que visualiza dentro de uma cadeia de valor estratégias que garantem a eficiência sistêmica.

Do entendimento do processo da Engenharia Territorial resultam as orientações estratégicas para elaboração do Programa Territorial: 
- Potenciais econômicos regionais: os programas devem partir dos potenciais das economias regionais para se inserirem de forma vantajosa nos mercados nacionais e internacionais;

- Investimento nos elos da cadeia produtiva: visando ampliar os efeitos multiplicadores e refletir ganhos de produtividade em toda a cadeia;

- Agregação de valor na produção local: também com o intuito de fortalecer a economia local/regional;

- Novas necessidades de consumo: trata-se de identificar potenciais ainda não explorados, ou segmentos ainda não atendidos no território;

- Concepção espacial: a fim de conferir vantagem locacional, os projetos devem articular-se otimizando os fluxos e contribuindo para a consolidação do território;

- Número amplo de atores diversificados e empreendedorismo popular: o programa deve contemplar, além de setores dinâmicos, iniciativas que promovam ou favoreçam pequenos empreendimentos, no sentido de distribuir os resultados a mais faixas da sociedade, gerar demanda agregada e aperfeiçoar capital humano;

- Preservação do meio ambiente;

- Fomento à pesquisa e desenvolvimento: a fim de proporcionar ganhos de produtividade e qualidade, aumentando a competitividade da produção e dos serviços do território, desenvolver novas necessidades e mercados, apoiar o desenvolvimento do capital humano e tornar mais eficientes as medidas de preservação ambiental;

- Desenvolvimento do sistema financeiro: no sentido de melhorar a acessibilidade aos serviços, aperfeiçoar a eficiência do mesmo, introduzir inovações nas formas de financiar os projetos e contribuir de uma forma geral para o crescimento econômico mediante a aceleração do processo de acumulação.

O Programa Territorial se compõe de um conjunto integrado de projetos de iniciativa pública e privada em um determinado território que envolve investimentos em plantas produtivas e em infraestruturas. Esses projetos componentes podem ser classificados conforme tabela 2 a seguir. 
Tabela 2: Projetos constituintes do Programa Territorial.

\begin{tabular}{c|l}
\hline $\begin{array}{c}\text { Projetos } \\
\text { Projetos produtivos } \\
\text { motores }\end{array}$ & $\begin{array}{l}\text { Responsáveis pela agregação de valor econômico, portanto suportando a } \\
\text { sustentabilidade fiscal em função dos diversos impactos econômicos que } \\
\text { geram ao longo de toda a cadeia produtiva em que se inserem. }\end{array}$ \\
\hline $\begin{array}{c}\text { Projetos produtivos } \\
\text { complementares }\end{array}$ & $\begin{array}{l}\text { São uma série de projetos de produção de bens ou serviços relacionados com } \\
\text { os primeiros, portanto pertencentes à respectiva cadeia produtiva, de forma a } \\
\text { reforçar a agregação de valor do território do mesmo. }\end{array}$ \\
\hline $\begin{array}{c}\text { Projetos } \\
\text { integrativos }\end{array}$ & $\begin{array}{l}\text { Não pertencem diretamente às cadeias produtivas, mas catalisam sua } \\
\text { agregação de valor e o processo de crescimento geral, abrangendo o } \\
\text { incentivo ao empreendedorismo, a educação e capacitação, à saúde, a } \\
\text { habitação, a vida cultural, desportiva e lazer, a segurança, a promoção social } \\
\text { e a gestão ambiental. }\end{array}$ \\
\hline $\begin{array}{c}\text { Projetos de } \\
\text { infraestrutura }\end{array}$ & $\begin{array}{l}\text { Abrangem o transporte, a logística, e demais infraestruturas técnicas, } \\
\text { promotoras de ganho de produtividade, otimizando a estrutura espacial e de } \\
\text { qualidade ambiental. }\end{array}$ \\
\hline
\end{tabular}

Fonte: adaptado de Aragão, 2008; Aragão et al (2016).

A esses projetos se junta o projeto de arranjo espacial do programa, que abrange todos os projetos listados, de forma a explorar economias espaciais, mas também cumprir requisitos ambientais, sociais e outros objetivos estratégicos políticos e espaciais. O que se objetiva, por meio da integração de todas essas ações, é um resultado sinergético em termos de crescimento da renda que seja suficiente para financiar o conjunto em médio prazo. Tal integração poderia construir a viabilidade conjunta desses projetos assim como de outros investimentos no setor produtivo que deles se beneficiariam e das ações integrativas.

\section{EMPRESA DE DESENVOLVIMENTO TERRITORIAL - EDT}

A Engenharia Territorial integra na sua teoria metodológica a criação de uma Empresa de Desenvolvimento Territorial (EDT) que visa a geração do fluxo e do crescimento econômico. Essa empresa aufere receitas pela prestação de serviços e alocação de espaços e infraestruturas; não produzindo diretamente, mas atraindo, articulando e apoiando os agentes pertencentes aos diversos elos das cadeias de valor globais envolvidas.

Através do reconhecimento das cadeias de valor, sua administração deve ser feita por meio de um trabalho minucioso de composição de espaços empresariais correspondentes, atraindo investidores e empresas, preferivelmente de pequeno e médio porte, para facilitar a obtenção da meta de desempenho correspondente. Onde e quando o conjunto de empresas atraídas ainda não abranger elos tidos como indispensáveis para completar as cadeias definidas, a EDT poderá contratar 
diretamente um empreendimento correspondente, desde que seja essencial para garantir a eficiência sistêmica da intervenção como um todo.

É imprescindível também que a EDT monitore e tome as medidas necessárias para garantir a eficiência e a competitividade daquele território transformado. Para isso, ela terá de:

- Explorar espaços estratégicos de comercialização dos bens e serviços criativos;

- Garantir a qualidade do ambiente físico, de trabalho e urbano;

- Providenciar ações de capacitação e de promoção da inovação, tendo envolvimento da população local;

- Promover um clima de cooperação entre as empresas atraídas e/ou contratadas, mitigando eventuais conflitos que surjam entre as mesmas.

\section{PROPOSTA PARA ELABORAÇÃO DO PROGRAMA TERRITORIAL DE INTERVENÇÕES}

\section{SUSTENTÁVEIS EM PAISAGENS HISTÓRICAS URBANAS}

Na busca pela concepção de novas formas de financiamento que provoquem uma eficiente intervenção das paisagens históricas urbanas, adotou-se a abordagem sistêmica da Engenharia Territorial juntamente com a categorização da Economia Criativa na elaboração da cadeia de valor. Como estrutura para o desenvolvimento de estudo empírico foram realizados os seguintes passos:

a) Identificação da cadeia de valor baseado nas categorias da Economia Criativa para intervenção da Paisagem Histórica;

b) Exploração dos elos de negócios da cadeia de valor a serem aproveitados na intervenção da Paisagem Histórica;

c) Designação dos projetos constituintes do Programa;

d) Desenho institucional para a viabilização das cadeias de valor na intervenção da Paisagem Histórica.

Por análise documental realizada em tópico anterior, identificou-se que o avanço das implementações de projetos de intervenção sempre fora sustentado em uma economia turística. Dessa maneira, reconhece-se que já há grande presença de setores criativos e culturais nos conjuntos históricos todavia, não integrados e não voltados ao melhor desempenho da economia local. 


\subsection{ECONOMIA CRIATIVA E SUA CADEIA DE VALOR}

Pela metodologia de estudos de cadeias globais, indicado pela ET como um instrumento conceptivo, os projetos do programa de intervenção foram divididos em 4: projetos produtivos, complementares, catalizadores e de infraestrutura. Os projetos produtivos correspondem a cadeia da Economia Criativa - referenciada por relatórios da UNC-TAD (2012), Newbigin (2010) e FIRJAN (2019) - nos quais ficaram definidos 4 categorias que abarcam 13 setores criativos, conforme tabela 3.

Tabela 3: Setorização da Economia Criativa.

\begin{tabular}{|c|c|c|c|}
\hline PATRIMÔNIO & ARTES & MIUDIAS & $\begin{array}{l}\text { CRIAÇÖES } \\
\text { FUNCIONAIS }\end{array}$ \\
\hline \multirow{2}{*}{$\begin{array}{l}\text { Expressões } \\
\text { Culturais }\end{array}$} & \multirow{2}{*}{ Música } & Cinema & Arquitetura \\
\hline & & Editorial & Design \\
\hline \multirow{3}{*}{$\begin{array}{c}\text { Artes e } \\
\text { Antiguidades }\end{array}$} & \multirow{3}{*}{ Artes Cênicas } & \multirow[t]{2}{*}{ Televisão e Rádio } & Moda \\
\hline & & & Software \\
\hline & & Publicidade & $\begin{array}{l}\text { Software interativo } \\
\text { (vídeo games) }\end{array}$ \\
\hline
\end{tabular}

Fonte: elaboração própria.

Cada setor propicia uma cadeia com oportunidades de negócios, conforme explorado pelos modelos de Porter (figura 2). Desde micro e pequenas empresas a grandes investidores, os setores investigados são capazes de canalizar para a área de intervenção uma variedade econômica que provoque seu crescimento (pelo levantamento, foram constatados mais de 50 negócios, intrínsecos a Economia Criativa, conforme quadro 1). Entende-se que com a complexidade da rede de mercado, o espaço urbano possa atrair investimentos e sofrer alterações. Estas, se adequadas a sua paisagem histórica, e às condições físicas do seu conjunto edilício (que podem ser adaptados conforme às recomendações técnicas oficiais) possibilitarão a vitalidade econômica necessária para perpetuação daquele ambiente no território.

Isso deve ocorrer com o apoio de uma instituição viabilizadora, a Empresa de Desenvolvimento Territorial de natureza privada, com carácter dinamizadora para que possa dar suporte técnico, administrativo e de gestão garantindo a sustentabilidade econômica e financeira pela sua otimização sistêmica com ganhos em economia de escala e escopo. Acredita-se que isso reestruturaria a paisagem urbana de maneira a dinamizá-la, assim como suas regiões adjacentes. 
Quadro 1: Matriz de projetos produtivos da Economia Criativa.

\begin{tabular}{|c|c|c|c|c|c|c|c|}
\hline \multirow{2}{*}{ Patrimônio } & $\begin{array}{c}\text { Expressões } \\
\text { Culturais }\end{array}$ & \multicolumn{2}{|c|}{ Artesanato } & \multicolumn{2}{|c|}{ Folclore } & \multicolumn{2}{|c|}{ Gastronomia } \\
\hline & $\begin{array}{c}\text { Artes e } \\
\text { Antiguidades }\end{array}$ & \multicolumn{3}{|c|}{ Galerias } & \multicolumn{3}{|c|}{ Restauração } \\
\hline \multirow{2}{*}{ Artes } & Música & Instrumentos & Mídia & \multicolumn{2}{|c|}{ Produção } & \multicolumn{2}{|c|}{ Eventos e Festivais } \\
\hline & Artes Cênicas & Festivais & \multicolumn{2}{|c|}{ Teatro } & \multicolumn{2}{|c|}{ Performance } & Mídias \\
\hline \multirow{4}{*}{ Mídias } & Cinema & Festivais & Mídia & \multicolumn{2}{|c|}{ Produção } & \multicolumn{2}{|c|}{ Arquitetura \& Design } \\
\hline & Editorial & $\begin{array}{l}\text { Produção de } \\
\text { Conteúdo }\end{array}$ & $\begin{array}{l}\text { Aquisição de } \\
\text { Conteúdo }\end{array}$ & $\begin{array}{l}\text { Impressão e } \\
\text { Acabamento }\end{array}$ & $\begin{array}{l}\text { Vendas e } \\
\text { Marketing }\end{array}$ & $\begin{array}{c}\text { Estoque e } \\
\text { Distribuição }\end{array}$ & Comercialização \\
\hline & $\begin{array}{c}\text { Televisão e } \\
\text { Rádio }\end{array}$ & Produção & Programação & \multicolumn{2}{|c|}{ Distribuição } & \multicolumn{2}{|c|}{ Consumo } \\
\hline & Publicidade & $\begin{array}{l}\text { Serviços de } \\
\text { Publicidade }\end{array}$ & \multicolumn{2}{|c|}{ Marketing \& Propaganda } & Mídias & \multicolumn{2}{|c|}{ Industrias Gráficas } \\
\hline \multirow{5}{*}{$\begin{array}{l}\text { Criações } \\
\text { Funcionais }\end{array}$} & Arquitetura & \multicolumn{2}{|c|}{ Serviços de Arquitetura } & Paisagismo & $\begin{array}{l}\text { Espaços } \\
\text { públicos }\end{array}$ & \multicolumn{2}{|c|}{ Espaços construídos } \\
\hline & Design & Design Gráfico & \multicolumn{2}{|c|}{ Design de Produtos } & $\begin{array}{l}\text { Design } \\
\text { Industrial }\end{array}$ & \multicolumn{2}{|c|}{ Web Design } \\
\hline & Moda & Desenho & Matéria-prima & Produção & $\begin{array}{l}\text { Logística/Redes } \\
\text { de Exportação }\end{array}$ & Marketing & $\begin{array}{c}\text { Distribuição de } \\
\text { Vendas }\end{array}$ \\
\hline & Software & Desenvolvimento & Produção & \multicolumn{2}{|c|}{ Marketing e Distribuição } & \multicolumn{2}{|c|}{ Serviços pós-venda } \\
\hline & $\begin{array}{c}\text { Software } \\
\text { interativo } \\
\text { (vídeo games) }\end{array}$ & $\begin{array}{c}\text { Fabricantes de } \\
\text { Software }\end{array}$ & Desenvolvimento & Marketing & Distribuição & & arejista \\
\hline
\end{tabular}

Fonte: elaboração própria.

Os projetos produtivos, que fazem referência a todos os setores criativos, são a base de negócios para a proposta de intervenção para atrair maior quantidade de pessoas garantindo o fluxo financeiro. Cada setor abre um leque de oportunidades de negócios que por si serão responsáveis pela atração de investidores, pela geração de empregos e pelo aumento de produtividade, com apoio da EDT. No quadro 2, é explorado, como exemplo, um setor de cada categoria componente da Economia Criativa (da categoria de Patrimônio, as Expressões Culturais; da categoria de Artes, o setor de Música; da categoria de Mídias, o setor de Publicidade; e da categoria de Criações Funcionais, o setor de Software), permitindo visualizar o quanto de atividades estão inseridas, possibilitando uma diversidade de profissionais e de empresas atuarem naquele território.

Assim como essas, outras cadeias dos outros setores criativos também foram desenvolvidas. Os mais de 50 projetos identificados no quadro 1, através do mesmo procedimento realizado e demonstrado no quadro 2, transformaram-se em cerca de 200 negócios relacionadas a bens e serviços criativos. A proposta é que a extensão da rede de negócios propicie um ambiente competitivo, complexo e diverso, contribuindo para a vitalidade econômica da região, amparada pela atuação da EDT. Quanto maior a robustez da rede de negócios no território, maior será a indução de produtividade, provisionando uma transformação duradoura. 
Quadro 2: Exemplos de cadeias de valor exploradas.

\begin{tabular}{|c|c|c|c|c|}
\hline $\begin{array}{l}\text { Expressões } \\
\text { Culturais }\end{array}$ & $\begin{array}{l}\text { Artesanato } \\
\text { (têxtil, } \\
\text { cerâmica, } \\
\text { joias...) }\end{array}$ & \multicolumn{2}{|c|}{ Folclore (fantasia, cenografia, produção de eventos) } & $\begin{array}{c}\text { Gastronomia (artesanal, } \\
\text { industrial) }\end{array}$ \\
\hline & Matéria-prima & \multicolumn{2}{|c|}{ Design } & Extração natural \\
\hline & Transporte & \multicolumn{2}{|c|}{ Produção } & Produção \\
\hline & Transformações & \multicolumn{2}{|c|}{ Marketing } & Fornecimento \\
\hline & Empacotamento & \multicolumn{2}{|c|}{ Distribuição } & Empacotamento/Armazenamento \\
\hline & Armazenamento & \multicolumn{2}{|c|}{ Espaços Especializados } & Distribuição \\
\hline & Distribuição & \multicolumn{2}{|c|}{ Fornecimento de Estrutura } & Consumo \\
\hline & Exposição & \multicolumn{2}{|c|}{ Uso público } & Exposições \\
\hline \multirow[t]{7}{*}{ Música } & Instrumentos & Produção & Mídias & Eventos e Festivais \\
\hline & Matéria-prima & Gravação & Publicidade & Espaços Especializados \\
\hline & Fabricação & Edição & Distribuição/Exportação & Cenografia \\
\hline & Distribuição & Masterização & Patrocínio & Fornecimento de Estrutura \\
\hline & Comercialização & Formatação & \multirow{2}{*}{ Assessoria de Imprensa } & Comércio A\&B \\
\hline & Manutenção & Execução & & Segurança \\
\hline & Ensino & Selo & Consumo & Limpeza \\
\hline \multirow[t]{7}{*}{ Publicidade } & $\begin{array}{l}\text { Serviços de } \\
\text { Publicidade }\end{array}$ & $\begin{array}{l}\text { Marketing \& } \\
\text { Propaganda }\end{array}$ & Mídias & Industrias Gráficas \\
\hline & Conceituação & Criação & \multirow{2}{*}{ Meios de comunicação } & Indústrias de papel \\
\hline & Criação & Planejamento & & Indústria de embalagens \\
\hline & Desenho & Estratégias de comunicação & TV & Máquinas \\
\hline & Execução interna & Preço & Internet & \multirow{2}{*}{ Produtos industrializados } \\
\hline & \multirow{2}{*}{$\begin{array}{l}\text { Supervisão da } \\
\text { execução }\end{array}$} & Distribuição & Patrocinadores & \\
\hline & & Produtos & Rádio & Indústrias de papel \\
\hline \multirow[t]{5}{*}{ Software } & Concepção & Produção & Marketing e Distribuição & Serviços pós-venda \\
\hline & Conceito & \multirow{2}{*}{ Software de Aplicação } & Venda varejista & Suporte \\
\hline & Desenho & & \multirow{2}{*}{$\begin{array}{c}\text { Venda B2B (bussines to } \\
\text { bussiness) }\end{array}$} & Manutenção \\
\hline & Desenvolvimento & \multirow{2}{*}{ Software de Sistema } & & \multirow{2}{*}{ Treinamento e Certificação } \\
\hline & Teste & & Streaming & \\
\hline
\end{tabular}

Fonte: elaboração própria.

\section{PROGRAMA TERRITORIAL E A EDT}

Em suporte aos projetos produtivos estão os projetos complementares. Estes correspondem aos fornecimentos de materiais, equipamentos e da difusão da própria proposta na região (como o marketing do projeto urbano de intervenção). Em concomitância, os projetos catalizadores são direcionados ao empoderamento da população local e à sua qualificação. Serviços gerais, cooperativismo e educação auxiliarão na catalisação de diferentes parceiros que desempenharão atividades fundamentais para que a economia local possa gerar renda e consumo, direcionando à sustentabilidade dos negócios e motivando o empreendedorismo regional. Por fim, os projetos de 
infraestrutura garantem a robustez das cadeias envolvidas no programa de intervenção urbana. Transporte, comunicação, saneamento, habitação e gestão de resíduos são setores basilares para qualquer projeto urbano e cada qual estabelece uma rede de serviços e industrias. A proposta da Engenharia Territorial é para que a infraestrutura possa ser paga pelas receitas do próprio retorno fiscal em função dos negócios da intervenção.

Em adição, as paisagens históricas urbanas requerem atenção especial aos seus aspectos paisagísticos e das edificações históricas, que devem seguir legislações específicas e requerem serviços especializados. Para uma proposta de intervenção nas paisagens históricas urbanas, os projetos de infraestrutura estão voltados para consolidação, conservação e preservação de um conjunto urbano já existente, que apenas deve ser otimizado. A matriz dos projetos complementares, catalizadores e infraestrutura que geram os seus respectivos negócios são apresentados no quadro 3.

\section{Quadro 3: Matriz dos projetos complementares, catalizadores e de infraestrutura.}

\begin{tabular}{|c|c|c|c|c|c|c|c|c|c|}
\hline \multirow{2}{*}{ 造 } & \multirow{2}{*}{ Fornecimentos } & Matérias-primas & \multicolumn{2}{|c|}{ Equipamentos para eventos } & \multicolumn{2}{|c|}{ Materiais gráficos } & \multicolumn{3}{|c|}{ Materiais de Construção } \\
\hline & & Marketing & \multicolumn{2}{|c|}{$\begin{array}{l}\text { Equipamentos de audiovisual e } \\
\text { iluminação }\end{array}$} & \multicolumn{2}{|c|}{ Equipamentos de T.I. } & \multicolumn{2}{|c|}{ Mobiliários } & Decorações \\
\hline \multirow{3}{*}{ 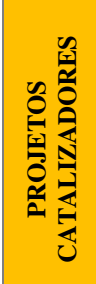 } & Formação & $\begin{array}{l}\text { Qualificação } \\
\text { profissional }\end{array}$ & \multicolumn{2}{|c|}{ Escolas Técnicas } & \multicolumn{5}{|c|}{ Educação Patrimonial } \\
\hline & Empreendedorismo & Certificação & \multicolumn{2}{|c|}{ Serviços de apoio às empresas } & \multicolumn{5}{|c|}{ Associativismo e cooperativismo } \\
\hline & Serviços & Segurança & \multicolumn{2}{|c|}{ Comércio geral } & \multicolumn{5}{|c|}{ Serviços especializados gerais } \\
\hline \multirow{7}{*}{ 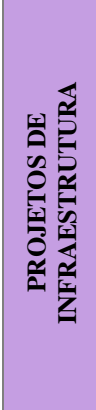 } & Transporte & Vias & Circulação & Terminais & & ciamento & Serv & ge & ais de transporte \\
\hline & Comunicação & Telefonia & \multicolumn{2}{|c|}{ Internet } & & \multicolumn{4}{|c|}{ Postais } \\
\hline & Saneamento & $\begin{array}{c}\text { Abastecimento de } \\
\text { águas }\end{array}$ & \multicolumn{3}{|c|}{ Esgoto e drenagem } & \multicolumn{4}{|c|}{ Lixo } \\
\hline & Habitação & \multicolumn{3}{|c|}{ Setor imobiliário geral } & & \multicolumn{4}{|c|}{ Habitação popular } \\
\hline & Paisagismo & \multicolumn{4}{|c|}{ Paisagismo regional e gestão ambiental } & \multicolumn{4}{|c|}{ Paisagismo Urbano e espaços verdes } \\
\hline & $\begin{array}{l}\text { Edificações } \\
\text { históricas }\end{array}$ & Retrofitting & Restauração & \multicolumn{2}{|c|}{ Revitalização } & \multicolumn{4}{|c|}{ Recuperação } \\
\hline & Gestão de Resíduos & Coleta & Reciclagem & \multicolumn{2}{|c|}{ Transformação } & \multicolumn{2}{|c|}{ Armazenamento } & & Reutilização \\
\hline
\end{tabular}

Fonte: elaboração própria.

Em conformidade à metodologia adotada pela ET, além dos retornos fiscais aos esforços privados promovidos pela EDT, são necessários a indicação de metas finalísticas ao programa de intervenção que promovam desenvolvimento socioambiental. Como propostas de resultados ansiados em retorno 
a sociedade e às políticas públicas governamentais, um Programa Territorial de Intervenções Sustentáveis em Paisagens Históricas Urbanas pode buscar indicadores de:

a) Número de empregos gerados (a depender do território a ser desenvolvido o programa os valores numéricos e porcentagens devem ser adequadas ao diagnóstico de crescimento da região);

b) Número de contratos ou parcerias com pequenas e médias empresas locais;

c) Porcentagem de área ou número de edificações preservadas, conservadas e restauradas, e conformidade de suas adequações com as recomendações patrimoniais oficiais (onde podem ser alocadas as empresas atraídas);

d) Número de programas e projetos culturais catalisados para a região ou a serem criados a partir da implementação do projeto de intervenção;

e) Valores em reais da arrecadação fiscal, que demonstre a suficiência para cobrir as despesas públicas envolvidas; e outros.

O Programa Territorial apresenta-se, então, como uma solução mais robusta, que dá seguimento a diretrizes socioambientais dentro de projetos que buscam agregação de valor aos resultados econômicos, ao longo de cadeias produtivas, gerando rendas e assegurando a sustentabilidade do patrimônio.

Figura 3: Programa Territorial de Intervenções Sustentáveis em Paisagens Históricas Urbanas e a EDT.

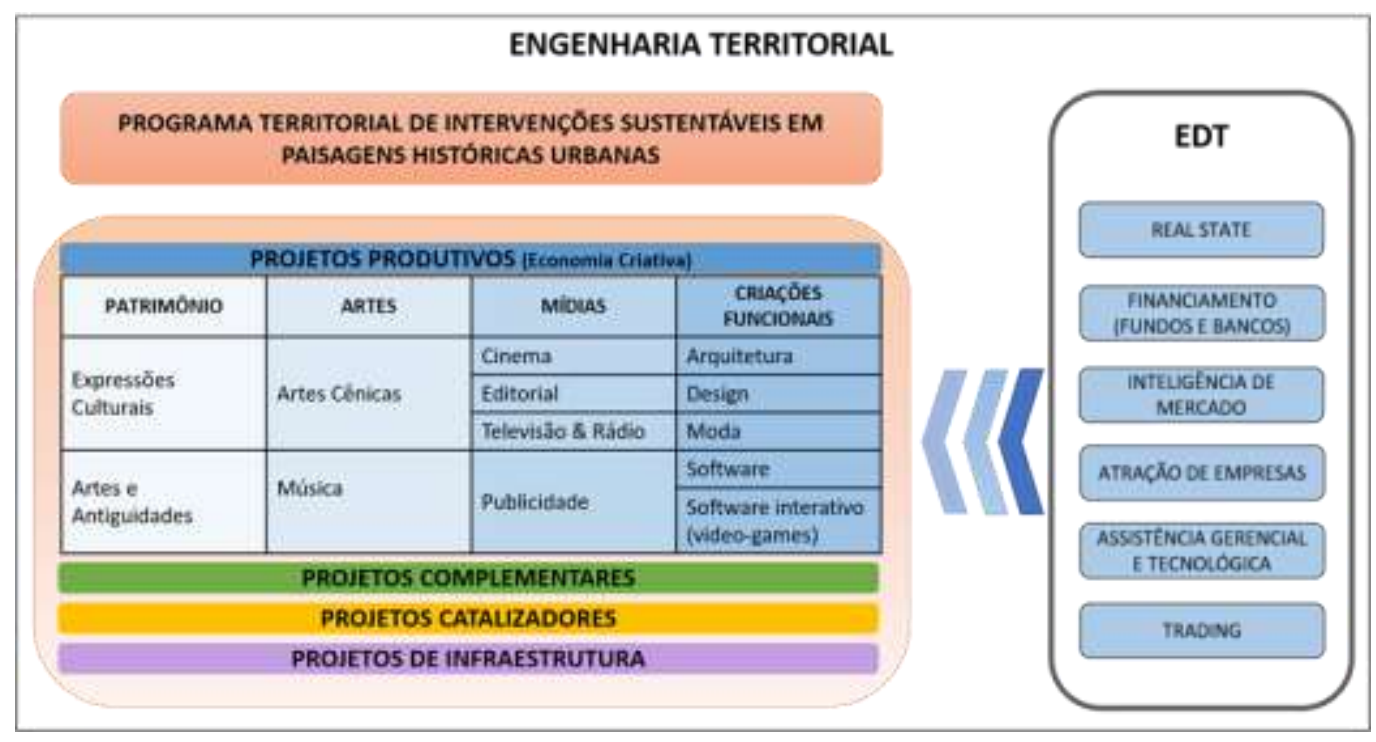

Fonte: elaboração própria. 
Para esse resultado ser obtido, se propõe a criação de uma EDT de caráter privado, conforme a figura 3, que ao dar suporte e acelerar a dinamização da intervenção, por meio do uso de informações estratégicas, apoio administrativo/financeiro e de gestão dos negócios envolvidos, garante os resultados almejados. Assim, a EDT busca a si-nergia entre ações, agentes e atividades e efetiva uma intervenção bem-sucedida.

\section{CONCLUSÕES}

Em pauta no reconhecimento das paisagens históricas como áreas importantes para a dinâmica das cidades, seus projetos de intervenção para preservação e conservação têm grandes questionamentos quanto às ações sociais, econômicas e ambientais. Ao longo das décadas, as teorias pautadas na tecnicidade para a correta operação sobre o patrimônio edificado, gerou grande aparato documental que por mais que reconheçam a interdisciplinaridade das ações, negligenciou o entendimento econômico, provocan-do desempenhos incipientes e insustentáveis. Conforme apontado anteriormente, a abordagem para o crescimento econômico se pauta em uma prática turística que não integra a dinâmica local e não garante uma geração de renda.

Nesse sentido, solicita-se uma nova abordagem de foco econômico, onde novas dire-trizes sejam mais integradoras oferecendo custos transacionais reduzidos para os pro-jetos dessa natureza. Assim, proveniente das referências abordadas, acondicionadas na metodologia da Engenharia Territorial, baseado no entendimento da Economia Criati-va, verificou-se que há uma diversidade de cadeias de valor e atividades que podem ser geridas no território dessas paisagens. Com o levantamento realizado, observou-se que mais de 50 projetos estruturantes e 200 negócios entre produção de bens e serviços criativos, aliadas aos projetos complementares, catalizadores e de infraestrutura po-dem ser geridos em cadeia sob agregação de valor em uma Paisagem Histórica Urbana.

Devido à complexidade dessa intervenção, nota-se que não há um enquadramento ins-titucional e legal que hoje esteja regulamentado, ou em prática, que possa garantir a eficiência sistêmica almejada. Indicou-se a criação de uma Empresa de Desenvolvi-mento Territorial que gerencie a paisagem histórica urbana. Como apontado na ET, esta empresa com o apoio dos fundos de investimentos viabilizaria acelerando às in-tervenções, garantindo uma exitosa dinamização econômica por meio de metas a se-rem cumpridas.

A diversidade de setores criativos e suas inter-relações fortificam a economia local por meio do crescimento econômico endógeno, assistido por uma EDT, que provocará maior vitalidade dos espaços 
públicos e edificados, garantindo que a paisagem do ter-ritório seja preservada e revalorizada. As áreas e os ambientes de prédios históricos não apenas abrigam as experiências culturais, como também acolhem as funções do cotidiano, principalmente o trabalho e a moradia. Se antes essas áreas decaiam na di-nâmica urbana devido ao aparecimento e crescimento de novas centralidades, agora desempenharia um importante papel não apenas simbólico cultural, como também econômico reverberando assim um desenvolvimento sustentável na cidade.

As análises e discussões realizadas apresentam como a economia no espaço urbano pode ser responsável por sua modificação, principalmente quando este requer inter-venções quase que emergenciais para sua recuperação. Resultando-se então uma visão de que a exploração das cadeias globais de valor é capaz de, concomitantemente: di-versificar o mercado e provocar a sustentabilidade fiscal exigida pelo setor privado; conduzir ações socioambientais; e garantir melhorias de qualidade de vida à população por meio da geração de rendas.

\section{AGRADECIMENTOS}

Agradecemos a colaboração de Burkay Koseoglu, Diana Pari, Leticia Lopes e Raphael Sebba que participaram das discussões para formação da proposta apresentada neste artigo, como também ao CNPq- Conselho Nacional de Desenvolvimento Científico e Tecnológico pelas bolsas de apoio a pesquisa. 


\section{REFERÊNCIAS BIBLIOGRÁFICAS}

Acselrad, H. (2009), A duração das cidades: sustentabilidade e risco nas políticas ur-banas, 2 ed, Rio de Janeiro: Lamparina.

Aragão, J. J. G. (2016), "Chutando o Balde do Sec. XX". Disponível em: https://jornalggn.com.br/analise/chutando-o-baldedo-seculo-xx-por-joaquim-aragao/ , acessado em 18 de janeiro de 2020.

Aragão, J. J. G.; Orrico Filho, R. D; Santos, E. M. dos; Morais, A. C. (2008), "Funda-mentos para uma Engenharia Territorial", texto para discussão, CEFTRU, Universida-de de Brasília. Disponível em: http://observatoriogeograficoamericalatina.org.mx/egal12/Teoriaymetodo/Teoricos/26.pdf, acessado em 18 de janeiro de 2020.

Bezerra, M. C. (2018), "Contribuição da gestão de projetos de intervenções urbanas à sustentabilidade ambiental da cidade”, in: G. C. B.; A. P. J. (Eds.), Gestão urbana e sustentabilidade, São Paulo: Manole.

Bracarense, L.S.F.P. (2017), Elementos para um modelo inovador de parcerias públi-co-privadas em infraestrutura de transportes: Estudo aplicado à Hidrovia do Rio To-cantins, Tese de Doutorado em Transportes, Brasília, Universidade de Brasília.

Brundtland, G. H. (1987), Our Common Future: the World Commission on Environ-ment and Development, Oxford University Press. Disponível em: https://sustainabledevelopment.un.org/content/documents/5987our-common-future.pdf, acessado em 20 de janeiro de 2020.

Castells, M. (2005), A Era da Informação: Economia, Sociedade e Cultura, São Paulo: Paz e Terra.

Comitê Europeu Econômico e Social. (2006), Tourism and Culture: two forces for growth. Disponível em: $\quad$ https://eur-lex.europa.eu/LexUriServ/LexUriServ.do?uri=OJ:C:2006:110:0001:0007:EN:PDF, acessado em 25 de janeiro de 2020.

FIRJAN. (2019). Mapeamento da Industria Criativa no Brasil. Disponível em: https://www.firjan.com.br/EconomiaCriativa/downloads/MapeamentolndustriaCriativa.pdf, acessado em 23 de janeiro de 2020.

Garnham, N. (2005), "From Cultural to Creative Industries", International Journal of Cultural Policy, 11, pp. 15-29.

Hartley, J. (2005), Creative Industries, Oxford: Wiley-Blackwell.

Harvey, D. (2006), A produção capitalista do espaço, São Paulo: Annablume Editora.

Harvey, D. (2014), Cidades Rebeldes, São Paulo: Martins Fontes.

Inoue, L. M. (2015). “O patrimônio urbano e as cartas patrimoniais", artigo apresenta-do no 7o Fórum Mestres e Conselheiros - Agentes Multiplicadores do Patrimônio - Patrimônio e Cidades, Belo Horizonte.

Jesus, D. S. V. (2017). “À deriva: economia criativa e regeneração urbana em Lisboa e no Rio de Janeiro", artigo apresentado em Encontro Nacional da Rede Observatório das Metrópoles, Natal. 
Kapp, W. (1976), "The Nature and Significance of Institutional Economics", Kyklos, 29, 2, pp. 209-232.

Lawrence, R. J.; Turgut, H.; Kellet, P. (2012). “Urban requalification, renewal, and regeneration”, in: R. J. Lawrence; H. Turgut; P. Kellet (Eds.), Requalifying the built environment: challenges and responses, Hogrefe Publishing.

Myrdal, G. (1972), Against the Stream: Critical Essays on Economics, Pantheon.

Nações Unidas. (2015), Transformando Nosso Mundo: A Agenda 2030 para o Desen-volvimento Sustentável. Disponível em: https://nacoesunidas.org/wp-content/uploads/2015/10/agenda2030-ptbr.pdf, acessado em 27 de janeiro de 2020.

Nações Unidas. (2017), A nova agenda urbana, Habitat III, Quito. Disponível em: http://habitat3.org/wp-content/uploads/NUA-English.pdf , acessado em 27 de janeiro de 2020.

Newbigin, J. (2010). A Economia Criativa: um guia introdutório, Londres: Britsh Council.

O'hara, P. A. (2009), "The principle of circular and cumula-tive causation: Myrdal, Kaldor and contemporary heterodox political economy", in: S. Berger (Org.), The foundations of non-equilibrium economics: the principle of circular and cumulative causation, London and New York: Routledge.

Projeto, Revista (2014), Levisky Arquitetos Associados e Stuchi \& Leite Projetos e Consultoria: Reabilitação da região central de Salvador. Disponível em: https://revistaprojeto.com.br/acervo/levisky-stuchi-leite-reabilitacao-centro-salvador/, acessado em 2 de dezembro de 2020.

Porter, M. E. (1985), Vantagem competitiva: criando e sustentando um desempenho superior, Rio de Janeiro: Campus.

Soja, E. (2008), Postmetropolis. Estudios críticos sobre las ciudades y las regiones, Madrid: Traficantes de Sueños.Uçkan, Ö. (2006). "Política da informação e economia do conhecimento: produtividade, emprego, crescimento e desenvolvimento" (Bilgi Politikası ve Bilgi Ekonomisi: Verimlilik, İstihdam, Büyüme ve Kalkınma), Mundo da Informação (Bilgi Dünyası), 7, 23-48.

UNCTAD. (2012). Relatório de economia criativa 2010: economia criativa uma opção de desenvolvimento, Brasília: Secretaria da Economia Criativa/MinC; São Paulo: Itaú Cultural.

UNESCO. (2011). Proposals concerning the desirability of a standard-setting instru-ment on historic urban landscapes. Disponível em: https://unesdoc.unesco.org/ark:/48223/pf0000211094, acesso em 26 de janeiro de 2020.

Vargas, H. C.; Castilho; A. L. H. de. (2009). "Intervenções em centros urbanos; objeti-vos, estratégias e resultados", in: H. C. Vargas; A. L. H. de Castilho (Orgs.), Interven-ções em centros urbanos: objetivos e resultados, 2 ed. rev. e atual, Barueri, SP: Mano-ele.

FREITAS, M. V. R. de (2018. Clusters para Consolidação Comercial de uma infraestrutura ferro-viária. Monografia de Graduação em Engenharia Civil, Departamento de Engenharia Civil e Ambiental, Universidade de Brasília . 


\section{d.)}

\section{Capítulo 8}

\section{GESTÃO DA QUALIDADE: NORMALIZAÇÃO E CERTIFICAÇÃO}

Eva Carolina Gonçalves Simões

Gabriel Borges de Lima

Giovanna de Cássia Rodrigues

Samuel Floriano Lopes de Paulo
Instituto Luterano de Ensino Superior de Itumbiara

Instituto Luterano de Ensino Superior de Itumbiara

Instituto Luterano de Ensino Superior de Itumbiara

Instituto Luterano de Ensino Superior de Itumbiara 
Resumo: Este artigo pretende abordar um estudo sobre a gestão da qualidade, assim, se aprofundará na pesquisa da normalização e certificação da qualidade. Desta forma apresenta-se como problema a seguinte questão; as empresas brasileiras têm condições e estrutura para a utilização do método de gestão de qualidade? Apresenta-se como hipótese que o sistema de gestão de qualidade é uma das alternativas para agregar valor ao produto ou serviço. Tendo como objetivos, analisar o papel das equipes multidisciplinares para o desenvolvimento e apoio deste trabalho bem como para facilitar sua aplicação em outros processos da empresa futuramente. É fundamental a utilização dos conceitos de normalização para alcançar o certificado de qualidade da empresa, estes conceitos aliados a outras técnicas de produção enxuta irão além de proporcionar a melhora na qualidade dos produtos e satisfação dos clientes. Para desenvolvimento deste artigo será feita uma pesquisa bibliográfica para levantamento sobre as técnicas e ferramentas da qualidade utilizadas nos processos de fabricação, como também em busca de artigos relacionados ao tema em sites considerados confiáveis.

Palavras chave: Qualidade. Gestão. Certificação. 


\section{INTRODUÇÃO}

Ao implantar um sistema da qualidade condizente com o ramo de negócios da organização, evidenciase um consistente ganho cultural que promove a melhoria contínua do desempenho organizacional segundo (PARIS, 2011, p. 13).

Desta forma apresenta-se como problema a seguinte questão: As empresas brasileiras têm condições e estrutura para a utilização do método de gestão de qualidade?

Em resposta a esta problemática, apresenta-se como hipótese que o sistema de gestão de qualidade é uma das alternativas para agregar valor ao produto ou serviço. Para que haja um sistema gestor qualitativo que apresente uma proporção satisfatória, são necessárias diversas propostas de treinamento, aperfeiçoamento e pesquisas que se complementam para a melhoria não somente das partes isoladas, mas do processo como um todo (DELLAMORA, 2000).

A crescente competição no mercado e as severas punições aplicadas, impulsiona as empresas a investir em qualidade e satisfação dos clientes, no qual garantirá que o mesmo se sinta seguro com a compra e consumo e atribuirá status de seriedade maior para a empresa.

Sendo que se faz necessário a normatização de todas as áreas e subáreas da instituição, inclusive a montagem de protocolos devidamente documentados e arquivados em resumos e processos de acordo com a documentação da empresa.

Reconhecer que no âmbito dos benefícios resultantes da certificação e normalização, é muito importante a reflexão sobre motivações e os benefícios das normativas implantadas. Logo, apresentase como objetivo, abordar uma análise sobre a gestão de qualidade, e o papel das equipes multidisciplinares para o desenvolvimento e apoio deste trabalho, bem como para facilitar sua aplicação em outros processos da empresa futuramente.

Tendo etapas como o estudo do método para identificação dos pontos críticos e diminuição de falhas no processo de fabricação desde a recepção de matéria prima até produto final, utilizando-se conceitos preventivos de HACCP (Hazard Analysis and Cutical Control Point System), ou seja controle de todas as etapas de preparação, iniciando pela matéria prima até produto acabado, seguindo para o processo, ambiente, pessoas e estrutura para diminuir ou até eliminar falhas no processo, análise de riscos e pontos críticos de controle.

Análise dos os projetos e redução de barreiras técnicas e comerciais: Analisar a padronização para a garantia e o atendimento às regulamentações internacionais. Na prática de acordo com Dellamora 
(2000), a normalização está presente na fabricação dos produtos, na transferência de tecnologia, na melhoria da qualidade de vida através de normas relativas à saúde, a segurança e a preservação do meio ambiente.

Tem-se como justificativa que como futuros engenheiros de produção, a aplicação de SGQ (sistema de gestão de qualidade) e a aplicação de novos conceitos de normalização e certificação possibilita uma diminuição no gasto para a empresa com produtos retidos por não conformidades em questão de qualidade do produto, o que não agrega valor ao meio produtivo e só aumenta os gastos. A satisfação dos clientes e consumidores, como também dos gestores e colaboradores, confiabilidade, fidelidade, garantia do produto e competitividade no mercado.

É fundamental a utilização dos conceitos de normalização para alcançar o certificado de qualidade da empresa. Estes conceitos aliados a outras técnicas de produção enxuta irão além de proporcionar melhora na qualidade dos produtos e satisfação dos clientes, também estarão contribuindo para que a empresa chega ao ápice de mercado com melhoria em suas técnicas produtivas.

De acordo com Dellamoura (2000) que argumenta a importância de desenvolver uma abordagem de processos e identificação das ferramentas adequadas para o controle e melhoria, salienta-se ainda que toda organização deva se preocupar em prestar o melhor produto possível aos clientes entender a importância da redução e eliminação de perdas por qualidade é fundamental para que os recursos da organização sejam aplicados naquilo que realmente gera resultados.

Para desenvolvimento deste artigo será abordando uma pesquisa bibliográfica para levantamento sobre as técnicas e ferramentas da qualidade utilizadas no trabalho e o processo de fabricação, elaborada por meio dos livros contidos na biblioteca Martin Lutero, do ILES/ULBRA de Itumbiara, como também em busca de artigos em sites considerados confiáveis.

Nesta direção, os recursos utilizados serão buscas na internet para a coleta de dados. Estabeleceu que serão 10 artigos que fornecerão indicações sobre o tema estudado, estabelecendo uma linha de tempo sobre o desenvolvimento do objetivo de pesquisa abordado. Os dados serão analisados da forma qualitativa, explicando as melhorias continuas na gestão de qualidade tanto quanto possível. 


\section{DESENVOLVIMENTO}

A noção de qualidade não é algo recente, pois desde cedo os consumidores manifestaram o seu interesse pela qualidade de produtos ou serviços, inspecionando e controlando os mesmos. Está, assim, relacionada com o grau de satisfação de requisitos dados por um conjunto de características intrínsecas.

A certificação enquanto ferramenta de gestão é relevante para a inovação e desenvolvimento sustentável de uma organização, e é um resultado de uma boa gestão, um fator de motivação e de reconhecimento do desempenho da empresall.

Com a evolução industrial e diante a tantas fraudes, enganações, propinas e corrupções o mercado assumiram um papel ativo com leis a seu favor. Desta forma, a competição entre as mesmas criou uma disputa no mercado que busca a perfeição e nada mais que isso.

O crescimento econômico das empresas tem acontecido linearmente à medida que o trabalho humano vai sendo substituído gradualmente pelo uso de máquinas, a força e energia do homem são trocadas pela agilidade e perfeição produtiva das máquinas desde a revolução industrial. Porém era necessária sempre a atenção contínua do ser humano, vinculada a sua capacidade de identificação e correção dos erros, uma vez que as mesmas apresentam baixa confiabilidade. (FURTINI, 2006).

A abordagem do sistema de gestão da qualidade incentiva as organizações a analisar os requisitos dos clientes, a definir os processos que contribuem para a realização de um produto aceitável pelo cliente e a manter estes processos sob controlo. Um sistema de gestão da qualidade permite criar o enquadramento certo para a melhoria contínua, de modo a incrementar a probabilidade de aumentar a satisfação dos clientes e das outras partes interessadas. Um sistema de gestão da qualidade transmite confiança à organização e aos seus clientes quanto à sua capacidade para fornecer produtos que cumpram de forma consistente os respetivos requisitos (IPQ, 2005).

Surgiu assim, a ideia de criar um "selo" que garantisse que a empresa esteja cumprindo com as normas de qualidade vigentes em lei e no código de defesa do consumidor. Essa garantia contribuiu para os clientes ficassem seguros com a compra e consumo que atribui seriedade maior.

Sendo assim, fez necessário a criação de diversos órgãos para normalizar e criar regras para a fábrica pudesse manter-se em funcionamento. Estes órgãos ficam responsáveis pela criação de padrões na produção que trouxeram maior segurança, saúde e qualidade do produto, bem como a aplicação de punições às companhias que não cumprisse de acordo como foi instituído. 
A análise de qualidade e/ou segurança do produto por análise de produto acabado é relativa, de alcance limitado. Por mais rigoroso que sejam os planos de amostragem, a caracterização de $100 \%$ das unidades do lote ou do conjunto de lotes produzidos dificilmente é alcançado em condições práticas. Demais companhias, de diversos setores, notaram a eficiência que a produção enxuta proporciona às grandes no mercado. Assim, foram criadas centenas de teses, artigos e ferramentas que propõem a melhoria da qualidade empresarial como forma de alcançar mercados maiores e exigentes.

\subsection{APLICAÇÃO DA GESTÃO DA QUALIDADE}

Para que haja um sistema gestor qualitativo satisfatório, são necessárias diversas propostas de treinamentos, análises, aperfeiçoamentos e pesquisas que complementarão para melhoria.

Em primeiro lugar, deve-se criar um sistema de informações que agregará todos os dados colhidos durante a análise de sus processos. Esse sistema deve colher em tempo real as informações que permitam conhecer as variáveis internas e externas que facilitem o planejamento, organização, coordenação, avaliação e controle de programas e serviços de promoção na melhoria dos processos existentes.

Segundamente, é fundamental a normatização de todas as áreas e subáreas da instituição, inclusive com montagem de protocolos devidamente documentados e arquivados em resumos e processos implementados de acordo com documentação da empresa. Desta maneira, torna-se mais fácil a compilação de materiais para fins jurídicos.

É necessário ser o mais realista possível com os resultados que forem surgindo. Mesmo que não sejam os esperados pela gerência, é necessário ter um conhecimento geral do fluxo de melhorias que estão sendo aplicadas com o intuito de programar as próximas etapas e até mesmo corrigir as que estão apresentando falhas.

Na implantação do sistema de gestão, como anteriormente dito, é fundamental a importância do comprometimento da alta administração. Uma das tarefas de destaque da administração está em conduzir a interdependência dos processos que a formam.

\subsection{PRINCÍPIOS DA GESTÃO DA QUALIDADE}


Existem oito princípios de gestão da qualidade, que podem ser adotados pela gestão de topo de uma organização para que esta seja levada a alcançar um melhor desempenho. A baixo iremos apresentar alguns destes princípios.

Princípio Explicação:

- Focalização no cliente - as organizações dependem dos seus clientes e, consequentemente, convém que compreendam as suas necessidades, atuais e futuras, satisfaçam os seus requisitos e se esforcem por exceder as suas expectativas.

- Focalização no cliente significa que a organização dedica a sua energia na procura da satisfação dos seus clientes e compreende que é dessa satisfação que advém o lucro.

- Liderança - os líderes estabelecem a finalidade e a orientação da organização. Convém que criem e mantenham um ambiente interno que permita o pleno envolvimento das pessoas a fim de se atingirem os objetivos da organização.

- A liderança consiste em providenciar modelos comportamentais consistentes com os valores da organização - comportamentos que irão permitir alcançar os objetivos da organização. 0 ambiente interno inclui o clima, o estilo de gestão, os valores partilhados, a confiança, a motivação e o apoio.

- Envolvimento das pessoas - as pessoas, em todos os níveis, são a essência de uma organização e o seu pleno envolvimento permite que as suas aptidões sejam utilizadas em benefício da organização.

Envolver as pessoas significa partilhar conhecimento, encorajar e reconhecer a sua contribuição, utilizar a sua experiência e trabalho com integridade.

- Abordagem por processos - um resultado desejado é atingido de forma mais eficiente quando as atividades e os recursos associados são geridos como um processo.

Os processos são dinâmicos, fazem com que as coisas aconteçam. Os procedimentos são estáticos ajudam as pessoas a cumprir uma tarefa.

Abordagem da gestão como um sistema, ajuda a identificar, compreender e gerir processos interrelacionados, o sistema contribui para que a organização atinja os seus objetivos com eficácia e eficiência. 


\subsection{IMPLEMENTAÇÃO E CERTIFICAÇÃO}

É interessante saber diferenciar normalização de normatização. Normalizar é submeter algo a normas, padronizar, enquanto normatizar é estabelecer normas para alguma coisa, ação ou processo. É indispensável o estabelecimento de normas para que se garanta o padrão de qualidade aos diversos produtos e processos, entretanto isso não acontecia em tempos remotos, onde as pessoas passaram muitas dificuldades por não ter um padrão adequado ao que estavam consumindo ou produzindo. Com certeza, isso gerava um desperdício por parte do produtor e uma insegurança por parte do consumidor.

Os objetivos das normas técnicas são: a simplificação; a intercambialidade; a comunicação; a adoção racional de símbolos e códigos; a economia; a segurança; saúde e proteção da vida; o impedimento de barreira no comércio; proteção do interesse do consumidor; interesse da comunidade. (PARIS, 2011).

Implementação e certificação são duas etapas diferentes do sistema de gestão da qualidade que buscam o mesmo objetivo: a obtenção da qualidade total.

Mesmo nos tempos de hoje, em que a confiabilidade das máquinas é muito maior e as mesmas já são capazes de identificar e corrigir totalmente os erros na produção, ainda existe a fiscalização do ser humano por questões habituais da sociedade.

As empresas buscam reduzir os custos, eliminar desperdícios, controlar a fabricação e estocagem e garantir os padrões de qualidade total, com foco principal: a satisfação do cliente. Com o levantamento de campo através do uso da pesquisa descritiva foi observado que para realizar a aplicação do evento Kaizen identificou-se a área que apresentava gargalos para a aplicação de possíveis melhorias.

Ao implementar a ISSO 9001, a empresa mostra ao colaborador que pensa no futuro, que não quer ficar estagnada no mercado, e acredita que melhorias devem ser realizadas e sugeridas continuamente. Assim, é muito provável que o profissional se sinta motivado a trabalhar melhor, rever conceitos, e abraçar as mudanças que a certificação acarreta.

Com a ISSO 9001, a indústria será capaz de monitorar os elementos básicos necessários para se criar valor para o cliente: qualidade, relacionamento, desempenho, preço e benefícios e ainda terá critérios objetivos para monitor a sua satisfação. Clientes, mesmo que inconscientemente, percebem essas melhorias. E ter a imagem da empresa em alta é um excelente investimento. 
Introdução à Normalização e Certificação se inicia a partir da apresentação inicial do módulo, passando por um tratamento histórico posicionando os aspectos da normalização e certificação ao longo do tempo, desde as primeiras formas de normalização até as Certificações Internacionais impostas pela globalização dos mercados nos dias de hoje. Além disso, neste bloco também são trabalhados alguns conceitos iniciais, com vistas a uma melhor compreensão ao longo do curso. (PARIS, p.03, 2011).

No âmbito dos benefícios resultantes da certificação, é inevitável a reflexão sobre as motivações que levaram as empresas a certificarem-se. De uma forma simples, quando as empresas procuram a certificação, com base em motivações internas, vão alcançar benefícios internos, isto é, benefícios relacionados com a melhoria interna da organização.

No segundo bloco, Normalização e seus elementos de estruturação, são apresentados: a função e os principais objetivos da normalização dentro de uma organização produtiva, bem como, os maiores impactos da normalização para a organização. Em seguida são listadas algumas normas que compõe a série ISO. A partir deste ponto, são trabalhados os Elementos de Sustentação da Normalização, compostos por: quatro atores inter-relacionados (Cliente, fornecedor, líder e colaborador) representando a Gestão de Relacionamento, e a tríade que orbita este relacionamento (Informações, Melhoria Contínua e Processos). (PARIS, p. 03, 2011).

Quando as empresas procuram a certificação devido a motivações externas vão alcançar benefícios externos, ou seja, benefícios relacionados com a satisfação dos clientes, também estarão contribuindo para que a empresa chegue ao ápice de mercado com melhoria em suas técnicas produtivas.

\subsection{EXECUÇÃO DO HACCP}

Em algumas etapas do processo conforme necessário, poderão ser utilizadas ferramentas da qualidade. Essas ferramentas irão complementar as análises e fornecer subsídios para as melhorias. 0 HACCP (Hazard Analysis and Cutical Control Point System) é um sistema baseado em conceitos preventivos, controle de todas as etapas. O sistema envolve estudo dos ingredientes, produto, condições do processo, manuseio, estocagem, embalagem, distribuição, público alvo e modo de consumo. O sistema HACCP, poderosa ferramenta de gestão para conseguir obter um programa de controle de qualidade.

Apesar do sistema de HACCP ser fundamentalmente implantado para garantir a segurança microbiológica dos alimentos, “(...) seu conceito pode ser estendido de forma mais abrangente, com objetivos de também garantir a qualidade do produto" (DELLAMORA, p.11, 2000).

A redução e/ou eliminação de reclamações de clientes, a melhoria nos índices de retrabalho, reforçando ganhos nos índices de produtividade, são consequências de aplicações do sistema. 0 
sistema APPCC tem como objetivo identificar, avaliar e controlar os perigos para a saúde do consumidor e caracterizar os pontos e controles considerados críticos para assegurar a inocuidade dos alimentos, sendo também uma boa alternativa de melhoria em todo o processo.

\section{CONCLUSÃO}

Atualmente existem diversos sistemas completos, que seguem todas as normalizações da gestão da qualidade e que possuem etapas que devem ser seguidas criteriosamente para alcançar com eficácia, resultados bem sucedidos, em qualquer projeto de melhoria contínua aplicado em uma organização.

Conclui-se, então, com o artigo apresentado que a aplicação da gestão da qualidade e o recebimento positivo de suas certificações, agrega valor a empresa em relação a satisfação do cliente, vantagem no mercado competitivo e internamente, quando se trata de economia de custos, redução de refugos e aumento da produtividade. 


\section{REFERÊNCIAS}

BITTAR, O. J. N. V. Gestão de processos e certificação para qualidade em saúde. Revista da Associação Médica Brasileira, São Paulo, v. 46, n. 1, p. 2-7, mar. 2000. Disponível em:

<http://www.scielo.br/scielo.php?script=sci_arttext\&pid=s0104-42302000000100011>. Acesso em: 11 mar. 2017.

DELLAMORA, Marlise D. GARCIA. Uso integrado das técnicas de HACCP, CEP E FEMEA. Universidade Federal do Rio Grande do Sul, Porto Alegre, dez. 2000.

Disponível

em:<http://www.producao.ufrgs.br/arquivos/publicacoes/Marlise\%20Dellamore\%20Garcia.PDF.>

DEPEXE, Marcelo D.; PALADINI, Edson P. Benefícios da implantação e certificação de sistemas de gestão da qualidade em empresas construtoras. Revista Gestão Industrial, Ponta Grossa, v. 04, n. 2, p. 3-16, jun. 2008. Disponível em:

<https://www.researchgate.net/profile/marcelo_depexe/publication/251048422_beneficios_da_im plantacao_e_certificacao_de_sistemas_de_gestao_da_qualidade_em_empresas_construtoras/links/ Odeec53a58b7176a88000000.pdf>.Acesso em: 09 mar. 2017.

DIAS, Sabrina Da Silva; BARBOSA, Vanessa Camarinha; COSTA, Stella Regina Reis Da. Utilização do APPCC como ferramenta da qualidade em indústrias de alimentos. Revista ufrrj, Rio de janeiro, v. 20, n. 1, p. 2-13, ago. 2011.

FURTINI, L.G.; ABREU, L.R.; Utilização de APPCC na Indústria de Alimentos. Ciência e Agrotecnologia. Lavras, v.30. n.2, p. 358-363, Mar/abr.2006.

GRAEL, Paulo Fernando Fuzer. Etal. Sistemas certificáveis de gestão ambiental e da qualidade: práticas para integração em empresas do setor moveleiro. Revista Production vol.20 no.1 São Paulo Jan./Mar. 2010. Disponível em: <http://dx.doi.org/10.1590/S0103-65132010005000017>

IPQ (2005). Norma Portuguesa EN ISO 9000:2005 - Sistemas de Gestão da Qualidade, Fundamentos e Vocabulário. Caparica, Instituto Português da Qualidade.

MONTALLI, Katia Maria Lemos; CAMPELLO, Bernardete dos Santos. Revista Ciências da Informação, vol. 26 no. 3 Brasília Set./Dez. 1997. Disponível em: <http://dx.doi.org/10.1590/S010019651997000300014>

OLIVEIRA, José Augusto. Etal. Um estudo sobre a utilização de sistemas, programas e ferramentas da qualidade em empresas do interior de São Paulo. Revista Production, vol.21 no.4 São Paulo 2011 Disponível em: <http://dx.doi.org/10.1590/S0103-65132011005000044>

PARIS, Wanderson S. Normalização e certificação da qualidade. Cronos Quality Consultoria e Treinamentos, São Paulo, v. 1, n. 1, p. 15-27, out. 2011. Disponível em:

<http://cronosquality.com/aulas/ncq.pdf>. Acesso em: 03mar. 2017. 
PORTUGAL, J. A. B. et al. Segurança alimentar na cadeia de leite. Juiz de Fora: EPAMIG/CT/ILCT, Embrapa Gado de Leite, 2002. 226p.

SANTOS, F. F. et al. Análise da gestão da qualidade em um laticínio: um estudo de caso. Abrepo, Salvador, v. 12, n. 7, p. 2-13, out 2013. Disponível em:

http://www.abepro.org.br/biblioteca/enegep2013_tn_stp_178_019_22644.pdf. Acesso em: 08 mar. 2017.

SCALCO, A.R.; TOLEDO, J.C.; A Gestão da Qualidade em Laticínios do Estado de São Paulo: Situação Atual e Recomendações. Disponível em: < http:// www.sebraepb.com.br >. Acesso em: 24 jul. de 2010.

SHINGO, Shingo. O sistema Toyota de produção: do ponto de vista da engenharia de produção. Porto Alegre: Bookman, 1996.

VILELA, D., et al., Agronegócio de leite e derivados: um programa nacional em C\&T, In :Agronegócio Brasileiro: Ciência, Tecnologia e Competitividade, Brasília: CNPq, 1998, p.259-275. 


\section{Capítulo 9}

\section{d.)}

\section{ANÁLISE ECONÔMICO-FINANCEIRA DA SUBSTITUIÇÃO DE UM APARELHO DE AUTOMAÇÃO EM HEMATOLOGIA EM UM LABORATÓRIO DE ANÁLISES CLÍNICAS}

Bianca Michels Chaves

Denis Rasquin Rabenschlag
Universidade Federal de Santa Maria

Universidade Federal de Santa Maria 
Resumo: A necessidade de análises de custos, investimentos e riscos têm se mostrado determinantes para a sobrevivência e sucesso de organizações no contexto atual. O ramo das ciências da saúde em geral, incluindo as análises clínicas, não é exceção disso. Dentro desse âmbito, o referente artigo propôs uma análise econômico-financeira de uma substituição de equipamento em um laboratório de análises clínicas localizado na região oeste do Rio Grande do Sul, com a utilização de métodos ligados à Engenharia Econômica, sendo esses fluxo de caixa, Valor Anual Uniforme Equivalente (VAUE) e payback descontado. A pesquisa caracterizou-se como estudo de caso de cunho exploratório, que a partir dos métodos empregados, permitiu concluir que a substituição não-idêntica do equipamento em questão não seria a melhor opção, bem como possibilitou determinar a vida econômica dos aparelhos "defensor" e "desafiante" e o período payback do investimento. Assim, pôde-se comprovar a importância de análises de investimento, especialmente análises de substituição de equipamentos, no contexto de decisões de capital.

Palavras-chave: Engenharia econômica, Análise econômico-financeira, Substituição de equipamentos 


\section{INTRODUÇÃO}

Hodiernamente, cada vez mais o meio empresarial tem se tornado competitivo, devido ao avanço das tecnologias e seu uso intensificado. O ramo das ciências da saúde em geral, incluindo as análises clínicas, não é exceção; os empresários desse setor precisam estar atentos a métodos de gestão organizacional e estratégica para que consigam manter-se competitivos no mercado.

Mugnol \& Ferraz (2006) afirmam que essa modernização desencadeada pela evolução da ciência médica, que traz quase sempre consigo um maior custo às instituições de saúde, unida a pressões do mercado e ao estresse das oscilações financeiras, tem ocasionado a busca de um aprendizado a curto prazo dos fundamentos da gestão de custos. A necessidade de análises de investimento e risco também têm se mostrado determinantes para a sobrevivência e sucesso de organizações no contexto atual.

O presente estudo visa comprovar a importância da realização de análises de investimento dentro dessa conjuntura, em que cada vez mais se busca aliar a tecnologia à realização de diagnósticos precisos e com alto nível de confiabilidade, porém, sem prejuízos financeiros. Nesse sentido, o enfoque será a substituição de equipamentos dentro de um laboratório de análises clínicas localizado no oeste do Rio Grande do Sul, havendo a avaliação econômico-financeira de um investimento já realizado pela organização.

Esta terá como objetivo verificar se o investimento realizado trouxe ou não o retorno esperado e, caso não tenha trazido, descrever qual seria a melhor alternativa a ser escolhida. Será ressaltada a importância da aplicação de conceitos relacionados à Engenharia Econômica - como payback, fluxo de caixa e Valor Anual Uniforme Equivalente (VAUE) - para a tomada de decisões de capital.

\section{REFERENCIAL TEÓRICO}

Para a análise de substituição de equipamento proposta, foram utilizados métodos como fluxo de caixa, VAUE e payback descontado, que possuem vasta aplicação no campo da Engenharia Econômica.

\subsection{ANÁLISE DE INVESTIMENTO}

Para Motta \& Calôba (2002), a análise de investimentos tem como objetivo obter, por meio de técnicas avançadas e com a utilização de conceitos e métodos que abrangem Estatística, Matemática Financeira e Informática, "uma solução eficiente para uma decisão compensadora". 
De acordo com Souza \& Clemente (2012), decisões de capital em uma empresa estão ligadas diretamente ao nível estratégico desta, uma vez que, ao mesmo tempo em que têm potencial para consolidar uma trajetória de expansão, podem comprometer a própria sobrevivência da organização. A partir disso, os autores afirmam que, mesmo que não haja maneira de eliminar os riscos de que os resultados previstos para um projeto não se concretizem, é necessário que as decisões de capital que o envolvem baseiem-se em previsões e cálculos de todas as variáveis relevantes, para que haja uma minimização desses riscos.

\subsection{ANÁLISE DE SUBSTITUIÇÃO DE EQUIPAMENTOS}

No campo da Engenharia Econômica, uma das aplicações mais significativas da análise de investimentos é a análise de substituição de equipamentos. Esta se refere a toda a variedade de ativos fixos (bens de capital) e não apenas ao que é entendido como "equipamento".

A análise de substituição de equipamentos é quase sempre complexa, uma vez que além de levar em consideração fatores econômico-financeiros, deve ser complementada por outros fatores, denominados imponderáveis. Um dos aspectos que devem ser considerados é a experiência de engenheiros, administradores e outros profissionais diretamente ligados às decisões de capital da empresa, capaz de reduzir os riscos que envolvem determinado investimento (SOUZA; CLEMENTE, 2012). Os autores afirmam que também é de extrema relevância que inovações tecnológicas sejam consideradas para a tomada de decisão.

Segundo Silva \& Santiago (2006), além de indicar qual é a melhor alternativa de investimento, essa análise também tem por objetivo apontar em que momento o equipamento novo deve substituir o antigo, se essa for a alternativa mais indicada. Um exemplo da relevância da determinação desse momento dá-se no fato de que a substituição é essencial nos casos em que o equipamento apresenta falhas mecânicas que, mesmo passíveis de conserto, demonstram um agravamento progressivo, exigindo tempos de reparo e custos cada vez maiores (MOTTA; CALÔBA, 2002).

\subsection{MÉTODO DO VALOR ANUAL UNIFORME EQUIVALENTE (VAUE)}

Kassai et al. (2007) define o VAUE (também conhecido como Valor Presente Líquido anualizado - VPLa) como um método que objetiva comparar o valor médio periódico dos fluxos de caixa positivos com o dos negativos, demonstrando um resultado equivalente em bases periódicas. 
Este é uma variação do Método do Valor Presente Líquido (VPL); enquanto o VPL concentra todos os valores do fluxo de caixa na data zero, o VAUE transforma-os em uma série anual uniforme (MOTTA; CALÔBA, 2002). De acordo com Silva \& Santiago (2006 apud Lapponi, 1996), o método do VAUE determina que dentre duas alternativas, a que tiver o maior saldo positivo é a melhor.

O método do VAUE é utilizado em casos de análise de substituição de equipamentos, como mencionado nos cinco princípios fundamentais por Motta \& Calôba (2002). No caso de políticas de substituição de um equipamento por outro de tipo diferente, os autores generalizam que, se VAUE(t $\left.t_{1}\right)_{\text {। }}$ $>\operatorname{VAUE}\left(t_{2}\right)_{11}$, em que $t_{1}$ pode ser diferente de $t_{2}$, representando os prazos de maiores valores anuais equivalentes, é viável, economicamente, a substituição do equipamento I (defensor) pelo II (desafiante). Já no caso de políticas de substituição de equipamentos por similares (substituição idêntica), o VAUE é diretamente relacionado ao conceito de vida econômica.

\subsection{FLUXO DE CAIXA}

O fluxo de caixa pode ser definido como um instrumento de controle de entradas e de saídas do dinheiro. Dalbello (1999 apud Assaf Neto \& Silva, 1995) define-o como um instrumento que descreve as movimentações financeiras de uma empresa em determinado período de tempo, sendo que sua utilização visa preservar uma liquidez imediata essencial à manutenção das atividades da organização "A representatividade dos resultados de um investimento é bastante dependente do rigor e confiabilidade com que os fluxos de caixa estão estimados" (KASSAl et al., 2007). Os autores afirmam que apenas devem ser levados em consideração no fluxo valores que efetivamente representem entradas ou saídas de caixa.

\subsection{PERÍODO PAYBACK}

O payback é o período de tempo necessário para que ocorra o retorno de determinado investimento. Sua versão mais conhecida do payback é a original, que de acordo com Kassai et al. (2007), é obtida por meio da soma dos fluxos de caixas negativos com os positivos, até que se obtenha zero como resultado. Os autores descrevem a versão original como "mais uma medida de risco do que propriamente de retorno de investimento", já que esta não considera o valor do dinheiro no tempo.

Outra versão do período payback, esta mais sofisticada do que a primeira, é a chamada payback descontado, que é feita com o custo de oportunidade do capital, de acordo com Brito (2011). Sua abordagem é próxima à versão original, mas leva em consideração valores descontados, ou seja, se 
baseia em valores trazidos em moeda do período zero pela taxa mínima de atratividade do projeto, a partir do cálculo do VPL (KASSAl et al., 2007).

\section{METODOLOGIA}

A presente pesquisa é caracterizada como estudo de caso, de caráter exploratório. Guilhoto (2002 apud Godoy, 1995) descreve que um estudo de caso visa submeter uma unidade a uma análise profunda e minuciosa, tendo como objetivo examinar detalhadamente um ambiente, um indivíduo ou uma situação em particular, por meio de técnicas como a observação e a entrevista. Yin (2015) afirma que o método "começa com uma revisão minuciosa da literatura e com a proposição cuidadosa e atenda das questões ou objetivos da pesquisa".

Inicialmente, realizou-se uma revisão bibliográfica a respeito de métodos relacionados à Engenharia Econômica que pudessem ser aplicados de acordo com os objetivos estabelecidos para a pesquisa. A coleta de dados foi feita por meio de uma visita ao laboratório de análises clínicas em questão a fim de observar o quadro da situação do equipamento, bem como de entrevista semiestruturada com o farmacêutico-bioquímico responsável pela gestão da empresa. Também foram analisados os contratos de compra dos equipamentos em questão, junto a seus respectivos manuais para obtenção de especificações técnicas, assim como dados fornecidos pelo escritório de contabilidade que presta assessoria ao laboratório.

Após, houve a aplicação de métodos relacionados ao campo da Engenharia Econômica - fluxo de caixa, VAUE e período payback - cujos cálculos e planilhas foram elaborados com a utilização do software Microsoft Excel. O estudo encontrou limitações em relação à capacidade de prever receitas e custos para o período de tempo futuro determinado. Assim, para a obtenção desses valores, foram estimadas margens de variação dos diversos fatores envolvidos, de forma a proporcionar maior veracidade aos cálculos e uma previsão mais próxima da realidade.

\section{CARACTERIZAÇÃO DO PROBLEMA}

A empresa em questão é um laboratório que atua há 40 anos no ramo de análises clínicas em Uruguaiana, cidade da região oeste do Rio Grande do Sul. Possui um faturamento bruto anual de R\$ 420.000,00, atendendo em média a 800 pacientes ao mês. São realizados no laboratório exames nas áreas de hematologia, bioquímica, imunologia, parasitologia, microbiologia, urinálise, marcadores tumorais, entre outras. 
A área de hematologia tem destaque dentro da empresa, sendo responsável por gerar aproximadamente $20 \%$ do faturamento bruto anual. As análises hematológicas são realizadas por meio de um aparelho de automação em hematologia, sendo que entre 1990 e 2016 o equipamento utilizado para desempenhar essa função era do modelo Beckman Coulter T890. Em 2016, este foi substituído por outro, que utiliza tecnologia mais avançada e apresenta maior confiabilidade, do modelo Sysmex XS800i.

O presente estudo tem como objetivo avaliar se essa substituição de equipamento trouxe ou não benefício financeiro ao laboratório e, caso não tenha trazido, indicar qual teria sido a melhor alternativa. Também visa determinar qual a melhor decisão a ser tomada a respeito do equipamento de agora em diante, bem como quando o investimento no equipamento novo terá retorno.

\section{COLETA E ANÁLISE DE DADOS}

Para a aplicação dos métodos relacionados à Engenharia Econômica, houve a coleta de dados relacionados à política de compra, manutenção e utilização dos aparelhos de automação em hematologia de um laboratório de análises clínicas do oeste do Rio Grande do Sul.

\subsection{CUSTO DO INVESTIMENTO}

O investimento inicial para aquisição do equipamento antigo (Beckman Coulter T890), à época em que foi adquirido, foi de R\$25.000,00. Já o aparelho novo (Sysmex XS800i), adquirido em 2016, requereu um investimento de $\mathrm{R} \$ 58.360,00$, em que $\mathrm{R} \$ \mathbf{1 0 . 0 0 0 , 0 0}$ foram abatidos com a entrega do equipamento antigo.

\subsection{CUSTOS OPERACIONAIS}

Os custos operacionais de cada equipamento foram divididos entre custos diretos, que estão relacionados aos fatores diretos de produção, e custos indiretos, que normalmente não variam proporcionalmente à produção.

\subsubsection{CUSTOS OPERACIONAIS DIRETOS}

Foram levantados custos atuais em relação a matérias-primas, embalagens, materiais auxiliares e mão-de-obra direta necessárias ao funcionamento de cada equipamento. Estes estão especificados na Tabela 1, de acordo com suas classificações, e foram calculados com base em um mês com 22 dias de 
trabalho (excluindo finais de semana) e uma média de 500 hemogramas mensais - aproximadamente 23 por dia.

Tabela 1 - Custos operacionais diretos mensais por aparelho

\begin{tabular}{llll}
\hline Tipo de custo & Descrição do custo & Aparelho antigo & Aparelho novo \\
\hline $\begin{array}{l}\text { Matérias- } \\
\text { primas }\end{array}$ & Reagentes & $\mathrm{R} \$ 350,00$ & $\mathrm{R} \$ 1.085,00$ \\
Embalagens & Envelopes plásticos & $\mathrm{R} \$ 40,00$ & $\mathrm{R} \$ 40,00$ \\
$\begin{array}{l}\text { Materiais } \\
\text { auxiliares }\end{array}$ & Impressões & $\mathrm{R} \$ 25,00$ & $\mathrm{R} \$ 40,00$ \\
& Seringas & $\mathrm{R} \$ 30,00$ & $\mathrm{R} \$ 30,00$ \\
& $\begin{array}{l}\text { Hipoclorito de sódio } \\
\text { (limpeza) }\end{array}$ & $\mathrm{R} \$ 2,50$ & $\mathrm{R} \$ 2,50$ \\
& Agulhas & $\mathrm{R} \$ 55,00$ & $\mathrm{R} \$ 55,00$ \\
Mão-de-obra & Salário farmacêutico- & $\mathrm{R} \$ 1.285,02$ & $\mathrm{R} \$ 428,34$ \\
direta & bioquímico & & \\
\hline Total & & $\mathbf{R} \$ \mathbf{1 . 7 8 7 , 5 2}$ & $\mathbf{R} \$ \mathbf{1 . 6 8 0 , 8 4}$ \\
\hline
\end{tabular}

Fonte: Autoria Própria

O custo da mão-de-obra direta foi fundamentado no salário base de um farmacêutico-bioquímico estabelecido pelo Sindifars (2016) para meio turno de trabalho (22h semanais), que é de $R \$ 1.713,00$, levando-se em consideração que para o aparelho antigo são requeridas três horas de mão-de-obra diárias, e para o aparelho novo, apenas uma.

A partir disso, pode-se concluir que os custos operacionais diretos anuais do aparelho antigo e do aparelho novo são de $\mathrm{R} \$ 21.450,24$ e de $\mathrm{R} \$ 20.170,08$, respectivamente.

\subsubsection{CUSTOS OPERACIONAIS INDIRETOS}

Os custos indiretos de cada aparelho estão vinculados à manutenção corretiva e preventiva. O Coulter T890 requisita manutenção preventiva anual e manutenção corretiva a cada três anos, em média, devido ao desgaste acarretado ao longo dos anos de funcionamento. O valor médio atual da manutenção corretiva para esse aparelho é de $\mathrm{R} \$ 1.500,00$.

O XS800i também necessita de manutenção preventiva anual; no entanto, devido ao pouco tempo de uso até o presente, estima-se que requeira manutenção corretiva a cada seis anos. $O$ valor médio atual de sua manutenção corretiva é mais elevado, ficando em torno de $\mathrm{R} \$ 3.000,00$. Esses custos estão 
descritos na Tabela 2, em que é feita uma média anual, e abrangem mão-de-obra indireta, peças e reposição de materiais.

Tabela 2 - Custos operacionais indiretos anuais por aparelho

\begin{tabular}{lccc}
\hline Tipo de custo & Descrição do custo & Aparelho antigo & Aparelho novo \\
\hline Manutenção & Preventiva & $\mathrm{R} \$ 1.500,00$ & $\mathrm{R} \$ 3.000,00$ \\
& Corretiva & $\mathrm{R} \$ 500,00$ & $\mathrm{R} \$ 500,00$ \\
\hline Total & & $\mathbf{R} \$ \mathbf{2 . 0 0 0 , 0 0}$ & $\mathbf{R} \$ \mathbf{3 . 5 0 0 , 0 0}$ \\
\hline
\end{tabular}

Fonte: Autoria Própria

\subsection{OUTRAS DESPESAS E DESEMBOLSOS}

Além dos custos operacionais, os equipamentos estão sujeitos a outras despesas e desembolsos, ligados à depreciação contábil e ao imposto de renda. Foi considerada uma taxa de depreciação de 10\% ao ano em um período de 10 anos, de acordo com a tabela atual de quotas de depreciação de bens do Ativo Imobilizado, bem como a alíquota de 10,85\% para o imposto de renda (de acordo com a tributação do Simples Nacional e com as especificações da empresa, obtidas junto ao escritório de contabilidade que lhe presta assessoria).

O Beckman Coulter T890, que já tem mais de 10 anos de utilização, não pode mais ser depreciado. Já o Sysmex XS800i será depreciado totalmente nos próximos 10 anos de uso, em um valor de R\$ $5.836,00$ ao ano.

\subsection{RECEITAS}

No laboratório de análises clínicas analisado, são realizados em média 500 hemogramas por mês. Levando-se em consideração que o preço médio estabelecido para o hemograma é de $R \$ 12,50$ e que todos esses exames são feitos no aparelho de automação em hematologia em uso no laboratório, este é responsável por gerar uma receita bruta mensal de $R \$ 6.250,00$, ou $R \$ 75.000,00$ anuais.

\section{RESULTADOS}

A partir dos dados levantados, foi possível elaborar a planilha de fluxo de caixa para os dois equipamentos. Estima-se que o Beckman Coulter T890 ainda tivesse vida útil de 5 anos, por isso, o fluxo de caixa estimado para o equipamento foi elaborado para esse período. Já o fluxo estimado para o Sysmex XS800i foi estimado para um período de 10 anos. 
Para ambos os aparelhos, foi feita uma estimativa de redução gradual das receitas obtidas, bem como de aumento gradual dos custos diretos e indiretos. A Tabela 3 apresenta a porcentagem estimada de variação anual para cada um desses itens, de acordo com o equipamento. Essas estimativas tiveram base nas informações fornecidas pela entrevista com o responsável pelo laboratório.

Tabela 3 - Variação anual estimada de receitas e custos por equipamento

\begin{tabular}{lcc}
\hline Aspecto considerado & Aparelho antigo & Aparelho novo \\
\hline Receitas & $-5,0 \%$ & $-2,5 \%$ \\
Custos diretos & $+5,0 \%$ & $+5,0 \%$ \\
Custos indiretos & $+10 \%$ & $+5,0 \%$ \\
\hline
\end{tabular}

Fonte: Autoria Própria

O decréscimo nas receitas foi previsto devido ao fato de que, quanto maior o tempo de uso do equipamento, maior o seu desgaste, exigindo maior tempo de manutenção e, consequentemente, ocasionando menor tempo de produção. Foi estimado que esse decréscimo seria mais acentuado no caso do aparelho antigo, uma vez que este já está em funcionamento há vários anos e apresenta cada vez mais desgaste. O mesmo se aplica ao caso da variação nos custos indiretos; estima-se que essa porcentagem seria maior no aparelho antigo, uma vez que estes custos estão diretamente ligados à manutenção.

A Tabela 4 apresenta a planilha de fluxo de caixa estimada para o período de 5 anos do Beckman Coulter T890 (aparelho antigo) e a Tabela 5, para o período de 10 anos em relação ao Sysmex XS800i (aparelho novo).

Tabela 4 - Fluxo de caixa estimado do aparelho antigo (Beckman Coulter T890)

\begin{tabular}{|c|c|c|c|c|c|c|c|c|c|}
\hline Período & $\begin{array}{c}(-) \\
\text { Investimento }\end{array}$ & $\begin{array}{c}\text { Receita } \\
\text { bruta }\end{array}$ & $\begin{array}{c}(-) \\
\text { Custos } \\
\text { diretos }\end{array}$ & $\begin{array}{c}(-) \\
\text { Custos } \\
\text { indiretos }\end{array}$ & $\begin{array}{c}(-) \\
\text { Depreciação }\end{array}$ & $\begin{array}{c}\text { Renda } \\
\text { tributável }\end{array}$ & $\begin{array}{c}(-) \\
\text { Imposto } \\
\text { de } \\
\text { renda }\end{array}$ & $\begin{array}{c}(+) \\
\text { Depreciação }\end{array}$ & $\begin{array}{l}\text { Lucro } \\
\text { líquido }\end{array}$ \\
\hline$\overline{0}$ & $\begin{array}{c}-\mathrm{R} \$ \\
10.000,00\end{array}$ & & & & & & & & $\begin{array}{c}-\mathrm{R} \$ \\
10.000,00\end{array}$ \\
\hline 1 & & $\begin{array}{c}\mathrm{R} \$ \\
75.000,00\end{array}$ & $\begin{array}{c}-\mathrm{R} \$ \\
21.450,24\end{array}$ & $\begin{array}{c}-\mathrm{R} \$ \\
2.000,00\end{array}$ & $\mathrm{R} \$ 0,00$ & $\begin{array}{c}\mathrm{R} \$ \\
51.549,76\end{array}$ & $\begin{array}{c}\mathrm{R} \$ \\
5.593,15\end{array}$ & $\mathrm{R} \$ 0,00$ & $\begin{array}{c}\text { \$ } \\
45.956,61\end{array}$ \\
\hline 2 & & $\begin{array}{c}\mathrm{R} \$ \\
71.250,00\end{array}$ & $\begin{array}{c}-\mathrm{R} \$ \\
22.522,75\end{array}$ & \begin{tabular}{|c|}
$-\mathrm{R} \$$ \\
$2.200,00$
\end{tabular} & $\mathrm{R} \$ 0,00$ & $\begin{array}{c}\mathrm{R} \$ \\
46.527,25\end{array}$ & $\begin{array}{c}-\mathrm{R} \$ \\
5.048,21\end{array}$ & $\mathrm{R} \$ 0,00$ & $\begin{array}{c}\mathrm{R} \$ \\
41.479,04\end{array}$ \\
\hline
\end{tabular}




\begin{tabular}{|c|c|c|c|c|c|c|c|c|}
\hline 3 & $\begin{array}{c}\mathrm{R} \$ \\
67.687,50\end{array}$ & $\begin{array}{c}-R \$ \\
23.648,89\end{array}$ & $\begin{array}{c}-R \$ \\
2.420,00\end{array}$ & $\mathrm{R} \$ 0,00$ & $\begin{array}{c}\mathrm{R} \$ \\
41.618,61\end{array}$ & $\begin{array}{c}-\mathrm{R} \$ \\
4.515,62\end{array}$ & $\mathrm{R} \$ 0,00$ & \begin{tabular}{|c}
$\mathbf{R} \$$ \\
$37.102,99$
\end{tabular} \\
\hline 4 & $\begin{array}{c}\mathrm{R} \$ \\
64.303,13\end{array}$ & \begin{tabular}{|c|}
$-\mathrm{R} \$$ \\
$24.831,33$
\end{tabular} & $\begin{array}{c}-R \$ \\
2.662,00\end{array}$ & $\mathrm{R} \$ 0,00$ & $\begin{array}{c}\mathrm{R} \$ \\
36.809,79\end{array}$ & \begin{tabular}{|c|}
$-\mathrm{R} \$$ \\
$3.993,86$
\end{tabular} & $\mathrm{R} \$ 0,00$ & $\begin{array}{c}\mathbf{R} \$ \\
32.815,93\end{array}$ \\
\hline 5 & $\begin{array}{c}\mathrm{R} \$ \\
61.087,97\end{array}$ & $\begin{array}{c}-R \$ \\
26.072,90\end{array}$ & $\begin{array}{c}-R \$ \\
2.928,20\end{array}$ & $\mathrm{R} \$ 0,00$ & $\begin{array}{c}\mathrm{R} \$ \\
32.086,87\end{array}$ & $\begin{array}{c}-\mathrm{R} \$ \\
3.481,43\end{array}$ & $\mathrm{R} \$ 0,00$ & \begin{tabular}{|c|}
$R \$$ \\
$28.605,44$
\end{tabular} \\
\hline
\end{tabular}

Fonte: Autoria Própria

Tabela 5 - Fluxo de caixa estimado do aparelho novo (Sysmex XS800i)

\begin{tabular}{|c|c|c|c|c|c|c|c|c|c|}
\hline Período & $\begin{array}{c}(-) \\
\text { Investimento }\end{array}$ & $\begin{array}{c}\text { Receita } \\
\text { bruta }\end{array}$ & $\begin{array}{l}\text { (-) Custos } \\
\text { diretos }\end{array}$ & $\begin{array}{c}(-) \\
\text { Custos } \\
\text { indiretos }\end{array}$ & $\begin{array}{c}(-) \\
\text { Depreciação }\end{array}$ & $\begin{array}{c}\text { Renda } \\
\text { tributável }\end{array}$ & $\begin{array}{c}(-) \\
\text { Imposto } \\
\text { de } \\
\text { renda }\end{array}$ & $\begin{array}{c}(+) \\
\text { Depreciação }\end{array}$ & $\begin{array}{l}\text { Lucro } \\
\text { líquido }\end{array}$ \\
\hline$\overline{0}$ & $\begin{array}{c}-\mathrm{R} \$ \\
58.360,00\end{array}$ & & & & & & & & $\begin{array}{c}-\mathrm{R} \$ \\
10.000,00\end{array}$ \\
\hline 1 & & $\begin{array}{c}\mathrm{R} \$ \\
75.000,00\end{array}$ & $\begin{array}{c}-\mathrm{R} \$ \\
20.170,08\end{array}$ & $\begin{array}{c}-\mathrm{R} \$ \\
3.500,00\end{array}$ & $-\mathrm{R} \$ 5.836,00$ & $\begin{array}{c}\mathrm{R} \$ \\
45.493,92\end{array}$ & $\begin{array}{c}-\mathrm{R} \$ \\
4.936,09\end{array}$ & $\mathrm{R} \$ 5.836,00$ & $\begin{array}{c}R \$ \\
46.393,83\end{array}$ \\
\hline 2 & & $\begin{array}{c}\mathrm{R} \$ \\
73.125,00\end{array}$ & $\begin{array}{c}-\mathrm{R} \$ \\
21.178,58\end{array}$ & $\begin{array}{c}-\mathrm{R} \$ \\
3.675,00\end{array}$ & $-\mathrm{R} \$ 5.836,00$ & $\begin{array}{c}\mathrm{R} \$ \\
42.435,42\end{array}$ & $\begin{array}{c}-\mathrm{R} \$ \\
4.604,24\end{array}$ & $\mathrm{R} \$ 5.836,00$ & $\begin{array}{c}\mathbf{R} \\
43.667,17\end{array}$ \\
\hline 3 & & $\begin{array}{c}\mathrm{R} \$ \\
71.296,88\end{array}$ & $\begin{array}{c}-\mathrm{R} \$ \\
22.237,51\end{array}$ & $\begin{array}{c}-\mathrm{R} \$ \\
3.858,75\end{array}$ & $-\mathrm{R} \$ 5.836,00$ & $\begin{array}{c}\mathrm{R} \$ \\
39.364,61\end{array}$ & $\begin{array}{c}-\mathrm{R} \$ \\
4.271,09\end{array}$ & $\mathrm{R} \$ 5.836,00$ & $\begin{array}{c}\mathbf{R} \$ \\
40.929,55\end{array}$ \\
\hline 4 & & $\begin{array}{c}\mathrm{R} \$ \\
69.514,45\end{array}$ & $\begin{array}{c}-\mathrm{R} \$ \\
23.349,39\end{array}$ & $\begin{array}{c}-\mathrm{R} \$ \\
4.051,69\end{array}$ & $-\mathrm{R} \$ 5.836,00$ & $\begin{array}{c}\mathrm{R} \$ \\
36.277,38\end{array}$ & $\begin{array}{c}-\mathrm{R} \$ \\
3.936,10\end{array}$ & $\mathrm{R} \$ 5.836,00$ & $\begin{array}{c}\mathbf{R} \$ \\
\mathbf{3 8 . 1 7 7 , 2 8}\end{array}$ \\
\hline 5 & & $\begin{array}{c}\mathrm{R} \$ \\
67.776,59\end{array}$ & $\begin{array}{c}-\mathrm{R} \$ \\
24.516,86\end{array}$ & $\begin{array}{c}-\mathrm{R} \$ \\
4.254,27\end{array}$ & $-\mathrm{R} \$ 5.836,00$ & $\begin{array}{c}\mathrm{R} \$ \\
33.169,46\end{array}$ & $\begin{array}{c}-\mathrm{R} \$ \\
3.598,89\end{array}$ & $\mathrm{R} \$ 5.836,00$ & $\begin{array}{c}\mathbf{R} \$ \\
35.406,58\end{array}$ \\
\hline 6 & & $\begin{array}{c}\mathrm{R} \$ \\
66.082,18\end{array}$ & $\begin{array}{c}-\mathrm{R} \$ \\
25.742,70\end{array}$ & $\begin{array}{c}-\mathrm{R} \$ \\
4.466,99\end{array}$ & $-\mathrm{R} \$ 5.836,00$ & $\begin{array}{c}\mathrm{R} \$ \\
30.036,49\end{array}$ & $\begin{array}{c}-\mathrm{R} \$ \\
3.258,96\end{array}$ & $\mathrm{R} \$ 5.836,00$ & $\begin{array}{c}\mathbf{R} \$ \\
32.613,53\end{array}$ \\
\hline 7 & & $\begin{array}{c}\mathrm{R} \$ \\
64.430,12\end{array}$ & $\begin{array}{c}-\mathrm{R} \$ \\
27.029,84\end{array}$ & $\begin{array}{c}-\mathrm{R} \$ \\
4.690,33\end{array}$ & $-\mathrm{R} \$ 5.836,00$ & $\begin{array}{c}\mathrm{R} \$ \\
26.873,95\end{array}$ & $\begin{array}{c}-\mathrm{R} \$ \\
2.915,82\end{array}$ & $\mathrm{R} \$ 5.836,00$ & $\begin{array}{c}\mathbf{R} \$ \\
29.794,13\end{array}$ \\
\hline 8 & & $\begin{array}{c}\mathrm{R} \$ \\
62.819,37\end{array}$ & $\begin{array}{c}-\mathrm{R} \$ \\
28.381,33\end{array}$ & $\begin{array}{c}-\mathrm{R} \$ \\
4.924,85\end{array}$ & $-\mathrm{R} \$ 5.836,00$ & $\begin{array}{c}\mathrm{R} \$ \\
23.677,19\end{array}$ & $\begin{array}{c}-\mathrm{R} \$ \\
2.568,98\end{array}$ & $\mathrm{R} \$ 5.836,00$ & $\begin{array}{c}\mathbf{R} \$ \\
26.944,21\end{array}$ \\
\hline 9 & & $\begin{array}{c}\mathrm{R} \$ \\
61.248,89\end{array}$ & $\begin{array}{c}-\mathrm{R} \$ \\
29.800,39\end{array}$ & $\begin{array}{c}-\mathrm{R} \$ \\
5.171,09\end{array}$ & $-\mathrm{R} \$ 5.836,00$ & $\begin{array}{c}\mathrm{R} \$ \\
20.441,40\end{array}$ & $\begin{array}{c}-\mathrm{R} \$ \\
2.217,89\end{array}$ & $\mathrm{R} \$ 5.836,00$ & $\begin{array}{c}\text { R\$ } \\
24.059,51\end{array}$ \\
\hline 10 & & $\begin{array}{c}\mathrm{R} \$ \\
59.717,66\end{array}$ & $\begin{array}{c}-\mathrm{R} \$ \\
31.290,41\end{array}$ & $\begin{array}{c}-\mathrm{R} \$ \\
5.429,65\end{array}$ & $-\mathrm{R} \$ 5.836,00$ & $\begin{array}{c}\mathrm{R} \$ \\
17.161,60\end{array}$ & $\begin{array}{c}-\mathrm{R} \$ \\
1.862,03\end{array}$ & $\mathrm{R} \$ 5.836,00$ & $\begin{array}{c}\mathbf{R} \$ \\
21.135,57\end{array}$ \\
\hline
\end{tabular}


A partir das planilhas de fluxo de caixa, foi possível calcular o VAUE do aparelho antigo e do aparelho novo, de acordo com os períodos analisados em relação a cada um deles. Esses valores podem ser observados na Tabela 6. A taxa mínima de atratividade utilizada foi de $17 \%$ ao ano, baseada na Taxa de Juros Selic em outubro de 2016 ( $14 \%$ ao ano), com uma margem de $+3 \%$, definida pelo investidor em questão.

Tabela 6 - VAUE de cada aparelho no período determinado

\begin{tabular}{cc}
\hline Aparelho considerado & VAUE \\
\hline Beckman Coulter T890 & $\mathrm{R} \$ 35.415,25$ \\
Sysmex XS800i & $\mathrm{R} \$ 24.865,36$
\end{tabular}

Fonte: Autoria Própria

Esses valores indicam que teria sido mais vantajoso em termos financeiros para o laboratório seguir utilizando o Beckman Coulter T890 para automação em hematologia, no lugar da aquisição do Sysmex XS800i, embora o segundo trabalhe com uma tecnologia mais avançada e consequentemente tenha uma confiabilidade maior em seus resultados. Os cálculos do VAUE para o aparelho antigo em relação a outros períodos (Tabela 7) indicou que a vida econômica do aparelho seria de 2 anos, ou seja, seria interessante mantê-lo por esse período de tempo e em seguida, trocá-lo por um similar. Assim, a substituição idêntica teria economicamente sido a decisão ideal.

Tabela 1 - VAUE do aparelho antigo por período (em anos)

\begin{tabular}{c|r}
\hline Período & \multicolumn{1}{l}{ VAUE } \\
\hline 1 & $\mathrm{R} \$ 34.256,61$ \\
\hline 2 & $\mathrm{R} \$ 37.584,92$ \\
\hline 3 & $\mathrm{R} \$ 37.448,74$ \\
\hline 4 & $\mathrm{R} \$ 36.547,50$ \\
\hline 5 & $\mathrm{R} \$ 35.415,25$ \\
\hline \multicolumn{2}{|c}{ Fonte: Autoria Própria }
\end{tabular}

Levando em consideração a situação real, em que houve a aquisição do aparelho Sysmex XS800i, é interessante calcular a vida econômica do equipamento para que se saiba o período ideal para sua substituição por outro similar. Assim, também foi realizado o cálculo do VAUE em outros períodos para o equipamento novo (Tabela 8). 
Tabela 2 - VAUE do aparelho antigo por período (em anos)

\begin{tabular}{c|c}
\hline Período & VAUE \\
\hline 1 & $-\mathrm{R} \$ 21.887,37$ \\
\hline 2 & $\mathrm{R} \$ 8.322,10$ \\
\hline 3 & $\mathrm{R} \$ 17.536,11$ \\
\hline 4 & $\mathrm{R} \$ 21.551,50$ \\
\hline 5 & $\mathrm{R} \$ 23.526,73$ \\
\hline 6 & $\mathrm{R} \$ 24.513,69$ \\
\hline 7 & $\mathrm{R} \$ 24.962,25$ \\
\hline 8 & $\mathrm{R} \$ 25.096,41$ \\
\hline 9 & $\mathrm{R} \$ 25.039,70$ \\
\hline 10 & $\mathrm{R} \$ 24.865,36$ \\
\hline
\end{tabular}

Fonte: Autoria Própria

A partir desses resultados, é possível observar que o maior VAUE ocorre no período 8, que é igual à vida econômica do aparelho e, portanto, determina o momento ótimo para sua substituição idêntica. O período payback do investimento inicial de $\mathrm{R} \$ 58.360,00$ foi calculado pelo método do payback descontado, a partir do valor presente líquido obtido em cada período do fluxo de caixa, por meio do software Microsoft Excel. Dessa maneira, constatou-se que o período estimado de retorno desse investimento é de 2 anos, já que neste período, o VPL deixa de ser negativo. Os valores de VPL do aparelho novo estão demonstrados na Tabela 9.

Tabela 3 - VPL do equipamento novo por período (em anos)

\begin{tabular}{c|c}
\hline Período & VPL \\
\hline 1 & $-\mathrm{R} \$ 18.707,15$ \\
\hline 2 & $\mathrm{R} \$ 13.192,31$ \\
\hline 3 & $\mathrm{R} \$ 38.747,51$ \\
\hline 4 & $\mathrm{R} \$ 59.120,82$ \\
\hline 5 & $\mathrm{R} \$ 75.270,16$ \\
\hline 6 & $\mathrm{R} \$ 87.984,17$
\end{tabular}




\begin{tabular}{c|c}
7 & $\mathrm{R} \$ 97.911,44$ \\
\hline 8 & $\mathrm{R} \$ 105.584,67$ \\
\hline 9 & $\mathrm{R} \$ 111.440,85$ \\
\hline 10 & $\mathrm{R} \$ 115.837,83$ \\
\hline
\end{tabular}

Fonte: Autoria Própria

\section{CONSIDERAÇÕES FINAIS}

O estudo permitiu perceber a importância da realização de uma análise de investimento antes de qualquer tomada de decisão de capital dentro de uma empresa. Esse tipo de procedimento tem como objetivo reduzir os riscos e incertezas do investimento, sendo uma ferramenta estratégica.

A elaboração de fluxo de caixa, aliada aos métodos do VAUE e do período payback, são capazes de orientar o investidor a partir de uma análise de substituição de equipamentos, como demonstrado ao longo do artigo. Caso o presente estudo tivesse sido realizado anteriormente à aquisição do novo equipamento, a empresa em questão possivelmente não teria obtido prejuízo financeiro.

Apesar da análise apresentada, muitas variáveis estão envolvidas na avaliação de um investimento. 0 fato de o aparelho novo ter vantagens tecnológicas e de confiabilidade em relação ao equipamento antigo provavelmente tenha sido determinante no momento de sua aquisição. $O$ desafio das organizações na atualidade é justamente conseguir conciliar esses dois aspectos, encontrando alternativas para que o avanço tecnológico esteja presente ao mesmo tempo em que seja um aliado em relação ao aspecto econômico-financeiro. 


\section{REFERÊNCIAS}

BANCO CENTRAL DO BRASIL. Taxa SELIC: Dados Diários. Disponível em: <http://www.bcb.gov.br/? SELICDIARIOS>. Acesso em 28 nov. 2016.

BRITO, Paulo. Análise e Viabilidade de Projetos de Investimentos. 2. ed. São Paulo: Atlas, 2011.

DALBELLO, Liliane. A relevância do uso do fluxo de caixa como ferramenta de gestão financeira para avaliação da liquidez e capacidade de financiamento de empresas. Tese (Mestrado) - Programa de Pós-Graduação em Engenharia de Produção, Área de Concentração em Engenharia de Avaliação e Inovação Tecnológica, Universidade Federal de Santa Catarina, Florianópolis, 1999.

GASLENE, Alain et al. Decisões de Investimentos da Empresa. 1. ed. São Paulo: Atlas, 1999.

GUILHOTO, Lúcia de Fátima Martins. O uso da Internet como ferramenta para a oferta diferenciada de serviços a clientes corporativos: um estudo exploratório no setor de telecomunicações. São Paulo: USP, 2002. Tese (Mestrado) - Programa de Pós-Graduação em Administração, Faculdade de Economia, Administração e Contabilidade, Universidade de São Paulo, São Paulo, 2002.

KASSAI, José Roberto et al. Retorno de Investimento: Abordagens Matemática e Contábil do Lucro Empresarial. 3. ed. São Paulo: Atlas, 2007.

MOTTA, Regis da Rocha; CALÔBA, Guilherme Marques. Análise de Investimentos: Tomada de Decisão em Projetos Industriais. 1. ed. São Paulo: Atlas, 2002.

MUGNOL, Katia Cristina Ugolini; FERRAZ, Marcos Bosi. Sistema de informação como ferramenta de cálculo e gestão de custos em laboratórios de análises clínicas. J. Bras. Patol. Med. Lab., Rio de Janeiro, v. 42, n. 2, p. 95-102, Apr. 2006. Disponível em

<http://www.scielo.br/scielo.php?script=sci_arttext\&pid=S167624442006000200006\&lng=en\&nrm= iso>. Acesso em 16 nov. 2016.

SILVA, Breno Augusto de Oliveira et al. Determinação do momento ótimo para substituição de equipamentos sob as óticas da gestão econômica e da engenharia econômica. In: XXXII ENEGEP, Encontro Nacional de Engenharia de Produção. Disponível em <http://www.abepro.org.br/biblioteca/enegep2012_TN_STO_159_926_20483.pdf>. Acesso em 14 nov. 2016.

SILVA, Henrique Mendes; SANTIAGO, Leonardo Pereira. Análise de viabilidade da substituição de equipamentos sob incerteza: o caso da São Bento Mineração S.A. In: XXVI ENEGEP, Encontro Nacional de Engenharia de Produção. Fortaleza, 2006. Disponível em <http://www.abepro.org.br/biblioteca/ ENEGEP2006_TR510344_7705.pdf>. Acesso em 15 nov. 2016.

SINDIFARS - Sindicato dos Farmacêuticos no Estado do Rio Grande do Sul. Campanha salarial de 2016. Porto Alegre: abril/maio/junho de 2016. Disponível em <http://www.sindifars.com.br/pauta-2016aprovada>. Acesso em 15 nov. 2016.

SOUZA, Alceu; CLEMENTE, Ademir. Decisões Financeiras e Análise de Investimentos: Fundamentos, Técnicas e Aplicações. 6. ed. São Paulo: Atlas, 2012.

YIN, Robert K. Estudo de Caso: Planejamento e Métodos. 5. ed. Porto Alegre: Bookman, 2015. 


\section{Capítulo 10}

\section{ANÁLISE ERGONÔMICA DE UM PRODUTO DE CONSUMO: O CASO DE UM BEBEDOURO DE MESA TIPO GELÁGUA}

Marilande Carvalho de Andrade Silva

Waldelourdes de Melo Souto Maior

Alaíde Farias de Almeida Filha

Marcelo Márcio Soares
Universidade Federal de Pernambuco

Universidade Federal de Pernambuco

Universidade Federal de Pernambuco

Universidade Federal de Pernambuco 
Resumo: Este artigo relata a avaliação ergonômica de um bebedouro. Foram feitas entrevistas para avaliar a satisfação dos usuários. Para fundamentação, aplicamos a etapa de apreciação do sistema humano-tarefa-máquina Moraes e Mont'Alvão (2000); para delinearmos as características do design, fizemos uma análise de acordo com os princípios de usabilidade de Jordan (1998).

Palavras-chave: Ergonomia, produto de consumo, bebedouro. 


\section{INTRODUÇÃO}

A água é um recurso natural de suma importância para a existência dos organismos, o que seria improvável imaginar a sobrevivência de alguma forma de vida na ausência deste insumo vital. Seu fornecimento em quantidade e qualidade é fundamental para a perfeita manutenção da vida humana (PEZZARINO, 2010).

Bebedouros são produtos de consumo de extrema necessidade em diversos ambientes públicos e privados, porém a maioria deles possuem deficiências quanto a ergonomia, acessibilidade e usabilidade (DANTAS et al, 2010).

Do ponto de vista ergonômico, os produtos são considerados como meios para que o homem possa executar determinadas funções. Esses produtos passam então a fazer parte de sistemas homemmáquina-ambiente.

Nesse contexto, o objetivo da Ergonomia é estudar esses sistemas, para que as máquinas e ambientes possam funcionar harmoniosamente com o homem, de modo que o desempenho dos mesmos seja adequado (IIDA, 2005).

Delineando as características do design associadas à usabilidade dos produtos de acordo com os princípios de usabilidade de Jordan (1998), foi feito a classificação do produto em estudo, seguido da análise da segurança durante seu uso.

Na análise do produto, a usabilidade, que significa facilidade e comodidade no uso dos produtos tanto no ambiente doméstico como no profissional, assume um papel importante.

Em geral, lida e Guimarães (2016), consideram que os produtos devem ser "amigáveis", fáceis de entender e fáceis de operar.

\section{OBJETIVO}

Analisar ergonomicamente um produto de consumo, o bebedouro de mesa tipo gelágua de marca Esmaltec, modelo EGM 30.

\section{METODOLOGIA}

O presente artigo baseou-se na análise ergonômica de um bebedouro de mesa tipo gelágua, fazendo uso de uma pesquisa de cunho descritivo-exploratório e quanti-qualitativa. 
Para atingir o objetivo, foi feito uma pesquisa bibliográfica sobre o assunto abordado, a fim de compreender e evidenciar a importância do estudo. Baseando-se do assunto na literatura especializada através de projetos, artigos, relatórios, manuais e outras fontes que tratam do tema.

Seguimos com a apresentação do produto, apresentando sua identificação, funções, características e especificações técnicas; seus sistemas e subsistemas.

Em seguida, foi apresentada a problematização do Sistema Humano-Tarefa-Máquina, ilustrando a categorização dos problemas ergonômicos, as atividades de uso, os atributos ergonômicos no design do produto e os parâmetros ergonômicos, bem como o design e os tipos de pegas apropriadas para o seu uso.

Para a análise ergonômica da tarefa utilizamos parte da metodologia de Moraes e Mont'Alvão (2000), onde aplicamos a etapa de apreciação das disfunções do Sistema Humano-Tarefa-Máquina (STHM), a representação esquemática das interações entre os elementos de um sistema humano-tarefamáquina; o fluxograma funcional ação-decisão, onde apresentamos a análise da principal tarefa do bebedouro, que é dispensar água.

Em seguida, delineamos as características do design associadas à usabilidade do produto de acordo com os princípios de usabilidade de Jordan (1998). Também foi feita a classificação do produto em estudo, seguida da análise da segurança durante o seu uso.

\section{APRESENTAÇÃO DO PRODUTO}

\subsection{IDENTIFICAÇÃO:}

Bebedouro de mesa tipo gelágua Esmaltec EGM30

Figura 1. Identificação do produto

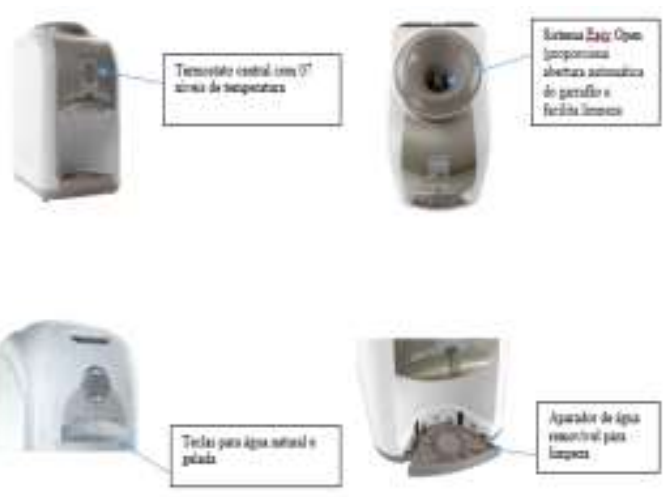

Fonte: Manual de instruções Esmaltec 


\subsection{FUNÇÕES:}

O produto em estudo apresenta função Mix (permite a mistura de água natural e gelada com apenas um toque), e a refrigeração da água é feita por meio de um compressor.

\subsection{CARACTERÍSTICAS E ESPECIFICAÇÕES TÉCNICAS DO PRODUTO}

Quadro 1. características e especificações técnicas

\begin{tabular}{|l|l|}
\hline \multicolumn{2}{|c|}{ Características } \\
\hline Cor & Branco \\
\hline Aprovado pelo INMETRO & Sim \\
\hline Capacidade & $3 \mathrm{~L}$ \\
\hline Fácil instalação & Sim \\
\hline Modelo & Mesa \\
\hline Tipo de refrigeração & Compressor \\
\hline Ajuste/controle de temperatura & Sim \\
\hline Silencioso & Sim \\
\hline Indicadores luminosos & Não \\
\hline Jato de água direcionável & Não \\
\hline Ligado à rede de água & Não \\
\hline Ozonizador, Purificador & Não \\
\hline Garantia & 12 meses \\
\hline & Especificações Técnicas \\
\hline Peso & $12,5 \mathrm{Kg}$ \\
\hline Altura & $420 \mathrm{~mm}$ \\
\hline Largura & $280 \mathrm{~mm}$ \\
\hline Profundidade & $410 \mathrm{~mm}$ \\
\hline Capacidade do reservatório & $10 \mathrm{a} 20$ litros \\
\hline Potência & $97 \mathrm{Wats}$ \\
\hline Temperatura & $5 \mathrm{a} 15^{\circ} \mathrm{C}$ \\
\hline Voltagem & $220 \mathrm{~V}$ \\
\hline Fácil limpeza & SIM \\
\hline Tipo de água (natural/gelada) & $\begin{array}{l}\text { Natural } \\
\text { gelada }\end{array}$ \\
\hline Tipo do bebedouro & Compressor \\
\hline $\begin{array}{l}\text { Consumo aproximado de } \\
\text { energia }\end{array}$ & $0,054 \mathrm{kw} / \mathrm{h}$ \\
\hline Comprimento & $41.2 \mathrm{~cm}$ \\
\hline
\end{tabular}

\subsection{SISTEMAS E SUBSISTEMAS}

A Figura 3, abaixo, apresenta os componentes do sistema à partir da Ordenação hierárquica do sistema. 
Figura 2. Ordenação hierárquica do sistema

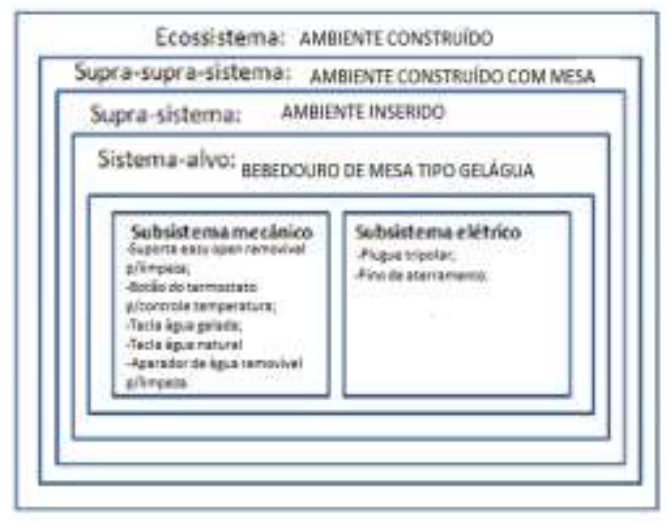

\subsubsection{SUBSISTEMA MECÂNICO}

O subsistema mecânico do produto em análise é constituído pelos seguintes elementos: Suporte Easy Open removível para a limpeza, botão do termostato para o controle da temperatura, tecla para água natural, tecla para água gelada e aparador de água removível para limpeza.

\subsubsection{SUBSISTEMA ELÉTRICO}

Na análise de segurança elétrica, há risco mínimo de sofrer um choque quando for pegar um copo com água, pois o subsistema elétrico é composto por plugue tripolar e pino de aterramento.

O bebedouro de mesa tipo gelágua é bastante versátil. Tem bandeja coletora de água e teclas individuais para dispensação de água natural e água gelada.

\subsubsection{PERSPECTIVA EXPLODIDA}

Figura 3. Vista explodida do bebedouro gelágua

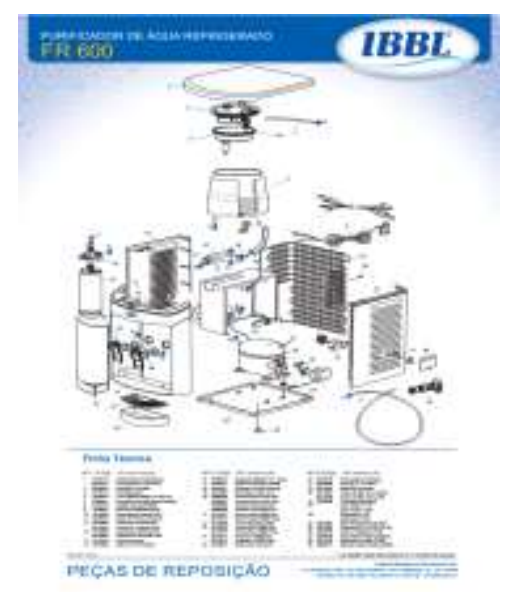


A figura acima mostra a vista explodida do bebedouro gelágua, apresentando uma visão ampla das várias peças que compõe o produto e tem como objetivo a possível reposição das mesmas.

\section{PROBLEMATIZAÇÃO DO SISTEMA HUMANO-TAREFA-MÁQUINA}

Durante as observações nos deparamos com algumas dificuldades. A delimitação do sistema alvo com a caracterização do sistema humano-tarefa e posição serial do sistema, compreendem todos os requisitos, entradas e saídas com relação a tarefa do usuário de como todo o sistema é alimentado desde a colocação do garrafão sobre o bebedouro, verificação de existência de energia elétrica, dispensação de água e até a verificação da água.

A figura abaixo representa esquematicamente a categorização e posição serial do sistema alvo, que é o bebedouro.

Figura 4. Caracterização e posição serial do SHTM do Bebedouro

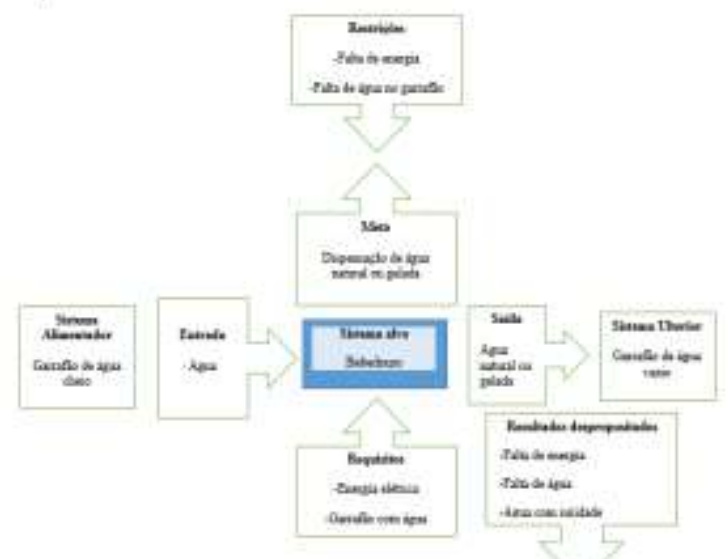

\subsection{CATEGORIZAÇÃO DOS PROBLEMAS ERGONÔMICOS}

A partir da observação do usuário realizando a tarefa de beber água, complementamos o processo de problematização e podemos visualizar e analisar de maneira objetiva os problemas interfaciais, de acessibilidade, informacionais e instrumentais.

Quadro 2. Caracterização dos problemas ergonômicos

\begin{tabular}{|l|l|}
\hline Problemas & Caracterização \\
\hline Interfacias & $\begin{array}{l}\text { Na etapa da tarefa de beber água o anglo de visão do percentil maior (97,5\%) } \\
\text { está fora do alcance do usuário, o que poderá prejudicá-lo devido a má postura } \\
\text { ao realizar esta etapa da tarefa. }\end{array}$ \\
\hline Acessibilidade & $\begin{array}{l}\text { O painel de informação do bebedouro não contém braile nas teclas } \\
\text { natural/gelada, dificultando a tomada de informações de acionamentos por } \\
\text { usuários portadores de deficiência visual. }\end{array}$ \\
\hline
\end{tabular}




\begin{tabular}{|l|l|}
\hline Informacionais/visuais & $\begin{array}{l}\text { A ausência de signos visuais dificulta a fácil interação da interação com seus } \\
\text { usuários. }\end{array}$ \\
\hline Instrumentais & $\begin{array}{l}\text { O espaço entre as teclas de água natural/gelada e o aparador de água é muito } \\
\text { curto, impedindo assim que o usuário utilize copos de diversos tamanhos. }\end{array}$ \\
\hline
\end{tabular}

\subsection{DISFUNÇÕES ERGONÔMICAS}

A principal disfunção ergonômica constatada durante a análise deste produto foi de natureza interfacial, consistindo na má postura durante a realização da tarefa.

\subsection{DISFUNÇÕES DO ELEMENTO MÁQUINA}

As disfunções do bebedouro foram levantadas fundamentadas nas observações feitas a partir dos usuários e da observação ao produto. E foram encontradas as seguintes disfunções a serem corrigidas:

- Desempenho do sistema e confiabilidade, consistindo na deficiência do desempenho quando não atinge a capacidade no que tange à eficiência, qualidade e conformidade;

- O bebedouro não é bivolt, o que causa problema de usar o produto em lugares em que a voltagem é diferente;

- Não há compartimento para arrumação do fio no bebedouro deixando-o sempre exposto e desarrumado.

\section{ATIVIDADE DE USO}

\subsection{MODELO OPERACIONAL DO SISTEMA HUMANO MÁQUINA}

Esta fase é basicamente representada com a transmissão de informação, compreendendo os subsistemas humanos de tomada de informação/percepção (sentidos humanos envolvidos); os subsistemas humanos de resposta/regulação (ações realizadas); os subsistemas da máquina que fornecem informações para serem processadas pelo homem e os subsistemas da máquina que recebem as ações do homem (MORAES; MONT'ALVÃO, 2012). 
Figura 5. Modelagem comunicacional do Sistema Humano Máquina

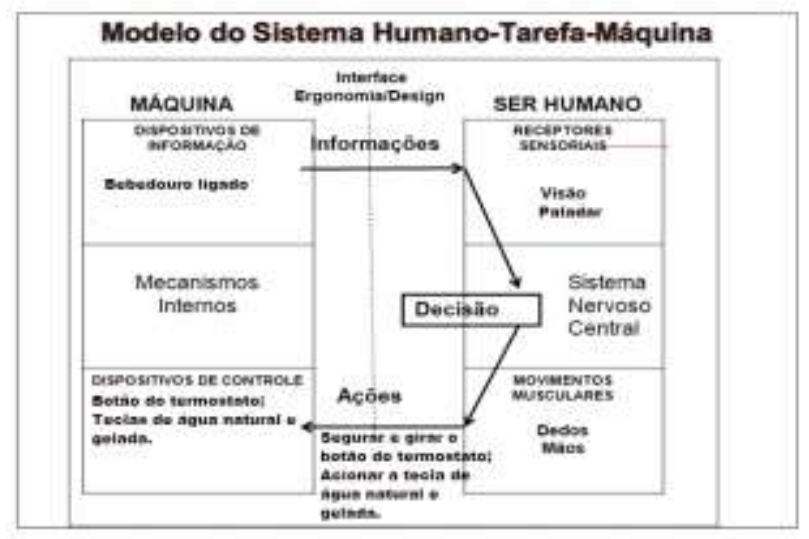

A figura acima se refere à sucessão das informações/operações, através de fontes de interação, com a utilização do sistema humano na tomada das decisões implicadas pelos sentidos humanos envolvidos (visão e paladar), as respostas humanas e os componentes acionais (sistema máquina), informações fornecidas pela máquina para o ser humano durante a realização da tarefa.

\subsection{ALOCAÇÃO DE FUNÇÕES E TAREFAS}

Nesta fase foi elaborado um quadro com as diversas funções do equipamento, discriminando as funções e tarefas melhor desempenhadas pelo humano e pela máquina.

Quadro 3. Alocação de funções

\begin{tabular}{|l|l|}
\hline Funções e Tarefas & Melhor desempenho \\
\hline Escolher o comando no painel & Humano \\
\hline Beber água natural ou gelada & Humano \\
\hline Colocar o copo no dispensador de água & Humano \\
\hline Programar a temperatura da água & Humano \\
\hline Ligar/Desligar a máquina & Humano \\
\hline Tirar a água da máquina & Humano \\
\hline Colocar garrafão de água no bebedouro & Humano \\
\hline Gelar a água & Máquina \\
\hline Controlar a temperatura da água & Máquina \\
\hline
\end{tabular}

\subsection{ANÁLISE DA TAREFA}

Esta fase incluiu o conhecimento e a ordenação das atividades da tarefa e a construção de um fluxograma de atividades.

- Colocar o garrafão no sistema Easy Open do bebedouro; 
- Ligar o plugue na rede elétrica;

- Selecionar no botão do termostato, a temperatura desejada;

- Colocar o copo no aparador de água;

- Acionar a tecla (natural ou gelada) para encher o copo com água;

- Retirar do aparador o copo com água;

- Beber a água natural ou gelada.

Figura 6. Fluxograma funcional ação decisão (tarefa beber água)

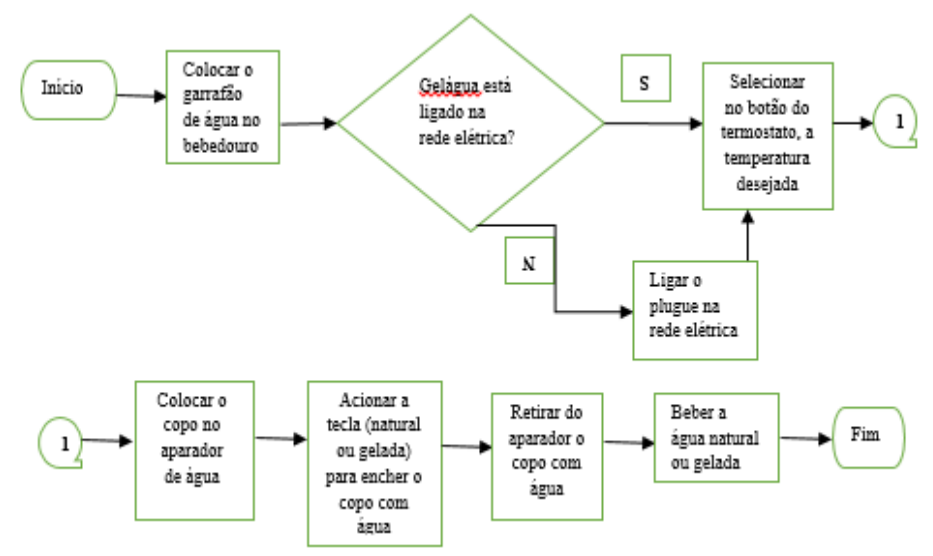

Neste fluxograma encontra-se ilustrada a análise da tarefa (beber água), utilizando-se o produto bebedouro de mesa tipo gelágua.

\subsection{IDENTIFICAÇÃO E ANÁLISE DOS ATRIBUTOS ERGONÔMICOS NO DESIGN DO PRODUTO.}

Ao realizar a análise do produto em estudo, os seguintes atributos ergonômicos foram identificados:

Segurança: Desde que sejam cumpridas as instruções de segurança do manual do produto, este gelágua é considerado seguro. O plugue oferece proteção ao usuário por já ter sido confeccionado no modelo padrão e assim não gera desconforto por necessitar de um adaptador para ligá-lo na tomada. O manual é objetivo e claro sobre a questão de segurança e uso correto do produto. Além disso, possui um item chamado "solução de problemas" que permite ao usuário identificar eventuais problemas não relacionados a problemas de fábrica. Dessa forma, evita idas desnecessárias a assistências técnicas do produto.

Eficiência: A partir desta análise, pôde-se inferir que o produto é considerado eficiente, uma vez que atende a sua proposta inicial, que é gelar a água, de acordo com a programação selecionada previamente por cada usuário. 
Satisfação no uso: Basicamente, os usuários demonstram-se satisfeitos com o gelágua, pelo fato de ele atender à proposta de gelar a água. O manuseio é simples e basta seguir o Manual de Instruções, a sua utilização é simples e fácil.

Durabilidade: O material de fabricação é considerado robusto, o que contribui para a sua durabilidade, desde que seja conservada em local que o proteja do sol ou de qualquer outro elemento abrasivo ou líquido.

Adequação ao uso: Em relação ao posicionamento do gelágua, por convenção, deve ser colocado em cima de um balcão ou de uma mesa ao ser utilizado para o fim ao qual se destina, o usuário assume uma postura adequada, que não exige muita força física nem precisa realizar movimentos repetitivos.

Preço realístico: Considerando o valor cobrado por eletrodomésticos do mesmo porte, o preço do gelágua encontra-se dentro da média, entre $\mathrm{R} \$ 390,00$ a 480,00 dependendo da loja. Acredita-se que seja um preço realístico, ao compará-lo com os demais eletrodomésticos.

Boa aparência: Em geral, o design do gelágua apresenta uma boa aparência. Atende ao estereótipo popular de eletrodoméstico para mesa ou balcão de cozinha, bastando apenas se familiarizar com o design moderno e as informações do painel do produto.

\section{ANÁLISE DAS FUNÇÕES ERGONÔMICAS PARA O RELACIONAMENTO ENTRE O OBJETO DE} ESTUDO E O USUÁRIO SEGUNDO LOBACH (2001), AS FUNÇÕES DE UM PRODUTO SÃO APRESENTADAS COMO SÃO PERCEBIDAS PELO CONSUMIDOR.

Nesse contexto, o design atua como um método de concepção premeditada e tem como objetivo atender as necessidades propostas pelo produto.

Há um consenso sobre o fato de que um bom produto deve cumprir com suas finalidades da forma mais completa possível e diante desse preceito, é importante detectar os possíveis problemas com o produto.

Assim, devem ser feitas verificações nas seguintes categorias: função, utilização e finalidade.

1. Função: Analisar quais são as funções primárias e secundárias do produto;

2. Utilização: Observar quais são as formas de utilização do produto;

3. Finalidade: Investigar qual é a tarefa final proposta pelo produto.

A função do produto é classificada teoricamente das seguintes formas: 
Prática: diz respeito à capacidade do produto em atender a uma necessidade de uso. Nesse sentido, a função prática dos produtos de design pode ser avaliada segundo a sua usabilidade, ou seja, um produto deve ser usado para alcançar objetivos específicos como efetividade, eficiência e satisfação.

Estética: diz respeito à capacidade de sensibilizar pelo menos um dos sentidos humanos. Assim, os produtos devem ser projetados de forma que os elementos estéticos (cores, formas, texturas, sons, entre outros) se relacionem entre si de forma harmoniosa, e cumpram a função de atrair a atenção e seduzir os usuários.

Simbólica: visa estabelecer uma relação de significação, relacionada a algo que lembra ou indica um conceito. Além de criar uma experiência de uso, os elementos curvilíneos e as cores suaves criam uma experiência de marca para os seus usuários.

A análise do bebedouro tipo gelágua permitiu a conclusão de que ele cumpre o seu papel, segue estereótipos populares por apresentar opções de escolha para água natural e gelada e não são necessários movimentos repetitivos por um longo tempo.

Quanto à esfera da Usabilidade, nesta análise foram utilizadas as dimensões propostas por Kim e Han (2008), para heurísticas de usabilidade para produtos de consumo eletrônicos. Então o bebedouro foi assim analisado:

Simplicidade: O método de interação do produto com o usuário é simples, claro e intuitivo. Basta que o usuário leia as instruções.

Consistência: A interface é consistente dentro do produto e entre produtos da mesma família.

Controle do usuário: O usuário tem total autoridade para controlar as funções do bebedouro.

Feedback: O status do produto e as consequências de qualquer operação do usuário são fornecidas de forma clara e imediata.

Mensagem de erro: Não se aplica ao produto em análise.

Adaptabilidade: Significa que modificações da interface devem encaixar diferentes usuários e condições de acordo com a experiência, conhecimento e preferências dos mesmos. Partindo desse pressuposto, este produto apenas oferece um roteiro único a ser seguido por todos os tipos de usuário.

Acessibilidade: Como todas as funções são facilmente visualizadas, esse produto foi considerado acessível. 
Capacidade de aprendizado: Pelo fato de um o produto ser intuitivo e das informações estarem expostas, por extenso, o esforço necessário para o aprendizado do usuário é pequeno.

Memorização: Pelo fato das informações serem legíveis, o usuário tem facilidade de lembrar os métodos de interação.

Familiaridade: Este conceito está presente, apesar de alguns usuários não terem acesso a outro tipo de bebedouro anteriormente. Mas pela clareza de uso, é fácil associar o seu uso aos de outros produtos similares.

Informativa: A interface foi considerada de compreensão fácil e clara.

Eficácia: Todos a programação está disponível, podendo ser visualizados por facilmente.

Eficiência: Este produto foi projetado para permitir que o usuário execute funções de forma fácil.

\section{ANÁLISE DOS TIPOS DE PEGA UTILIZADAS NO BEBEDOURO}

O bebedouro em análise não apresenta alças ou pegas destinadas a sua locomoção, porém apresenta pegas para utilização do produto. Também existe o utensílio como copo que é manuseado durante a utilização do produto. Para utilização do produto em estudo e de seu utensílio, o usuário faz uso de pegas classificadas como prênseis ou não-prênseis, como veremos mais detalhadamente na sequência.

\subsection{POSIÇÕES DE PEGAS EMPREGADAS DURANTE A UTILIZAÇÃO DO BEBEDOURO}

Essa classificação foi feita considerando as relações mão-objeto e pegas usadas durante a utilização do bebedouro analisado.

8.1.1 Pega "toque de dedos" - A pega "toque de dedos" é uma pega prênsil, utilizada para selecionar no termostato, a temperatura da água e as teclas de liberação de água natural e gelada, conforme ilustrado na figura abaixo. 
Figura 7. Tipo de pega: Pega toque de dedos

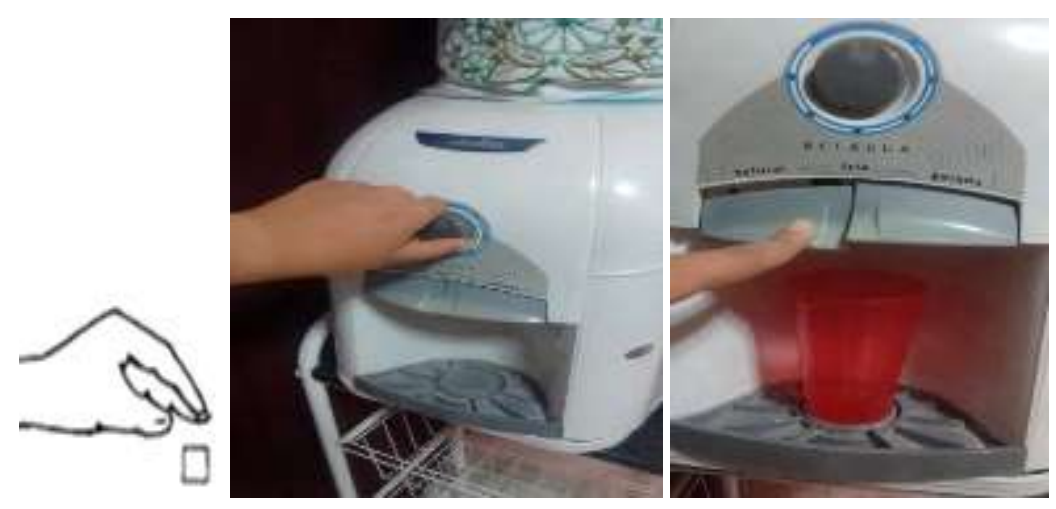

8.1.2 Pega "palma dedos" - A forma da pega dos copos (elemento utilizado durante a realização da tarefa de beber água) tem forma anatômica, cilíndrica, encaixa bem na mão do usuário, seja ele homem ou mulher.

Figura 8. Tipo de pega: Palma dedos

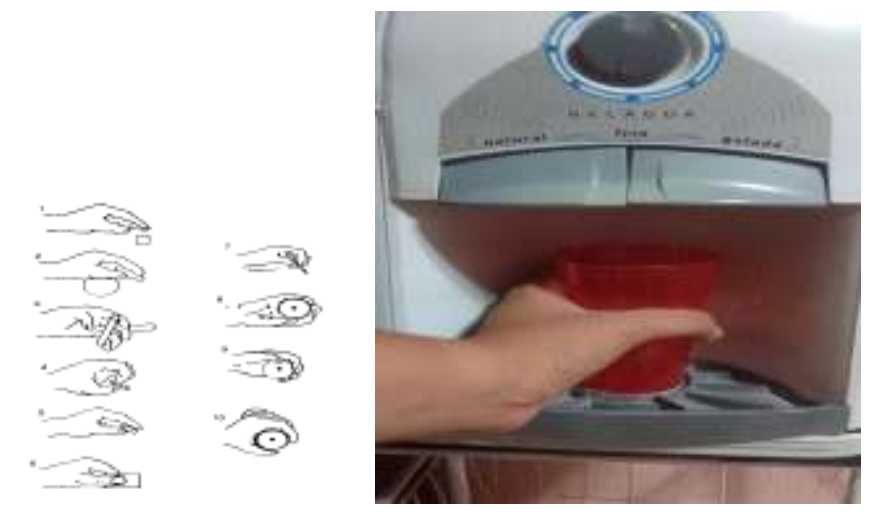

\section{CLASSIFICAÇÃO DO TIPO DE PRODUTO E RECOMENDAÇÕES PARA SUA CONFIGURAÇÃO}

Nesta etapa foram verificadas as características físicas do bebedouro que é classificado como um produto portável. Os dados e as diretrizes para a configuração deste produto relacionam-se à dimensão do produto, forma, peso e característica de pega. O bebedouro atende a orientação de peso máximo recomendado para produtos que serão suspensos (Zona de suspensão da altura do nó dos dedos a altura do ombro), cujo limite máximo para mulheres é de 5,9 kg e para homens de 15,4 Kg, pois pesa $12,5 \mathrm{Kg}$. As medidas do bebedouro estão exibidas na figura abaixo. 
Quadro 4. Peso e tamanho do bebedouro

\begin{tabular}{|l|l|}
\hline Peso e Tamanho & $\begin{array}{l}\text { Bebedouro } \\
\text { gelágua } \\
\end{array}$ \\
Esmaltec-EGM \\
$\mathbf{3 0}$ \\
\hline Peso & $12,5 \mathrm{Kg}$ \\
\hline Altura & $420 \mathrm{~mm}$ \\
\hline Largura & $280 \mathrm{~mm}$ \\
\hline Profundidade & $410 \mathrm{~mm}$ \\
\hline
\end{tabular}

\section{ANÁLISE DA SEGURANÇA DO PRODUTO}

Após a análise realizada da segurança do bebedouro, foram relacionados os tipos de perigo potencial e apresentadas estratégias visando a redução desses riscos, por meio de recomendações direcionadas à segurança do produto em estudo.

Choque elétrico: Não ligar o bebedouro e não tocar no cabo elétrico utilizando as mãos molhadas, não ligá-lo sobre uma superfície com água, não imergir o plugue/cabo elétrico na água ou em qualquer outro líquido. O plugue deve ser desconectado da rede elétrica antes de iniciar a sua limpeza.

Possíveis danos ao utilizar uma tensão com voltagem diferente: Certificar-se que o tipo de tensão do produto equivale ao do domicílio do usuário.

Riscos para incêndio: Não ligar o produto em tomadas elétricas sobrecarregadas com outros produtos simultaneamente.

\section{ANÁLISE DE CAMPO COM USUÁRIOS}

A metodologia empregada nesta análise de campo foi baseada no estudo de Sabino Neto et al. (2004), fazendo uma adaptação ao produto em estudo. Consistiu na observação direta de 10 usuários, durante a utilização do bebedouro em suas residências. Cada usuário foi solicitado a realizar a tarefa de beber água, com o intuito de verificar o funcionamento e a usabilidade percebida. A seguir, foi aplicado um questionário de satisfação com o produto e para verificar a opinião dos usuários em relação ao bebedouro, elaboramos um questionário contendo dados gerais como: Idade e gênero, uso do produto, frequência de uso, qual programação costuma utilizar (água natural ou gelada), material do produto, satisfação em relação à limpeza, aspectos ergonômicos, opinião sobre o design do produto (se considera agradável, silencioso, eficaz, seguro, se recomendaria o produto e se vivenciou algum 
acidente durante o uso). E como resultados: dos usuários entrevistados, 15\% eram do sexo masculino e $85 \%$ eram do sexo feminino, com idades de 30 a 50 anos. Em relação ao uso do produto, $95 \%$ dos usuários utilizam o produto com muita frequência e selecionam geralmente a programação de água gelada. Em relação ao material do produto $90 \%$ dos usuários responderam que é de fácil limpeza. Quanto aos aspectos ergonômicos do produto, 96\% dos entrevistados consideraram que o design é agradável, eficaz, seguro e recomendariam o produto. 90\% dos entrevistados nunca sofreram acidentes durante a realização da tarefa.

\section{CONCLUSÃO}

Após a realização da análise ergonômica do bebedouro constatou-se que ele é um produto silencioso, eficiente, elegante e com um excelente custo benefício. E foi possível descrever uma metodologia de avaliação para bens de consumo.

Independentemente de quais forem suas aplicações, acredita-se que a metodologia utilizada sirva para facilitar a interpretação do produto e sua utilização. Por meio dos resultados da pesquisa é possível observar que toda a sua interação com o produto gira em torno da análise.

O desenvolvimento deste estudo nos permitiu analisar que o bebedouro contém compressor com o poder de atingir a temperatura de água gelada desejada facilmente e facilita a limpeza por conter peças removíveis e encaixes precisos.

A interpretação desse produto é completamente atrelada às experiências vividas pelos usuários. É válido ressaltar que antes mesmo de haver o contato com o produto, é necessário saber da sua finalidade, qual é o seu objetivo e sua necessidade de utilizá-lo, pois pode-se levar em conta que o produto tem que ser utilizado de forma correta, para a sua dada tarefa. A execução precária do produto pode inferir em uma experiência negativa para o usuário.

Então, antes mesmo de procurá-lo, é recomendável que haja, de fato, uma necessidade para ele, já que por meio da necessidade o uso do produto possui um valor agregado maior, sendo assim, a sua interpretação proporcionará uma experiência de usabilidade mais adequada.

Diante do exposto, espera-se que este artigo tenha contribuído para mostrar uma análise fundamentada e para melhorias nas características ergonômicas do produto, promovendo um impacto no aumento da qualidade do produto. 
Consequentemente, será possível agregar valores ao produto em questão, satisfazendo ainda mais os seus usuários. 


\section{REFERÊNCIAS}

DANTAS, A. K. D.; SOUZA, C.; FERREIRA, M. S.; ANDRADE, M. A.; WATANABE, E. Qualidade microbiológica da água de bebedouros destinada ao consumo humano. Biociências, Unitau, v. 16, n. 2, 2010.

ESMALTEC ELETRODOMÉSTICOS S.A. Disponível em https//www.esmaltec.com.br. Acessado em 25/11/2016.

IIDA, I. Ergonomia: projeto e produção. 2. Ed. São Paulo: Blucher, 2005.

IIDA, I.; GUIMARÃES, L.B.M. Ergonomia: Projeto e Produção. 3. Ed. São Paulo: Blucher, 2016.

JORDAN, P. W. An Introduction to Usability. Londres: Taylor \& Francis Ltda., 1998.

KIM, J.;HAN, S. H.. A methodology for developing a usability index of consumer electronic products. International Journal of Industrial Ergonomics, v. 38, p. 333-345, 2008.

LÖBACH, B. Design industrial: bases para a configuração dos produtos industriais. São Paulo: E. Blücher, 2001.

MORAES, A. de; MONT'ALVÃO, C. Ergonomia: conceitos e aplicações. Teresópolis: 2AB. 4 ed., 2000.

MORAES, A. de; MONT'ALVÃO, C. Ergonomia: conceitos e aplicações. Teresópolis: 2AB. 4 ed., 2012.

PEZZARINO, R da S. Avaliação da Qualidade da Água Utilizada nos Distritos de Campos dos Goytacazes, RJ. Dissertação apresentada (Mestrado em Engenharia Ambiental) IFF Campus Campos-Centro, Campos dos oytacazes, RJ, 2010.

SABINO NETO, A.C.S. Melhoria de produtos de uso doméstico com a aplicação da ergonomia integrada ao processo de projeto. XXIV Encontro Nacional de Engenharia de Produção. Florianópolis, SC, 03 a 05 de novembro de 2004. 


\section{Capítulo 11}

\section{d.)}

\section{AVALIAÇÃO DA EFICIÊNCIA ENERGÉTICA EM EMPRESAS DO MEIO OESTE CATARINENSE}

Rian Lucas Franck

Cristiano Meneghini

Universidade do Oeste de Santa Catarina UNOESC

Universidade do Oeste de Santa Catarina UNOESC 
Resumo: A utilização de energia com melhor aproveitando dos recursos naturais faz as indústrias aumentarem o lucro e terem uma boa visibilidade. O presente estudo tem como objetivo apresentar resultados que foram observados em indústrias do meio oeste catarinense, analisando a eficiência energética. Em forma de questionário foram coletadas informações de 36 profissionais da indústria, do ramo metal mecânico, de alimentos, prestadoras de serviço, celulose e papel, calçados de segurança e armazenamento de grãos. Destas indústrias, $61 \%$ possuem um planejamento, com 0 intuito de obter eficiência energética, e 31\% não possui. Já se tratando do consumo de energia, a maioria (33\%) das indústrias utilizam entre 1000 a $2000 \mathrm{kWh}$ por mês. Dentro da indústria(entrevistadas) o setor que mais consome energia é de força motriz (61\%). E se tratando de resíduos $67 \%$ das indústrias(entrevistadas) não fazem reaproveitamento de resíduos. Os resultados obtidos foram bons, a eficiência energética está se estruturando, e com maior conscientização será possível um grande crescimento nesta área.

Palavra chaves: Eficiência energética, aproveitamento, planejamento, investimentos, indústria. 


\section{INTRODUÇÃO}

Buscar um modo eficiente para utilizar energia de forma racional, significa gerar a mesma quantidade de energia com menos recursos naturais. O uso de energia elétrica feito de maneira inadequada, ocasiona problemas econômicos e ambientais devido ao desperdício. Neste caso, é necessário realizar estudos de melhoria na eficiência energética com o intuito de sanar esses problemas e ter o máximo aproveitamento de energia possível, mantendo-se competitivo no mercado. (MARQUES, 007) A necessidade de uma gestão cada vez mais eficiente de recursos energéticos, é um reflexo do uso abusivo de energias não renováveis. Este consumo de insumos naturais é um reflexo do crescimento das indústrias, na qual podem provocar grandes danos ao meio ambiente, no seu processo produtivo. Segundo a EPE (Empresa de Pesquisa Energética) (2016), em 2015 a classe industrial foi responsável por $36,3 \%$ do consumo de energia no Brasil.

Existem programas que atuam nesta área, ajudando instalações industriais e comerciais de médio e grande porte, buscando otimização de sistemas motrizes (motores elétricos), instalações elétricas e mecânicas, acoplamentos, cargas acionadas e uso final, para que possam ter maior conservação de energia elétrica. (PROCEL, 2020)

Este trabalho foca no estudo da situação da eficiência energética nas empresas, por meio de observação dos métodos praticados em controles de produção, operações, máquinas e equipamentos, entre outros recursos.

\section{REVISÃO DE LITERATURA}

Segundo Leonelli (2007), a eficiência energética "consiste na relação entre a quantidade de energia empregada em uma atividade e aquela disponibilizada para sua realização", ou seja, aproveitar o máximo de uma potência empregada para determinado trabalho de forma que aumente a lucratividade ao mesmo tempo que ajuda o ambiente, buscando produzir mais gastando menos energia.

Este tema é discutido desde 1997, com o início do protocolo de Quioto, dando ênfase na necessidade de se obter um maior aproveitamento da energia já produzida, sendo que é um fato as fontes de energia estarem cada vez mais escassas e a demanda crescendo.

Pesquisas realizadas pela Empresa de Pesquisa Energética (EPE) mostram que $46 \%$ da energia do nosso país são para uso do setor industrial que, por sua vez, é responsável por grande parte de seu 
desperdício (SILVA, 2007). Em alguns casos são os motores elétricos mal dimensionados ou sobrecarregados que produzem maior energia reativa.

Estudos independentes mostram que $30 \%$ dos acionamentos de motores elétricos do setor industrial, ao operar em condições ideais de instalação, podem trabalhar de forma mais eficiente proporcionando uma economia de energia que chega a 50\% (SIEMENS, 2009).

Como forma de incentivo à eficiência energética, entrou em vigor no dia 24 de julho de 2000, a Lei n.으 9991/2000 que dispõe em seu Art. 10 o seguinte:

As concessionárias e permissionárias de serviços públicos de distribuição de energia elétrica ficam obrigadas a aplicar, anualmente, o montante de, no mínimo, setenta e cinco centésimos por cento de sua receita operacional líquida em pesquisa e desenvolvimento do setor elétrico e, no mínimo, vinte e cinco centésimos por cento em programas de eficiência energética no uso final. (BRASIL, 2000)

Para Abreu (2009), consultor de engenharia do setor industrial da Siemens no Brasil, "A gestão eficiente de energia e da manutenção é, em muitas situações, o que define a lucratividade de uma operação" sendo que atualmente a energia elétrica corresponde a um dos principais custos de uma organização.

Segundo o Balanço Energético Nacional de 2020, ano base 2019, a geração de energia foi expandida no Brasil, tendo um destaque para energia solar, fechando 2019 com um aumento de 37,6\% em relação ao ano anterior.

Com a crise de energia elétrica que aconteceu em 2001 no Brasil, foram criadas leis para a conservação e programas de incentivo a redução do consumo de energia. A primeira lei imposta referente a eficiência energética foi a lei $n^{\circ} 10295$ que estabeleceu níveis máximos de consumo específico de energia, ou mínimos de eficiência energética, para máquinas e aparelhos fabricados no país, com auxílio de indicadores técnicos pertinentes com o intuito de desenvolver a qualidade de energia no país (ENERGIA, 2011).

\subsection{IMPORTÂNCIA DE UMA INDÚSTRIA COM PLANEJAMENTO EM EFICIÊNCIA ENERGÉTICA}

A eficiência no uso de energia mostrou-se possibilitar o mesmo serviço, mas que poderia ser obtido com menor custo de energia e consequentemente com menores impactos ambientais, econômicos, sociais e culturais. (EPE, 2007) 
Diversas estratégias para uso eficiente de energia têm sido utilizadas no setor industrial, em vários países (Abdelaziz et al., 2011) desde a auditoria energética até a conscientização das pessoas em relação ao meio ambiente.

Os sistemas industriais de energia fazem uso de energia elétrica necessária para a conservação das matérias-primas e fabricação de produtos finais. Os sistemas incluem aquecimento direto e indireto, refrigeração, eletricidade, iluminação, sistemas de automação e eletricidade aos equipamentos e máquinas utilizadas.

\section{METODOLOGIA}

A pesquisa realizada caracteriza-se como uma pesquisa aplicada que, segundo Barros e Lehfeld (2000) consiste na utilização de dados práticos, para buscar soluções ao caso estudado. Quanto à abordagem dos dados, caracteriza-se como pesquisa quantitativa, no qual segundo Fonseca $(2002$, p. 20$)$ os resultados podem ser quantificados centrando-se na objetividade, com base na análise de dados, na qual recorre à linguagem matemática para descrever as variáveis.

Quanto aos objetivos, caracteriza-se como pesquisa de caráter exploratório, pois o levantamento de dados foi realizado através de entrevistas (GIL, 2006). Na pesquisa foi realizada uma avaliação sobre a forma que as indústrias estão tratando a eficiência energética. As perguntas buscaram avaliar o setor que possui mais consumo de energia referente ao tipo de produção; quantidade de resíduo produzido e se possui aproveitamento; quais estão sendo as dificuldades de implantar programas de eficiência energética e se o aproveitamento de energia está sendo uma estratégia para indústria

Após um estudo sobre assunto, observando suas vantagens, possíveis impactos e sua utilização nas indústrias, foram elaboradas algumas perguntas, para obter conhecimento a campo. Foram escolhidas algumas indústrias do meio oeste, de grande, médio e pequeno porte, selecionadas para preenchimento de um formulário, utilizando a plataforma google forms.

\section{RESULTADOS}

A seguir, apresenta-se resultados das pesquisas realizadas com as entrevistas estruturadas nas empresas. Os dados coletados são respostas de 36 indústrias do meio oeste catarinense, sendo 7 ramos de atuação industrial diferentes. 
Inicialmente, levantou-se o ramo de atuação da empresa, por segmento, como mostra a Figura1, onde $39 \%$ das empresas entrevistadas são do ramo metal mecânico, 22\% da indústria alimentícia, 14\% sendo prestadoras de serviço, $8 \%$ de celulose e papel e $3 \%$ para calçados de segurança e armazenamento de grãos. Vale lembrar que as empresas foram escolhidas de forma aleatória.

Figura 1: Ramo de atuação da indústria.

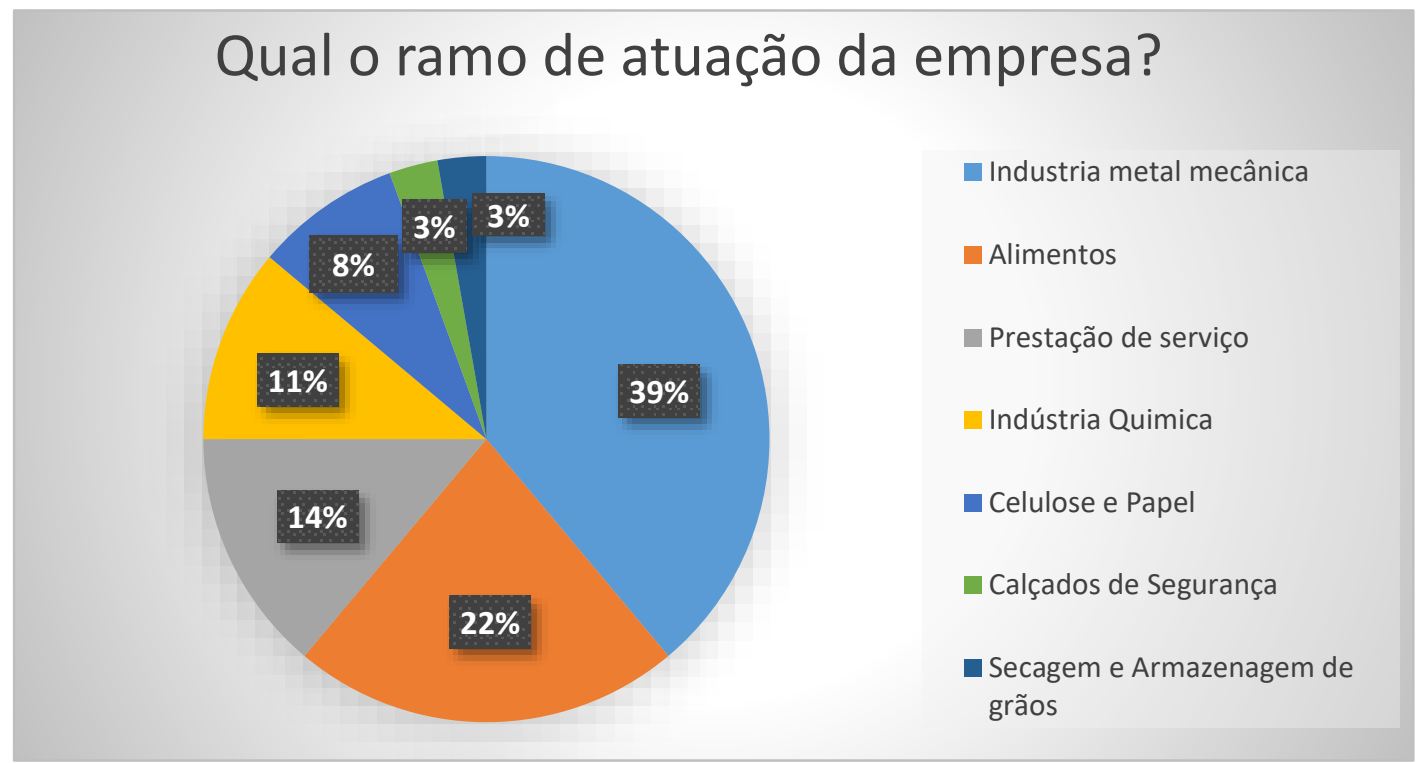

Fonte: Os Autores (2021)

Além disso, levantou-se quantia de energia que as empresas consomem mensalmente, como mostra a Figura 2. Das respostas obtidas, 33\% das empresas utilizam entre 1000 a 2000 kWh por mês, 22\% entre 500 a 1000 kW, 11\% tem um consumo de 2000 a 10000 kWh, 17\% tem uma utilização entre 0 a $500 \mathrm{kWh}$ e acima de $10000 \mathrm{kWh}$. Isso nos mostra que a maioria das empresas entrevistadas consome até 2000 kWh por mês, o que seria um baixo consumo energético, inviabilizando em muitas das vezes o investimento em eficiência energética. 
Figura 2: Quantidade de kWh consumidas mensalmente pelas empresas entrevistadas.

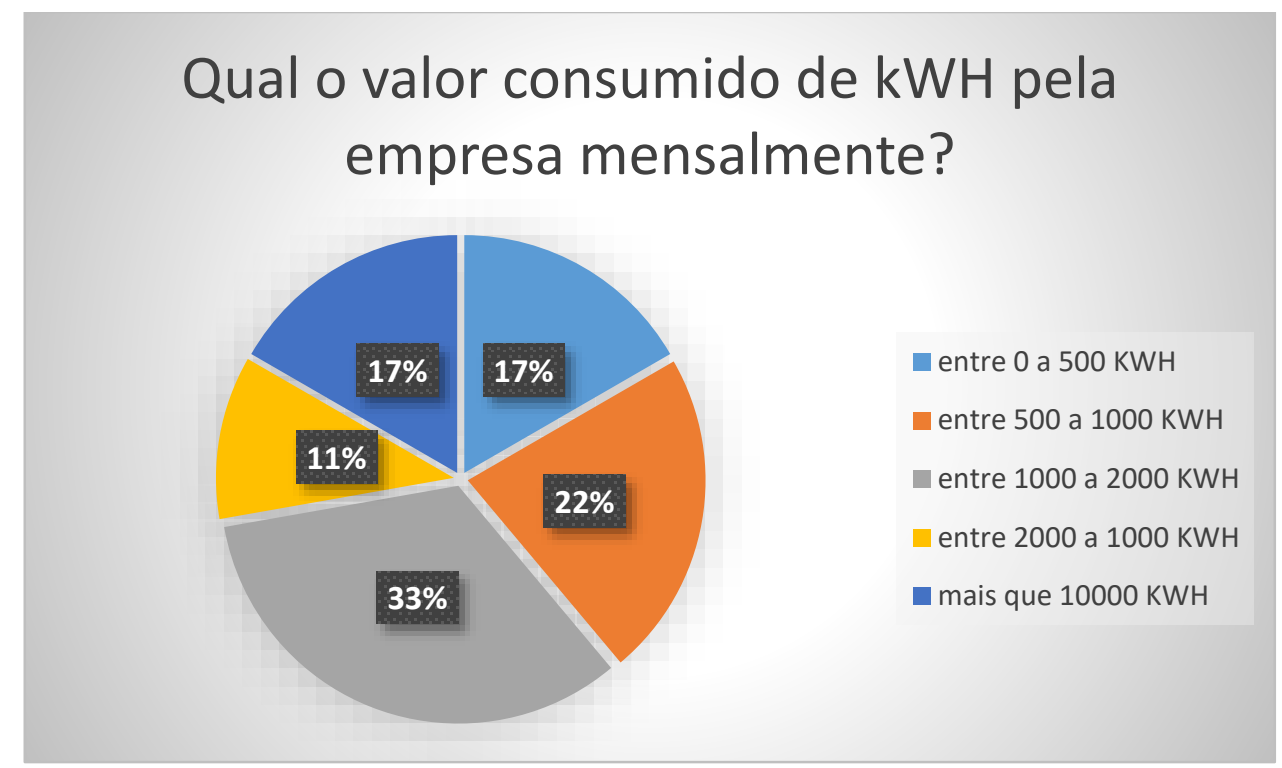

Fonte: Os Autores (2021).

E se tratando de planejamento, pode-se observar na Figura 3, que $61 \%$ das indústrias entrevistadas, buscam estratégia para obter eficiência energética, 39\% não possui estratégia. Esses números apontam que maioria das empresas entrevistadas possuem interesse em melhorias, tendo em vista o aumento custos para geração de energia, a eficiência energética acaba se tornando um recurso para se obter maior lucratividade.

Figura 3: A eficiência como estratégia.

\section{A Eficiência Energética faz parte das estratégias de sua empresa?}

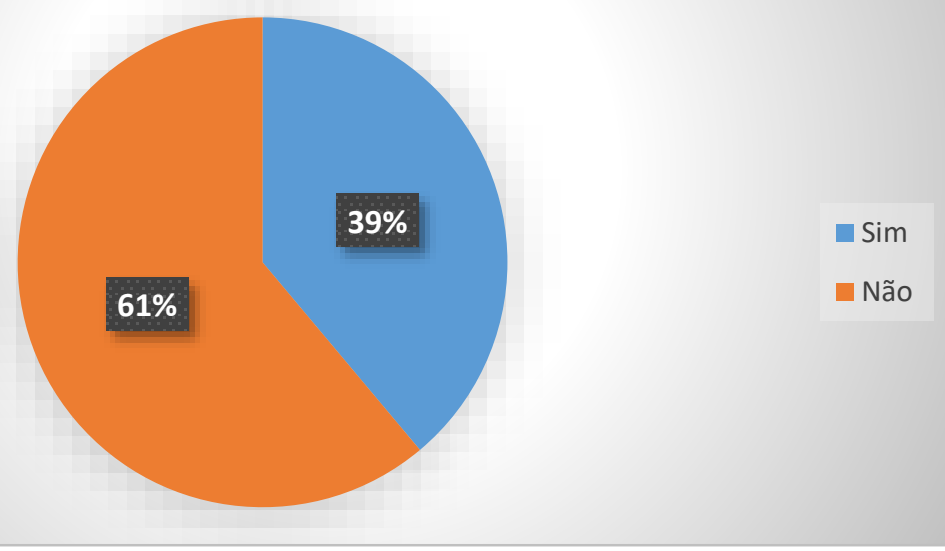

Fonte: Os Autores. (2021) 
Outro ponto abordado foi sobre o setor que mais gasta energia dentro da planta fabril. Cada indústria, possui uma forma de produção, variando a utilização da energia. De acordo com a Figura 4, 61\% das indústrias entrevistadas consideram a força motriz o setor que mais consome energia. Além disso, 17\% do consumo ocorre na refrigeração, $8 \%$ no aquecimento e iluminação e os $6 \%$ em processos eletroquímicos. O setor motriz é responsável pela maior parte do consumo de energia. No geral, toda indústria possui máquinas antigas, que foram projetadas antes das novas tecnologias, o que ocasiona um consumo de energia elevado e consequentemente o desperdício.

Figura 4: Setor que mais consome energia.

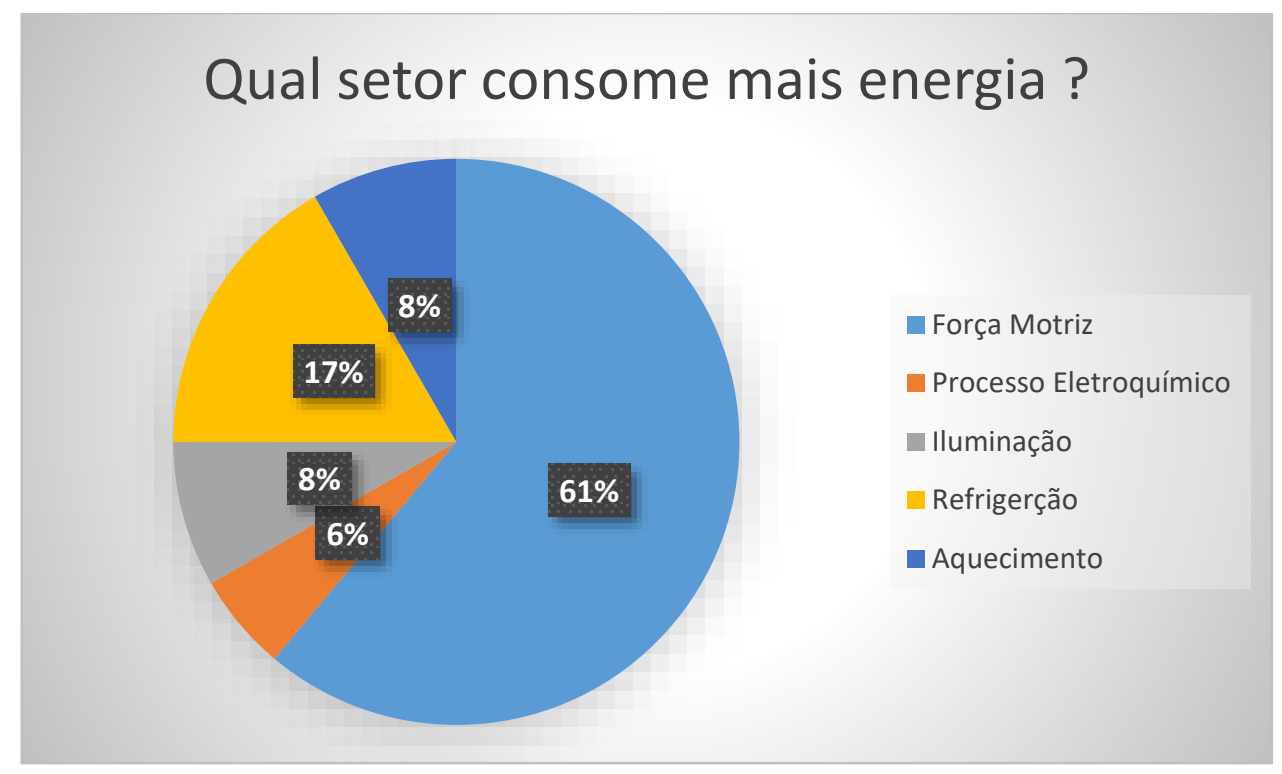

Fonte: Os Autores. (2021)

Com relação a questão de geração de resíduos, a Figura 5 mostra que 53\% das empresas produzem de 0 a 10 toneladas mensalmente, $28 \%$ de 20 a 30 toneladas, $16 \%$ entre de 10 a 20 toneladas e $3 \%$ produzem 30 a 40 toneladas, sendo a maioria de pequeno/médio porte. 
Figura 5: Toneladas de resíduos produzidos mensalmente.

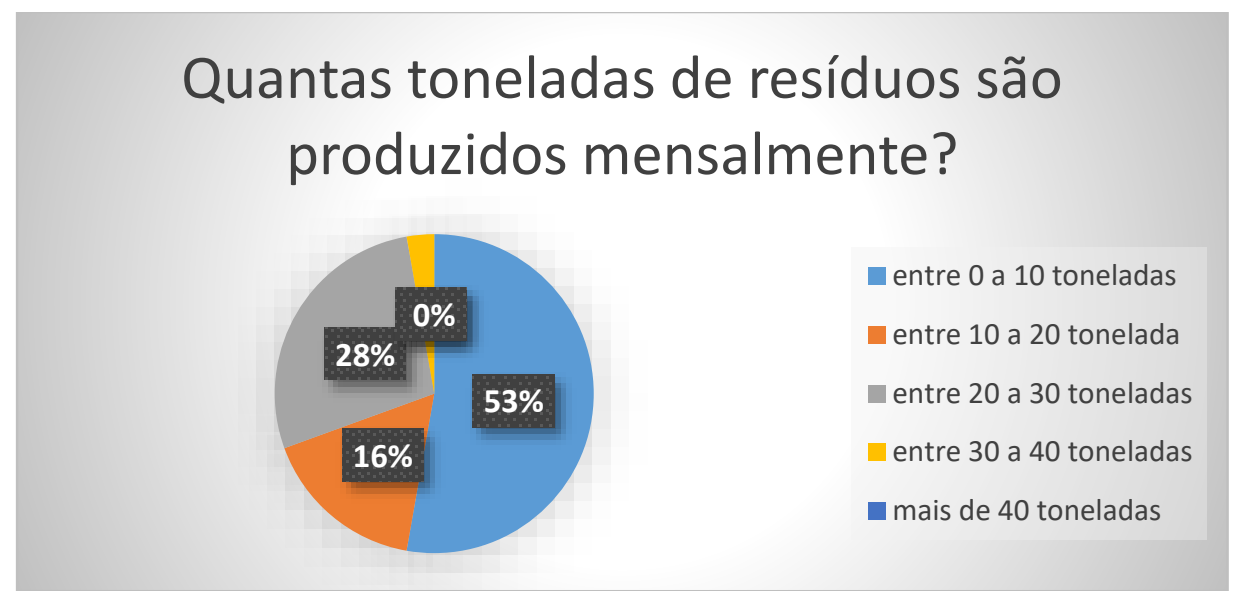

Fonte: Autores. (2021)

Sobre o destino destes resíduos, $67 \%$ não reaproveitam, $28 \%$ aproveitam através do biogás, e a incineração é feita por $5 \%$ das indústrias entrevistadas (Figura 6). 0 processo de aproveitamento de resíduos, em vezes se torna inviável pelo alto custo inicial de equipamentos destinado a essa atividade, neste caso tomam destinos diferentes, sendo depositados a céu aberto, trazendo prejuízos ao meio ambiente.

Figura 6: Como é feito o aproveitamento energético dos resíduos.

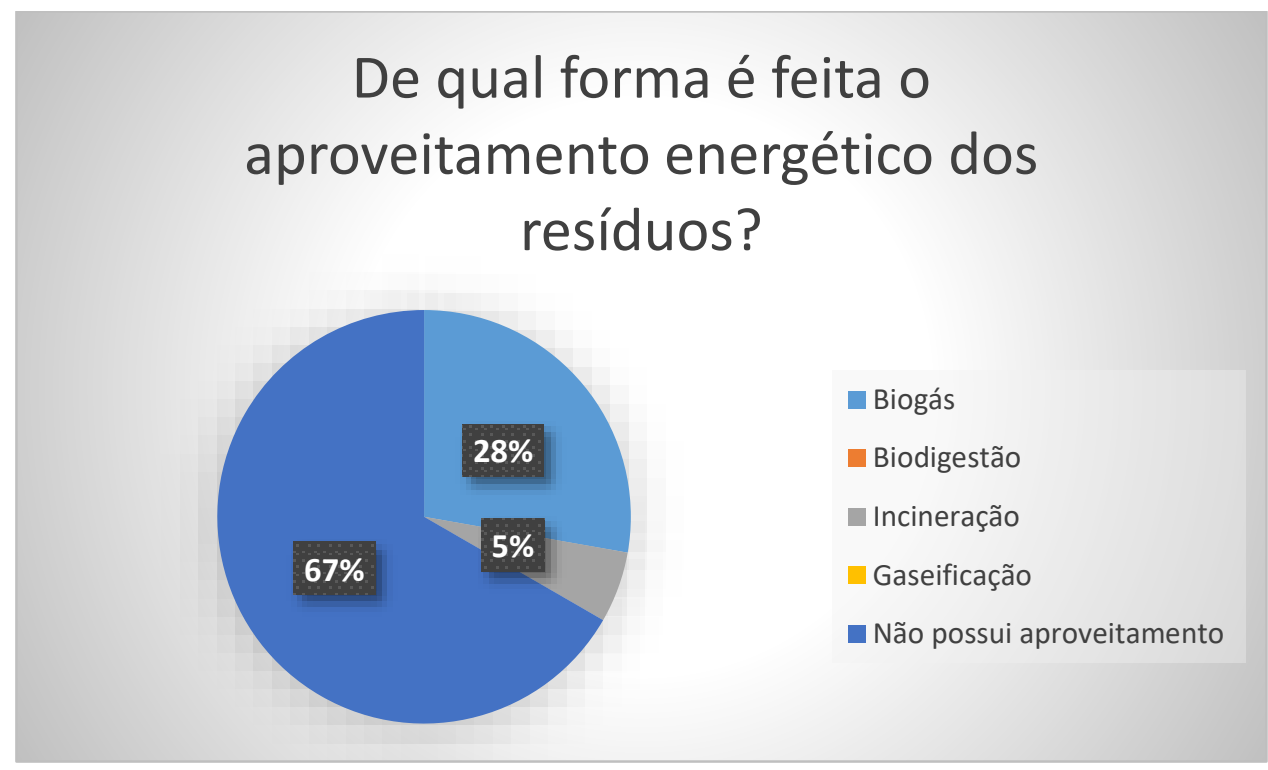

Fonte: O Autores (2021)

Visando reconhecer as dificuldades encontradas na implementação de medidas de eficiência energética, A Figura 7 mostra que $28 \%$ dizem não ter dificuldades, $25 \%$ responderam que a falta de conhecimento sobre as linhas de crédito impacta na implementação dessas medidas 19\% possuem 
dificuldades em conscientizar funcionários, 13,9\% tem falta de interesse neste tipo de inciativa, 13,9\% tem falta de interesse neste tipo de inciativa , $8 \%$ falta de recursos humanos especializados e $3 \%$ é por falta de recursos finaceiros e investimentos da diretoria.

Figura 7: Dificuldades para implementação de medidas de eficiência energética.

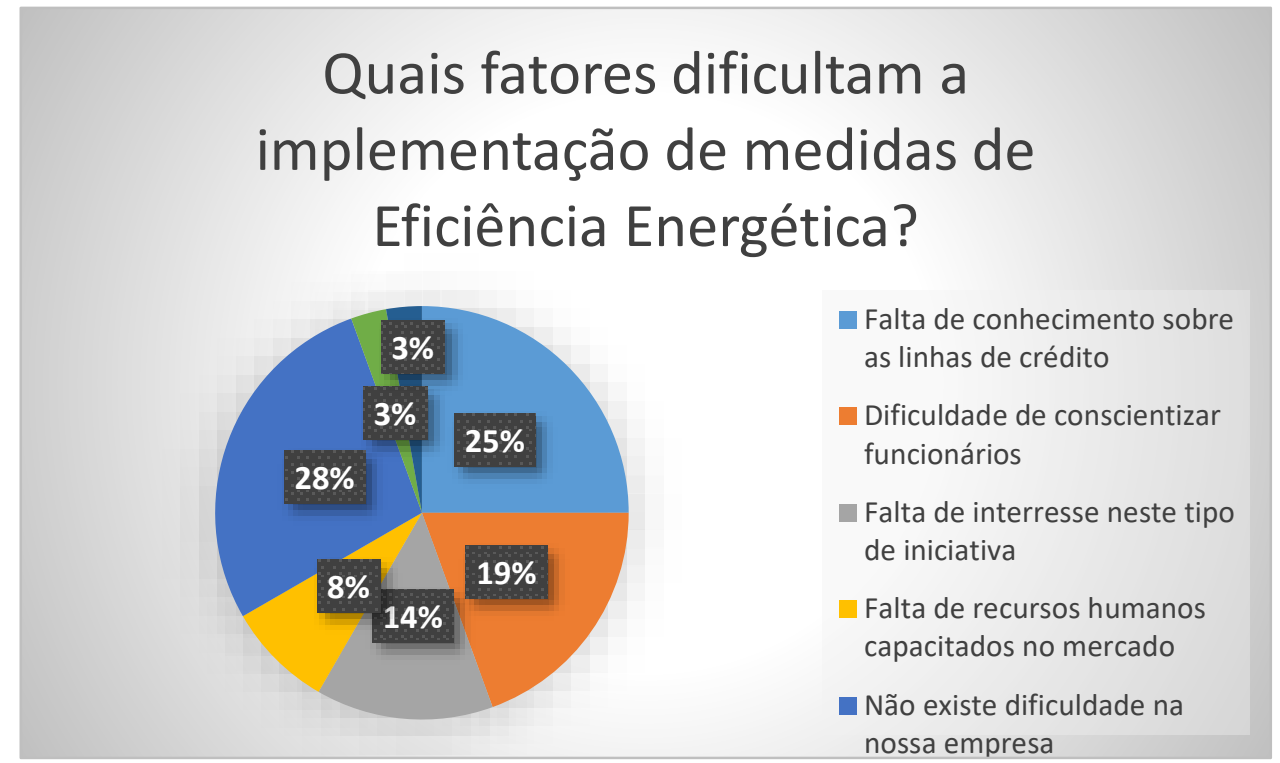

Fonte: O Autor. (2021)

Quando questionados sobre a opinião das indústrias, sobre qual alternativa possui maior relação com eficiência energética, como mostra na figura $8,25 \%$ aumento da competividade e produtividade da empresa, 33\% aumento do lucro, 20\% marketing, e $22 \%$ economia na fatura de energia. O lucro mostra a vantagem de implantar eficiência energética, sendo um incentivo para as indústrias. 
Figura 8: Alternativas que mais se relacionam com eficiência energética.

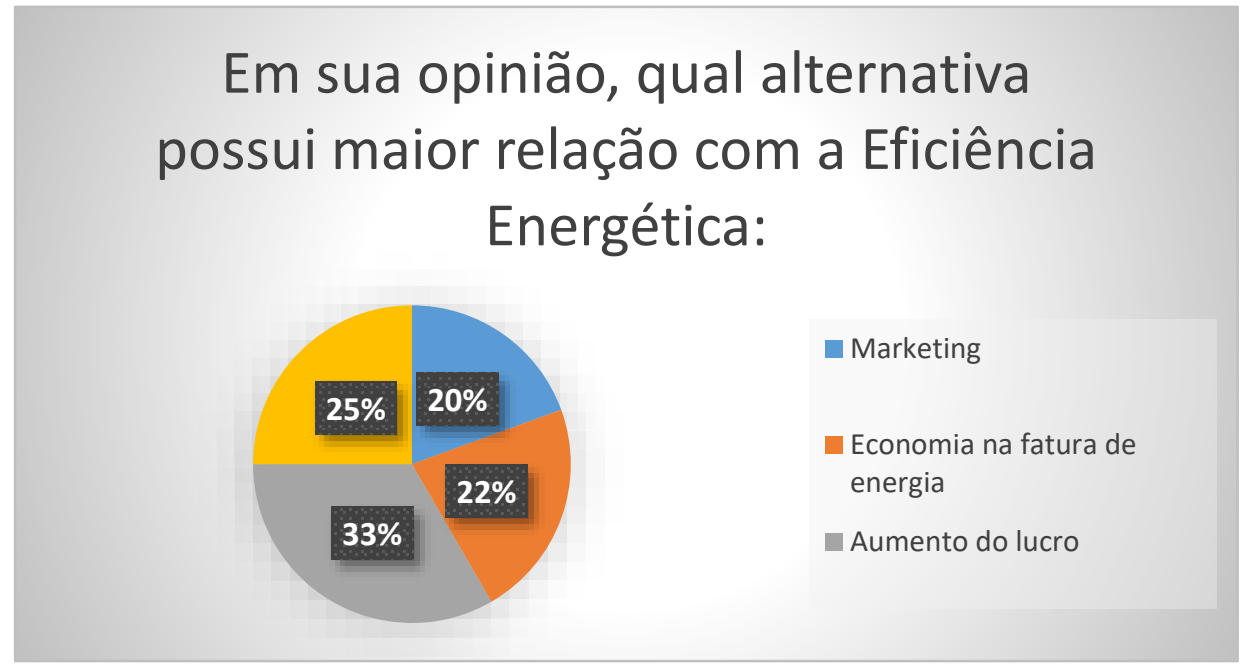

Fonte: Os Autores. (2021)

\section{CONCLUSÃO}

Com o crescimento da competitividade as empresas precisam buscar alternativas para se destacarem no mercado, por isso são necessárias estratégias e práticas para otimizar seus processos e resultados. A utilização da eficiência energética pode minimizar os custos e melhorar os resultados, surgindo melhorias tanto no sentido financeiro, sustentável, quanto na produção.

Com algumas correções no modo de se utilizar energia elétrica, pode-se garantir um aumento de sua eficiência energética, vida útil das instalações e dos motores e a redução da corrente reativa na rede elétrica. $\mathrm{O}$ ideal é que todas as empresas implantassem um plano energético bem elaborado, pois as principais práticas envolvem o combate ao desperdício de energia. Oferecendo um menor gasto de energia pelo consumidor e um maior rendimento e vida útil dos seus equipamentos

Analisando este consumo das indústrias o fato de melhorar a eficiência energética de um processo ou serviço, provoca a redução no consumo da energia primária, necessária para produção de determinado serviço. Esta ação ajuda a indústria tendo boa competividade e crescimento econômico seguro e sustentável.

Os resultados demonstram pouco aproveitamento dos resíduos, pois observa-se que não estão sendo realizados investimento em tecnologias nesse sentido. Desde 2010 existe a lei 12.305, que estabeleceu a PNRS (Política Nacional de Resíduos Sólidos), que cabe aos municípios a responsabilidade pelos resíduos gerados em seu território, essa lei visa a gestão integrada e o gerenciamento de resíduos 
sólidos, tendo um prazo de quatro anos para a disposição final ambientalmente adequada dos rejeitos, (PNRS).

Em uma gestão de qualidade é necessário buscar tecnologias para minimizar o consumo de energia em processos industriais, usando-a de forma inteligente para aumentar a competitividade do negócio e sua produtividade. 


\section{REFERÊNCIAS}

OLIVEIRA, S. L. Tratado de metodologia científica: Projetos de pesquisa, TGI, TCC, monografias, dissertações e teses. São Paulo: Pioneira, 1997.

BARROS A. J. S.; LEHFELD, N.A.S. Fundamentos de metodologia científica: um guia para iniciação cientifica. 2 ed. São Paulo: Pearson Education, 2000.

GIL, A. C. Como elaborar projetos de pesquisa. 4. ed. São Paulo: Atlas, 2006

MATTAR. F. N. Pesquisa de Marketing: edição compacta. São Paulo: Atlas, 1996

FONSECA, J. J. S. Metodologia da pesquisa científica. Fortaleza: UEC, 2002. Apostila.

EMPRESA DE PESQUISA ENERGÉTICA - EPE - Balanço Energético Nacional 2012- Eficiência Energética. Disponível em: https://ben.epe.gov.br/downloads/Relatorio_Final_BEN_2012.pdf. 2012. Acesso em: 10 de maio de 2021.

Silva, C. R. C. da, Deschamps, E. Péres, A. "Aplicativo computacional para simulação da obtenção de eficiência energética na indústria têxtil de felpudos", In Proc. of ICECE 2007, pp. 666-6700.

BRASIL. Lei no. 9991, de 24 de julho de 2000. Disponível em: Acesso em: 20 de outubro de 2020.

Ministério de Minas e Energia. (Fevereiro de 2015). Projeção da Demanda de Energia Elétrica. Acesso em 16 de Abril de 2020, disponível em Ministério de Minas e Energia: http://www.epe.gov.br/mercado/Documents/S\%C3\%A9rie\%20Estudos\%20de \%20Energia/20140203_1.pdf

Abdelaziz, E. A., Saidur, R., \& Mekhilef, S. (2011). A review on energy saving strategies in industrial sector. Renewable and Sustainable Energy Reviews, 15, 150-168. http:// dx.doi.org/10.1016/j.rser.10 mai. 2021.

Marques, M. C. S., Haddad, J., \& Martins, A. R. S. (Coord.). (2006). Conservação de energia: eficiência energética de equipamentos e instalações (3. ed.). Itajubá: Eletrobrás, Procel Educação, Unifei, Fupai.

Bezerra E. G. luis.(2019) Aproveitamento energético de resíduos sólidos urbanos https://politica.estadao.com.br/blogs/fausto-macedo/aproveitamento-energetico-de-residuossolidos-urbanos/ 